\title{
Mapa mínimo de relações do idoso: instrumento gráfico para identificar a rede de suporte social do idoso
}

\section{MARISA ACCIOLY RODRIGUES DA COSTA DOMINGUES}

Tese apresentada ao Programa de Pós-Graduação em Saúde Pública da Faculdade de Saúde Pública da Universidade de São Paulo para obtenção do título de Doutor em Saúde Pública.

Área de concentração: Serviços de Saúde Pública.

Orientadora: Profa. Dra. Alice Moreira Derntl

São Paulo 2004

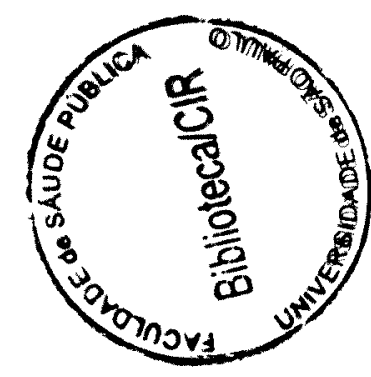


4564712005 doc

Autorizo, exclusivamente para fins acadêmicos e científicos, a reprodução total ou parcial desta tese, por processos fotocopiadores.

Assinatura:

Data: 


\section{DEDICATÓRIA}

A Maria de Lourdes, minha avó, uma rica lembrança que ilumina meu caminho.

A Glorinha e Reynaldo, meus pais.

Ao Bruno, Guilherme e Jeferson, os amores da minha vida. 


\section{AGRADECIMENTOS}

À Profa Alice Moreira Dernlt, pela competência e carinfo com que me acotheu desde o início da trajetória acadêmica.

À Profa Aracy Witt Spinola, que com seus ensinamentos me auxiliou na construção e condução da metodologia desta pesquisa.

Às amigas Ana Cristina Faro e Maria Helena Morgani de Almeida, pelo incentivo, carinfio e apoio.

Ao caro Profo Dr. Carlos Sluzǩi, que, à distância, contribuiu com seu conhecimento, sendo incansável em esclarecer minhas inquietudes.

Às colegas do Hospital das Clínicas, que não mediram esforços para que eu pudesse me dedicar a este trabalho. Meu especial agradecimento à Teca, Sandra Márcia e Nísia.

Aos juizes que participaram da pesquisa, pela colaboração, saber compartilhado e afeto.

Aos meus avaliadores, pelo olfar criterioso com que analisaram esse trabalfo. 


\section{RESUMO}

Domingues MA. Mapa mínimo de relações: instrumento gráfico para identificar a rede de suporte social do idoso. São Paulo; 2004. [Tese de Doutorado - Faculdade de Saúde Pública da USP].

O envelhecimento da população brasileira está impulsionando o Poder Público a criar alternativas que viabilizem a permanência do idoso na comunidade, otimizando suas capacidades e estimulando, dessa maneira, o exercício de sua cidadania. Para que se efetivem tais alternativas, faz-se necessária a identificação e posterior mobilização das pessoas que compõem sua rede de suporte social. Essa rede pode ser definida, segundo Sluzki, como o conjunto de pessoas que distingue um indivíduo da massa anônima da sociedade, tornando-o singular. Ela é constituída ao longo da vida, passando durante suas diversas fases por inúmeras alterações. Dispomos de alguns instrumentos para identificá-la, sendo um deles um instrumento gráfico, denominado de Mapa Mínimo de Relações. Esse instrumento foi formulado por Sluzki (1997), modificado e adaptado para a utilização com a população idosa por Domingues (2000), passando a denominar-se Mapa Mínimo de Relações do Idoso (MMRI). Nesta pesquisa, nosso objetivo foi validar consensualmente o MMRI. A metodologia da pesquisa previu a aplicação da técnica Delfos, definida como uma ferramenta de obtenção de consenso. Assim, submetemos o instrumento a dez profissionais denominados juízes, tendo como critério de seleção o reconhecido conhecimento no tema de estudo. O percentual de consenso definido, seguindo o referendado pela literatura, foi de $70 \%$ de opiniões convergentes para cada pergunta relativa ao MMRI, sendo a análise dos resultados efetuada com base na escala de Likert. As notas para cada questão do MMRI variaram de um (1) a cinco (5), denotando, respectivamente, total discordância da questão à sua total concordância. Os resultados mostraram que, após a segunda aplicação, apenas uma questão não obteve o percentual definido, tendo sido efetuada, apenas para esta, uma terceira aplicação. Após essa última aplicação, a partir das notas dadas pelos juízes e dos ajustes realizados segundo as sugestões recebidas, o instrumento obteve o consenso estabelecido para todas as perguntas, sendo o MMRI considerado validado consensualmente.

Descritores: apoio comunitário, idoso, mapa mínimo de relações, rede de suporte social, técnica Delfos, validação. 


\section{SUMMARY}

Domingues MA. Minimum map of relationship: a graphic instrument to identify the net of social support for the elderly. SP; 2004. [Doctoral Thesis - Public Health School of USP].

The aging of the Brazilian population is pushing the Public Authority to create alternatives to provide the permanence of the elderly in the community, developing their abilities and stimulating the practice of their citizenship. In order to carry out these alternatives, it is necessary to work on the identification and posterior mobilization of the people who are part of their social support. According to Sluzki, this net can be defined as a group of people that distinguishes an individual from the social anonymous masses, turning him a singular person. This net is established in a life time period and during its several phases it goes through many changes. We have some instruments to identify the net and one of them is a graphic instrument called the Minimum Map of Relationship. Sluzki (1997) created this instrument and it was modified and adapted by Domingues (2000), to be used with the elderly, and it is now named the Minimum Map of Relationship for the Elderly (MMRE). The aim of this research was to validate the MMRE. The methodology used in the research was the Delfos technique, which was defined as a tool to obtain the consensus. So, we have given the instrument to ten professionals, who were named the judges and the criterion to select them was based on their true knowledge about the theme studied. According to the literature, the percentage of the definite consensus was $70 \%$ of the convergent opinions on each question related to the MMRE. The analysis of the results was done based on the Likert scale. The grades for each question of the MMRE varied from one (1) to five (5), which respectively denoted the total disagreement with the question to the total agreement. The results have shown that after the second use of the instrument, only one question did not get a definite percentage, so this question was applied for the third time. After using the instrument for the last time, making the adjusts according to the suggestions received and from the grades given by the judges, the instrument got the established consensus on all the questions and the MMRE was considered valid consensually.

Descriptor: community support, the elderly, minimum map of relationship, net of social support, Delfos technique, validation. 


\section{ÍNDICE}

1 APRESENTAÇÃO 1

2 REFERENCIAL TEÓRICO 4

2.1 Envelhecimento da população brasileira 4

2.1.1 A legislação e o indivíduo idoso 6

2.2 Bases da atenção ao idoso

2.2.1 Bases formais de atenção ao idoso: a atuação interprofissional 7

2.2.1.1 O serviço social gerontológico 8

2.2.2 Bases informais de atenção ao idoso 8

2.2.2.1 Família 9

$\begin{array}{ll}\text { 2.2.2.2 Apoio comunitário } & 11\end{array}$

$\begin{array}{ll}\text { 2.2.2.3 Amigos } & 12\end{array}$

$\begin{array}{lr}\text { 2.2.2.4 Vizinhos } & 13\end{array}$

$\begin{array}{ll}2.2 .2 .5 \text { A rede de suporte social } & 13\end{array}$

2.3 Instrumentos de avaliação de suporte social $\quad 14$

$\begin{array}{ll}\text { 2.3.1 Instrumentos validados para avaliar suporte social } & 14\end{array}$

2.3.2 Instrumentos para avaliação de suporte social validados no Brasil $\quad 15$

2.3.3 Instrumento gráfico para avaliação de suporte social 16

$\begin{array}{ll}\text { 2.3.4 Base conceitual do Mapa Mínimo de Relações } & 17\end{array}$

2.3.5 Mapa Mínimo de Relações do Idoso: instrumento adaptado 18

2.4 A validação de instrumentos $\quad 22$

2.4.1 Validade 22

2.4.2 Tipos de validade $\quad 23$

2.5 Técnica Delfos: ferramenta para validação consensual de instrumentos 25

2.5.1 Aplicações da Técnica Delfos 27

2.5.2 Técnica Delfos: vantagens e desvantagens 28

3 OBJETIVO 29

4 MÉTODO 30

4.1 Justificativa do método utilizado $\quad 30$

4.2 Operacionalização do processo de validação consensual da pesquisa 30

$\begin{array}{ll}\text { 4.2.1 Critérios para seleção dos juízes } & 30\end{array}$ 
4.2.2.3 Fases de aplicação da pesquisa

4.3 Instrumento final $\quad 38$

5 APRESENTAÇÃO DOS RESULTADOS 46

5.1 Apresentação dos dados relativos às notas, sugestões e observações relativas às perguntas sobre dados de identificação, visita ou companhia e auxílio para serviços domésticos na $1^{\text {a }}$ aplicação do MMRI

5.2 Apresentação dos dados relativos às notas, sugestões e observações relativas às perguntas sobre auxílio para cuidados pessoais, auxílio financeiro e quanto à apresentação gráfica do instrumento na $1^{\mathrm{a}}$ aplicação do MMRI

5.3 Apresentação dos dados relativos à $1^{\mathrm{a}}$ aplicação do instrumento, segundo a Escala de Lickert

5.4 Apresentação dos dados relativos às notas, sugestões e observações relativas às perguntas sobre dados de identificação, visita, companhia e auxílio para serviços domésticos na $2^{\mathrm{a}}$ aplicação do MMRI

5.5 Apresentação dos dados relativos às notas, sugestões e observações relativas às perguntas sobre auxílio para cuidados pessoais, auxilio financeiro e quanto à apresentação gráfica do instrumento na $2^{\mathrm{a}}$ aplicação do MMRI

5.6 Apresentação dos dados relativos à $2^{\mathrm{a}}$ aplicação do instrumento, segundo a escala de Lickert

5.7 Apresentação dos dados relativos às notas, sugestões e observações relativas à pergunta sobre auxilio financeiro na $3^{\mathrm{a}}$ aplicação do MMRI

5.8 Apresentação dos dados relativos à $3^{\mathrm{a}}$ aplicação da questão relativa a auxílio financeiro do instrumento, segundo a escala de Lickert

6 APRESENTAÇÃO E ANÁLISE DOS ESCORES ATRIBUPIDOS PELOS JUIZZES

7 APRESENTAÇÃO E ANÁLISE DAS SUGESTÕES E OBSERVAÇÕES FORMULADAS PELOS JUÍZES

8 DISCUSSÃO DOS RESULTADOS 99

9 CONCLUSÃO 106

$\begin{array}{lr}\text { REFERENNCIAS } & 107\end{array}$ 


\section{ANEXOS}

Anexo 1 - Autorização do autor do mapa mínimo de relações para realização de sua adaptação e modificação

Anexo 2 - Parecer do Comitê de Ética em Pesquisa da Faculdade de Saúde Pública da Universidade de São Paulo - COEP

Anexo 3 - Carta convite pré-teste

Anexo 4 - Instrumento de coleta de dados: pré-teste

Anexo 5 - Termo de consentimento livre e esclarecido

Anexo $6-1^{\text {a }}$ Carta convite

Anexo 7 - Primeiro Questionário Delfos do MMRI

Anexo 8-2 $2^{\text {a }}$ arta convite

Anexo 9 - Segundo Questionário Delfos do MMRI

Anexo $10-3^{\mathrm{a}}$ Carta convite

Anexo 11 - Terceiro Questionário Delfos do MMRI

Anexo 12 - Considerações e parecer do autor do mapa mínimo de relações sobre o instrumento final 


\section{LISTA DE TABELAS}

Tabela 1: Médias, medianas, desvios padrão, valores mínimos e máximos observados dos escores relativos à clareza e pertinência da apresentação dos dados de identificação, nas duas respostas

Tabela 2: Médias, medianas, desvios padrão, valores mínimos e máximos observados dos escores atribuídos pelos juízes à pergunta 1 na primeira resposta e perguntas 1 e 2 na segunda resposta

Tabela 3: Médias, medianas, desvios padrão, valores mínimos e máximos observados dos escores atribuídos pelos juízes à pergunta 2 na primeira resposta e pergunta 3 na segunda resposta

Tabela 4: Médias, medianas, desvios padrão, valores mínimos e máximos observados dos escores atribuídos pelos juízes à pergunta 3 na primeira resposta e pergunta 4 na segunda resposta

Tabela 5: Médias, medianas, desvios padrão, valores mínimos e máximos observados dos escores atribuídos pelos juízes à pergunta 4 na primeira resposta e pergunta 5 na segunda e terceira respostas

Tabela 6: Médias, medianas, desvios padrão, valores mínimos e máximos observados dos escores atribuídos pelos juízes à apresentação gráfica do instrumento na primeira e na segunda resposta 


\section{LISTA DE FIGURAS}

Figura 1: Médias \pm erros padrão dos escores relativos à clareza e pertinência da apresentação dos dados de identificação, nas duas respostas

Figura 2: Médias \pm erros padrão dos escores atribuídos pelos juízes à pergunta 1 na primeira resposta e perguntas 1 e 2 na segunda resposta

Figura 3: Médias \pm erros padrão dos escores atribuídos pelos juízes à pergunta 2 na primeira resposta e pergunta 3 na segunda resposta

Figura 4: Médias \pm erros padrão dos escores atribuídos pelos juízes à pergunta 3 na primeira resposta e pergunta 4 na segunda resposta

Figura 5: Médias \pm erros padrão dos escores atribuídos pelos juízes à pergunta 4 na primeira resposta e pergunta 5 na segunda e terceira respostas

Figura 6: Médias \pm erros padrão dos escores atribuídos pelos juízes à apresentação gráfica do instrumento na primeira e na segunda resposta

Figura 7: Gráfico das freqüências observadas de cada categoria de sugestão observação para clareza da pergunta de identificação na primeira e segunda respostas

Figura 8: Gráfico das freqüências observadas de cada categoria de sugestão observação para pertinência da pergunta de identificação na primeira e segunda respostas

Figura 9: Gráfico das freqüências observadas de cada categoria de sugestão observação para clareza da pergunta 1 na primeira e perguntas 1 e 2 na segunda resposta

Figura 10: Gráfico das freqüências observadas de cada categoria de sugestão observação para pertinência da pergunta 1 na primeira resposta

Figura 11: Gráfico das freqüências observadas de cada categoria de sugestão observação para forma da pergunta 1 na primeira e perguntas 1 e 2 na segunda resposta

Figura 12: Gráfico das freqüências observadas de cada categoria de sugestão observação para clareza da pergunta 2 na primeira resposta e da pergunta 3 na segunda resposta

Figura 13: Gráfico das freqüências observadas de cada categoria de sugestão observação para pertinência da pergunta 2 na primeira resposta

Figura 14: Gráfico das freqüências observadas de cada categoria de sugestão observação para forma da pergunta 2 na primeira resposta e da pergunta 3 na segunda resposta 
Figura 15: Gráfico das frequiências observadas de cada categoria de sugestão observação para clareza da pergunta 3 na primeira resposta e da pergunta 4 na segunda resposta

Figura 16: Gráfico das freqüências observadas de cada categoria de sugestão observação para pertinência da pergunta 3 na primeira resposta

Figura 17: Gráfico das freqüências observadas de cada categoria de sugestão observação para forma da pergunta 3 na primeira resposta e da pergunta 4 na segunda resposta

Figura 18: Gráfico das freqüências observadas de cada categoria de sugestão observação para clareza da pergunta 4 na primeira resposta e da pergunta 5 na segunda e terceira respostas

Figura 19: Gráfico das freqüências observadas de cada categoria de sugestão observação para pertinência da pergunta 4 na primeira resposta

Figura 20: Gráfico das freqüências observadas de cada categoria de sugestão observação para forma da pergunta 4 na primeira resposta e da pergunta 5 na segunda e terceira respostas

Figura 21: Gráfico das freqüências observadas de cada categoria de sugestão observação para a pergunta 5 da primeira resposta e pergunta 6 na segunda resposta referentes à apresentação gráfica do instrumento 


\section{APRESENTAÇÃo}

A inserção num contexto social é essencial para a sobrevivência do ser humano durante todo o seu percurso de vida. Tal fato decorre do processo de socialização inerente à existência do homem, distinguindo-o, dessa forma, dos demais seres vivos. Temos a família como nosso primeiro vínculo. É ela que nos nutre, fornece apoio, conforta e protege. É, pois, nossa primeira referência como ser social.

Posteriormente, novos relacionamentos vão se desenvolvendo, novos contatos e vínculos são estabelecidos. Surgem os colegas, sendo que alguns se tornarão amigos, os vizinhos e outras pessoas da comunidade em que estamos inseridos. $\mathrm{E}$ assim seguimos incluindo e excluindo pessoas em nosso rol de relações.

Todo esse elenco de pessoas tem como tarefa precípua participar do processo de construção da nossa identidade, dando-nos singularidade. Além desse atributo, essa rede exerce, ao longo da vida, inúmeras funções. Umas nos acompanham durante toda a nossa trajetória: dar e receber atenção, carinho, conforto. Outras se alteram ou se alternam, dependendo da necessidade: os auxílios para cuidados, para serviços e outros, uma vez que as demandas para cada fase de vida sofrem mudanças (GARCIA-PINTOS 1997; SLUZKI 1997; NERI 2001; RAMOS M 2002).

As solicitações da infância não são as mesmas da adolescência, que posteriormente são substituídas pelas da idade adulta, chegando finalmente às necessidades dos indivíduos idosos.

De acordo com SHANAS, são principalmente as gerações mais jovens, auxiliadas por pessoas da comunidade, as responsáveis por prover tais cuidados aos progenitores (SHANAS 1979).

É nesse momento que o apoio comunitário e familiar - sistema informal de suporte social - articulado com os profissionais - sistema formal de atenção constitui um recurso ímpar para a qualidade da atenção ao idoso (NERI 2001). 
Conhecer esse elenco de relações, identificá-lo, valorizá-lo e mobilizá-lo é, portanto, de suma importância. Para tanto, faz-se mister a aplicação de instrumentos capazes de avaliá-lo, dando-lhe visibilidade.

Um instrumento concebido para essa finalidade é o Mapa Mínimo de Relações. Ele foi elaborado por SLUZKI, médico-psiquiatra argentino radicado nos Estados Unidos em 1995, sendo traduzido para o português por meio de um livro publicado no Brasil com a anuência do autor em 1997 (SLUZKI 1997). Uma grande vantagem desse instrumento sobre os outros é sua formulação gráfica. Esse atributo torna fácil a visualização das relações avaliadas a partir de questões objetivas relativas às atividades primordiais para a permanência do idoso na comunidade. Reúne, assim, evidentes vantagens operacionais para o cotidiano da assistência dos serviços de saúde.

Nosso interesse no estudo do Mapa Mínimo de Relações segue um percurso iniciado no mestrado, onde o adaptamos para a utilização com pessoas idosas, dando origem ao Mapa Mínimo de Relações do Idoso (MMRI). Para tanto, obtivemos a autorização do autor, como descrito no Anexo 1.

Neste trabalho cumprimos mais uma etapa fundamental do processo para viabilizar sua recomendação: validamos consensualmente o MMRI, modificado e adaptado por DOMINGUES (2000).

O caráter multidisciplinar do instrumento permite sua utilização tanto pelo trabalhador da área social, quanto pelos demais profissionais que compõem uma equipe multidisciplinar. Por se tratar de um instrumento gráfico, como já mencionado, deve ser orientado sobre sua forma de aplicação, para que sua difusão e socialização sejam facilitadas permitindo a comparação de dados de maneira rápida e precisa, o que viabiliza a verificação das alterações de tamanho, composição, funções, freqüência de contatos de uma rede de suporte social, conforme a demanda de cada caso ou de cada serviço. É, pois, o MMRI um meio de avaliação e de planejamento de intervenção competente para o assistente social, em especial no âmbito da saúde pública.

Pretendemos, então, com base nos resultados deste trabalho e pelas vantagens acima mencionadas, recomendar a utilização do MMRI nos vários níveis de atenção ao idoso: programa de saúde da família, unidades básicas de saúde, hospitais e 
centros de referência e de convivência, como um recurso apropriado para o planejamento de serviços e para a formulação de políticas públicas que viabilizem, em consonância com o Estatuto do Idoso, identificar formas que possibilitem a permanência do idoso na e com a comunidade.

Esta pesquisa tem a seguinte divisão: um capítulo inicial, no qual traçamos o perfil dos tipos de apoio que o indivíduo pode obter, trazendo à luz os referenciais acerca dos auxílios familiares, comunitários e o apoio formal. Num segundo momento, apresentamos conceitos sobre os diversos meios de obtenção de validade de um dado instrumento e sobre a técnica utilizada nesta pesquisa. A seguir, discorremos acerca do percurso realizado para a obtenção do consenso entre os juízes e o discutimos à luz das sugestões emanadas por esses especialistas. Explicitamos as limitações do MMRI, quando discutimos os resultados da aplicação da técnica de obtenção de consenso, e finalizamos com as conclusões dessa trajetória. 


\section{REFERENCIAL TEÓRICO}

\subsection{Envelhecimento da população brasileira}

A partir da década de 60 , observou-se no Brasil, a exemplo do que já ocorria em países desenvolvidos, uma alteração na base da pirâmide populacional.

Data dessa década o aumento significativo de idosos frente à população geral. Esse evento, denominado de envelhecimento populacional, ampliou a expectativa de vida ao nascer, traduzindo-se numa maior longevidade da população brasileira, por decorrência de vários fatores:

- diminuição nas taxas de fecundidade e natalidade;

- melhoria das condições de saneamento básico que viabilizaram o diagnóstico e o tratamento precoce de doenças crônico-degenarativas;

- controle de epidemias;

- cura de doenças infecto-contagiosas (CHAIMOWICZ 1997).

Para termos uma idéia da dimensão deste fato, no Brasil, na década de 40, cerca de $4 \%$ da população total era de sexagenários. No ano 2000 , essa taxa se aproximou a $9 \%$, representando 15 milhões de pessoas com 60 anos ou mais (IBGE citado por PAPALÉO NETTO 2002).

Por esses dados, segundo a Organização Mundial de Saúde (OMS), citada por CAMARANO, o Brasil pode ser considerado um país estruturalmente envelhecido, ou seja, possui uma taxa de idosos superior a $7 \%$ de indivíduos idosos (CAMARANO e col. 2002).

Assim sendo, o país, que até bem pouco tempo era considerado um país de jovens, rapidamente alterou seu aspecto para um país de longevos, de cabelos brancos (VERAS 1994, 2001).

Observa-se também uma franca expansão de idosos mais idosos, indivíduos com 80 anos e mais, contribuindo para o envelhecimento dentro desse próprio segmento etário (COSTA e col. 2000, p. 36). 
Segundo COSTA, os fatores que explicam esse aumento são "a diminuição da mortalidade nas faixas etárias anteriores; a maior esperança de vida dos octogenários, elevando o contingente nonagenário e aumentando, por conseguinte, o número de centenários" (COSTA e col. 2000, p. 36).

De acordo com a Organização Mundial de Saúde (OMS), citada por CARVALHO e GARCIA (2003), o contingente de idosos em todo o mundo era de 27 milhões nos anos 70, no final da década de 90 passou a ser de 66 milhões, estimando-se para 2050 quase dois bilhões de indivíduos nessa etapa do ciclo de vida.

Quanto à interface entre o envelhecimento e a demanda por cuidados, a Pesquisa Nacional de Amostra por Domicílio (PNAD) de 2001, citada por COSTA e col. (2002) registra os seguintes dados: $5 \%$ das pessoas com 65 anos tem algum grau de incapacidade funcional. Aos 85 anos esse percentual sobe para 46, ou seja, a cada cem idosos quarenta e seis apresentam alguma incapacidade.

É importante ressaltar que tais dados não expressam o tipo de incapacidade nem seu estado. Sendo assim, nesse contingente, temos tanto aqueles que apresentam pequenas dificuldades para suas atividades cotidianas, como os que são severamente incapacitados. De qualquer modo, em maior ou menor grau, eles demonstram a necessidade de estarmos atentos para as fontes potenciais de apoio informal, pois, o declínio da capacidade funcional ${ }^{1}$ é algo que freqüentemente tende a avançar com o passar dos anos, exigindo, inúmeras vezes, que o idoso venha a necessitar de auxílios para as suas atividades cotidianas.

As ações destinadas aos diversos segmentos etários de idosos devem, portanto, ser distintas, atendendo às necessidades e peculiaridades apresentadas, que, como mostram os dados do IBGE, tendem a aumentar nos grupos de pessoas mais velhas, o que o torna mais vulnerável e potencialmente mais predisposto a necessitar

1 Capacidade funcional é a habilidade que 0 indivíduo possui para se adaptar às alterações próprias do envelhecimento. Em outras palavras, é a capacidade que ele tem para gerir e executar atividades da sua vida. Sendo assim, pode ser definida como as habilidades necessárias para a realização de atividades do dia-a-dia, como autocuidar-se, executar as tarefas da casa, fazer compras, autodeterminar-se. Essas habilidades podem ser dimensionadas por escalas de avaliações funcionais (Katz citado por RAMOS 2002, p. 75). 
e a solicitar uma maior freqüência nas atividades realizadas pela sua rede de relações (LEMOS e MEDEIROS 2002; SAAD 2003).

Essa situação, reitera COSTA, exige Políticas Públicas que valorizem o apoio familiar e comunitário como estratégia para a manutenção do idoso na comunidade (COSTA e col. 2000).

\subsubsection{A legislação e o indivíduo idoso}

O envelhecimento da população brasileira e a pressão dos movimentos sociais dos que militam na área do envelhecimento pressionaram o Poder Público sobre a premência da implementação de políticas especificas de atenção ao idoso. Surge assim, a partir da promulgação da Constituição de 1988, a Política Nacional do Idoso, datando tal política de 1994 (BRASIL 1988; BRASIL 1994).

Posteriormente, em 1999, foi promulgada a Política Nacional de Saúde do Idoso, com o objetivo de atender à necessidade do setor saúde. Tal política, em vigor até o momento, tem como diretriz básica a formulação de programas que enfocam a manutenção e a melhoria da capacidade funcional do idoso, visando prevenir, recuperar e reabilitar a saúde, possibilitando sua permanência na comunidade e o exercício de sua cidadania (BRASIL 1999).

Corroborando os ditames legais acima descritos, foi promulgada em setembro de 2003, tendo sanção presidencial em $1^{\circ}$ de outubro do mesmo ano, a Lei 10.741 , que dispõe sobre o Estatuto do Idoso (BRASIL 2003).

A promulgação desse Estatuto reflete o esforço dos órgãos representativos dos idosos, assegurando que as políticas públicas sejam efetivamente cumpridas, contemplando os mais variados aspectos de sua vida. Abrange, dessa maneira, desde os direitos fundamentais do indivíduo, até o estabelecimento de penas para crimes cometidos contra as pessoas idosas. 


\subsection{Bases da atenção ao idoso}

Como bases de atenção ao idoso, entendemos os fundamentos que norteiam as políticas públicas dirigidas a esse segmento etário. São elas as responsáveis pelas estratégias que tratam da manutenção do indivíduo em seu habitat, com recursos da própria comunidade, provendo-o do apoio social necessário (ANDER-EGG 1996; GRIEP, DORA, FAERSTEIN e LOPES 2003).

Tais bases podem ser formais, quando constituídas pelas instituições de atenção ao idoso, ou informais, quando compostas pelas pessoas da rede de relações do idoso (AYÉNDEZ 1994; SLUZKI 1997; NERI 2001;CALDAS 2003).

\subsubsection{Bases formais de atenção ao idoso: a atuação interprofissional}

A atenção formal ao idoso compreende tanto a atuação individual de cada profissional quanto à ação de uma equipe interprofissional. Isso se dá pela singularidade inerente a essa fase de vida. Ao contrário das etapas anteriores do ciclo de vida, esta é marcada por inúmeras particularidades. Se na infầncia, na adolescência e mesmo na idade adulta jovem temos padrões que identificam um grupo, o mesmo não ocorre com relação à velhice. Nela, a história de vida de cada indivíduo, sua aquisição cultural, social e afetiva, seu histórico familiar e os papéis sociais desempenhados ao longo da vida permitem que duas pessoas com a mesma idade cronológica tenham histórias, estilos de vida e necessidades completamente diversas, tornando-as, dessa maneira, extremamente distintas. Essa individuação demanda, portanto, o olhar de várias áreas de conhecimento, ou seja, a reunião de muitas disciplinas, e, mais que isso, um olhar onde esses saberes se agreguem, gerando um novo saber, mais amplo e de domínio coletivo, resultando na expressão interdisciplinar do conhecimento (PAPALÉO NETTO 2002).

O trabalho interdisciplinar, segundo a Organização Pan-Americana de Saúde (OPAS), citada por JACOB FILHO (1998), é essencial para a promoção da saúde no envelhecimento, pois é "muito dificil que apenas um profissional, com todo o seu conhecimento e possibilidades terapêuticas, reúna condição para o atendimento ao idoso" (p. 12). 


\subsubsection{O Serviço Social Gerontológico}

Como partícipe das áreas de atenção ao idoso, o Serviço Social atua como membro de uma equipe interdisciplinar, realizando suas intervenções tanto em nível individual, como grupal ou comunitário. $\mathrm{O}$ trabalho social gerontológico caracterizase por diferentes tarefas, atividades e serviços, e tem por objetivo conhecer o meio social onde vive o idoso, identificando sua rede de suporte social, auxiliando-o em suas necessidades básicas numa ótica sistêmica, integrando ou reintegrando o indivíduo à sua comunidade. Dessa maneira, a atuação do profissional se dá na dimensão social dos problemas de saúde. A partir desse olhar, nascem as funções desempenhadas por esses profissionais, algumas essenciais que se prestam ao fortalecimento do suporte social ao idoso e à sua rede de relações, dentre as quais podemos citar:

- identificar os problemas, trabalhando com um enfoque assistencial, reabilitador e de re-inserção social;

- orientar os usuários para que busquem resolver seus próprios problemas;

- atuar como facilitador das relações sociais entre os usuários e a instituição;

- promover e fortalecer a organização de grupos de apoio e auto-ajuda;

- participar de equipes na coordenação de serviços de orientação social e auxílio ou ajuda em domicílio.

Em todas as funções mencionadas, verifica-se a necessidade de instrumentos ajustados para a área social, capazes de fornecer dados para que o profissional planeje sua intervenção com base nas características, necessidades e peculiaridades do idoso, do seu grupo familiar e comunitário (MARTINELLI 1987; GUTTMANN 1994; ANDER-EGG 1996; VILELLA, KALCKMANN e PESOTO, 2002).

\subsubsection{Bases informais de atenção ao idoso}

Como base informal de atenção, entendemos todo o aparato que se constitui para prestar auxílio ao idoso, oriundo de seu círculo de relações pessoais. 
Os expoentes mais expressivos, segundo a literatura pesquisada, emanam da família, dos amigos e da comunidade (DABAS 1993; AYÉNDEZ 1994; ANDRADE, ESPIN, GONZALEZ e VEA-BAYORRE 2001).

Passamos a descrever a seguir cada um desses recursos.

\subsubsection{Família}

A sociedade contemporânea protagoniza alterações significativas nas relações de parentesco e no surgimento de novas formas de família. Em épocas anteriores, elas eram maiores, mais numerosas. Freqüentemente residiam num mesmo local, compartilhando, muitas vezes, da mesma atividade laboral. Tamanha proximidade promovia um maior envolvimento de seus membros, favorecendo que um deles cuidasse de seu progenitor, quando este viesse a necessitar (PRADO 2002).

O apoio familiar, todavia, passou por alterações, admitindo novos arranjos decorrentes da queda da natalidade, vigente na sociedade brasileira atual. Em algumas regiões mais desenvolvidas, por exemplo, temos taxas de nascimento próximas ou abaixo da de reposição, expressa, segundo a OMS, por 2,1 filhos por casal, tendo, portanto, famílias com poucos membros.

Em contrapartida, em regiões mais carentes, as dificuldades quanto ao apoio familiar ao idoso são de outra natureza. Os jovens, com muita freqüência, migram para regiões mais promissoras, deixando seus progenitores sem retaguarda familiar (CAMARANO 2003).

Em ambos os casos, o apoio comunitário emerge como uma alternativa às necessidades do idoso. Continua sendo a família, contudo, tanto a nuclear, composta pelos descendentes, quanto a ampliada, que abarca, além dos componentes da família nuclear, seus ascendentes, colaterais e agregados, como, por exemplo, cunhado, nora, genro etc., o vínculo primeiro a ser acionado quando da instalação de alguma incapacidade no idoso (AQUINO e CABRAL 2002; ERBOLATO 2002; RODRIGUES e RAUTH 2002).

Temos ainda outros arranjos, hoje entendidos como família. 
Entende-se por família estendida e modificada aquela que, apesar de seus membros residirem em casas separadas, muito distantes, ou mesmo em outras localidades, mantêm entre si o relacionamento ativo, ocorrendo a intimidade à distância ${ }^{2}$.

Já a família modificada é aquela que agrega, além dos parentes, os amigos íntimos e os vizinhos (NEUGARTEN 1970; AYÉNDEZ 1994; GARCIA PINTOS 1997; NERI 2001; RODRIGUES e RAUTH 2002).

De todos esses tipos de arranjos familiares ainda, contudo, é a família nuclear a grande provedora de cuidados.

São, segundo DABAS (1993), as atitudes sociais e culturalmente definidas que atuam sobre as gerações, fazendo com que as mais novas forneçam o suporte necessário a seus idosos. Na maioria das vezes, é uma atitude com forte caráter afetivo e retributivo, que conta com uma diversidade de colaborações e trocas entre idosos e seus filhos adultos, num contexto de solidariedade intergeracional e maturidade filial (SALVAREZZA 1996; RODRIGUES e RAUTH 2002; CALDAS 2003).

Para HERR e WEAKLAND (1979), a família ocupa importante papel na vida do idoso como fator potencializador para manejar os problemas de saúde no envelhecimento. Sugerem os autores que, na avaliação clínica do idoso, seja incluída uma avaliação global, inserindo tanto a família nuclear, como a estendida e a modificada. Ainda quanto ao envolvimento familiar, SHANAS (1979) e DABAS (1993) apontam a família como o suporte principal para que se evite a institucionalização de idosos mais fragilizados.

Apesar da maior possibilidade de os idosos dependerem do apoio familiar à medida que envelhecem, não é a dependência o principal fator nas relações do idosofamília. $O$ fator preponderante dessa relação é, acima de tudo, a interdependência, pois, se em muitas ocasiões os idosos recebem ajuda, em outras, provêem assistência e auxílio aos filhos, netos e bisnetos (SHANAS 1979; DOBROF 1997).

\footnotetext{
${ }^{2} \mathrm{O}$ termo intimidade à distância foi descrito por Rosenmayr e Köeiskeis em 1965, citado por RODRIGUES e RAUTH (2002), para designar a comunicação e o contato mantidos entre pais e filhos por telefonemas ou visitas.
} 


\subsubsection{Apoio comunitário}

Com a diminuição da quantidade de membros das famílias, fenômeno observado tanto nos países desenvolvidos quanto nos em desenvolvimento, a participação comunitária, por meio dos amigos e vizinhos, é cada vez mais usual como um fator primordial para o desenvolvimento de políticas e programas de atenção ao idoso. Segundo alguns pesquisadores brasileiros, o cuidado ofertado pela família e pela comunidade, entendido como cuidado informal, em parceria com o disponibilizado pelos profissionais, cuidado formal, constituem um importante suporte aos idosos dependentes (NERI 2001; PERRACINI, NAJAS e BILTON 2002; SAYEG e MESQUITA 2002; KARSCH 2003).

As ações desencadeadas por essa parceria se efetivam por meio de orientações, esclarecimentos e informações, que viabilizam propostas terapêuticas direcionadas à promoção da saúde do idoso, objetivando sua permanência na comunidade. Sem o apoio formal, essa rede informal de apoio ou de suporte social sente-se desamparada, sem condições de responder às demandas necessárias. É importante ressaltar que, como o processo de envelhecimento não é uniforme, os indivíduos podem atingir idades avançadas em boas condições físicas, produzindo, porém, diferentes demandas à sua rede de suporte social, que não seja para a prestação de cuidados especificamente com a saúde (DOMINGUES 2000; LEMOS e MEDEIROS 2002).

Para atender às várias demandas do idoso, do mais dependente, ao independente, a Organização Pan-Americana de Saúde no ano de 1998, em sua $25^{\mathrm{a}}$ Conferência Sanitária recomendou três tipos de programas de atenção ao idoso, com os seguintes objetivos:

- envolvimento com a comunidade para evitar a institucionalização de pessoas debilitadas;

- incentivo à atenção primária de saúde, evitando a hospitalização;

- programas que estimulem a autonomia dos idosos (OPAS 1998). 


\subsubsection{Amigos}

Segundo ERBOLATO (2002, p. 962), a categoria amigos pode ser definida como:

(...) relacionamentos voluntários, predominantemente entre iguais, resultado do livre-arbítrio: escolhe-se a quem dar e de quem receber afeição, sem obrigatoriedade. São escolhidos com base em semelhanças entre as pessoas (gênero, etnia, status, escolaridade e faixa etária) e por apresentarem atributos considerados desejáveis como lealdade, confiança, valores e interesses comuns.

Para AYÉNDEZ (1995, p. 364), amigos são "pessoas que mantêm relações afetivas que podem predispor a vários tipos de assistência: companhia, compartilhar confidências, prover serviços ou auxílio em atividades cotidianas".

Quanto às funções desempenhadas, nota-se uma diferença entre as realizadas por familiares e pelos amigos. Estes, mais freqüentemente, desempenham um papel pequeno na ajuda ao idoso mais fragilizado, incidindo a maior demanda de cuidados relativos aos cuidados pessoais à família, principalmente às filhas (KARSCH 2003, 1998). Os amigos costumam, mais corriqueiramente, executar atividades instrumentais, tais como fazer compras, auxiliar nas atividades domésticas ou fazer companhia (AYÉNDEZ 1994).

Para ERBOLATO, isso se deve a dois fatores:

- os amigos geralmente são contemporâneos, apresentando, muitas vezes, as mesmas dificuldades ou limitações, o que dificulta a provisão de cuidados;

- na amizade tudo é voluntário, não havendo assim nenhum caráter de obrigação, como nos vínculos familiares. A provisão fornecida é, portanto, sempre facultativa. Apesar dessas limitações, os amigos representam um vínculo extremamente significativo para o idoso, no que tange à manutenção de sentimentos de bem-estar, diminuindo a solidão e promovendo interação (ERBOLATO 2002, p. 962). 


\subsubsection{Vizinhos}

Com a diminuição das famílias, os amigos, os vizinhos e as demais pessoas da comunidade constituem uma rede eficiente e ativa, funcionando como um dos pilares da rede de suporte social do indivíduo. Por toda sua importância, como instância que pode facilitar a permanência do idoso no seu meio, essa rede deve ser valorizada e mobilizada, pois é a base dos programas de Prevenção e Promoção de um envelhecimento saudável (OPAS 1998; OPAS 2002).

As relações estabelecidas com os vizinhos podem limitar-se à assistência para serviços ou apoio instrumental, não necessariamente de caráter afetivo, como na amizade (AYÉNDEZ 1994).

Quanto a esses relacionamentos, segundo ERBOLATO (2002, p. 963), "são relacionamentos marcados pela proximidade geográfica e contato freqüente, duas características que podem ser associadas à provisão de auxílio, de informações e de pequenas tarefas, muitas vezes imprescindíveis para aqueles que têm mobilidade limitada".

\subsubsection{A rede de suporte social}

Os conceitos de cibernética e posteriormente de teoria sistêmica foram os grandes alicerces para o estudo das redes de relações. Tais redes podem ser entendidas como os vínculos construídos ao longo da vida, nos quais podem imperar o aspecto afetivo, retributivo ou de obrigação (SEIXAS 1992; SLUZKI 1997; RAPIZO 1998).

Outro termo utilizado para conceituar esse fenômeno é o Comboio Social. De acordo com ERBOLATO (2002), tal comboio pode ser definido pelo conjunto de pessoas de uma rede de relações que fornece ao indivíduo o suporte e/ou o apoio necessários para conduzir as situações decorrentes de sua vida. Lembra a autora ainda que, à medida que o indivíduo envelhece, o mesmo ocorre com os que o rodeiam, tanto nas relações familiares, quanto nas comunitárias, havendo, desse modo, um envelhecimento estrutural de sua rede de relacionamentos. Nessa perspectiva, corroborando com dados apontados por GARCIA PINTOS, há uma tendência a se evitar o estigma de idoso-problema, pois, entende-se o envelhecimento 
como um fato que acomete todo o núcleo relacional do indivíduo. Nessa perspectiva, todos envelhecem juntos. A rede possui, dessa maneira, uma característica jovem, madura ou envelhecida, de acordo com a idade, os papéis sociais desempenhados e as demandas de seus componentes (GARCIA PINTOS 1997).

Quanto ao conceito de rede de suporte social, SLUZKI $(1997$, p. 41) a define como "o conjunto de pessoas significativas para o indivíduo, que o distingue da massa anônima da sociedade”.

Para NERI (2001, p. 110), é "o conjunto hierarquizado de pessoas que mantêm entre si laços típicos das relações de dar e receber”. Essa rede, diz ainda a autora, existe ao longo de todo o ciclo vital do indivíduo, atendendo à motivação básica do ser humano de interação.

No envelhecimento, porém, esses relacionamentos tendem a se contrair. Isso se deve basicamente a dois fatores: morte de seus componentes e diminuição de oportunidades para efetivar novos contatos. Mesmo assim, os vínculos que se mantêm são de grande intensidade, tornando sua atuação bastante efetiva (CARSTENSEN 1995; SLUZKI 1997).

\subsection{Instrumentos de avaliação de suporte social}

\subsubsection{Instrumentos validados para avaliar suporte social}

Dispomos de instrumentos que nos permitem identificar e avaliar a composição, as funções e a qualidade do suporte social recebido, segundo a percepção do indivíduo. Esses instrumentos não se destinam exclusivamente à população idosa, sendo alguns validados. Dentre esses, LIN e col. (1979) desenvolveram uma escala de medida de suporte social, relacionada ao limiar de estresse ocasionado pela doença.

NORBECK, LINDSEY e CARRIERI (1981) criaram um questionário, o Questionário de Suporte Social Norbeck (NSSQ) para verificar os atributos de uma rede de suporte social, com questões que avaliam tanto a estrutura, quanto o aspecto relacional da rede. 
SARANSON, LEVINE e SARANSON (1983) elaboraram o Questionário de Suporte Social (SSQ), que tem como objetivo avaliar a disponibilidade e a satisfação do respondente quanto ao suporte social recebido, pesquisando as propriedades psicométricas, o nível de satisfação e o elo com a saúde.

Ainda com relação a escalas validadas, em MCDOWELL e NEWELL (1996) encontramos a descrição da escala de Mc Farlante A 1981 (SRS), da bateria de Rand e da escala de Martin Katz.

A escala de Mc Farlante A 1981 (SRS) mede a extensão das redes individuais de relacionamento. Foi criada para a utilização em amostras gerais da população. Conceitua suporte social como um amortecedor contra doenças. É composta de aspectos qualitativos e quantitativos dos integrantes da rede de relações que auxiliam o indivíduo a tratar os eventos estressantes relativos basicamente à saúde.

A bateria de Rand (Rand Corporation 1978) registra a interação social e os recursos para suporte social. Não avalia as questões subjetivas do suporte social.

A escala de Martin Katz (escala de Katz 1963) foi desenvolvida para medir o ajustamento social de pacientes psiquiátricos em seguimento de tratamento.

O fato de muitas dessas escalas terem sido validadas há um periodo razoável de tempo, só lhes confere maior confiabilidade, como veremos no capítulo relativo à validação de instrumentos. Por esse motivo, optamos por descrevê-las.

\subsubsection{Instrumentos para avaliação de suporte social validados no Brasil}

A avaliação de suporte social conta, segundo a revisão realizada, com os instrumentos já validados a seguir comentados.

O Questionário de Suporte Social (SSQ), de SARANSON, LEVINE e SARANSON (1983) foi adaptado para a realidade brasileira por MATSUKURA, MARTURANO e OISHI em 2002. Tal instrumento não foi especificamente formulado para avaliar o suporte social de idosos, sendo a pesquisa que o validou realizada com mães de crianças com idades variando entre 0 e 12 anos, moradoras em diferentes bairros da cidade de São Carlos, interior do Estado de São Paulo. Os resultados do estudo de adaptação e fidedignidade do SSQ indicaram uma 
fidedignidade teste-reteste aceitável, bem como um alto nível de consistência interna do instrumento.

Em outro estudo, GRIEP, CHOR, FAERSTEIN e LOPES (2003) verificaram a confiabilidade teste-reteste no estudo Pró-Saúde, utilizando a escala de apoio social do Medical Outcomes Study (MOS). Esse instrumento, além de conter as principais dimensões funcionais de apoio social descritas na literatura, apresentou propriedades psicométricas adequadas.

DUARTE (2000) realizou uma pesquisa que avalia a funcionalidade familiar enquanto recurso, ou como um fator estressor, denominado de "apgar" da família. O estudo foi realizado apenas com sujeitos idosos de um serviço ambulatorial do Hospital das Clínicas da Universidade de São Paulo (HC/USP). Os resultados indicaram uma fidedignidade teste-reteste aceitável, bem como um alto nível de consistência interna do instrumento.

Temos ainda alguns instrumentos validados a partir da utilização da técnica Delfos, descrita do capítulo 2.5.1 deste trabalho.

\subsubsection{Instrumento gráfico para avaliação de suporte social}

Para avaliar o suporte social recebido pelo indivíduo, além dos questionários e escalas já mencionados, existe também um instrumento gráfico denominado de Mapa Mínimo de Relações, que identifica os relacionamentos significativos para o indivíduo, delimitando sua rede de suporte social (SLUZKI 1997). Tal instrumento foi concebido por Carlos Sluzki, médico psiquiatra, argentino, radicado nos Estados Unidos. Sua grande vantagem em relação aos outros tipos de instrumento de avaliação social se deve ao fato de ser um instrumento gráfico. Tal atributo lhe permite a fácil identificação e visualização dos vínculos significativos mencionados. Outra vantagem em relação aos demais é poder ser aplicado por qualquer profissional de equipe multidisciplinar, desde que capacitado para tanto, sendo a sua utilização, por esses motivos, extremamente pertinente para a área social e de saúde, em especial para a saúde pública, em que a aplicação de instrumentos de fácil visualização favorecem a disseminação da informação com maior presteza e rapidez, atributos de grande relevância, quando se atende um vasto número de indivíduos. 
Para o ajustamento do instrumento à população idosa, ele foi adaptado e modificado por (DOMINGUES 2000), tendo, para tanto, a autorização do autor (Anexo 1).

\subsubsection{Base conceitual do Mapa Mínimo de Relações}

O princípio fundamental de um mapa mínimo de relações é a sociometria, área de pesquisa da psicologia social desenvolvida por Jacob Levi MORENO. Esse pesquisador cunhou o conceito de psicologia geográfica com o propósito de esboçar um mapa de relações - do tipo "quem conhece quem" - para ser aplicado a grupos e comunidades. A expressão dos dados coletados é apresentada por meio de um mapa de relações, ou seja, de um sociograma. Nele, os relacionamentos significativos são dispostos em vários círculos que simbolizam os diversos graus de proximidade de relacionamento (MORENO 1967; GIL 1995; SLUZKI 1997).

Para que se configure um mapa de relações, dois conceitos são fundamentais: a proximidade do relacionamento, segundo a percepção do pesquisado, e a freqüência com que o contato ocorre.

O conceito de proximidade de relacionamento tem uma característica eminentemente qualitativa, preponderando os aspectos afetivos que envolvem seu estabelecimento (Kahn e Antonucci 1980, citados por NERI 2002, p. 111).

Segundo DOBROF (1997), pesquisadora americana, nos EUA, tal proximidade promove a intimidade à distância entre o conjunto da rede de relações. Quanto a esse aspecto, a autora faz a seguinte colocação:

...mesmo quando os pais idosos e seus filhos estão geograficamente distantes, o contato é mantido através de telefonemas regulares e freqüentemente, cartas, presentes e visitas periódicas; e, além disso, embora a distância física realmente impeça a disponibilidade destes filhos e de suas famílias no dia-a-dia das pessoas idosas, ainda se pode contar com eles para certos tipos de assistência (DOBROF 1997, p. 55). 
Já a freqüência de contatos permite identificar o aspecto instrumental do vínculo estabelecido, a efetivação do apoio recebido. Essa avaliação é sobremaneira importante na análise da rede de relações dos idosos, principalmente daqueles cuja capacidade funcional encontra-se diminuída, requerendo auxílio para as atividades cotidianas (ROLES, CURIEL, GARCIA, COLES, MEDRANO e GONZALEZ 2000). De acordo com BOWLING, a percepção do apoio social, mensurada pela freqüência de contatos, está diretamente relacionada ao grau com que as relações interpessoais correspondem a certas funções, ou seja, diz respeito aos recursos disponibilizados em situação de necessidade (BOWLING 1997; DUE e col. 1999; GRIEP, COHR, FAERSTEIN e LOPES 2003).

\subsubsection{Mapa Mínimo de Relações do Idoso: instrumento adaptado}

Desenvolveu-se na Faculdade de Saúde Pública da Universidade de São Paulo (2000) uma pesquisa sobre Mapa Mínimo de Relações, adaptando-o e modificando-o para identificar a Rede de Suporte Social do Idoso (RSSI). A conclusão desse estudo deu origem a um instrumento, denominado Mapa Mínimo de Relações do Idoso (MMRI). Tal instrumento tem por objetivo conhecer a composição, a proximidade das relações e as funções desempenhadas pelos componentes dessa rede (DOMINGUES, 2000).

As modificações que foram efetivadas se fizeram necessárias para que a avaliação da RSSI propiciasse ao profissional um modo preciso e ágil de identificar os componentes dessa rede, possibilitando assim efetivar intervenções mais adequadas (DOMINGUES 2000).

No instrumento original, SLUZKI propõe perguntas para avaliar os aspectos afetivos das relações, sendo o registro das respostas efetuado pela marcação de um ponto no quadrante da relação mencionada, associado ao círculo que denota maior ou menor proximidade do indivíduo.

As modificações realizadas no instrumento, com a anuência do autor do modelo original (anexo 1), foram efetivadas principalmente quanto às perguntas formuladas e à forma de registrar as respostas no mapa mínimo de relações. 
Dessa forma, os ajustes efetuados quanto às perguntas exigiram a formulação de questões objetivas relativas às atividades cotidianas executadas pelo idoso, as quais são registradas no MMRI no quadrante que identifica um dos quatro tipos de relacionamento pesquisados: amigos, família, relações com a comunidade e relações com o sistema de saúde, e no círculo que denota a proximidade de relacionamento.

Já para o registro das respostas no MMRI, a adaptação se deu pela elaboração de abreviações para identificar as relações desenvolvidas nos quadrantes de relações familiares e comunitárias. Tais modificações possibilitaram distinguir os graus de parentesco referente às relações familiares e os recursos comunitários mais usuais, percebidos como significativos. Para DOMINGUES (2000), as adaptações e modificações foram necessárias para que se pudesse identificar a diversidade desses relacionamentos, que são de extrema importância para o planejamento da intervenção assistencial ao idoso, no âmbito social e da saúde, principalmente àquele mais fragilizado.

Nos demais quadrantes, a forma de registro de resposta não sofreu alteração, seguindo o efetuado no instrumento original.

Quanto ao gráfico do mapa mínimo de relações, a única modificação realizada foi a inserção de um quadrante para identificar as relações significativas desenvolvidas com os profissionais de saúde, por entendermos que esses são parte da rede de relações do idoso, substituindo o quadrante originalmente formulado por SLUZKI para registrar as relações desenvolvidas em ambiente de trabalho.

No MMRI, essas relações são registradas no quadrante de amigos, pois o desejado com o instrumento é identificar o quão significativo é o relacionamento para o idoso, podendo esse ser fruto do ambiente de trabalho ou de outros cenários por ele freqüentados.

No quadro abaixo apresentamos a comparação do Mapa Mínimo de Relações original formulado por SLUZKI com o adaptado e modificado por DOMINGUES (2000), descrevendo os aspectos relevantes das alterações formuladas, bem como as justificativas para tais mudanças. Posteriormente, apresentamos também, os instrumentos gráficos: o original (fig. A) e o modificado (fig. B). 


\begin{tabular}{|c|c|}
\hline $\begin{array}{c}\text { Mapa Mínimo Original } \\
\text { (SLUZKI 1997) }\end{array}$ & $\begin{array}{l}\text { Mapa Mínimo adaptado } \\
\text { (DOMINGUES 2000) }\end{array}$ \\
\hline $\begin{array}{l}\text { Caracteristicas estruturais } \\
\text { - tamanho } \\
\text { - composição } \\
\text { - densidade } \\
\text { - proximidade de relacionamento } \\
\text { - homogeneidade ou heterogeneidade } \\
\text { Caracteristicas funcionais: } \\
\text { - companhia social } \\
\text { - apoio emocional } \\
\text { - guia cognitivo e de conselhos } \\
\text { - regulação social } \\
\text { - ajuda material e de serviços }\end{array}$ & $\begin{array}{l}\text { Características estruturais: } \\
\text { - mantida } \\
\text { - mantida } \\
\text { - não pesquisada } \\
\text { - mantida } \\
\text { - não pesquisada } \\
\text { Características funcionais: } \\
\text { - mantida } \\
\text { - não pesquisada } \\
\text { - não pesquisada } \\
\text { - não pesquisada } \\
\text { - mantida, detalhada em três funç̋̃es: } \\
\text { - auxilio para serviços domésticos } \\
\text { - auxílio para cuidados pessoais } \\
\text { - auxilio financeiro }\end{array}$ \\
\hline $\begin{array}{l}\text { Perguntas para configurar a Rede de suporte } \\
\text { social: }\end{array}$ & $\begin{array}{l}\text { Perguntas para configurar a Rede de suporte } \\
\text { social: }\end{array}$ \\
\hline 1) Quem são as pessoas importantes da sua vida? & 1) Quem $\alpha(a)$ visita ou the faz companhia? \\
\hline $\begin{array}{l}\text { 2) Com quem você encontrou ou conversou nesta última } \\
\text { semana? } \\
\text { 3) Quando você está com vontade de visitar alguém para } \\
\text { quem você liga? }\end{array}$ & $\begin{array}{l}\text { 2) Se } \alpha \text { (a) senhor(a) precisar de auxílio para serviços } \\
\text { domésticos, quem } \alpha \text { (a) auxiliaria? } \\
\text { 3) Se } \alpha(a) \text { senhor(a) precisar de auxilio para cuidados pessoais, } \\
\text { quem } o(a) \text { auxiliaria? }\end{array}$ \\
\hline $\begin{array}{l}\text { 3) Quem é ou poderia ser um ombro amigo para você chorar? } \\
\text { 4) Com quem você se encontra regularmente? }\end{array}$ & $\begin{array}{l}\text { 4) Se } \alpha(a) \text { senhor(a) precisar de auxílio financeiro, a quem } \alpha(a) \\
\text { senhor(a) recorreria? }\end{array}$ \\
\hline Maneira de Identificar a proximidade: & Maneira de identificar a proximidade: \\
\hline $\begin{array}{l}1^{\circ} \text { círculo: relação próxima } \\
2^{\circ} \text { círculo: relação intermediárla } \\
3^{\circ} \text { círculo: relação distante }\end{array}$ & $\begin{array}{l}1^{\circ} \text { círculo: relação próxima } \\
2^{\circ} \text { circulo: relação intermedlárla } \\
3^{\circ} \text { círculo: relação distante }\end{array}$ \\
\hline $\begin{array}{l}\text { Maneira de proceder ao registro das respostas } \\
\text { no mapa mínimo de relaçóes: }\end{array}$ & $\begin{array}{l}\text { Maneira de proceder ao registro das respostas no } \\
\text { mapa mínimo de relaçóes: }\end{array}$ \\
\hline $\begin{array}{l}\text { Proceder às perguntas e colocar um ponto no circulo ao qual } \\
\text { pertence a relação citada como significativa para a idosa. }\end{array}$ & $\begin{array}{l}\text { O registro das respostas é efetuado colocando-se no Mapa } \\
\text { Minimo, o número da pergunta formulada e a abreviação } \\
\text { correspondente, aos quadrantes de relaçóes famillares e } \\
\text { comunidade. Os relacionamentos relativos a amigos ou } \\
\text { profissionais do sistema de saúde, deverăo ser registrados } \\
\text { apenas por melo de um ponto. Procede-se então as perguntas, } \\
\text { informando ao entrevistado que cada uma delas tem três } \\
\text { possibilidades de resposta representando cada uma delas, uma } \\
\text { proximidade de relacionamento. informa-se ainda que as } \\
\text { perguntas que tiverem mais de um integrante com a mesma } \\
\text { proximidade devem ser mencionados com a conjunçăo "e". A } \\
\text { pausa entre uma resposta e outra, significa a inclusão da última } \\
\text { pessoa mencionada, num círculo mais distante. }\end{array}$ \\
\hline $\begin{array}{l}\text { Tamanho da Rede de suporte social: } \\
\text { - Pequena } \\
\text { - Média } \\
\text { - Grande }\end{array}$ & $\begin{array}{l}\text { Tamanho da Rede de suporte social: } \\
\text { - Pequena } \\
\text { - Média } \\
\text { - Grande }\end{array}$ \\
\hline
\end{tabular}


(FIG A) - MAPA MÍNIMO ORIGINAL, SEGUNDO SLUZKI (1997)

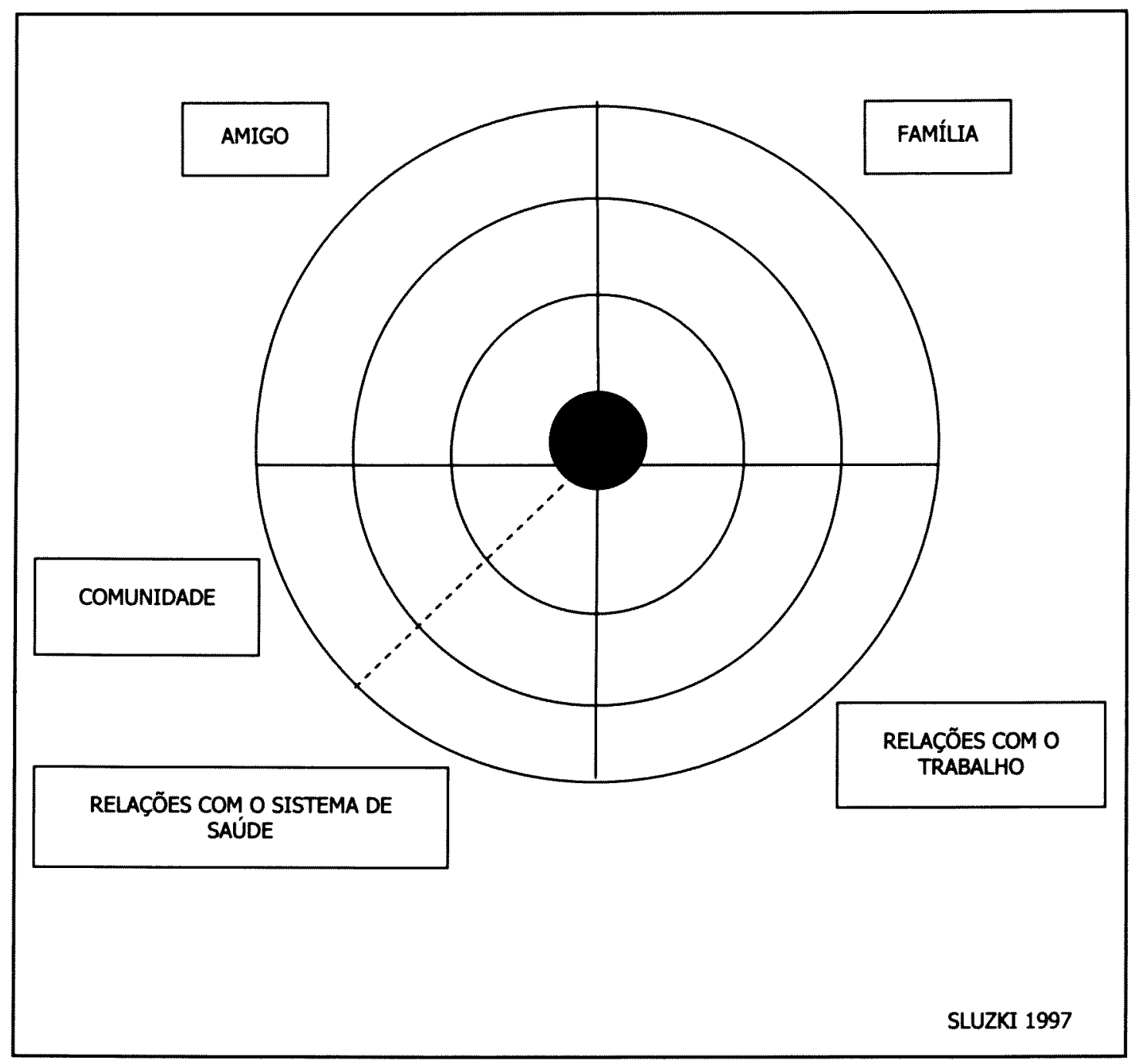


(FIG B) - MAPA MÍNIMO ADAPTADO E MODIFICADO POR DOMINGUES (2000)

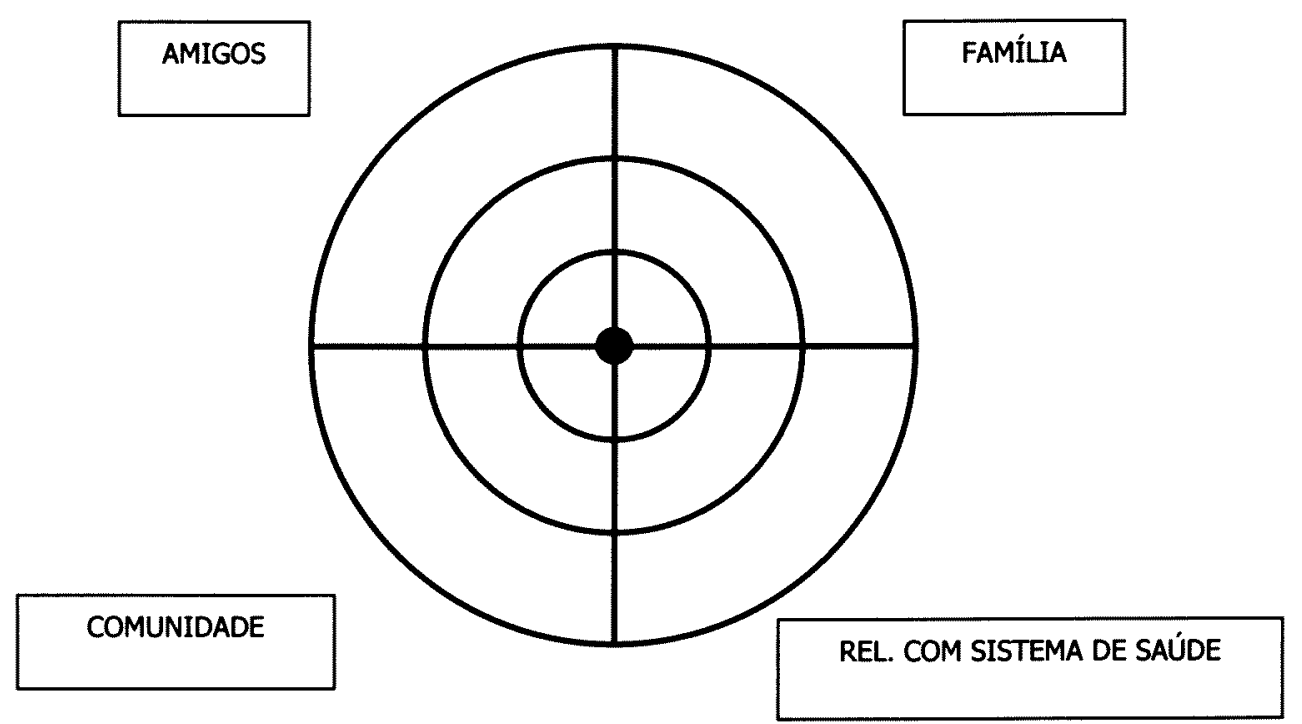

DOMINGUES (2000)

\subsection{A validação de instrumento}

A validade, acuidade ou exatidão, segundo MC DOWELL e NEWELL (1996), expressa quão verdadeiro é um instrumento ou uma escala na aferição de um dado fenômeno. Passamos a descrever, a seguir, conceitos e formas de verificar a validade de um instrumento.

\subsubsection{Validade}

Segundo GIL, a validade pode ser definida como a capacidade de um instrumento em medir realmente aquilo a que se propõe. Ela nos informa se os resultados expressam a "verdade" ou o quanto se afastam dela. O processo de validação requer vários passos, abordando domínios que devem ser verificados para considerarmos um instrumento validado (GIL 1995). 
Em pesquisas com dados subjetivos, é muito comum aferir-se a validade por meio de questionários, durante uma entrevista. As perguntas, nesse caso, são os "constructos", que medem fenômenos específicos. As respostas, convertidas em notas ou pesos, são agrupadas de modo a formar uma escala onde se registram os resultados. Tal procedimento não é tão seguro para a confirmação da validade quanto um teste clínico, por exemplo. É, contudo, segundo FLETCHER, FLETCHER e WAGNER, recomendado por ser mais adequado realizá-lo do que simplesmente supor que uma questão mede exatamente o que pretende medir. De tal forma, não seria apropriada a utilização dos termos "válida" ou "inválida" ao nos referirmos a uma escala. Ela pode ser mais ou menos válida a partir dos resultados das estratégias utilizadas (FLETCHER, FLETCHER e WAGNER 1989).

\subsubsection{Tipos de validade}

$\sqrt{ }$ Validade de critério ou em relação a um padrão. Refere-se à comparação dos resultados de um dado teste, com um já validado chamado de "padrão-ouro". Só é recomendado se os testes validados comprovadamente servirem de critério para comparação com o que se pretende validar. Tal tipo de validação é muito utilizado na área da saúde e da epidemiologia (PEREIRA 1995).

$\sqrt{ }$ Validade discriminante. É a extensão na qual os escores obtidos pela aplicação do instrumento distinguem individuos ou grupos, onde as diferenças devem ser encontradas (p. ex: pessoas sadias e doentes). Alguns erros possíveis nesse tipo de validação podem ser:

- falso positivo - quando o fenômeno é detectado em pessoas que não o possuem;

- falso negativo - o teste mostra-se incapaz para detectar o fenômeno a ser avaliado.

Temos ainda, com relação à validade discriminante, dois conceitos associados: 
- sensibilidade - capacidade de identificar o fenômeno estudado em indivíduos que o apresentam;

- especificidade - capacidade do instrumento em determinar os que não apresentam o fenômeno (Mc Dowell e Newell 1996, citados por DUARTE 2001).

$\sqrt{ }$ Validade de constructo. Este tipo de validade não pode ser definitivamente comprovada. É um contínuo processo de compreensão do conceito apresentado por meio de diferentes testes. Verifica se a característica a ser medida, correlaciona-se com uma outra, ou com o conhecimento disponível. É muito empregada em psicologia e na área da educação (GIL 1995; PEREIRA 1995).

$\sqrt{ }$ Validade de conteúdo, opinião de um júri ou validade consensual. Por esta análise, verificamos se os itens, domínios ou constructos de um instrumento representam adequadamente o que se pretende mensurar. " $\mathrm{Na}$ avaliação de testes diagnósticos", diz PEREIRA, "a validade de conteúdo pode ser utilizada para julgar a sua utilidade. $O$ teste será válido se é adequado para medir as facetas que devem ser medidas" (PEREIRA 1995, p. 368). Esse tipo de validação é utilizado para aferir alguns indicadores de saúde, como, por exemplo, os de cunho social (PEREIRA 1995 , p. 368). Ressalta o autor que, do ponto de vista clínico, tal abordagem pode ser considerada incipiente, pois é possível ocorrer concordância também no erro. Por outro lado, GIL (1995) relata que, essa forma de verificação de acurácia é utilizada e aceita nas ciências sociais e na psicologia, sendo primordial o estabelecimento de critérios rigorosos para a seleção dos especialistas, a fim de se evitar tal problema. Uma forma de verificar a validade de conteúdo é submeter o instrumento à avaliação de juízes, que se posicionarão quanto à pertinência dos itens, julgando se eles representam o conteúdo do domínio em questão (FLETCHER, FLETCHER e WAGNER 1989; GIL 1995). 


\subsection{Técnica Delfos: ferramenta para validação consensual de instrumentos}

A técnica Delfos, do latim Delphi, tem sua denominação oriunda da mitologia grega, relacionando-se ao nome do templo de Apolo, personagem que tinha o poder de transferir desejos dos deuses e visões do futuro aos mortais. É, dessa maneira, uma técnica preditiva.

Como técnica, foi criada por Olav HELMER e DALKEY, o primeiro matemático e o segundo filósofo, ambos ingleses, baseando-se na intuição de grupos para ampliar projeções individuais. Posteriormente foi utilizada para prever acontecimentos de uma vasta gama de setores, implementando alternativas de ação pela obtenção de consenso (SPÍNOLA 1984; FARO 1997).

Atualmente possui uso generalizado no campo das Ciências Sociais, sendo largamente utilizada para se alcançar decisões grupais.

O conceito de Delfos pode ainda ser entendido como um método de coleta de dados quantitativos, realizado por meio de uma sucessão de questionários. Sua utilização é indicada quando há falta de acordo ou conhecimento incipiente de uma situação (SPÍNOLA 1984; WILLIAMS e WEBB 1994; FARO 1997).

Quanto à terminologia, "método" ou "técnica", diz Spínola:

as regras seguidas nas investigações científicas habitualmente denominam-se método, sendo os instrumentos utilizados para a sua operacionalização a técnica empregada. Desta forma, método é o seguimento de um caminho, conforme um plano prefixado. Já a técnica diz respeito aos diversos procedimentos ou a utilização de recursos, dentro das diversas etapas do método. Seria, por conseguinte, a instrumentação da ação dentro de um contexto geral (SPÍNOLA 1984, p. 68).

Por comungarmos dessa opinião, utilizamos nesta pesquisa o conceito de técnica e a forma aportuguesada do nome originário em latim, ou seja, "técnica Delfos". Essa técnica consiste na cooperação de um grupo de especialistas que respondem a uma série de questionários, sendo o correio um dos meios utilizados 
para o seu envio (SPÍNOLA, 1984, p. 50). Para tanto, no primeiro instrumento remete-se também aos juízes selecionados uma carta explicitando a técnica, o instrumento que será julgado e o objetivo do estudo (SPÍNOLA 1984; POLIT 1987; FARO 1997).

Para a análise dos resultados, um método bastante utilizado é a escala do tipo Likert ${ }^{3}$. O consenso é obtido pelo valor médio dos itens do instrumento, sendo apontado pela literatura o indice de $70 \%$ de opiniões convergentes como o aceitável para se ter um instrumento validado consensualmente por esta técnica (ÁVILA e SANTOS 1988; WILLIAMS e WEBB 1994; FARO 1995; ALMEIDA 2003).

Além da obtenção do consenso, como acima descrito, é importante que o pesquisador esteja atento aos fatores que podem influenciar sua validade tanto interna quanto externa.

Quanto à validade interna, faz-se necessário o rigor na seleção dos especialistas, para que se evite um viés pertinente a esse tipo de validação. Quanto a esse aspecto, SPÍNOLA afirma que "a técnica Delfos para a obtenção de consenso tem se mostrado bastante adequada e aceita como estratégia de validação consensual de instrumentos, em função do grau dos especialistas selecionados, sendo dessa maneira um recurso útil para saúde pública" (SPÍNOLA 2002, p. 2).

Recomenda-se ainda, quanto à validade interna, a observância de fatores não controlados que podem interferir nos resultados, como, por exemplo, as reaplicações poderem predispor os informantes a se desinteressarem pela pesquisa, fazendo com que se conte apenas com os mais interessados. POLIT (1987) e SPÍNOLA (2002) recomendam entre duas a quatro aplicações para que o processo não se torne desgastante, predispondo a esse tipo de viés.

No que diz respeito à validade externa, deve-se ter o cuidado de observar se o dado encontrado pode ser generalizado, ou se é válido apenas para os participantes do estudo (SPÍNOLA 1984; POLIT 1987).

\footnotetext{
${ }^{3}$ A escala de Likert consiste no registro das respostas às perguntas formuladas, em uma escala analógica, com graduações que variam da total concordância à total discordância (GIL 1995).
} 


\subsubsection{Aplicações da Técnica Delfos}

No campo das ciências sociais, da saúde e também na área da educação, a técnica Delfos tem sido utilizada para que se busque a convergência de opiniões de um grupo de especialistas em um dado tema, sendo um recurso utilizado para se verificar a validade consensual de instrumentos.

Para avaliar questões relativas a aspectos educacionais, SPIVEY (1971), MATTHEWS e col. (1975), LAWRENCE e col. (1983) e BEECH (1991) empregaram a técnica Delfos prevendo a validação de conteúdos e planos curriculares para área da enfermagem.

No âmbito das ciências sociais, ÁVILA e SANTOS (1988) a utilizaram para avaliar as políticas para o setor público. Segundo os autores, a técnica Delfos, por combinar métodos quantitativos e qualitativos, pode ser um recurso bastante útil nesse tipo de pesquisa.

Quanto ao emprego da técnica Delfos na área da saúde, FARO (1995) a utilizou para validar as intervenções de enfermagem destinadas aos pacientes com lesão medular em reabilitação. Essa pesquisa ocorreu em uma instituição governamental na cidade de São Paulo, que desenvolvia programas de reabilitação para portadores de deficiência física sensorial incapacitante. Foram aplicados três questionários a um grupo de juízes, todos da área da enfermagem, tendo sido obtida opinião claramente convergente na segunda fase de coleta de informações (FARO 1995).

PIOLA,VIANNA e VIVAS-CONSUELO (2002) realizaram uma pesquisa intitulada "Estudo Delphi: atores sociais e tendências do sistema de saúde brasileiro", com o objetivo de identificar as principais tendências de saúde no Brasil para a primeira década do século XXI, segundo o entendimento de formadores de opinião, selecionados entre diversos segmentos envolvidos com o tema.

ALMEIDA (2003) validou, por meio da técnica Delfos, um instrumento denominado CICAs - Classificação de Idosos quanto à Capacidade para o Autocuidado, com o objetivo de avaliar a capacidade do idoso para realizar tais atividades. $\mathrm{O}$ estudo contou com um grupo de juízes da área da terapia ocupacional que, ao final da terceira aplicação, expressou uma opinião convergente quanto ao 
instrumento. Além de realizar a validação consensual, ALMEIDA efetuou também o estudo da confiabilidade do CICAs (ALMEIDA 2003).

\subsubsection{Técnica Delfos: vantagens e desvantagens}

Segundo SPÍNOLA (2002, p. 10), como toda técnica, esta também possui vantagens e desvantagens.

Como vantagens podemos destacar:

$\sqrt{ }$ o fato de favorecer a expressão de opinião com maior franqueza, uma vez que essa técnica favorece a interação grupal, mantendo o anonimato de seus participantes, tornando facultativa a presença do entrevistador;

$\sqrt{ }$ a escolha do momento mais adequado ao respondente para realizar o preenchimento do questionário, em função da sua disponibilidade de tempo, propiciando uma opinião mais elaborada, com maior reflexão sobre o tema;

$\sqrt{ }$ o interesse dos juízes, uma vez que o nível de recusa em participar desse tipo de pesquisa, não é elevado.

Já quanto às desvantagens, estas podem ser assim descritas:

$\sqrt{ }$ a possibilidade de extravio ou recebimento incompleto do material, pela utilização do correio postal para o envio dos questionários;

$\sqrt{ }$ o desinteresse dos juízes na continuidade da pesquisa, caso ocorram muitas reaplicações.

Para se evitar essas desvantagens, a motivação do informante é muito importante. Procura-se obtê-la com o envio de carta convite, explicando o motivo e a importância da participação do escolhido na pesquisa, e também remetendo envelope já selado para as respostas, facilitando o envio por parte do juiz (POLIT 1987; FARO 1997; SPÍNOLA 1984, 2002). 


\section{OBJETIVO}

Buscar o consenso, por meio da consulta a especialistas, sobre a clareza, a pertinência das perguntas e a adequação do instrumento gráfico para identificar a rede de suporte social do idoso - Mapa Mínimo de Relações do Idoso (MMRI). 


\section{MÉTODO}

\subsection{Justificativa do método utilizado}

A aplicação de instrumentos validados no campo do suporte social é cada vez mais usual e necessária (DUARTE 2002; MATSUKURA, MARTURANO e OISHI 2002; GRIEP, CHOR, FAERSTEIN e LOPES 2003). Não há, contudo, nenhum instrumento gráfico validado para a identificação de tal suporte ao idoso.

Neste sentido, a opção desta pesquisa em utilizar a técnica Delfos para verificar o consenso grupal dos especialistas sobre um instrumento gráfico, o MMRI, se deu por ela possibilitar, segundo SPÍNOLA $(1984,2002)$ e POLIT (1987), a ocorrência dos seguintes fatores:

- a troca de opiniões e experiências entre os profissionais, sendo indutora de relacionamentos sobre um dado tema;

- a valorização dos profissionais especialistas na área da pesquisa;

- o conhecimento numa área onde a sistematização dos dados é ainda incipiente.

Reiteramos que instrumentos validados para avaliação de suporte social são de suma importância para termos dados mais precisos acerca da rede de relações do idoso. Cabe, portanto, tanto ao profissional da área do Serviço Social quanto aos demais integrantes da equipe de saúde devidamente capacitados, sua aplicação para que se possa formular um diagnóstico sociofamiliar mais preciso, possibilitando a formulação de condutas adequadas para cada caso (ANDER-EGG 1996).

\subsection{Operacionalização do processo de validação consensual da pesquisa}

\subsubsection{Critérios para seleção dos juízes}

Segundo SPÍNOLA (2002), quando se utiliza a técnica Delfos, o tamanho do grupo de especialistas pode ficar a critério do pesquisador, que o definirá tendo por base a competência dos juizes e a possibilidade de operacionalização do estudo. Para este trabalho definimos os seguintes números: 
- $10(\mathrm{dez})$ juízes para a pesquisa;

- 1 (um) juiz para o pré-teste;

- 4 (quatro) suplentes, para o caso de ocorrerem negativas de algum dos juízes selecionados.

Cabe salientar que os juízes suplentes não foram acionados, pois não obtivemos nenhuma recusa dos especialistas escolhidos. Sendo assim, essa pesquisa foi realizada com os 11 (onze) juízes selecionados.

Como critérios para a seleção, estabelecemos os seguintes requisitos:

$\sqrt{ }$ ser especialista em Gerontologia com, no mínimo, 2 anos de experiência no trabalho com família, apoio social ou comunitário (rede de suporte social); ou

$\sqrt{ }$ possuir formação na área da teoria ou terapia familiar sistêmica, por ser a base conceitual do mapa mínimo de relações.

Foi também um critério de seleção dos juízes contarmos com profissionais de diversas áreas de atuação da gerontologia, desde que preenchessem os requisitos acima estabelecidos.

Os juízes que compuseram a pesquisa possuíam formação nas seguintes áreas: enfermagem, medicina, psicologia, serviço social e terapia ocupacional. Dos selecionados, 7 (sete) eram especialistas em Gerontologia, pela Sociedade Brasileira de Geriatria e Gerontologia e filiados à seção São Paulo - SBGG/SP, e 3 (três) especialistas em terapia familiar sistêmica, filiados à Associação Paulista de Terapia Familiar - ATP. A inclusão de especialistas em terapia familiar se deu pelo domínio e conhecimento acerca do instrumento, por ser o MMRI, um instrumento de cunho conceitual sistêmico.

O acesso aos profissionais foi efetivado pela solicitação aos especialistas, feita pela pesquisadora. O primeiro contato foi realizado de maneira informal, por telefone, quando se explicou o tipo e objetivo de estudo e a técnica a ser utilizada. Para aqueles que se disponibilizaram a participar da pesquisa emitiu-se um convite formal, por meio de uma carta. Os dez primeiros juízes que aceitaram participar do 
estudo foram classificados como titulares e os outros cinco como pré-teste e suplentes.

No quadro abaixo, descrevemos a distribuição dos profissionais por especialidade.

Número de Juizes, formação profissional e especialidade

\begin{tabular}{|l|cc|}
\hline Formação Profissional & \multicolumn{2}{|c|}{ Especialidade } \\
\hline Psicólogo & 1 \\
\hline Assistente Social & 4 (incluindo pré-teste) \\
\hline Médico & 1 \\
\hline Enfermeira & 1 \\
\hline Terapeuta Ocupacional & 1 \\
\hline
\end{tabular}

$n=11$

\subsubsection{Coleta de dados}

\subsubsection{O Pré-Teste: primeira etapa da pesquisa}

A primeira etapa da pesquisa foi realizada logo após a análise e conseqüente aprovação pelo Comitê de Ética em Pesquisa da Faculdade de Saúde Pública da Universidade de São Paulo - COEP (Anexo 2). Esta primeira etapa consistiu no encaminhamento, por meio eletrônico, a uma juíza, gerontóloga, da carta convite para participar do pré-teste (Anexo 3), do Primeiro Questionário Delfos do instrumento a ser validado - fase de pré-teste (Anexo 4) e do termo de consentimento livre e esclarecido (Anexo 5).

A juíza considerou o instrumento de coleta de dados adequado quanto à sua clareza, pertinência e forma de registro, sem sugerir alterações quanto à formulação das perguntas não sendo necessários, portanto, ajustes para a continuidade da pesquisa.

\subsubsection{Convite aos juízes}

Como já descrito no item 4.2.1, o convite aos juízes da pesquisa foi inicialmente feito por telefone. A formalização, aos que se disponibilizaram participar do estudo, foi efetivada por meio do envio do termo de consentimento livre 
e esclarecido (Anexo 5), da $1^{\text {a }}$ carta convite apresentando a pesquisa, explicitando seu objetivo e a importância da participação do especialista (Anexo 6), e do Primeiro Questionário Delfos do instrumento a ser validado (Anexo 7).

\subsubsection{Fases de aplicação da pesquisa}

Para mantermos o anonimato dos juízes e um modo mais afetivo de comunicação com os mesmos, optamos por identificá-los por nomes de pedras preciosas, em vez de utilizarmos símbolos ou números. Dessa maneira, eles foram assim denominados: Ágata, Água-Marinha, Esmeralda, Jade, Ônix, Opala, Rubi, Safira, Topázio, Turmalina.

$\mathrm{Na}$ primeira aplicação do instrumento, o material foi enviado por correio postal para um juiz, e, para os demais, por meio eletrônico, atendendo à preferência de cada especialista. Esse meio é apontado por WOUNDENBERG (1991) e LUDWIG (1997) como mais um recurso interativo disponível que pode ser utilizado para facilitar o processo de obtenção de consenso.

O material expedido pelo correio foi postado com envelope já selado para facilitar a remessa da resposta, sendo o prazo para a devolução, em ambos os casos correio postal ou eletrônico -, de 15 dias. Tal período foi definido tendo como base as pesquisas de FARO (1997) e ALMEIDA (2003), que também utilizaram a técnica Delfos. Em ambos os casos, os questionários eram mais extensos que o MMRI, tendo as pesquisadoras estipulado um prazo de 10 e 15 dias respectivamente para o envio do material. Sendo assim, julgamos ser suficiente o prazo de 15 dias para a análise dos juízes a cada aplicação do instrumento (FARO 1997; ALMEIDA 2003).

A partir do recebimento dos instrumentos preenchidos pelos juízes, tabulamos os dados, elaborando um novo questionário com as questões consensuais.

Uma nova carta convite foi então enviada aos mesmos juízes (Anexo 8), juntamente com novo questionário produzido (Anexo 9).

Realizamos uma terceira aplicação, enviando aos juizes uma nova carta convite (Anexo 10) e apenas para a pergunta de número cinco do MMRI, que, afinal, obteve consenso (Anexo 11). 
Em todas as etapas da aplicação do MMRI remetemos para cada juiz as tabelas com o posicionamento individual frente ao instrumento analisado, $o$ posicionamento do grupo, todas as sugestões e observações formuladas, a nota de cada especialista para cada questão, a média e mediana obtidas, permitindo, como recomenda a técnica, que cada um conhecesse e comparasse sua posição frente aos demais, promovendo, assim, a interação grupal (SPÍNOLA 1984; LUDWIG 1997 e WOUNDENBERG 1991).

Para a elaboração desse material, as notas fornecidas em cada pergunta, segundo a escala de Lickert, foram transformadas em conceitos assim definidos:

- 1 discordo totalmente

- 2 discordo parcialmente

- 3 indeciso

- 4 concordo parcialmente

- 5 concordo totalmente

Esses dados serão apresentados no capítulo 5.

O consolidado de sugestões e observações fornecido a cada aplicação deu origem a uma categorização assim nomeada: enunciado, treinamento do pesquisador e referencial. A categoria enunciado expressa as sugestões emanadas pelos especialistas para que se aprimore a clareza das perguntas. A categoria treinamento do pesquisador expressa apenas o treinamento. Agrupamos as sugestões relativas à necessidade dessa prática para que os profissionais pudessem aplicar o instrumento. Por fim, construímos uma categoria que denominamos de referencial, para abarcar as sugestões recebidas quanto à necessidade de aprimorar definições e conceitos que permeiam o instrumento.

Quanto à categoria de sugestões, acatamos aquelas que se referiram ao enunciado, realizando as alterações propostas para aprimorar a clareza das perguntas, nas três etapas da pesquisa. As relativas à categoria referencial também foram aceitas e incorporadas nos capítulos iniciais deste trabalho. Quanto à de treinamento, incluímos no corpo do instrumento um tópico de esclarecimento ao entrevistador, para subsidiá-lo quanto à aplicação do MMRI e o recomendamos, como requisito fundamental para a sua adequada aplicação. 
Dessa forma, o instrumento obteve consenso entre os juízes após sua terceira aplicação, com um percentual de opiniões convergentes superior ao proposto para essa pesquisa, que foi de $70 \%$ de aprovação dos especialistas. A obtenção do consenso após a terceira aplicação referenda os dados da literatura, que consideram entre duas e quatro o número adequado de aplicações, demonstrando a consistência do instrumento (SPÍNOLA, 1984, 2002; POLIT 1987; FARO 1997).

Esquematizamos o processo metodológico de coleta de dados das três fases da Técnica Delfos, no quadro que se segue, no qual comparamos as alterações que ocorreram a cada fase.

\section{Coleta de Dados}

\begin{tabular}{|c|c|c|}
\hline $1^{\text {a }}$ FASE & $2^{a}$ FASE & $3^{a}$ FASE \\
\hline 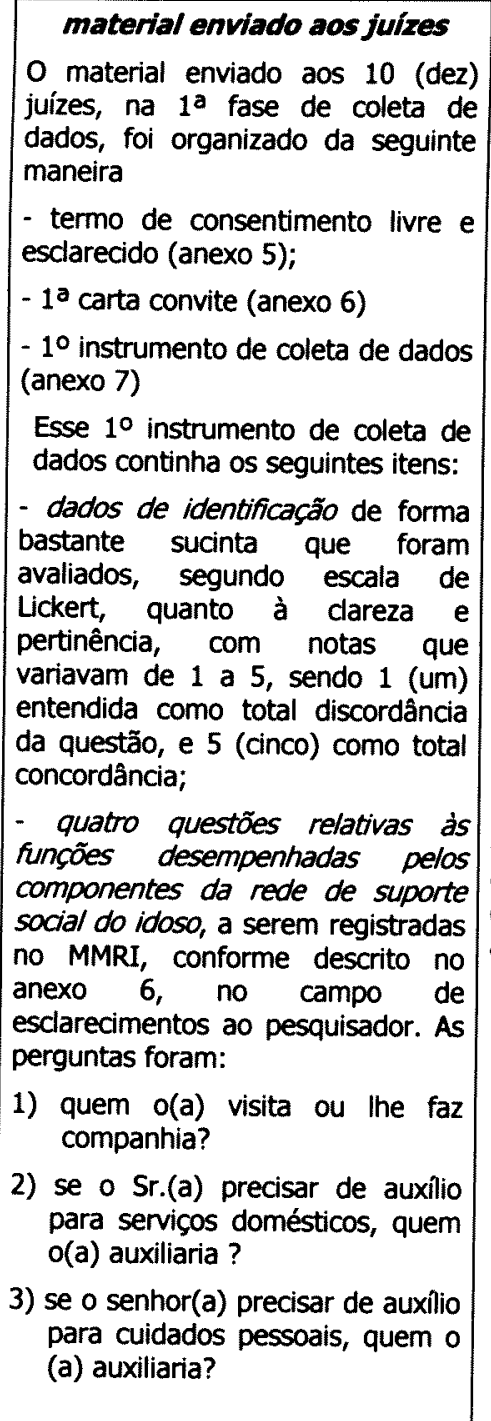 & 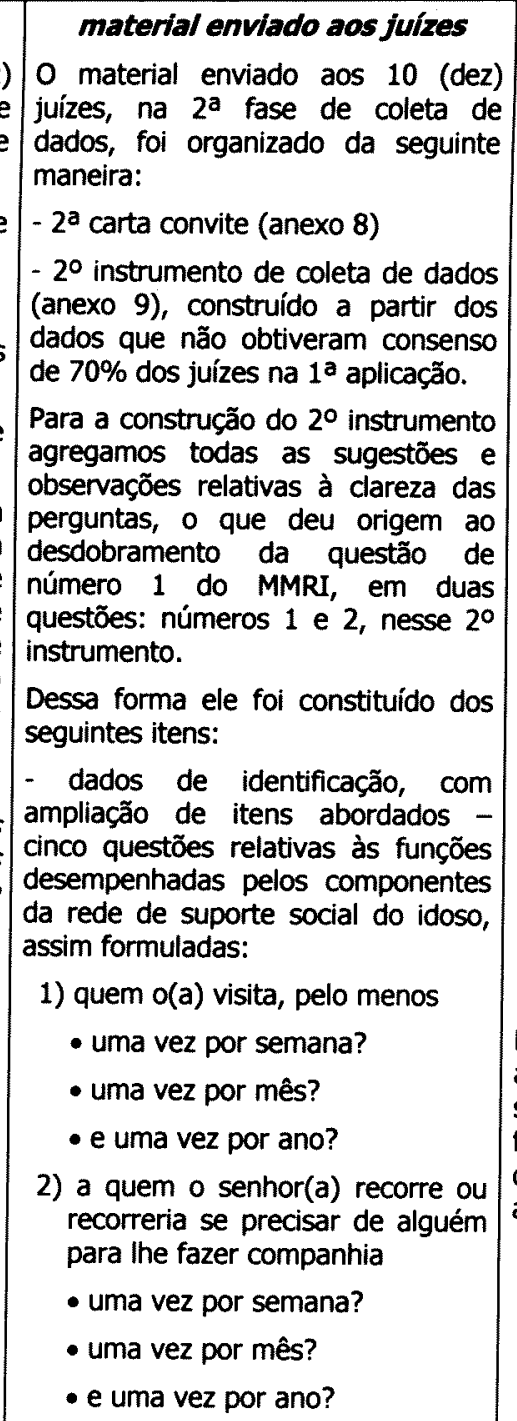 & 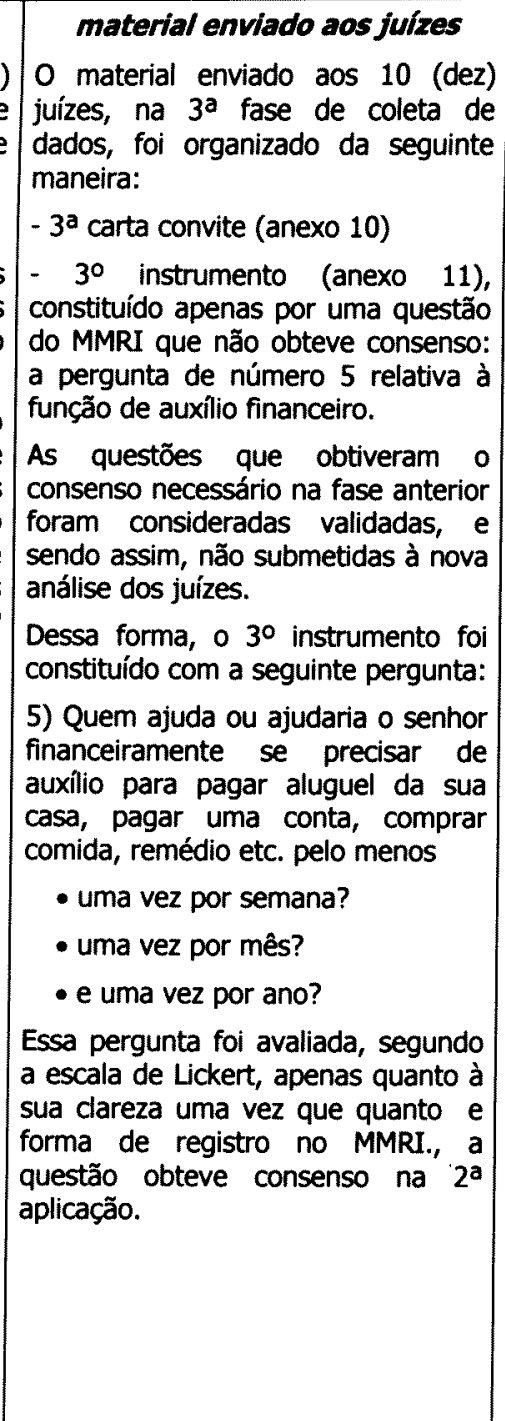 \\
\hline
\end{tabular}




\begin{tabular}{|c|c|c|}
\hline $\begin{array}{l}\text { 4) se o senhor(a) precisar de auxílio } \\
\text { financeiro, quem o auxiliaria? } \\
\text { Cada uma dessas perguntas foi } \\
\text { também avaliada, segundo a escala } \\
\text { de Lickert, quanto à clareza, } \\
\text { pertinência e forma de registro no } \\
\text { MMRI. } \\
\text { Formulamos ainda uma última uma } \\
\text { questão relativa à adequação da } \\
\text { forma gráfica de registro de } \\
\text { respostas: Mapa Mínimo de } \\
\text { Relações. }\end{array}$ & 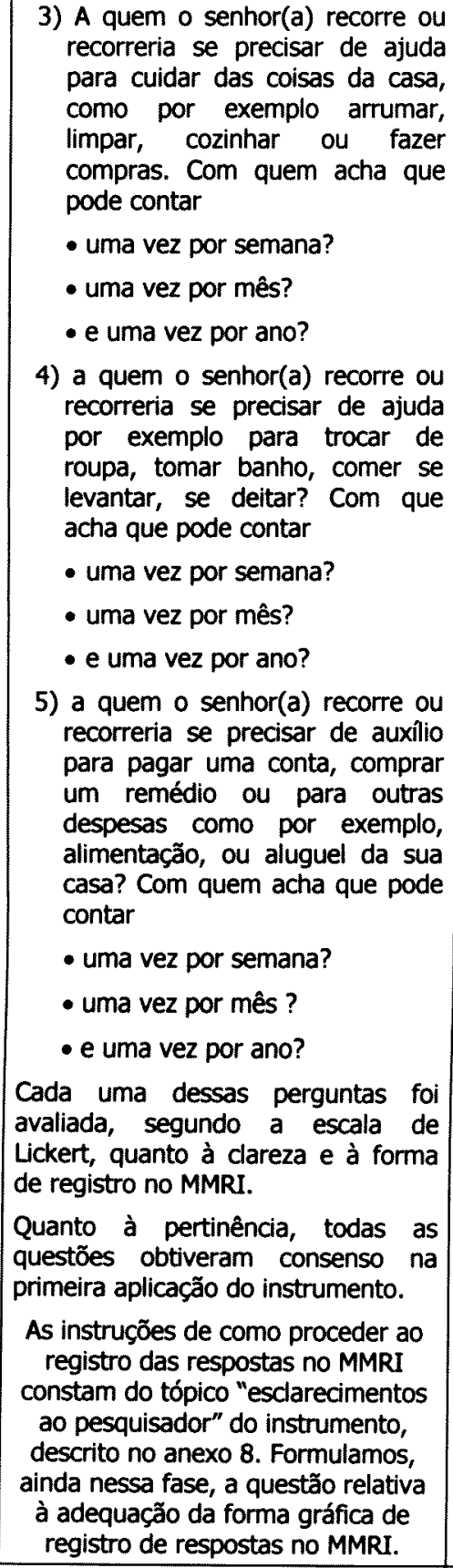 & \\
\hline $\begin{array}{l}\text { Forma de envio do material de } \\
\text { pesquisa }\end{array}$ & $\begin{array}{l}\text { Forma de envio do material de } \\
\text { pesquisa }\end{array}$ & $\begin{array}{c}\text { Forma de envio do material de } \\
\text { pesquisa }\end{array}$ \\
\hline $\begin{array}{l}\text { o material foi enviado pela } \\
\text { pesquisadora a nove juízes por } \\
\text { e-mail, sendo a resposta recebida } \\
\text { também por meio eletrônico. } \\
\text { Apenas para um juiz o envio e } \\
\text { recebimento do material preenchido } \\
\text { foi efetuado por correio postal. }\end{array}$ & $\begin{array}{l}\text { O material da } 2^{a} \text { fase de coleta de } \\
\text { dados foi enviado pela pesquisadora } \\
\text { aos dez juízes por e-mail, sendo as } \\
\text { respostas dos juizes também } \\
\text { enviadas por meio eletrónico. }\end{array}$ & $\begin{array}{l}\text { O material da } 3^{\text {a }} \text { fase de coleta de } \\
\text { dados foi enviado pela pesquisadora } \\
\text { aos dez juízes por e-mail, sendo as } \\
\text { respostas dos juízes também } \\
\text { enviadas por meio eletrônico. }\end{array}$ \\
\hline Prazo para envio das resposta & Prazo para envio das respostas & Prazo para envio das respostas \\
\hline $\begin{array}{l}\text { O material preenchido pelos juízes } \\
\text { foi remetido à pesquisadora no } \\
\text { prazo solicitado } 15 \text { dias. }\end{array}$ & $\begin{array}{l}\text { O material preenchido pelos juízes } \\
\text { foi enviado à pesquisadora, dentro } \\
\text { do prazo solicitado } 15 \text { dias. }\end{array}$ & $\begin{array}{l}\text { O material preenchido por seis juízes } \\
\text { foi remetido à pesquisadora, dentro } \\
\text { do prazo solicitado,15 dias, e pelos } \\
\text { demais, fora da data prevista. }\end{array}$ \\
\hline
\end{tabular}




\begin{tabular}{|c|c|c|}
\hline Tabulação dos dados & Tabulação dos dados & Tabulação dos dados \\
\hline $\begin{array}{l}\text { A tabulação de dados nas três } \\
\text { fases da pesquisa ocorreu da } \\
\text { seguinte maneira; }\end{array}$ & $\begin{array}{l}\text { A tabulação de dados nas três fases } \\
\text { da pesquisa ocorreu da seguinte } \\
\text { maneira; }\end{array}$ & $\begin{array}{l}\text { A tabulação de dados nas três fases } \\
\text { da pesquisa ocorreu da seguinte } \\
\text { maneira; }\end{array}$ \\
\hline $\begin{array}{l}\text { partir das notas para cada } \\
\text { pergunta que variava de } 1 \text { (total } \\
\text { discordância) a } 5 \text { (total concor- } \\
\text { dância) elaboramos de planilhas } \\
\text { com as notas atribuídas a cada } \\
\text { pergunta, por juiz e as, médias e } \\
\text { medianas por questão. Cada } \\
\text { questão teve ainda um campo para } \\
\text { sugestões e observaçães que foi } \\
\text { analisado com a construção de } \\
\text { categorias. }\end{array}$ & $\begin{array}{l}\text { partir das notas para cada } \\
\text { pergunta que variava de } 1 \text { (total } \\
\text { discordância) a } 5 \text { (total concor- } \\
\text { dấncia) elaboramos de planilhas } \\
\text { com as notas atribuídas a cada } \\
\text { pergunta, por juiz e as, médias e } \\
\text { medianas por questão. Cada } \\
\text { questão teve ainda um campo para } \\
\text { sugestões e observações que foi } \\
\text { analisado com a construção de } \\
\text { categorias }\end{array}$ & $\begin{array}{l}\text { partir das notas para cada } \\
\text { pergunta que variava de } 1 \text { (total } \\
\text { discordância) a } 5 \text { (total concor- } \\
\text { dância) elaboramos de planilhas } \\
\text { com as notas atribuídas a cada } \\
\text { pergunta, por juiz e as, médias e } \\
\text { medianas por questão. cada } \\
\text { questão teve ainda um campo para } \\
\text { sugestões e observações que foi } \\
\text { analisado com a construção de } \\
\text { categorias }\end{array}$ \\
\hline $\begin{array}{l}\text { Devolutiva aos juízes e } \\
\text { formulaçáo do } 2^{\circ} \text { instrumento }\end{array}$ & $\begin{array}{l}\text { Devolutiva aos juízes e } \\
\text { formulaçáo do } 3^{\circ} \text { instrumento }\end{array}$ & $\begin{array}{l}\text { Devolutiva aos juízese } \\
\text { finalizaçáo da pesquisa: } \\
\text { formulaça do instrumento } \\
\text { validado consensualmente }\end{array}$ \\
\hline $\begin{array}{l}\text { A devolutiva foi realizada } \\
\text { enviando, por e-mail, para cada } \\
\text { juiz, uma planilha com a nota e } \\
\text { comentários sobre cada pergunta, } \\
\text { e o posicionamento dos demais } \\
\text { juizes, além da média e mediana } \\
\text { de cada questão. Isso permitiu que } \\
\text { cada um verificasse a posição de } \\
\text { sua resposta em relação à do } \\
\text { grupo, e o pensamento dos demais } \\
\text { especialistas sobre o assunto. }\end{array}$ & $\begin{array}{l}\text { A devolutiva foi realizada enviando, } \\
\text { por e-mail, para cada juiz, a } \\
\text { planilha com a sua nota e } \\
\text { comentários sobre cada questão e o } \\
\text { posicionamento dos demais juízes, } \\
\text { além da média e mediana de cada } \\
\text { questão. Com esse material envia- } \\
\text { mos também o terceiro instrumento } \\
\text { formulado apenas com uma questão } \\
\text { do Mapa Mínimo de Relações, que } \\
\text { não obteve consenso: a pergunta de }\end{array}$ & $\begin{array}{l}\text { Após a } 3^{a} \text { aplicação, a questão sobre } \\
\text { auxílio financeiro obteve } 90 \% \text { de } \\
\text { opiniőes convergentes sendo também } \\
\text { considerada validada consensual- } \\
\text { mente. A partir desse resultado, } \\
\text { construímos o instrumento final no } \\
\text { qual agregamos todas as sugestões } \\
\text { e observações relativas à clareza das } \\
\text { perguntas, conforme descrito no } \\
\text { item 4.3. }\end{array}$ \\
\hline $\begin{array}{l}\text { Além dessa planilha, enviamos } \\
\text { também o segundo instrumento de } \\
\text { coleta de dados construído para as } \\
\text { questões que não obtiveram } \\
\text { consenso estipulado para esse } \\
\text { trabalho, } 70 \% \text { de opiniōes } \\
\text { convergentes }\end{array}$ & $\begin{array}{l}\text { número } 5 \text { do MMRI relativa à } \\
\text { função de auxílio financeiro. }\end{array}$ & \\
\hline $\begin{array}{l}\text { Para o envio das informações em } \\
\text { todas as fases da pesquisa, a } \\
\text { manutenção do anonimato dos } \\
\text { juízes se deu pela adoção de } \\
\text { nomes de pedras preciosas para } \\
\text { designar cada especialista, como já } \\
\text { descrito no início deste capítulo. }\end{array}$ & & \\
\hline
\end{tabular}

Contamos ainda com a participação do autor do instrumento original, Prof. Carlos Sluzki, a quem enviamos por e-mail o MMRI para a sua apreciação e comentários. No parecer do Prof. Sluzki, o instrumento mostra-se bem estruturado sendo uma útil ferramenta para a aplicação em Saúde Pública (Anexo 12). 


\subsection{Instrumento final}

O MMRI obteve um consenso parcial após a segunda aplicação, sendo necessária uma terceira análise apenas para uma pergunta, que se referia a auxílio financeiro. Após essa etapa, o instrumento obteve, para todas as perguntas, médias superiores às definidas pelo estudo, que foi de 0,70 , sendo para esses juízes, validado consensualmente.

Apresentamos a seguir o instrumento final com os ajustes e sugestões preconizados pelos juízes ao longo de todo o processo.

\section{ESCLARECIMENTOS AO ENTREVISTADOR}

A freqüência dos contatos, para fins do preenchimento do MMRI, é entendida segundo a percepcáa do idoso frente às pessoas do seu círculo de relacionamento. $\dot{E}$ importante ressaltar que esse instrumento não verifica a qualidade dos contatos, e sim sua efetivação.

Antes do inicio da entrevista, mostra-se ao pesquisado o instrumento, esclarecendo a sua localização no mapa, e como o mesmo será preenchido.

0 entrevistador deve estar atento para o caso de o idoso se referir à pessoa pelo nome ou apelido. Neste caso, deve-se perguntar: $O$ que o senhor(a) é dele(a)? Após o esclarecimento do(a) idoso(a), correlaciona-se o nome ou apelido a cada um dos quadrantes descritos no instrumento e então preenche o MMRI.

Para que o pesquisador não se perca no momento de registrar as respostas, recomenda-se que o faça no sentido horário iniciando pelo quadrante de relações com a familia.

Foi previsto no instrumento, na página final, um espaço para observaçöes do entrevistador, onde poderão ser registradas ou justificadas as respostas do(a) idoso(a) que forem necessárias, além de ser também possivel, neste campo, descrever as relações significativas mencionadas no quadrante de relaçóes com sistema de saúde/socais e amigos.

\section{INSTRUÇÕES}

Formulam-se ao(a) pesquisado(a), identificado(a) pelo círculo escuro no centro do MMRI, as seguintes perguntas:

1) Quais as pessaas que o(a) visitam pelo menos:

- uma vez por semana (freqüentemente)?

- uma vez por mês (pouco freqüentemente)?

- e uma vez por ano (raramente)?

2) Com quem o(a) senhor(a) pode contar se desejar ou precisar de alguém para the fazer companhia:

- uma vez por semana (freqüentemente)?

- uma vez por mês (pouco freqüentemente)?

- e uma vez por ano (raramente)? 
3) A quem o(a) senhor(a) recorre ou recorreria se precisar de ajuda para cuidar das coisas da casa, como, por exemplo, arrumar, limpar, cozinhar ou fazer compras:

- uma vez por semana (freqüentemente)?

- uma vez por mês (pouco freqüentemente)?

- e uma vez por ano (raramente)?

4) A quem o(a) senhor (a) recorre ou recorreria se precisar de ajuda para cuidados pessaais, como, por exemplo, trocar de roupa, tomar banho, comer, se levantar ou se deitar:

- uma vez por semana (freqüentemente)?

- uma vez por mês (pouco freqüentemente)?

- e uma vez por ano (raramente)?

5) Quem ajuda ou ajudaria o(a) senhor(a) financeiramente se precisar de auxilio para pagar o aluguel da sua casa, pagar uma conta, comprar remédio, comida etc.:

- uma vez por semana (freqüentemente)?

- uma vez por mês (pouco freqüentemente)?

- e uma vez por ano (raramente)?

As respostas serão registradas no MMRI pelo número da pergunta formulada e a abreviaçóes correspondentes aos quadrantes relativos à "familia" $e$ à "comunidade". Nos quadrantes relativos a amigos e relações com sistema de saúde/social registra-se a resposta também pelo número da pergunta, e um ponto (•) que significa uma pessoa mencionada. $O$ registro dessas respostas nos círculos, que identificam a freqüência de contatos com o idoso, será realizado da seguinte forma:

Resposta do idoso: pelo menos uma vez por semana (freqüentemente)

Registro no MMRI: maior freqüência de contatos com o idoso, sendo a resposta registrada no $1^{\circ}$ círculo de freqüência de contatos

Resposta do idoso: pelo menos uma vez por mês (pouco freqüentemente)

Registro no MMRI: pouca freqüencia de contatos com o idoso, sendo a resposta registrada no $2^{\circ}$ círculo de freqüência de contatos

Resposta do idoso: pelo menos uma vez por ano (raramente)

Registro no MMRI: rara freqüencia de contato com o idoso, sendo a resposta registrada no 30 ćrculo de freqüência de contatos 


\section{ESCLARECIMENTOS AO ENTREVISTADOR}

\section{PERGUNTASA SEREM REGISTRADAS NO MMRI}

(Pergunta que identifica a função de número 1) Quais as pessoas que o(a) visitam pelo menos uma vez por semana?

Resposta: minha filha e meu irmão.

Registro no MMRI: o registro será feito no $1^{\circ}$ circulo de freqüência de contatos com o número 1 (referente ao número da pergunta que identifica a função visita), ao lado das abreviações fa $e$ io (abreviação de filha e irmão) e deverão ser registradas no quadrante de relaçóes com a familia.

Quais as pessoas que o(a) visitam pelo menos uma vez por mês?

Resposta: minha vizinha e uma amiga da minha igreja.

Registro no MMRI: o registro será feito no $2^{\circ}$ círculo de freqüência de contatos com o número 1 (referente ao número da pergunta que identifica a função visita) $e$ a abreviação vi (vizinho) e gr (grupo religioso), no quadrante de relações com a comunidade.

Quais as pessoas que o(a) visitam pelo menos uma vez por ano?

Resposta: minha amiga, que mora em outra cidade e vem passar o natal aqui com os filhos e a irmã.

Registro no MMRI: o registro será feito no 30 círculo de freqüência de contatos com o número 1 (referente ao número da pergunta que identifica a função visita) e um ponto (•) símbolo de uma relação significativa no quadrante de amigos.

(Pergunta que identifica a função de número 2) Quem the faz companhia pelo menos uma vez por semana?

Resposta: O Jã̃o, e uma moça que trabalha aqui em casa.

Pergunta do pesquisador: Eo João é o que seu?

Resposta da idosa: Ele é meu esposo/marido

Registro no MMRI: O registro será feito no $1^{\circ}$ círculo de freqüência de contatos com o número 2 (referente ao número da pergunta que identifica a função companhia) $e$ a abreviação eo (esposo) no quadrante de familia, e ps (prestador de serviço), no quadrante de relações com a comunidade.

Quem the faz companhia pelo menos uma vez por mês?

Resposta: Minha neta que mora em outra cidade e vem passar uns dias comigo. Sabe eu sou irmã da mãe dela e a criej. Ela é como uma filha.

Registro no MMRI: O registro será feito no $2^{\circ}$ círculo de freqüência de contatos com o número 2 (referente ao número da pergunta que identifica a função companhia) e a abreviação na (neta) no quadrante de familia.

Quem Ihe faz companhia pelo menos uma vez por ano?

Resposta: Não tem mais ninguém, não senhora.

Registro no MMRI: Fica em branco, pois não tem nenhuma pessoa no 30 círculo de freqüência de contatos.

Assim deve ser procedido com as demais perguntas.

O tamanho da Rede de suporte social corresponde, dessa maneira, ao número de registros no Mapa Mínimo de Relaçōes, segundo a percepção do idoso. Além do tamanho, esse instrumento permite conhecer a amplitude dos relacionamentos significativos mencionados, por quadrante, ou seja, pela composição (símbolo e abreviaçōes), por círculo (freqüência de contatos) e por função desempenhada. 


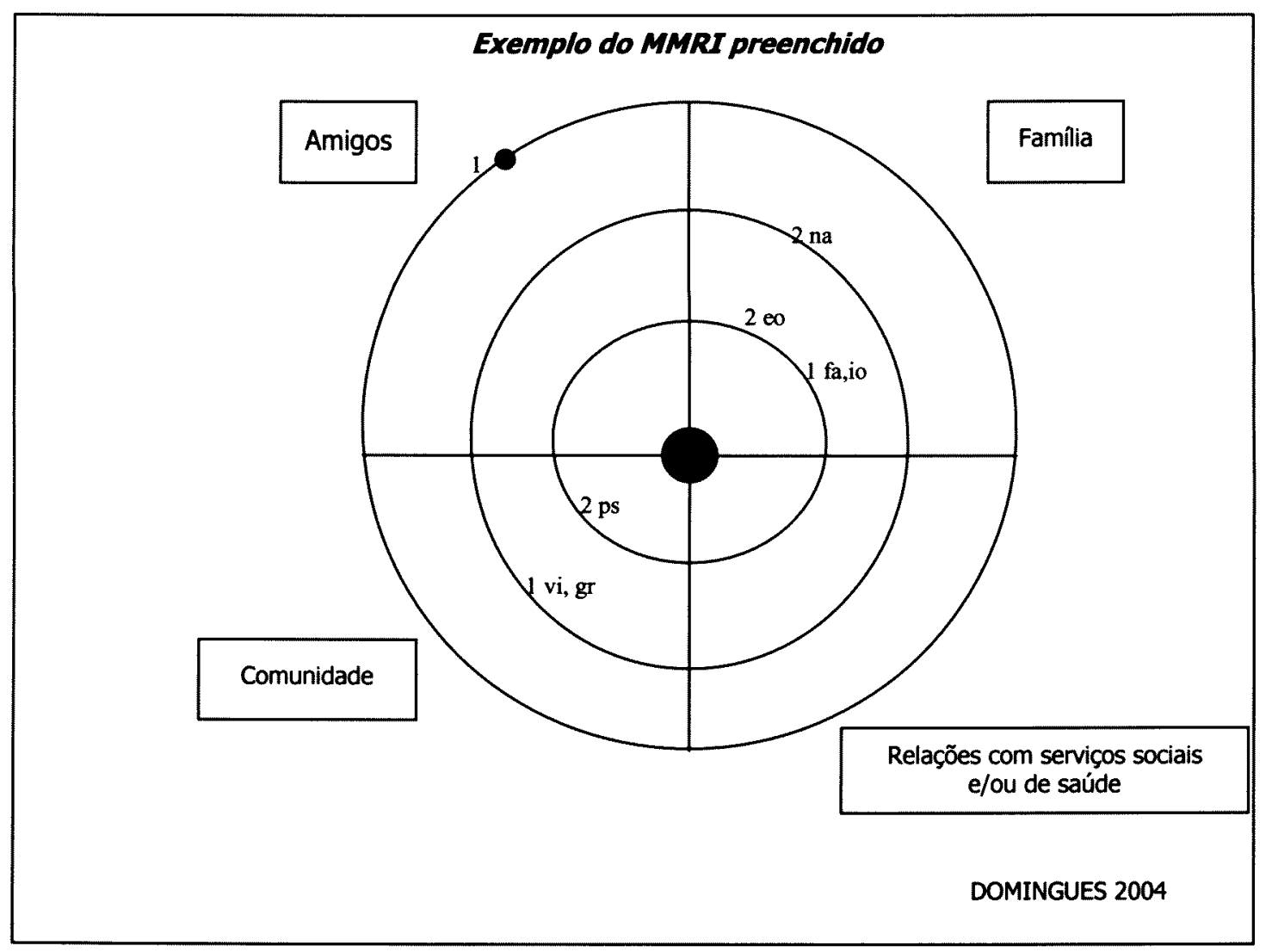




\section{MMRI - DADOS DE IDENTIFICAÇÃO}

Data da entrevista: ............................

Nome:

Sexo: Fem. ( ) Masc. ( )

Data de nascimento: ............................. Idade:

Endereço:

Bairro:

Fone:

1) Estado Conjugal:

Solteiro(a) ( )

Casado(a) ( )

Separado(a) ( )

Viúvo(a) ( )

Outros:

3) Há quanto tempo mora neste local: menos de um ano ()

de 1 a 5 anos ( )

de 6 a 10 anos ( )

de 11 a 15 anos ( )

de 16 a 19 anos ( )

mais de vinte anos ( )

\section{5)Tipo de moradia:}

Casa ( )

Apartamento ( )

Outros:
2) Quanto à convivência:

Reside sozinho(a)

$\operatorname{sim}($ )

não ( )

Se não, com quem reside:

Companheiro(a) ( ) Filho(a) ( ) Neto(a) ( )

Outros, quem:

4) Escolaridade:

Sem escolaridade ( )

$10 \mathrm{grau}$ incompleto ( )

$1^{\circ} \mathrm{grau}$ completo ( )

$2^{\circ} \mathrm{grau}$ incompleto ( )

$2^{\circ}$ grau completo ( )

Superior incompleto ( )

Superior completo ( )

\section{6) Vinculaçăo do imóvel:}

Próprio ( )

Alugado ( )

Cedido ( )

Outros: 
MMRI

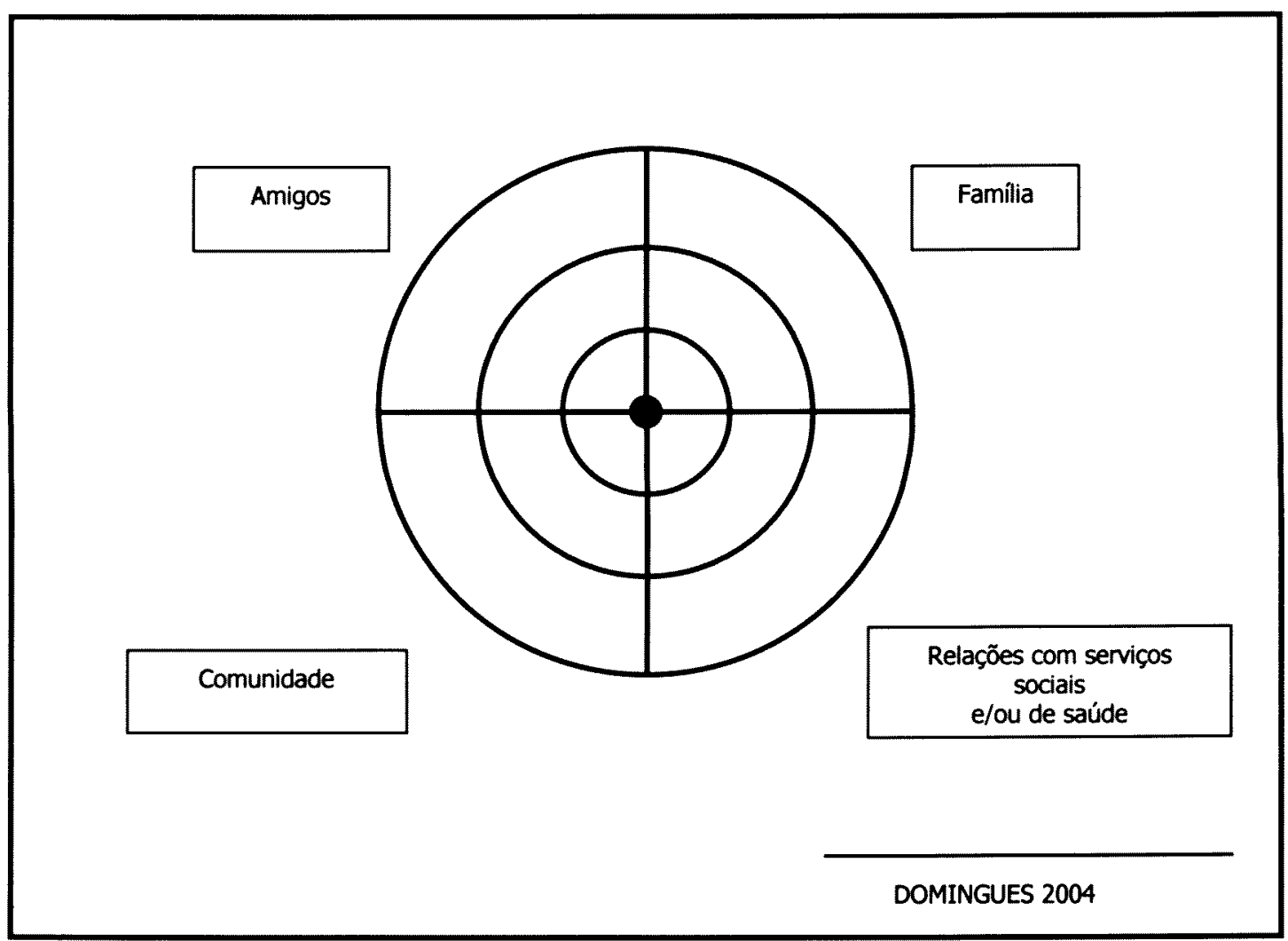

PERGUNTAS

FREQÜÊNCIA DE CONTATOS

1 - visita
2 - companhia
3 - auxílio para atividades domésticas
4 - auxílio para cuidados pessoais
5 - auxílio financeiro

10 Círculo $\curvearrowright$ ivez por semana/FREQËNTEMENTE $2^{\circ}$ Círculo $\$ 1$ vez por mês/POUCO FREQËNTEMENTE

$3^{\circ}$ Círculo $\curvearrowright 1$ vez por ano/RARAMENTE 
Abreviações/símbolo utilizados para o registro das respostas

\begin{tabular}{cll}
\hline $\begin{array}{c}\text { Amigos e Sistema } \\
\text { de Saúde }\end{array}$ & Famillia & Comunidade \\
\hline$\bullet$ & eo - esposo & $\mathrm{cc}$ - membros de centro de convivência \\
& ea - esposa & $\mathrm{c}$ - membros de clubes de lazer ou serviço \\
fa - filha & $\mathrm{gr}$ - membros de grupos religiosos \\
fo - filho & gt - membros de grupos de terceira idade \\
ia - irmã & ed - empregada doméstica \\
io - irmão & ps - prestadores de serviços \\
na - neta & vi - vizinhos \\
no - neto & 0 - outros \\
& 0 - outros & \\
\hline
\end{tabular}

\section{Observaçōes:}




\section{Perguntas a serem registradas no MMRI}

1) QUAIS AS PESSOAS QUE O(A) VISITAM, PELO MENOS:

- uma vez por semana (freqüentemente)?

- uma vez por mês (pouco freqüentemente)?

- e uma vez por ano (raramente)?

2) COM QUEM O(A) SENHOR(A) PODE CONTAR SE DESEJAR OU PRECISAR DE ALGUÉM PARA LHE FAZER COMPANHIA:

- uma vez por semana (freqüentemente)?

- uma vez por mês (pouco freqüentemente)?

- e uma vez por ano (raramente)?

3) A QUEM O(A) SENHOR(A) RECORRE OU RECORRERIA SE PRECISAR DE AJUDA PARA CUIDAR DAS COISAS DA CASA, COMO, POR EXEMPLO, ARRUMAR, LIMPAR, COZINHAR OU FAZER COMPRAS:

- uma vez por semana (freqüentemente)?

- uma vez por mês (pouco freqüentemente)?

- e uma vez por ano (raramente)?

4) A QUEM O(A) SENHOR(A) RECORRE OU RECORRERIA SE PRECISAR DE AUUDA PARA CUIDADOS PESSOAIS, COMO, POR EXEMPLO, TROCAR DE ROUPA, TOMAR BANHO, COMER, SE LEVANTAR, SE DEITAR:

- uma vez por semana (freqüentemente)?

- uma vez por mês (pouco freqüentemente)?

- e uma vez por ano (raramente)?

5) QUEM AJUDA OU AJUDARIA O(A) SENHOR(A) FINANCEIRAMENTE SE PRECISAR DE AUXÍLIO PARA PAGAR ALUGUEL DA SUA CASA, PAGAR UMA CONTA, COMPRAR COMIDA, REMÉDIO ETC.:

- uma vez por semana (freqüentemente)?

- uma vez por mês (pouco freqüentemente)?

- e uma vez por ano (raramente)? 


\section{APRESENTAÇÃO DOS RESULTADOS}

Passamos a apresentar o resultado das três fases de aplicação da técnica Delfos, obtido pelo consenso dos juízes consultados por meio de tabelas descritivas com as notas e sugestões recebidas para cada questão, as quais posteriormente serão ilustradas com figuras que expressam os resultados das medidas estatísticas de tendência central, média e mediana e de dispersão, desvio padrão.

\subsection{Apresentação dos dados relativos às notas, sugestões e observações relativas às perguntas sobre dados de identificação, visita ou companhia e auxílio para serviços domésticos na $1^{\text {a }}$ aplicação do MMRI}

\begin{tabular}{|c|c|c|c|}
\hline \multirow[t]{4}{*}{$\begin{array}{l}\text { JUIZESI } \\
\text { PERGUNTAS }\end{array}$} & \multirow{4}{*}{$\begin{array}{l}\text { As perguntas relativas aos dados } \\
\text { de identificaçäo estão apresenta- } \\
\text { das de forma bastante sucinta. } \\
\text { Com relação à clareza, dê uma nota } \\
\text { de } 1 \text { a } 5:(1 \text { total discordância; } \\
5 \text { total concordância). } \\
\text { Com relação à pertinência das } \\
\text { perguntas, dê uma nota de } 1 \text { a cinco: } \\
\text { (1 total discordância; } 5 \text { total } \\
\text { concordância). }\end{array}$} & \multirow{4}{*}{$\begin{array}{l}\text { 1) Quem o(a) visita ou lhe faz } \\
\text { companhia? } \\
\text { Com relação à clareza do enunciado, } \\
\text { dê uma nota de } 1 \text { a } 5: \text { ( } 1 \text { total } \\
\text { discordância; } 5 \text { total concordância) } \\
\text { Com relação à pertinência da } \\
\text { pergunta, dê uma nota de } 1 \text { a } 5: \\
\text { (1 total discordância; } 5 \text { total } \\
\text { concordância). } \\
\text { Com relação à forma de registro da } \\
\text { resposta no Mapa Mínimo, dê uma } \\
\text { nota de } 1 \text { a } 5: \text { (1 total discordância; } \\
5 \text { total concordância). }\end{array}$} & \multirow{4}{*}{$\begin{array}{l}\text { 2) Se o senhor(a) precisar de } \\
\text { auxilio para serviços domésticos } \\
\text { quem o(a) auxiliaria? } \\
\text { Com relação à clareza do enunciado, } \\
\text { dê uma nota de } 1 \text { a } 5 \text { : (1 total } \\
\text { discordância; } 5 \text { total concordância) } \\
\text { Com relaçăo à pertinência da } \\
\text { pergunta, dê uma nota de } 1 \text { a } 5: \\
\text { (1 total discordâncla; } 5 \text { total } \\
\text { concordâncla) } \\
\text { Com relação à forma de registro da } \\
\text { resposta no Mapa Mínimo, dê uma } \\
\text { nota de } 1 \text { a } 5: \text { : } 1 \text { total discordância; } \\
5 \text { total concordância) }\end{array}$} \\
\hline & & & \\
\hline & & & \\
\hline & & & \\
\hline $\begin{array}{l}\text { RUBI } \\
\text { Notas } \\
\text { Sugestões } \\
\text { Observações }\end{array}$ & $\begin{array}{l}\text { Com relação à clareza do enunciado } \\
\text { Nota: } 2 \\
\text { Sugestões: não há. } \\
\text { Quanto à pertinência das perguntas } \\
\text { Nota: } 3 \\
\text { Sugestões: Eu acho que tudo está } \\
\text { bem e pertinente, mas você deve } \\
\text { contemplar a possibilidade de que os } \\
\text { seus idosos não estejam restritos à } \\
\text { casa. } \\
\text { Observações: não há. }\end{array}$ & $\begin{array}{l}\text { Com relação à clareza do enunciado } \\
\text { Nota: } 3 \\
\text { Observações: Verfficar se este } \\
\text { formulário contempla apenas idosos } \\
\text { que estejam restritos à casa. } \\
\text { Quanto à pertinêncla das perguntas } \\
\text { Nota: } 5 \\
\text { Observaçães: É pertinente, mas não } \\
\text { esgota a amplitude da questão. } \\
\text { Quanto à forma de registro no MMRI } \\
\text { Nota: } 3 \\
\text { Observações: Pode ficar prejudicada } \\
\text { pela não-definição do critério de } \\
\text { proximidade e pela questão das } \\
\text { pausas. }\end{array}$ & $\begin{array}{l}\text { Com relação à clareza do enunciado } \\
\text { Nota: } 3 \\
\text { Sugestóes: Eu diria: se o senhor ou } \\
\text { senhora precisar de ajuda para cuidar } \\
\text { das colsas da casa, como, por } \\
\text { exemplo, arrumar, limpar, cozinhar } \\
\text { ou fazer compras, com quem acha } \\
\text { que pode contar? } \\
\text { Talvez seja interessante pensar em } \\
\text { possibilidades adicionais para tipos } \\
\text { de apoio. } \\
\text { Exs: Instrumental: fazer serviços de } \\
\text { casa; cozinhar/consertar/arrumar; } \\
\text { fazer compras, receber } \\
\text { pensão/aposentadoria//I ao banco; ir } \\
\text { ao médico; ir à igreja; fazer visitas; } \\
\text { passear/viajar. } \\
\text { Material: ajudar nas despesas da } \\
\text { casa; ajudar na compra de remédios; } \\
\text { comprar roupas; ajudar a pagar as } \\
\text { contas (aluguel, prestações, } \\
\text { impostos). } \\
\text { Afetivo: fazer companhia; conversar } \\
\text { sobre problemas de saúde; conversar } \\
\text { sobre a vida; conversar sobre } \\
\text { problemas de dinheiro; conversar } \\
\text { sobre assuntos pessoais/contar } \\
\text { coisas pessoais/contar segredos/fazer } \\
\text { confidencias; sair junto para fazer } \\
\text { visitas; sair junto para divertir-se. }\end{array}$ \\
\hline
\end{tabular}




\begin{tabular}{|l|l|l|}
\hline & & $\begin{array}{l}\text { Talvez seja preciso pensar em } \\
\text { ampliar as fontes de apolo, para } \\
\text { incluir, por exemplo, profissionais (o } \\
\text { médico, o padre? o pastor? a } \\
\text { professora?). } \\
\text { Quanto à pertinência das perguntas } \\
\text { Nota: } 5 \\
\text { Sugestões: não há. } \\
\text { Observações: não há. } \\
\text { Quanto à forma de registro no MMRI } \\
\text { Nota: } 3 \\
\text { Sugestões: ver anteriores. }\end{array}$ \\
\hline
\end{tabular}

\begin{tabular}{|c|c|c|c|}
\hline $\begin{array}{l}\text { TOPÁzIO } \\
\text { Notas } \\
\text { Sugestz̃es } \\
\text { Observações }\end{array}$ & $\begin{array}{l}\text { Com relação à clareza do enunciado } \\
\text { Nota: } 5 \\
\text { Sugestões: Um item sobre estado } \\
\text { civil } \\
\text { Quanto à pertinência das perguntas } \\
\text { Nota: } 5 \\
\text { Sugestőes: não há. }\end{array}$ & $\begin{array}{l}\text { Com relação à clareza do enunciado } \\
\text { Nota: } 5 \\
\text { Observaçð̃es: Se o idoso quer alguém } \\
\text { para conversar, desabafar, que o } \\
\text { ouça, que ele possa trocar idélas, } \\
\text { pontos de vista, como você val } \\
\text { saber? } \\
\text { Quanto à pertinência das perguntas } \\
\text { Nota: } 5 \\
\text { Sugestões e observações: não há. } \\
\text { Quanto à forma de registro no MMRI } \\
\text { Nota: } 5 \\
\text { Sugestz̃es e observaç̃es: não há. }\end{array}$ & $\begin{array}{l}\text { Com relação à clareza do enunciado } \\
\text { Nota: } 5 \\
\text { Sugestões e observações: não há. } \\
\text { Quanto à pertinência das perguntas } \\
\text { Nota: } 5 \\
\text { Sugestões e observações: não há. } \\
\text { Quanto à forma de registro no MMRI } \\
\text { Nota: } 5 \\
\text { Sugestões e observações: não há. }\end{array}$ \\
\hline
\end{tabular}

\begin{tabular}{|c|c|c|c|}
\hline $\begin{array}{l}\text { ÁGUA- } \\
\text { MARINHA } \\
\text { Notas } \\
\text { Sugestões } \\
\text { Observações }\end{array}$ & $\begin{array}{l}\text { Com relação à clareza do enunclado } \\
\text { Nota: } 5 \\
\text { Sugestões: não há. } \\
\text { Quanto à pertinência das perguntas } \\
\text { Nota: } 5 \\
\text { Observaçães: há necessidade de bom } \\
\text { esclarecimento a quem val aplicar o } \\
\text { mapa, no sentido de saber tudo o } \\
\text { que pode ser englobado pelo } \\
\text { método. }\end{array}$ & $\begin{array}{l}\text { Com relação à clareza do enunciado } \\
\text { Nota: } 3 \\
\text { Observaç̃es: Visita e companhia não } \\
\text { seriam situações diferentes? } \\
\text { Quanto à pertinência das perguntas } \\
\text { Nota: } 5 \\
\text { Sugestzes e observações: não há. } \\
\text { Quanto à forma de registro no MMRI } \\
\text { Nota: } 5 \\
\text { Sugestões e observações: não há. }\end{array}$ & $\begin{array}{l}\text { Com relação à dareza do enunciado } \\
\text { Nota: } 5 \\
\text { Sugestões: Gostaria de saber se } \\
\text { entre os prestadores de serviço estão } \\
\text { os empregados domésticos. } \\
\text { Quanto à pertinência das perguntas } \\
\text { Nota: } 5 \\
\text { Sugestões e observações: não há. } \\
\text { Quanto à forma de registro no MMRI } \\
\text { Nota: } 5 \\
\text { Sugestões e observações: não há. }\end{array}$ \\
\hline
\end{tabular}

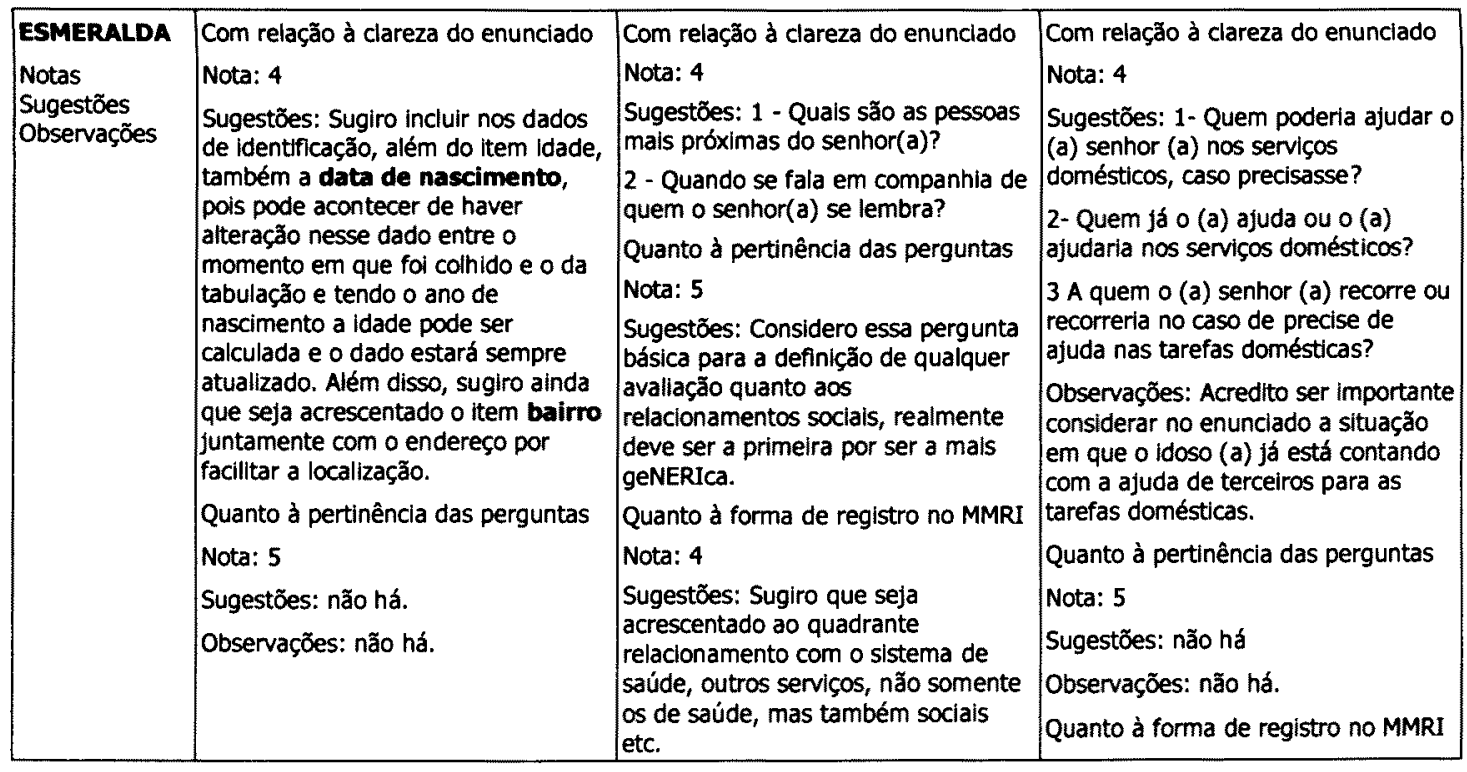




\begin{tabular}{|c|c|c|c|}
\hline & & & $\begin{array}{l}\text { Nota: } 5 \\
\text { Sugestões: não há. } \\
\text { Observações: não há. }\end{array}$ \\
\hline $\begin{array}{l}\text { JADE } \\
\text { Notas } \\
\text { Sugestões } \\
\text { Observações }\end{array}$ & $\begin{array}{l}\text { Quanto à clareza do enunciado } \\
\text { Nota: } 5 \\
\text { Sugestð̃es: Sugiro a inclusão da data } \\
\text { de nascimento do entrevistado. Isso } \\
\text { facilitaria o uso da informação em } \\
\text { pesquisa por falxa etária. } \\
\text { Observações: Não há. } \\
\text { Quanto à pertinência das perguntas } \\
\text { Nota: } 5 \\
\text { Sugestões: não há. } \\
\text { Observações: não há. }\end{array}$ & $\begin{array}{l}\text { Quanto à clareza do enunciado } \\
\text { Nota: } 4 \\
\text { Sugestões: Acho que esta questão } \\
\text { deveria ser transformada em duas. A } \\
\text { primeira: Quem Ihe faz companhia? A } \\
\text { segunda: Quem o visita? O idoso tem } \\
\text { dificuldades quando perguntamos } \\
\text { várias colsas ao mesmo tempo. } \\
\text { Observações: Não há. } \\
\text { Quanto à pertinência da pergunta } \\
\text { Nota: } 5 \\
\text { Sugestões: não há. } \\
\text { Observações: não há. } \\
\text { Quanto à forma de registro no MMRI } \\
\text { Nota: } 5 \\
\text { Sugestões: Não há. } \\
\text { Observaçס̃es: Não há. }\end{array}$ & $\begin{array}{l}\text { Quanto à clareza do enunciado } \\
\text { Nota: } 3 \\
\text { Sugestões: Não acho bom o uso do } \\
\text { condicional. Acho que as perguntas } \\
\text { devem ser diretas. O senhor precisa } \\
\text { de auxílio para trabalhos domésticos? } \\
\text { Se sim: Quem o ajuda? Se não, no } \\
\text { momento, quem acha que poderia } \\
\text { ajudá-lo caso necessite de ajuda? } \\
\text { Observações: Não há. } \\
\text { Quanto à pertinência da pergunta } \\
\text { Nota: } 5 \\
\text { Sugestões: Não há. } \\
\text { Observações: Não há. } \\
\text { Quanto à forma de registro no MMRI } \\
\text { Nota: } 5 \\
\text { Sugestões: Não há. } \\
\text { Observações: Não há. }\end{array}$ \\
\hline
\end{tabular}

\begin{tabular}{|c|c|c|c|}
\hline $\begin{array}{l}\text { SAFIRA } \\
\text { Notas } \\
\text { Sugestões } \\
\text { Observações }\end{array}$ & $\begin{array}{l}\text { Quanto à clareza do enunciado } \\
\text { Nota: } 4 \\
\text { Sugestões: Sugiro que os dados } \\
\text { relativos a endereço sejam mais } \\
\text { especificados, explicitando rua, } \\
\text { número, bairro e cidade. Lembro } \\
\text { também que falta a especificação de } \\
\text { gênero. } \\
\text { Quanto à pertinêncla das perguntas } \\
\text { Nota: } 5\end{array}$ & 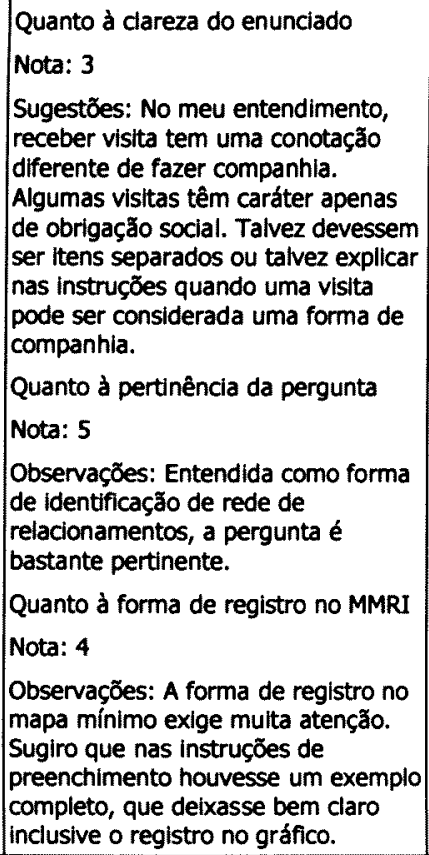 & $\begin{array}{l}\text { Quanto à clareza do enunciado } \\
\text { Nota: } 4 \\
\text { Sugestões: Seria interessante } \\
\text { acrescentar a elaboração de refeições } \\
\text { como exemplo de auxilio doméstico, } \\
\text { pols é diferente de allmentar o } \\
\text { paclente. } \\
\text { Quanto à pertinência da pergunta } \\
\text { Nota: } 5 . \\
\text { Observações: Auxilio doméstico é um } \\
\text { aspecto extremamente importante da } \\
\text { rede de atenção ao ldoso e de } \\
\text { suporte social. } \\
\text { Quanto à forma de registro no MMRI } \\
\text { Nota: } 4 \\
\text { Sugestões: Vale a observação da } \\
\text { questão anterior. }\end{array}$ \\
\hline
\end{tabular}




\begin{tabular}{|c|c|c|c|}
\hline $\begin{array}{l}\text { ONDX } \\
\text { Notas } \\
\text { Sugestões } \\
\text { Observações }\end{array}$ & $\begin{array}{l}\text { Com relação à dareza do enunciado } \\
\text { Nota: } 5 \\
\text { Sugestão: não há. } \\
\text { Observação: não há. } \\
\text { Quanto à pertinência das perguntas } \\
\text { Nota: } 5 \\
\text { Sugestão: não há. } \\
\text { Observação: não há. }\end{array}$ & $\begin{array}{l}\text { Com relação à clareza do enunciado } \\
\text { Nota: } 3 \\
\text { Sugestões: Alguém fica com o sr(a) } \\
\text { durante o dla? E à noite? Quem o } \\
\text { sr(a) vê todos os dias? Quem o sr(a) } \\
\text { encontra nos fins de semana? Quem } \\
\text { o sr(a) vê uma vez por mês? E só } \\
\text { uma vez por ano? } \\
\text { Observaçőes: Acredito que deva ficar } \\
\text { mais detalhado, desmembrada a } \\
\text { noção de visita. Também acredito ser } \\
\text { necessário Investigar os lugares que } \\
\text { costuma freqüentar diariamente e } \\
\text { quem encontra nesses lugares; } \\
\text { praça, porta de algum } \\
\text { estabelecimento comercial, lgreja, } \\
\text { grupo de terceira idade. } \\
\text { Quanto à pertinência da pergunta } \\
\text { Nota: } 5 \\
\text { Quanto à forma de registro no MMRI } \\
\text { Nota: } 5\end{array}$ & $\begin{array}{l}\text { Com relação à clareza do enunciado } \\
\text { Nota: } 3 \\
\text { Sugestões: O sr(a) consegue arrumar } \\
\text { suas roupas, seu quarto, limpar a } \\
\text { cozinha e o banhelro? O sr(a) vai no } \\
\text { mercado, no açougue, na padarla e } \\
\text { na farmácla? Alguém ajuda o sr(a) a } \\
\text { fazer essas coisas? } \\
\text { Observações: O "termo serviços } \\
\text { domésticos" fica mais bem } \\
\text { empregado se for detalhado em seus } \\
\text { significados. } \\
\text { Quanto à pertinência da pergunta } \\
\text { Nota: } 5 \\
\text { Quanto à forma de registro no MMRI } \\
\text { Nota: } 5\end{array}$ \\
\hline
\end{tabular}

\begin{tabular}{|c|c|c|c|}
\hline TURMALINA & Com relação à clareza do enunciado & Com relação d̀ clareza do enunciado & Com relação d̀ clareza do enunciado \\
\hline $\begin{array}{l}\text { Notas } \\
\text { Sugestöes } \\
\text { Observaçöes }\end{array}$ & $\begin{array}{l}\text { Nota: } 4 \\
\text { Sugestão: não há. } \\
\text { Observações: não há. } \\
\text { Quanto à pertinência das perguntas } \\
\text { Nota: } 4 \\
\text { Sugestð̃es: não há. }\end{array}$ & $\begin{array}{l}\text { Nota: } 5 \\
\text { Sugestão: Quem o visita durante a } \\
\text { semana, o mês ou o ano? } \\
\text { Observaçães: A freqüência da visita é } \\
\text { importante para a avaliação do } \\
\text { quanto o sujeito sente e pode contar } \\
\text { com o apolo da pessoa. } \\
\text { Quanto à pertinência da pergunta } \\
\text { Nota: } 5 \\
\text { Quanto à forma de registro no MMRI } \\
\text { Nota: } 4 \\
\text { Sugestões: Depende também da } \\
\text { regularidade e freqüência relatada. }\end{array}$ & $\begin{array}{l}\text { Nota: } 5 \\
\text { Quanto à pertinência das perguntas } \\
\text { Nota: } 5 \\
\text { Quanto à forma de registro no MMRI } \\
\text { Nota: } 5\end{array}$ \\
\hline
\end{tabular}

\begin{tabular}{|c|c|c|c|}
\hline $\begin{array}{l}\text { AGATA } \\
\text { Notas } \\
\text { Sugestōes } \\
\text { Observaçōes }\end{array}$ & $\begin{array}{l}\text { Com relação à dareza do enunciado } \\
\text { Nota: } 5 \\
\text { Quanto à pertinência das perguntas } \\
\text { Nota: } 4 \\
\text { Sugestőes: Acrescentar data de } \\
\text { nascimento. } \\
\text { Acrescentar consttulção familiar, } \\
\text { pensando em idosos residentes na } \\
\text { comunidade, no sentido de identificar } \\
\text { com quem o idoso reside. } \\
\text { Observaçães: Maior número de dados } \\
\text { de identificação permite melhor } \\
\text { visibilidade do contexto do idoso. }\end{array}$ & $\begin{array}{l}\text { Com relação à clareza do enunciado } \\
\text { Nota: } 3 \\
\text { Sugestōes: Separar a questão em } 2 \\
\text { Quem o visita? } \\
\text { Quem lhe faz companhia? } \\
\text { Observações: A visita pode ser } \\
\text { entendida tanto como multo } \\
\text { freqüente quanto pouco freqülente. } \\
\text { Companhia dá idéia de permanência } \\
\text { por maior período do dia. } \\
\text { Quanto à pertinência da pergunta } \\
\text { Nota: } 4 \\
\text { Observações: Embora seja } \\
\text { pertinente, como já mencionei } \\
\text { considero importante separar, se } \\
\text { possivel. } \\
\text { Quanto à forma de registro no MMRI } \\
\text { Nota: } 4\end{array}$ & $\begin{array}{l}\text { Com relaçăo à dareza do enunciado } \\
\text { Nota: } 5 \\
\text { Quanto à pertinêncla das perguntas } \\
\text { Nota: } 5 \\
\text { Quanto à forma de registro no MMRI } \\
\text { Nota: } 5\end{array}$ \\
\hline
\end{tabular}




\begin{tabular}{|c|c|c|c|}
\hline $\begin{array}{l}\text { OPALA } \\
\text { Notas } \\
\text { Sugestões } \\
\text { Observações }\end{array}$ & $\begin{array}{l}\text { Com relação à clareza do enunciado } \\
\text { Nota: } 5 \\
\text { Sugestões: Dúvidas: Quando for um } \\
\text { amigo o próprio vizinho no lugar de } \\
\text { ponto poderia usar-se as siglas Pe. } \\
\text { Vi? } \\
\text { Quanto à pertinência das perguntas } \\
\text { Nota: } 5 \\
\text { Sugestð̃es: não há. } \\
\text { Observações: não há. }\end{array}$ & $\begin{array}{l}\text { Com relação à clareza do enunciado } \\
\text { Nota: } 5 \\
\text { Sugestões: não há. } \\
\text { Observações: não há. } \\
\text { Quanto à pertinêncla das perguntas } \\
\text { Nota: } 5 \\
\text { Sugestões: não há. } \\
\text { Observações: não há. } \\
\text { Quanto à forma de registro no MMRI } \\
\text { Nota: } 5 \\
\text { Sugestões: não há. } \\
\text { Observacões: não há. }\end{array}$ & $\begin{array}{l}\text { Com relação à clareza do enunciado } \\
\text { Nota: } 5 \\
\text { Sugestões: não há. } \\
\text { Observações: não há. } \\
\text { Quanto à pertinêncla das perguntas } \\
\text { Nota: } 5 \\
\text { Sugestões: não há. } \\
\text { Observações: não há. } \\
\text { Quanto à forma de registro no MMRI } \\
\text { Nota: } 5 \\
\text { Sugestões: não há. } \\
\text { Observacões: não há. }\end{array}$ \\
\hline
\end{tabular}

\subsection{Apresentação dos dados relativos às notas, sugestões e observações relativas às perguntas sobre auxílio para cuidados pessoais, auxílio financeiro e quanto a apresentação gráfica do instrumento na $1^{\text {a }}$ aplicação do MMRI}

\begin{tabular}{|c|c|c|c|}
\hline \multirow[t]{4}{*}{$\begin{array}{l}\text { JUÍZES/ } \\
\text { PERGUNTAS }\end{array}$} & \multirow{2}{*}{$\begin{array}{l}\text { 3) Se o senhor(a) precisar de } \\
\text { auxilio para cuidados pessoais, } \\
\text { quem o (a)auxiliaria? } \\
\text { Com relação à clareza do enunciado, } \\
\text { dê uma nota de } 1 \text { a } 5 \text { : ( } 1 \text { total } \\
\text { discordância; } 5 \text { total concordância) }\end{array}$} & \multirow{2}{*}{$\begin{array}{l}\text { 4) Se o senhor(a) precisar de } \\
\text { auxilio financeiro quem o (a) } \\
\text { auxiliaria? } \\
\text { Com relação à clareza do enunciado, } \\
\text { dê uma nota de } 1 \text { a } 5 \text { : (1 total } \\
\text { discordâncla; } 5 \text { total concordâncla) }\end{array}$} & \multirow{4}{*}{$\begin{array}{l}\text { 5) Quanto à apresentaçăo } \\
\text { gráfica do instrumento } \\
\text { Com relação à adequação do MMRI, } \\
\text { dê uma nota de } 1 \text { a } 5: \text { ( } 1 \text { total } \\
\text { discordância; } 5 \text { total concordâncla) }\end{array}$} \\
\hline & & & \\
\hline & $\begin{array}{l}\text { Com relação à pertinência da } \\
\text { pergunta, dê uma nota de } 1 \text { a 5: (1 } \\
\text { total discordância; } 5 \text { total } \\
\text { concordância) }\end{array}$ & $\begin{array}{l}\text { Com relação à pertinência da } \\
\text { pergunta, dê uma nota de } 1 \text { a 5: (1 } \\
\text { total discordância; } 5 \text { total } \\
\text { concordância) }\end{array}$ & \\
\hline & $\begin{array}{l}\text { Com relação à forma de registro da } \\
\text { resposta no Mapa Mínimo, dế uma } \\
\text { nota de } 1 \text { a } 5: \text { : (1 total discordância; } \\
5 \text { total concordância) }\end{array}$ & $\begin{array}{l}\text { Com relação à forma de registro da } \\
\text { resposta no Mapa Mínimo, dê uma } \\
\text { nota de } 1 \text { a } 5: \text { : (1 total discordância; } \\
5 \text { total concordância) }\end{array}$ & \\
\hline $\begin{array}{l}\text { RUBI } \\
\text { Notas } \\
\text { Sugestões } \\
\text { Observações }\end{array}$ & $\begin{array}{l}\text { Com relação à clareza do enunciado } \\
\text { Nota: } 3 \\
\text { Sugestz̃es: Acho que cuidados } \\
\text { pessoais é um pouco difícil. Eu diria: } \\
\text { Se por acaso o senhor ficar doente, } \\
\text { com que acha que pode contar para } \\
\text { ajudá-lo, por exemplo, para trocar de } \\
\text { roupa, tomar banho, deltar-se e } \\
\text { levantar-se, andar, comer e outras } \\
\text { atividades de cuidado pessoal? } \\
\text { Quanto à pertinência da pergunta } \\
\text { Nota: } 5 \\
\text { Sugestões: não há. } \\
\text { Observaçōes: não há. } \\
\text { Quanto à forma de registro no MMRI } \\
\text { Nota: } 3 \\
\text { Observações: Idem anteriores. }\end{array}$ & $\begin{array}{l}\text { Com relação à clareza do enunciado } \\
\text { Nota: } 3 \\
\text { Sugestões: Eu exemplificarla } \\
\text { Quanto à pertinêncla das perguntas } \\
\text { Nota: } 5 \\
\text { Sugestões: não há. } \\
\text { Observações: não há. } \\
\text { Quanto à forma de registro no MMRI } \\
\text { Nota: } 5 \\
\text { Sugestões: não há. } \\
\text { Observações: não há. } \\
\end{array}$ & $\begin{array}{l}\text { Com relação à adequação do MMRI } \\
\text { Nota: } 5 \\
\text { Observações: Eu acho que o conceito } \\
\text { é bom e funcional, mas você precisa } \\
\text { aprimorar e esclarecer a forma de } \\
\text { apresentar aos sujeitos. } \\
\text { Orientar o entrevistador para que } \\
\text { anote os códigos das respostas em } \\
\text { sentido horário - é para que não se } \\
\text { perca nas próprias anotações e para } \\
\text { criar um sistema para o seu próprio } \\
\text { controle. } \\
\text { Orientá-lo para a eventualidade de } \\
\text { que o pesquisado diga prenomes - } \\
\text { nesse caso, ele deverá perguntar o } \\
\text { que o senhor ou senhora é dele } \\
\text { ou dela? } \\
\text { Orientá-lo para que mostre o } \\
\text { diagrama e explique com clareza o } \\
\text { que ele representa na rede de } \\
\text { relações e que ele está no centro } \\
\text { dessa rede ou diagrama. }\end{array}$ \\
\hline
\end{tabular}




\begin{tabular}{|l|l|l|}
\hline & & $\begin{array}{l}\text { Talvez seja melhor mostrar primeiro } \\
\text { um desenho, só com os circulos, para } \\
\text { que o idoso compreenda bem a idéia } \\
\text { de que deve dar informaçōes sobre o } \\
\text { grau de proximidade, que deve ser } \\
\text { multo bem esciarecido e combinado, } \\
\text { para que cada um nazo entenda uma } \\
\text { coisa. Cuidado com a idéia de } \\
\text { proximidade, porque alguns podem } \\
\text { entender que é geográfica. Resolver } \\
\text { quem vai decidir qual o critério de } \\
\text { proximidade. }\end{array}$ \\
\hline
\end{tabular}

\begin{tabular}{|c|c|c|c|}
\hline $\begin{array}{l}\text { TOPkzzo } \\
\text { Notas } \\
\text { Sugestőes } \\
\text { Observaç̋̃es }\end{array}$ & $\begin{array}{l}\text { Com relação à clareza do enunciado } \\
\text { Nota: } 5 \\
\text { Sugestões e observações: não há. } \\
\text { Quanto à pertinência das perguntas } \\
\text { Nota: } 5 \\
\text { Sugestð̋es e observações: não há. } \\
\text { Quanto à forma de registro no MMRI } \\
\text { Nota: } 5 \\
\text { Sugestర̃es e observaçס̃es: não há. }\end{array}$ & $\begin{array}{l}\text { Com relação à clareza do enunciado } \\
\text { Nota: } 1 \\
\text { Sugestð̃es e observações: não há. } \\
\text { Quanto à pertinência das perguntas } \\
\text { Nota: } 1 \\
\text { Sugestőes e observações: não há } \\
\text { Quanto à forma de registro no MMRI } \\
\text { Nota: } 1 \\
\text { Sugestőes e observações: não há. }\end{array}$ & $\begin{array}{l}\text { Com relação à adequaçăo do MMRI } \\
\text { Nota: } 5 .\end{array}$ \\
\hline
\end{tabular}

\begin{tabular}{|c|c|c|c|}
\hline $\begin{array}{l}\text { AGUA- } \\
\text { MARIMHA } \\
\text { Notas } \\
\text { Sugestōes } \\
\text { Observaçōes }\end{array}$ & $\begin{array}{l}\text { Com relação à dareza do enunciado } \\
\text { Nota: } 4 \\
\text { Sugestóes: Reforço a pergunta } \\
\text { anterior: Engloba também cuidador } \\
\text { de saúde? Não seria importante } \\
\text { saber quem seria procurado para } \\
\text { auxiliá-to nos problemas de saúde? } \\
\text { Perguntas mais objetivas. Gostaria de } \\
\text { saber o que seriam os cuidados } \\
\text { pessoals: higiene, alimentaçăo ou } \\
\text { também englobariam os cuidados de } \\
\text { saúde? } \\
\text { Quanto à pertinência das perguntas } \\
\text { Nota: } 5 \\
\text { Sugestóes e observaçōes: não há. } \\
\text { Quanto à forma de registro no MMRI } \\
\text { Nota: } 5 \\
\text { Sugestões e observaçöes: não há. }\end{array}$ & $\begin{array}{l}\text { Com relaçăo à clareza do enundiado } \\
\text { Nota: } 5 \\
\text { Sugestões e observaçōes: não há. } \\
\text { Quanto à pertinénda das perguntas } \\
\text { Nota: } 5 \\
\text { Sugestões e observações: não há. } \\
\text { Quanto à forma de registro no MMRI } \\
\text { Nota: } 5 \\
\text { Sugestões e observações: não há. }\end{array}$ & $\begin{array}{l}\text { Com relação à adequação do MMRI } \\
\text { Nota: } 5 \\
\text { Observaçס̄es: Gostei do Mapa. Acho } \\
\text { que necessita de uma explicação } \\
\text { mais consistente e detalhada em } \\
\text { relação a cada uma das perguntas. }\end{array}$ \\
\hline
\end{tabular}

\begin{tabular}{|c|c|c|c|}
\hline $\begin{array}{l}\text { ESMERALDA } \\
\text { Notas } \\
\text { Sugestz̃es } \\
\text { Observaçס̃es }\end{array}$ & 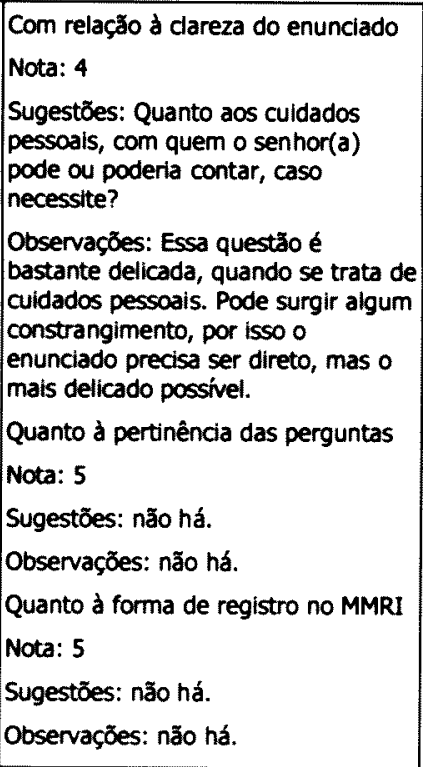 & 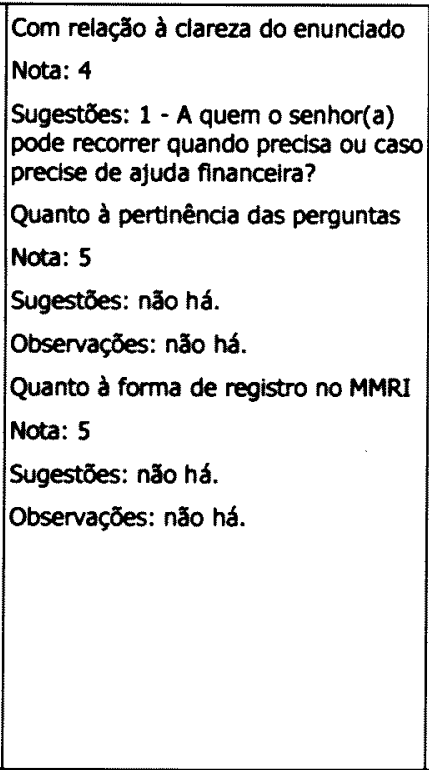 & 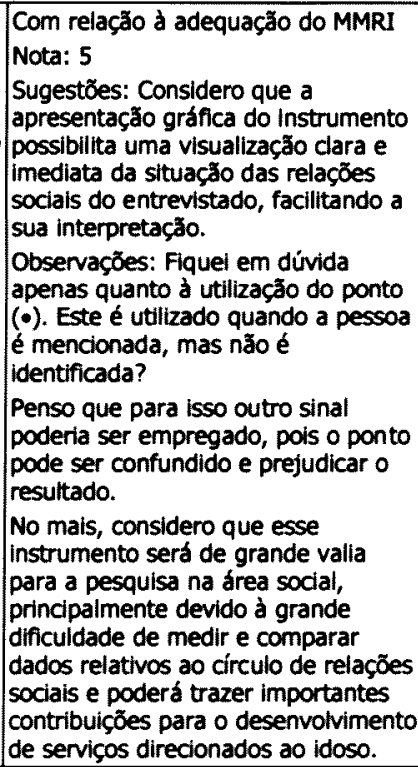 \\
\hline
\end{tabular}




\begin{tabular}{|c|c|c|c|}
\hline $\begin{array}{l}\text { JADE } \\
\text { Notas } \\
\text { Sugestões } \\
\text { Observações }\end{array}$ & $\begin{array}{l}\text { Quanto à clareza do enunciado } \\
\text { Nota: } 3 \\
\text { Sugestões: Prefiro sempre a pergunta } \\
\text { direta. O senhor precisa de auxillo } \\
\text { para...? } \\
\text { Quem o auxilia? Quem poderia } \\
\text { auxillá-lo caso precisasse? } \\
\text { Observaçães: Não há. } \\
\text { Quanto à pertinência da pergunta } \\
\text { Nota: } 5 \\
\text { Sugestões: Não há. } \\
\text { Observações: Não há. } \\
\text { Quanto à forma de registro no MMRI } \\
\text { Nota: } 5 \\
\text { Sugestões: Não há. } \\
\text { Observações: Não há. }\end{array}$ & $\begin{array}{l}\text { Quanto à clareza do enunciado } \\
\text { Nota: } 3 \\
\text { Sugestões: O senhor precisa de } \\
\text { auxílio financeiro? Quem poderia } \\
\text { ajudá-lo em caso de necessidade? } \\
\text { Observaçz̃es: Não há. } \\
\text { Quanto à pertinência da pergunta } \\
\text { Nota: } 5 \\
\text { Sugestões: Não há. } \\
\text { Observações: Não há. } \\
\text { Quanto à forma de registro no MMRI } \\
\text { Nota: } 5 \\
\text { Sugestões: Não há. } \\
\text { Observaçర̃es: Não há. }\end{array}$ & 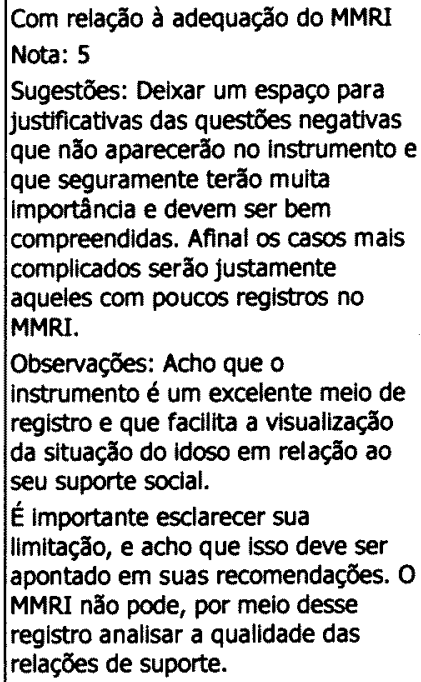 \\
\hline
\end{tabular}

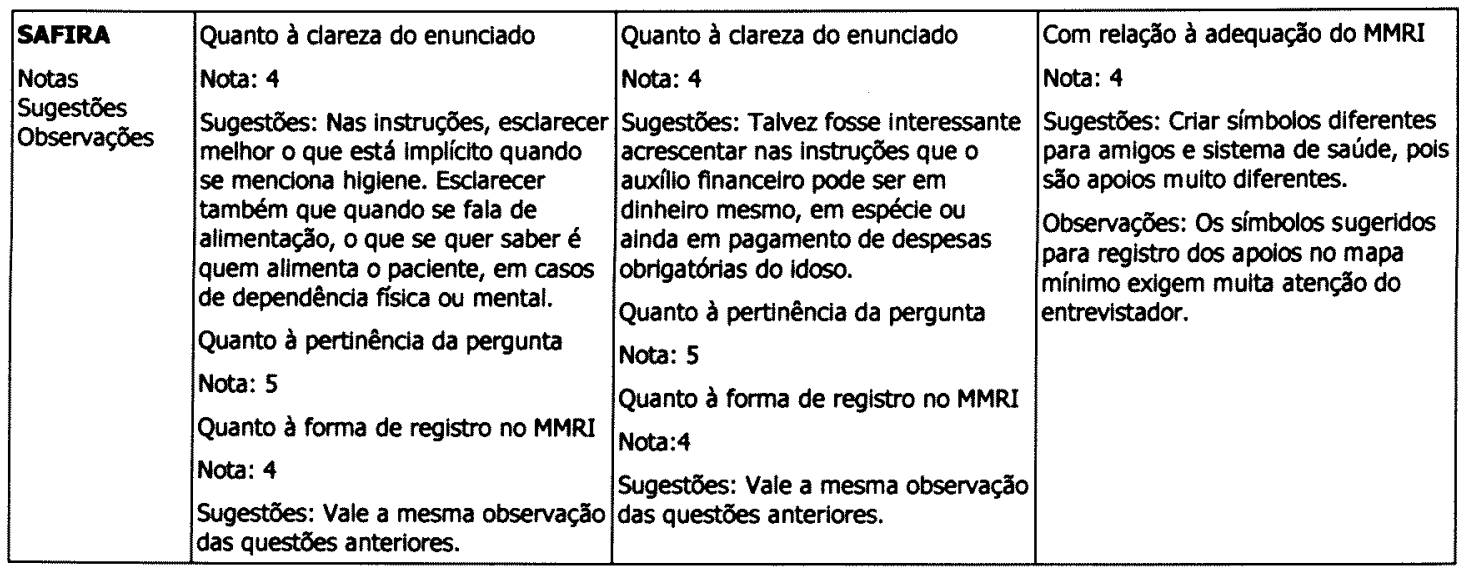

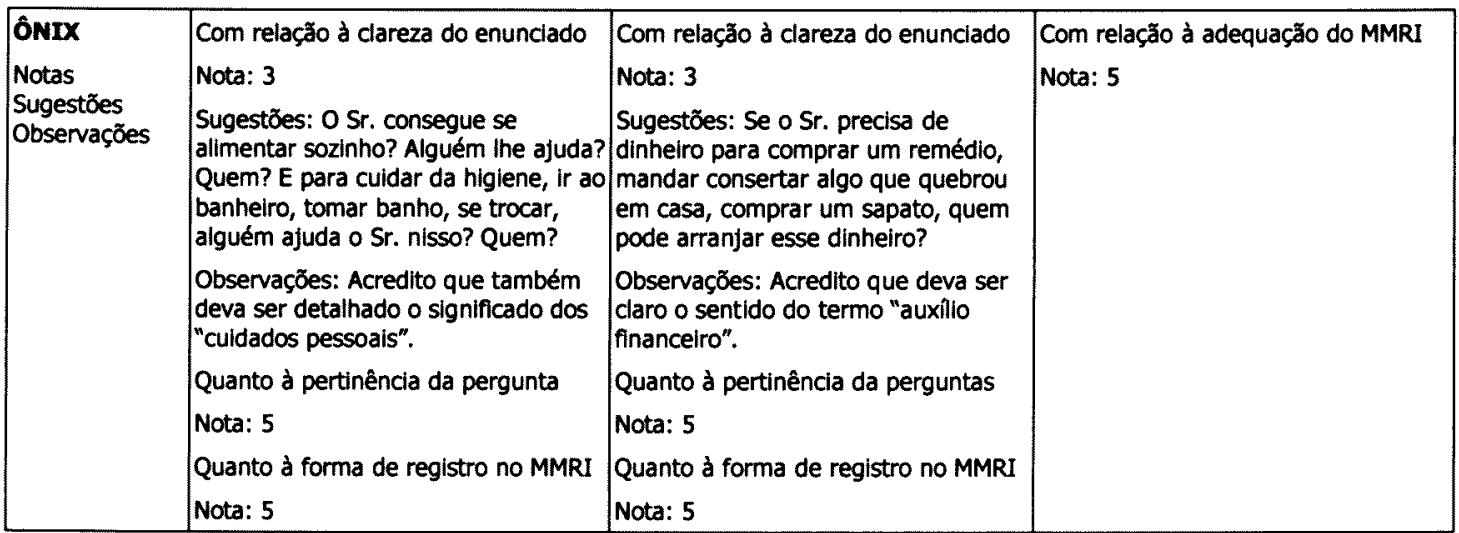

\begin{tabular}{|c|c|c|c|}
\hline $\begin{array}{l}\text { TURMALIMA } \\
\text { Notas } \\
\text { Sugestōes } \\
\text { Observaçöes }\end{array}$ & $\begin{array}{l}\text { Com relação à clareza do enunciado } \\
\text { Nota: } 4 \\
\text { Sugestões: O tempo do verto pode } \\
\text { ser: quem o tem auxillado. } \\
\text { Quanto à pertinência das perguntas } \\
\text { Nota: } 5 \\
\text { Quanto à forma de registro no MMRI } \\
\text { Nota: } 5\end{array}$ & $\begin{array}{l}\text { Com relação à clareza do enunciado } \\
\text { Nota: } 5 \\
\text { Quanto à pertinência das perguntas } \\
\text { Nota: } 5 \\
\text { Quanto à forma de registro no MMRI } \\
\text { Nota: } 5\end{array}$ & $\begin{array}{l}\text { Com relação à adequação do MMRI } \\
\text { Nota: } 4 \\
\text { Observaçб̃es: É importante saber } \\
\text { como tem sido exercidas tais funç̧̃es } \\
\text { ao longo do tempo e como o sujeito } \\
\text { tem recebido tais ajudas. Considero } \\
\text { também importante saber se ele } \\
\text { sente que pode haver reciprocidade } \\
\text { de alguma forma nestas relações de } \\
\text { apolo mútuo, o que implicaria em } \\
\text { maior auto-estima e capacidade de } \\
\text { recebimento de ajuda, com menor } \\
\text { sentimento de menos-valia }\end{array}$ \\
\hline
\end{tabular}




\begin{tabular}{|l|l|l|l|}
\hline ÁGATA & Com relação à clareza do enunciado & Com relação à clareza do enunciado & Com relação à adequação do MMRI \\
Notas & Nota: 4 & Nota: 5 & Nota: 4 \\
Sugestões & Sugestões: Deixar entre parênteses, \\
Observações & $\begin{array}{l}\text { Quanto à pertinência das perguntas } \\
\text { incluídas nos cuidados pessoais. } \\
\text { Quanto à pertinência das perguntas } \\
\text { Nota: } 5\end{array}$ & $\begin{array}{l}\text { Sugestões: Incluir questão relativa à } \\
\text { identificação da pessoa que } \\
\text { acompanha o(a) idoso(a) quando } \\
\text { Quanto à forma de registro no MMRI } \\
\text { necessita sair de casa (consulta } \\
\text { médica, exames, ida ao banco). } \\
\text { Quanto à forma de registro no MMRI } 5 \\
\text { Nota: } 5\end{array}$ & \\
\hline
\end{tabular}

\begin{tabular}{|c|c|c|c|}
\hline $\begin{array}{l}\text { OPALA } \\
\text { Notas } \\
\text { Sugestões } \\
\text { Observaçōes }\end{array}$ & $\begin{array}{l}\text { Com relação à clareza do enunciado } \\
\text { Nota: } 5 \\
\text { Sugestões: não há. } \\
\text { Observações: não há. } \\
\text { Quanto à pertinêncla das perguntas } \\
\text { Nota: } 5 \\
\text { Sugestões: não há. } \\
\text { Observações: não há. } \\
\text { Quanto à forma de registro no MMRI } \\
\text { Nota: } 5 \\
\text { Sugestões: não há. } \\
\text { Observações: não há. }\end{array}$ & $\begin{array}{l}\text { Com relação à clareza do enunciado } \\
\text { Nota: } 5 \\
\text { Sugestões: não há. } \\
\text { Observações: não há. } \\
\text { Quanto à pertinência das perguntas } \\
\text { Nota: } 5 \\
\text { Sugestões: não há. } \\
\text { Observações: não há. } \\
\text { Quanto à forma de registro no MMRI } \\
\text { Nota: } 5 \\
\text { Sugestões: não há. } \\
\text { Observaçס̃es: não há. }\end{array}$ & $\begin{array}{l}\text { Com relação à adequação do MMRI } \\
\text { Nota: } 5 \\
\text { Sugestőes: não há. } \\
\text { Observações: não há. }\end{array}$ \\
\hline
\end{tabular}

\subsection{Apresentação dos dados relativos à $1^{\mathrm{a}}$ aplicação do instrumento, segundo a Escala de Lickert}

Para a elaboração dessa análise, as notas dadas pelos juízes, para cada questão do MMRI, corresponderam a um conceito assim definido:

1 - discordo totalmente

2 - discordo parcialmente

3 - indeciso

4 - concordo parcialmente

5 - concordo totalmente 
1) Apresentação dos dados relativos à clareza da pergunta sobre os dados de identificação, na $1^{\text {a }}$ aplicação do MMRI, segundo escala de Lickert:

\begin{tabular}{|l|c|}
\hline \multicolumn{1}{|c|}{ Nota/Conceitos } & Freqüência \\
\hline 1 - Discordo totalmente & 0 \\
\hline 2 - Discordo parcialmente & 1 \\
\hline 3 - Indeciso & 0 \\
\hline 4 - Concordo parcialmente & 3 \\
\hline 5 - Concordo totalmente & 6 \\
\hline$n=10$
\end{tabular}

CONCORDÂNCIA TOTAL $=60 \%$

2) Apresentação dos dados relativos à pertinência da pergunta sobre dados de identificação, na $1^{\text {a }}$ aplicação do MMRI, segundo escala de Lickert:

\begin{tabular}{|l|c|}
\hline \multicolumn{1}{|c|}{ Nota/Conceitos } & Freqüência \\
\hline 1 - Discordo totalmente & 0 \\
\hline 2 - Discordo parcialmente & 0 \\
\hline 3 - Indeciso & 1 \\
\hline 4 - Concordo parcialmente & 2 \\
\hline 5 - Concordo totalmente & 7 \\
\hline$n=10$
\end{tabular}

CONCORDÂNCIA TOTAL $=70 \%$

\section{PERGUNTAS REFERENTES AO MMRI EM SUA 1a APLICAÇÃO}

1) Apresentação dos dados relativos à clareza da pergunta de $n^{\circ} 1$ do MMRI Quem o(a) visita ou lhe faz companhia -, na $1^{\text {a }}$ aplicação do MMRI, segundo escala de Lickert:

\begin{tabular}{|l|c|}
\hline \multicolumn{1}{|c|}{ Nota/Conceito } & Freqüência \\
\hline 1 - Discordo totalmente & 0 \\
\hline 2 - Discordo parcialmente & 0 \\
\hline 3 - Indeciso & 5 \\
\hline 4 - Concordo parcialmente & 2 \\
\hline 5 - Concordo totalmente & 3 \\
\hline$n=10$
\end{tabular}

CONCORDÂNCIA TOTAL $=30 \%$

INDECISOS $=\mathbf{5 0} \%$ 
2) Apresentação dos dados relativos à pertinência da pergunta de $\mathrm{n}^{\circ} 1$ do MMRI Quem o(a) visita ou lhe faz companhia -, na $1^{\text {a }}$ aplicação do MMRI, segundo escala de Lickert:

\begin{tabular}{|l|c|}
\hline \multicolumn{1}{|c|}{ Nota/Conceito } & Freqüência \\
\hline 1 - Discordo totalmente & 0 \\
\hline 2 - Discordo parcialmente & 0 \\
\hline 3 - Indeciso & 0 \\
\hline 4 - Concordo parcialmente & 1 \\
\hline 5 - Concordo totalmente & 9 \\
\hline
\end{tabular}

$n=10$

CONCORDÂNCIA TOTAL $=90 \%$

3) Apresentação dos dados relativos ao registro da pergunta de $n^{\circ} 1$ no MMRI Quem o(a) visita ou lhe faz companhia -, na $1^{\text {a }}$ aplicação do MMRI, segundo escala de Lickert:

\begin{tabular}{|l|c|}
\hline \multicolumn{1}{|c|}{ Nota/Conceito } & Freqüência \\
\hline 1 - Discordo totalmente & 0 \\
\hline 2 - Discordo parcialmente & 0 \\
\hline 3 - Indeciso & 1 \\
\hline 4 - Concordo parcialmente & 4 \\
\hline 5 - Concordo totalmente & 5 \\
\hline
\end{tabular}

$\mathrm{n}=10$

CONCORDÂNCIA TOTAL $=50 \%$

4) Apresentação dos dados relativos à clareza da pergunta de $n^{\circ} 2$ do $\mathrm{MMRI}-\mathrm{Se}$ o senhor(a) precisar de auxílio para serviços domésticos, quem o(a) auxiliaria -, na $1^{\mathrm{a}}$ aplicação do MMRI, segundo escala de Lickert:

\begin{tabular}{|l|c|}
\hline \multicolumn{1}{|c|}{ Nota/Conceito } & Freqüência \\
\hline 1 - Discordo totalmente & 0 \\
\hline 2 - Discordo parcialmente & 0 \\
\hline 3 - Indeciso & 3 \\
\hline 4 - Concordo parcialmente & 2 \\
\hline 5 - Concordo totalmente & 5 \\
\hline
\end{tabular}

$$
n=10
$$

CONCORDÂNCIA TOTAL $=50 \%$ 
5) Apresentação dos dados relativos à pertinência da pergunta de $\mathrm{n}^{\circ} 2$ do $\mathrm{MMRI}$ Se o senhor(a) precisar de auxílio para serviços domésticos quem o(a) auxiliaria -, na $1^{\mathrm{a}}$ aplicação do MMRI, segundo escala de Lickert:

\begin{tabular}{|l|c|}
\hline \multicolumn{1}{|c|}{ Nota/Conceito } & Freqüência \\
\hline 1 - Discordo totalmente & 0 \\
\hline 2 - Discordo parcialmente & 0 \\
\hline 3 - Indeciso & 0 \\
\hline 4 - Concordo parcialmente & 0 \\
\hline 5 - Concordo totalmente & 10 \\
\hline
\end{tabular}

$\mathrm{n}=10$

CONCORDÂNCIA TOTAL $=100 \%$

6) Apresentação dos dados relativos ao registro da pergunta de $n^{\circ} 2$ no MMRI Se o senhor(a) precisar de auxílio para serviços domésticos quem o(a) auxiliaria -, na $1^{\text {a }}$ aplicação do MMRI, segundo escala de Lickert:

\begin{tabular}{|l|c|}
\hline \multicolumn{1}{|c|}{ Nota/Conceito } & $N^{0}$ de Respostas \\
\hline 1 - Discordo totalmente & \\
\hline 2 - Discordo parcialmente & \\
\hline 3 - Indeciso & 1 \\
\hline 4 - Concordo parcialmente & 1 \\
\hline 5 - Concordo totalmente & 8 \\
\hline$n=10$
\end{tabular}

CONCORDÂNCIA TOTAL $=80 \%$

7) Apresentação dos dados relativos à clareza da pergunta de $\mathrm{n}^{\circ} 3$ do $\mathrm{MMRI}-\mathrm{Se}$ o senhor(a) precisar de auxílio para cuidados pessoais quem o(a) auxiliaria -, na $1^{\text {a }}$ aplicação do MMRI, segundo escala de Lickert:

\begin{tabular}{|c|c|}
\hline Nota/Conceitos & Freqüência \\
\hline 1 - Discordo totalmente & $\mathbf{0}$ \\
\hline 2 - Discordo parcialmente & $\mathbf{0}$ \\
\hline 3 - Indeciso & 3 \\
\hline 4 - Concordo parcialmente & 5 \\
\hline 5 - Concordo totalmente & 2 \\
\hline \multicolumn{2}{|l|}{$n=10$} \\
\hline CONCORDÂNCIA TOTAL $=2$ & \\
\hline
\end{tabular}


8) Apresentação dos dados relativos à pertinência da pergunta de $\mathrm{n}^{0} 3$ do $\mathrm{MMRI}$ Se o senhor(a) precisar de auxílio para cuidados pessoais quem o(a) auxiliaria -, na $1^{\text {a }}$ aplicação do MMRI, segundo escala de Lickert:

\begin{tabular}{|l|c|}
\hline \multicolumn{1}{|c|}{ Nota/Conceito } & Freqüência \\
\hline 1 - Discordo totalmente & 0 \\
\hline 2 - Discordo parcialmente & 0 \\
\hline 3 - Indeciso & 0 \\
\hline 4 - Concordo parcialmente & 0 \\
\hline 5 - Concordo totalmente & 10 \\
\hline$n=10$
\end{tabular}

CONCORDÂNCIA TOTAL $=100 \%$

9) Apresentação dos dados relativos ao registro da pergunta de $n^{\circ} 3$ no MMRI Se o senhor(a) precisar de auxílio para cuidados pessoais quem o(a) auxiliaria -, na $1^{\text {a }}$ aplicação do MMRI, segundo escala de Lickert:

\begin{tabular}{|l|c|}
\hline \multicolumn{1}{|c|}{ Nota/Conceito } & Freqüência \\
\hline 1 - Discordo totalmente & 0 \\
\hline 2 - Discordo parcialmente & 0 \\
\hline 3 - Indeciso & 1 \\
\hline 4 - Concordo parcialmente & 1 \\
\hline 5 - Concordo totalmente & 8 \\
\hline$n=10$
\end{tabular}

CONCORDÂNCIA TOTAL $=\mathbf{8 0} \%$

10) Apresentação dos dados relativos à clareza da pergunta de $n^{\circ} 4$ do $\mathrm{MMRI}-\mathrm{Se}$ o senhor(a) precisar de auxílio financeiro quem o(a) auxiliaria -, na $1^{\mathrm{a}}$ aplicação do MMRI, segundo escala de Lickert:

\begin{tabular}{|l|c|}
\hline \multicolumn{1}{|c|}{ Nota/Conceito } & Freqüência \\
\hline 1 - Discordo totalmente & 1 \\
\hline 2 - Discordo parcialmente & 0 \\
\hline 3 - Indeciso & 3 \\
\hline 4 - Concordo parcialmente & 2 \\
\hline 5 - Concordo totalmente & 4 \\
\hline
\end{tabular}

$n=10$

CONCORDÂNCIA TOTAL $=40 \%$

INDECISOS $=30 \%$ 
11) Apresentação dos dados relativos à pertinência da pergunta de $n^{\circ} 4$ do $M M R I-$ Se o senhor(a) precisar de auxílio financeiro quem o(a) auxiliaria -, na $1^{\mathrm{a}}$ aplicação do MMRI, segundo escala de Lickert:

\begin{tabular}{|l|c|}
\hline \multicolumn{1}{|c|}{ Nota/Conceitos } & Freqüência \\
\hline 1 - Discordo totalmente & 1 \\
\hline 2 - Discordo parcialmente & 0 \\
\hline 3 - Indeciso & 0 \\
\hline 4 - Concordo parcialmente & 0 \\
\hline 5 - Concordo totalmente & 9 \\
\hline
\end{tabular}

CONCORDÂNCIA TOTAL $=90 \%$

12) Apresentação dos dados relativos ao registro da pergunta de $n^{\circ} 4$ no MMRI Se o senhor(a) precisar de auxílio financeiro quem o(a) auxiliaria -, na $1^{\mathrm{a}}$ aplicação do MMRI, segundo escala de Lickert:

\begin{tabular}{|l|c|}
\hline \multicolumn{1}{|c|}{ Nota/Conceito } & Freqüência \\
\hline 1 - Discordo totalmente & 1 \\
\hline 2 - Discordo parcialmente & 0 \\
\hline 3 - Indeciso & 0 \\
\hline 4 - Concordo parcialmente & 1 \\
\hline 5 - Concordo totalmente & 8 \\
\hline
\end{tabular}

$\mathrm{n}=10$

CONCORDÂNCIA TOTAL $=80 \%$

13) Apresentação dos dados relativos à adequação do MMRI em sua $1^{\mathrm{a}}$ aplicação, segundo escala de Lickert:

\begin{tabular}{|l|c|}
\hline \multicolumn{1}{|c|}{ Nota/Conceito } & Freqüência \\
\hline 1 - Discordo parcialmente & 0 \\
\hline 2 - Discordo parcialmente & 0 \\
\hline 3 - Indeciso & 0 \\
\hline 4 - Concordo parcialmente & 3 \\
\hline 5 - Concordo totalmente & 7 \\
\hline
\end{tabular}

$\mathrm{n}=10$

CONCORDÂNCIA TOTAL $=70 \%$ 


\subsection{Apresentação dos dados relativos às notas, sugestões e observações relativas às perguntas sobre dados de identificação, visita, companhia e auxílio para serviços domésticos na $2^{\mathrm{a}}$ aplicação do MMRI}

\begin{tabular}{|c|c|c|c|c|}
\hline $\begin{array}{l}\text { JUÍZES/ } \\
\text { PERGUNTAS }\end{array}$ & $\begin{array}{l}\text { As perguntas relativas aos } \\
\text { dados de identificação } \\
\text { contemplam idade, data de } \\
\text { nascimento, sexo, grau de } \\
\text { instrução e outros itens, de } \\
\text { modo que se possam } \\
\text { consolidar uma base de } \\
\text { dados sociofamiliar do } \\
\text { idoso(a). } \\
\text { Com relação à sua clareza, } \\
\text { dê uma nota de } 1 \text { a } 5:(1 \\
\text { total discordância; } 5 \text { total } \\
\text { concordância). } \\
\text { Com relação à pertinência } \\
\text { das perguntas, dê uma nota } \\
\text { de } 1 \text { a cinco: (1 total } \\
\text { discordância; } 5 \text { total } \\
\text { concordância) }\end{array}$ & $\begin{array}{l}\text { 1) Quals as pessoas que } \\
\text { o(a) visitam pelo menos: } \\
\text { - uma vez por semana? } \\
\text { - uma vez por mês? } \\
\text { - e uma vez por ano? } \\
\text { Com relação à clareza do } \\
\text { enunciado, dê uma nota de } \\
1 \text { a } 5: \text { ( } 1 \text { total discordância; } \\
5 \text { total concordância) } \\
\text { Com relação à forma de } \\
\text { registro da resposta no } \\
\text { Mapa Mínimo, dê uma nota } \\
\text { de } 1 \text { a } 5: \text { ( } 1 \text { total } \\
\text { discordância; } 5 \text { total } \\
\text { concordância) }\end{array}$ & $\begin{array}{l}\text { 2) A quem o senhor(a) } \\
\text { recorre ou recorreria se } \\
\text { precisar de alguém para lhe } \\
\text { fazer companhia? Com } \\
\text { quem acha que pode contar } \\
\text { pelo menos? } \\
\text { - uma vez por semana? } \\
\text { - uma vez por mês? } \\
\text { - e uma vez por ano? } \\
\text { Com relação à clareza do } \\
\text { enunciado, dê uma nota de } \\
1 \text { a } 5: \text { (1 total discordância; } \\
5 \text { total concordância) } \\
\text { Com relação à forma de } \\
\text { registro da resposta no } \\
\text { Mapa Mínimo, dê uma nota } \\
\text { de } 1 \text { a } 5: \text { (1 total } \\
\text { discordância; } 5 \text { total } \\
\text { concordância) }\end{array}$ & $\begin{array}{l}\text { 3) A quem o senhor(a) } \\
\text { recorre ou recorreria se } \\
\text { precisar de ajuda para } \\
\text { cuidar das coisas da casa, } \\
\text { como, por exemplo, } \\
\text { arrumar, limpar, cozinhar } \\
\text { ou fazer compras? Com } \\
\text { quem acha que pode } \\
\text { contar, pelo menos: } \\
\text { - uma vez por semana? } \\
\text { - uma vez por mês? } \\
\text { - e uma vez por ano? } \\
\text { Com relação à clareza do } \\
\text { enunciado, dê uma nota de } \\
1 \text { a } 5: \text { ( } 1 \text { total discordância; } \\
5 \text { total concordância) } \\
\text { Com relação à forma de } \\
\text { registro da resposta no } \\
\text { Mapa Mínimo, dê uma nota } \\
\text { de } 1 \text { a } 5: \text { (1 total } \\
\text { discordância; } 5 \text { total } \\
\text { concordâncla) }\end{array}$ \\
\hline $\begin{array}{l}\text { RUBI } \\
\text { Nota } \\
\text { Sugestões } \\
\text { Observações }\end{array}$ & $\begin{array}{l}\text { Com relação à clareza das } \\
\text { perguntas } \\
\text { Nota: } 5 \\
\text { Sugestões: não há. } \\
\text { Observações: Não há. } \\
\text { Quanto à pertinêncla das } \\
\text { perguntas } \\
\text { Nota: } 5 \\
\text { Sugestões: não há. } \\
\text { Observações: não há. }\end{array}$ & $\begin{array}{l}\text { Com relação à clareza do } \\
\text { enunciado } \\
\text { Nota: } 5 \\
\text { Sugestões: Definir com } \\
\text { clareza o concelto de } \\
\text { proximidade de } \\
\text { relacionamento. } \\
\text { Classiflcar as sugestões e } \\
\text { estabelecer critérios para } \\
\text { aceitação ou rejeição das } \\
\text { sugestões. } \\
\text { Observações: não há. } \\
\text { Quanto à forma de registro } \\
\text { no MMRI } \\
\text { Nota: } 5 \\
\text { Sugestões: não há. } \\
\text { Observações: não há. }\end{array}$ & $\begin{array}{l}\text { Com relação à clareza do } \\
\text { enunciado } \\
\text { Nota: } 5 \\
\text { Sugestões: não há. } \\
\text { Observações: não há. } \\
\text { Quanto à forma de registro } \\
\text { no MMRI } \\
\text { Nota: } 5 \\
\text { Sugestões: não há. } \\
\text { Observações: não há. }\end{array}$ & $\begin{array}{l}\text { Com relação à clareza do } \\
\text { enunciado } \\
\text { Nota: } 5 \\
\text { Sugestões: não há. } \\
\text { Observações: não há. } \\
\text { Quanto à forma de registro } \\
\text { no MMRI } \\
\text { Nota: } 5 \\
\text { Sugestões: não há. } \\
\text { Observações: não há. }\end{array}$ \\
\hline
\end{tabular}

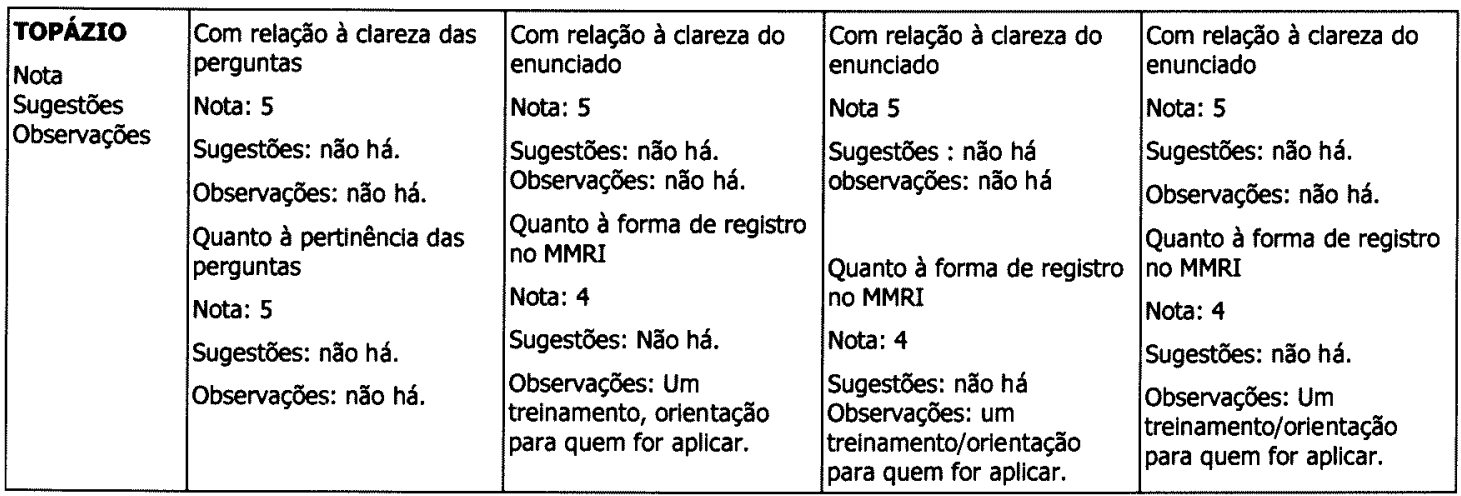




\begin{tabular}{|c|c|c|c|c|}
\hline $\begin{array}{l}\text { ÁGUA- } \\
\text { MARINHA }\end{array}$ & $\begin{array}{l}\text { Com relação à clareza da } \\
\text { pergunta }\end{array}$ & $\begin{array}{l}\text { Com relação à clareza do } \\
\text { enunciado }\end{array}$ & $\begin{array}{l}\text { Com relação à clareza do } \\
\text { enunciado }\end{array}$ & $\begin{array}{l}\text { Com relação à clareza do } \\
\text { enunciado }\end{array}$ \\
\hline $\begin{array}{l}\text { Nota } \\
\text { Sugestőes } \\
\text { Observaçōes }\end{array}$ & $\begin{array}{l}\text { Nota: 5: } \\
\text { Sugestões: não há. } \\
\text { Observações: não há. } \\
\text { Quanto à pertinência das } \\
\text { perguntas } \\
\text { Nota: } 5 \\
\text { Sugestões: não há. } \\
\text { Observações: não há. }\end{array}$ & $\begin{array}{l}\text { Nota: } 5 \\
\text { Sugestões: Registro nas } \\
\text { observaçōes sobre } \\
\text { particularidades desta } \\
\text { relação. } \\
\text { Observaçães: Talvez fosse } \\
\text { interessante nesta pergunta } \\
\text { estabelecer: } \\
\text { freqüentemente (pelo } \\
\text { menos 1x/semana); não } \\
\text { freqüentemente (1x/mês) e } \\
\text { raramente (1x/ano). } \\
\text { Quanto à forma de registro } \\
\text { no MMRI } \\
\text { Nota: } 5 \\
\text { Sugestões e observações: } \\
\text { não há. }\end{array}$ & $\begin{array}{l}\text { Nota: } 5 \\
\text { Sugestões: não há. } \\
\text { Observações: não há. } \\
\text { Quanto à forma de registro } \\
\text { no MMRI } \\
\text { Nota: } 5 \\
\text { Sugestões: não há. } \\
\text { Observações: não há. }\end{array}$ & $\begin{array}{l}\text { Nota: } 5 \\
\text { Sugestões: não há. } \\
\text { Observaç̃̃es: não há. } \\
\text { Quanto à forma de registro } \\
\text { no MMRI } \\
\text { Nota: } 5 \\
\text { Sugestões: não há. } \\
\text { Observações: não há. }\end{array}$ \\
\hline
\end{tabular}

\begin{tabular}{|c|c|c|c|c|}
\hline $\begin{array}{l}\text { ESMERALDA } \\
\text { Nota } \\
\text { Sugestões } \\
\text { Observações }\end{array}$ & 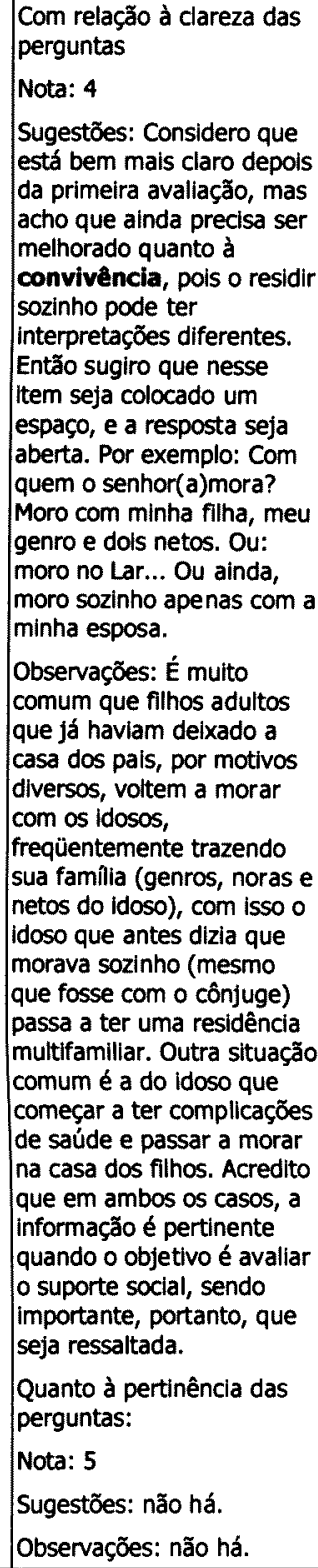 & $\begin{array}{l}\text { Com relação à clareza do } \\
\text { enunciado } \\
\text { Nota : } 4 \\
\text { Sugestões: Considero } \\
\text { importante o registro das } \\
\text { atividades socioculturais e } \\
\text { de lazer exercidas na } \\
\text { comunidade, fora do } \\
\text { domicilio, que normalmente } \\
\text { são muito significativas } \\
\text { como suporte social. Talvez } \\
\text { perguntar se o idoso } \\
\text { freqüenta algum centro de } \\
\text { convivência e com que } \\
\text { periodicidade e de quais } \\
\text { attividades comunitárias ele } \\
\text { participa. } \\
\text { Observações: Acredito que } \\
\text { se for perguntado apenas } \\
\text { sobre quem o visita, é } \\
\text { possivel que as respostas } \\
\text { sejam mais limitadas, pois } \\
\text { multas vezes o idoso recebe } \\
\text { ajuda, suporte, sem receber } \\
\text { uma visita. Por exemplo } \\
\text { quando freqüenta um } \\
\text { centro de convivência ou } \\
\text { outro serviço semelhante. } \\
\text { Quanto à forma de registro } \\
\text { no MMRI } \\
\text { Nota: } 5 \\
\text { Sugestões: não há. } \\
\text { Observações: não há. } \\
\end{array}$ & $\begin{array}{l}\text { Com relação à clareza do } \\
\text { enunciado } \\
\text { Nota: } 4 \\
\text { Sugestões: Com quem o } \\
\text { senhor(a) conta ou contaria } \\
\text { no caso de desejar ou } \\
\text { precisar de companhia? } \\
\text { Quanto à forma de registro } \\
\text { no MMRI } \\
\text { Nota: } 5 \\
\text { Sugestões: não há. } \\
\text { Observações: não há. } \\
\end{array}$ & $\begin{array}{l}\text { Com relação à clareza do } \\
\text { enunciado } \\
\text { Nota: } 4 \\
\text { Sugestões: Quando o } \\
\text { senhor(a) precisar de ajuda } \\
\text { para culdar das coisas da } \\
\text { casa, como arrumar, limpar, } \\
\text { cozinhar ou fazer compras, } \\
\text { com quem acha que pode } \\
\text { contar, pelo menos: } \\
\text { - uma vez por semana? } \\
\text { - uma vez por mês? } \\
\text { - e uma vez por ano? } \\
\text { Observaçб̃es: Acho que } \\
\text { pode ficar um pouco mais } \\
\text { claro. } \\
\text { Quanto à forma de registro } \\
\text { no MMRI } \\
\text { Nota: } 5 \\
\text { Sugestões: não há. } \\
\text { Observações: não há. }\end{array}$ \\
\hline
\end{tabular}




\begin{tabular}{|c|c|c|c|c|}
\hline $\begin{array}{l}\text { JADE } \\
\text { Nota } \\
\text { Sugestões } \\
\text { Observações }\end{array}$ & $\begin{array}{l}\text { Com relação à dareza das } \\
\text { perguntas } \\
\text { Nota: } 5 \\
\text { Sugestões: não há. } \\
\text { Observações: não há. } \\
\text { Quanto à pertinência das } \\
\text { perguntas } \\
\text { Nota: } 5 \\
\text { Sugestões: não há. } \\
\text { Observaçōes: não há. }\end{array}$ & $\begin{array}{l}\text { Com relação à dareza do } \\
\text { enunciado } \\
\text { Nota: } 5 \\
\text { Sugestões: não há. } \\
\text { Observações: Não há. } \\
\text { Quanto à forma de registro } \\
\text { da resposta no Mapa } \\
\text { Mínimo } \\
\text { Nota: } 5 \\
\text { Sugestŏes: Não há. } \\
\text { Observações: Não há. }\end{array}$ & $\begin{array}{l}\text { Com relação à clareza do } \\
\text { enunciado } \\
\text { Nota: } 4 \\
\text { Sugestões: Acho que o } \\
\text { enunciado deveria ser: } \\
\text { Com quem o senhor acha } \\
\text { que pode contar para lhe } \\
\text { fazer companhia, } \\
\text { - pelo menos } 1 \text { vez (...) } \\
\text { Observaçöes: Duas } \\
\text { questōes numa mesma } \\
\text { pergunta podem confundir } \\
\text { o ldoso. } \\
\text { Quanto à forma de registro } \\
\text { da resposta no Mapa } \\
\text { Mínimo } \\
\text { Nota:5 } \\
\text { Sugestões: não há. } \\
\text { Observaçס̃es: não há. }\end{array}$ & $\begin{array}{l}\text { Com relação à clareza do } \\
\text { enunciado } \\
\text { Nota: } 4 \\
\text { Sugestões: Ainda acho o } \\
\text { enunciado muito grande. } \\
\text { Quem sabe reduzir para: } \\
\text { Com quem o senhor pode } \\
\text { contar para os serviços da } \\
\text { casa (limpar... etc.), pelo } \\
\text { menos } 1 \text { vez (...) } \\
\text { Observaçס̃es: não há. } \\
\text { Quanto à forma de registro } \\
\text { da resposta no Mapa } \\
\text { Mínimo } \\
\text { Nota: } 5 \\
\text { Sugestões: não há. } \\
\text { Observações: não há. }\end{array}$ \\
\hline
\end{tabular}

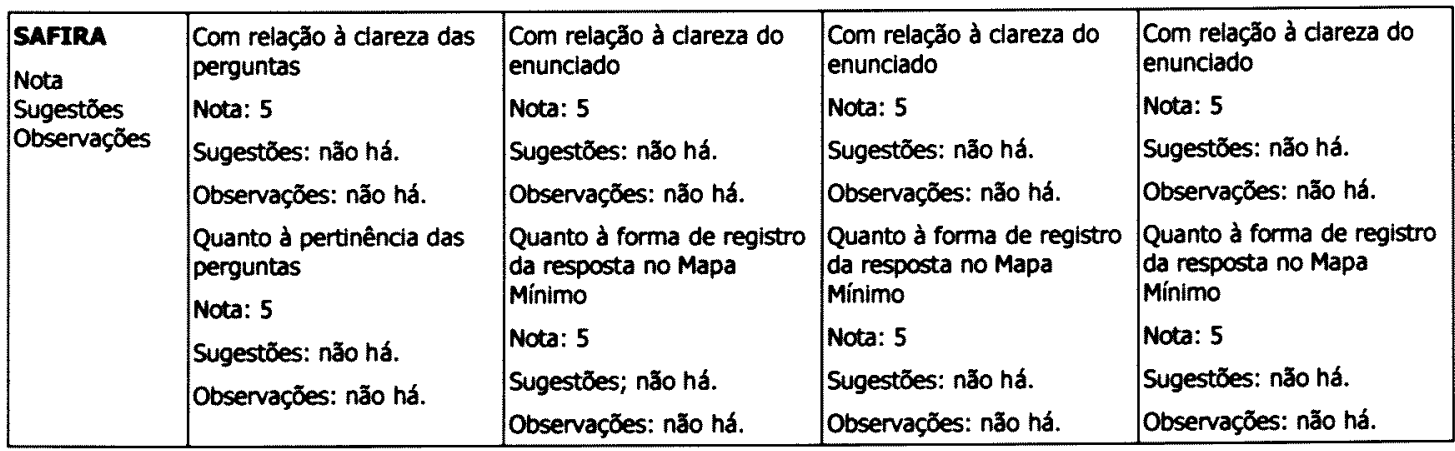

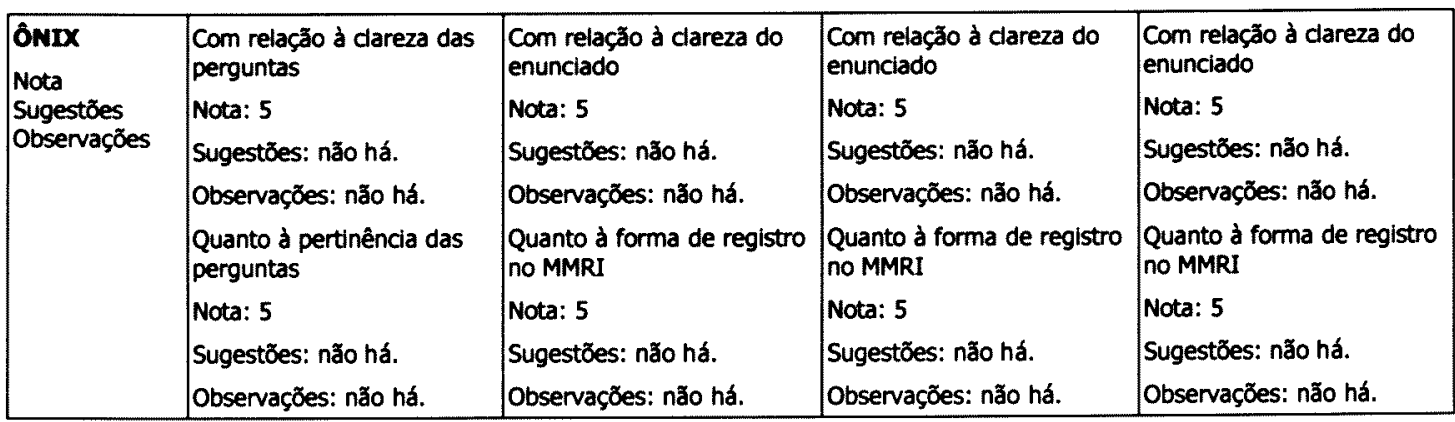

\begin{tabular}{|c|c|c|c|c|}
\hline $\begin{array}{l}\text { TURMALIMA } \\
\text { Nota } \\
\text { Sugestőes } \\
\text { Observaçס̄es }\end{array}$ & $\begin{array}{l}\text { Com relação à dlareza das } \\
\text { perguntas } \\
\text { Nota: } 4 \\
\text { Sugestão: No item 4, } \\
\text { acrescentar "sem } \\
\text { escolaridade", ou } \\
\text { "alfabetzzado", "não- } \\
\text { alfabetizado" } \\
\text { Observaçōes: Isso porque } \\
\text { este fato pode influenciar } \\
\text { na obtençăo de direitos } \\
\text { básicos: ler jornais, } \\
\text { aposentadoria etc. } \\
\text { Quanto à pertinência das } \\
\text { perguntas } \\
\text { Nota: } 5 \\
\text { Sugestões: não há. } \\
\text { Observações: não há. }\end{array}$ & $\begin{array}{l}\text { Com relação à clareza do } \\
\text { enunciado } \\
\text { Nota: } 5 \\
\text { Sugestão: não há. } \\
\text { Observações: não há. } \\
\text { Quanto à forma de registro } \\
\text { no MMRI } \\
\text { Nota: } 5 \\
\text { Sugestães: não há. } \\
\text { Observaçőes: não há. }\end{array}$ & $\begin{array}{l}\text { Com relação à clareza do } \\
\text { enunclado } \\
\text { Nota: } 5 \\
\text { Sugestão: não há. } \\
\text { Observações: não há. } \\
\text { Quanto à forma de registro } \\
\text { no MMRI } \\
\text { Nota: } 5 \\
\text { Sugestão: não há. } \\
\text { Observações: não há. }\end{array}$ & $\begin{array}{l}\text { Com relação à clareza do } \\
\text { enunciado } \\
\text { Nota: } 5 \\
\text { Sugestão: não há. } \\
\text { Observaçz̋es: não há. } \\
\text { Quanto à forma de registro } \\
\text { no MMRI } \\
\text { Nota: } 5 \\
\text { Sugestão: não há. } \\
\text { Observaçōes: não há. }\end{array}$ \\
\hline
\end{tabular}




\begin{tabular}{|c|c|c|c|c|}
\hline \multirow{8}{*}{$\begin{array}{l}\text { ÁGATA } \\
\text { Nota } \\
\text { Sugestz̃es } \\
\text { Observações }\end{array}$} & $\begin{array}{l}\text { Com relação à clareza das } \\
\text { perguntas }\end{array}$ & $\begin{array}{l}\text { Com relação à clareza do } \\
\text { enunciado }\end{array}$ & $\begin{array}{l}\text { Com relação à clareza do } \\
\text { enunciado }\end{array}$ & $\begin{array}{l}\text { Com relação à clareza do } \\
\text { enunciado }\end{array}$ \\
\hline & Nota: 5 & Nota: 5 & Nota: 5 & Nota: 5 \\
\hline & Sugestões: não há. & Sugestões: não há. & Sugestões: não há. & Sugestões: não há. \\
\hline & Observações: não há. & Observações: não há. & Observações: não há. & Observações: não há. \\
\hline & $\begin{array}{l}\text { Quanto à pertinência das } \\
\text { perguntas }\end{array}$ & $\begin{array}{l}\text { Quanto à forma de registro } \\
\text { no MMRI }\end{array}$ & $\begin{array}{l}\text { Quanto à forma de registro } \\
\text { no MMRI }\end{array}$ & $\begin{array}{l}\text { Quanto d forma de registro } \\
\text { no MMRI }\end{array}$ \\
\hline & Nota: 5 & Nota: 5 & Nota: 5 & Nota: 5 \\
\hline & Sugestões: não há. & Sugestões: não há. & Sugestões: não há. & Sugestões: não há. \\
\hline & Observações: não há. & Observações: não há. & Observações: não há. & Observações: não há. \\
\hline \multirow{8}{*}{$\begin{array}{l}\text { OPALA } \\
\text { Nota } \\
\text { Sugestões } \\
\text { Observações }\end{array}$} & $\begin{array}{l}\text { Com relação à clareza das } \\
\text { perguntas }\end{array}$ & $\begin{array}{l}\text { Com relação à clareza do } \\
\text { enunciado }\end{array}$ & $\begin{array}{l}\text { Com relação à clareza do } \\
\text { enunciado }\end{array}$ & $\begin{array}{l}\text { Com relação à clareza do } \\
\text { enunciado }\end{array}$ \\
\hline & Nota: 5 & Nota: 5 & Nota: 5 & Nota: 5 \\
\hline & Sugestões: não há. & Sugestőes: não há. & Sugestões: não há. & Sugestões: não há. \\
\hline & Observações: não há. & Observações: não há. & Observações: não há. & Observações: não há. \\
\hline & $\begin{array}{l}\text { Quanto à pertinência das } \\
\text { perguntas }\end{array}$ & $\begin{array}{l}\text { Quanto à forma de registro } \\
\text { no MMRI }\end{array}$ & $\begin{array}{l}\text { Quanto à forma de registro } \\
\text { no MMRI }\end{array}$ & $\begin{array}{l}\text { Quanto à forma de registro } \\
\text { no MMRI }\end{array}$ \\
\hline & Nota: 5 & Nota: 5 & Nota: 5 & Nota: 5 \\
\hline & Sugestões: não há. & Sugestões: não há. & Sugestões: não há. & Sugestð̃es: não há. \\
\hline & Observações: não há. & Observações: não há. & Observações: não há. & Observações: não há. \\
\hline
\end{tabular}

\subsection{Apresentação dos dados relativos às notas, sugestões e observações relativas às perguntas sobre auxílio para cuidados pessoais, auxílio financeiro e quanto a apresentação gráfica do instrumento na $2^{\mathrm{a}}$ aplicação do MMRI}

\begin{tabular}{|c|c|c|c|}
\hline \multirow[t]{9}{*}{$\begin{array}{l}\text { JUÍZES/ } \\
\text { PERGUNTAS }\end{array}$} & \multirow{9}{*}{$\begin{array}{l}\text { 4) A quem o senhor(a) recorre ou } \\
\text { recorreria se precisar de ajuda, por } \\
\text { exemplo, para trocar de roupa, tomar } \\
\text { banho, comer, se levantar, se deitar? } \\
\text { Com que acha que pode contar, pelo } \\
\text { menos: } \\
\text { - uma vez por semana? } \\
\text { - uma vez por mês? } \\
\text { - e uma vez por ano? } \\
\text { Com relação à clareza do enunciado, } \\
\text { dê uma nota de } 1 \text { a } 5: \text { ( } 1 \text { total } \\
\text { dlscordâncla; } 5 \text { total concordância) } \\
\text { Oom relação à forma de registro da } \\
\text { resposta no Mapa Minimo, dê uma } \\
\text { nota de } 1 \text { a } 5: \text { ( } 1 \text { total discordância; } \\
5 \text { total concordância) }\end{array}$} & \multirow{9}{*}{$\begin{array}{l}\text { 5) A quem o senhor(a) recorre ou } \\
\text { recorreria se precisar de auxílo para } \\
\text { pagar uma conta, comprar um } \\
\text { remédio ou para outras despesas } \\
\text { como, por exemplo, com } \\
\text { alimentaçăo, ou aluguel da sua casa? } \\
\text { Com quem acha que pode contar, } \\
\text { pelo menos: } \\
\text { - uma vez por semana? } \\
\text { - uma vez por mês? } \\
\text { - e uma vez por ano? } \\
\text { Com relação à clareza do enunciado, } \\
\text { dê uma nota de } 1 \text { a } 5: \text { ( } 1 \text { total } \\
\text { discordância; } 5 \text { total concordância) } \\
\text { Com relação à forma de registro da } \\
\text { resposta no Mapa Mínimo, dê uma } \\
\text { nota de } 1 \text { a } 5: \text { (1 total discordância; } \\
5 \text { total concordância) }\end{array}$} & $\begin{array}{l}\text { 6) Quanto à apresentação gráfica do } \\
\text { instrumento: }\end{array}$ \\
\hline & & & \multirow{8}{*}{$\begin{array}{l}\text { Com relação d̀ adequação do MMRI } \\
\text { dê uma nota de } 1 \text { a } 5: \text { ( } 1 \text { total } \\
\text { discordâncla; } 5 \text { total concordância) }\end{array}$} \\
\hline & & & \\
\hline & & & \\
\hline & & & \\
\hline & & & \\
\hline & & & \\
\hline & & & \\
\hline & & & \\
\hline \multirow{8}{*}{$\begin{array}{l}\text { RUBI } \\
\text { Nota } \\
\text { sugestões } \\
\text { Observações }\end{array}$} & Com relação à clareza do enunciado & \multirow{8}{*}{$\begin{array}{l}\text { Com relação à clareza do enunciado } \\
\text { Nota: } 5 \\
\text { Sugestões: não há. } \\
\text { Observações: não há. } \\
\text { Quanto à forma de registro no MMRI } \\
\text { Nota: } 5 \\
\text { Sugestões: não há. } \\
\text { Observações: não há. }\end{array}$} & \multirow{8}{*}{$\begin{array}{l}\text { Com relação à adequação do MMRI } \\
\text { Nota: } 5 \\
\text { Sugestões: não há. } \\
\text { Observações: não há. }\end{array}$} \\
\hline & Nota: 5 & & \\
\hline & Sugestões: não há. & & \\
\hline & Observações: não há. & & \\
\hline & Quanto à forma de registro no MMRI & & \\
\hline & Nota: 5 & & \\
\hline & Sugestões: não há. & & \\
\hline & Observaç̃es: não há. & & \\
\hline
\end{tabular}




\begin{tabular}{|c|c|c|c|}
\hline $\begin{array}{l}\text { TOPÁzio } \\
\text { Nota } \\
\text { sugestães } \\
\text { Observaçães }\end{array}$ & $\begin{array}{l}\text { Com relação à dareza do enunciado } \\
\text { Nota: } 5 \\
\text { Sugestőes: não há. } \\
\text { Observaçő́es: não há. } \\
\text { Quanto à forma de registro no MMRI } \\
\text { Nota: } 4 \\
\text { Sugestões: não há. } \\
\text { Observaçđ̃es: Treinamento/orientação } \\
\text { para quem for aplicar? }\end{array}$ & $\begin{array}{l}\text { Com relação à dareza do enunciado } \\
\text { Nota: } 5 \\
\text { Sugestões: não há. } \\
\text { Observaçőes: năo há. } \\
\text { Quanto à forma de registro no MMRI } \\
\text { Nota: } 4 \\
\text { Sugestões: não há. } \\
\text { Observaçð̋es: Treinamento/orientação } \\
\text { para quem for aplicar? }\end{array}$ & $\begin{array}{l}\text { Com relação à adequação do MMRI } \\
\text { Nota: } 4 \\
\text { Observaçōes: Um treinamento/ } \\
\text { orientação para quem for aplicar o } \\
\text { instrumento. }\end{array}$ \\
\hline $\begin{array}{l}\text { AGUA- } \\
\text { MaRINHA } \\
\text { Nota } \\
\text { sugestões } \\
\text { Observações }\end{array}$ & $\begin{array}{l}\text { Com relação à dareza do enunciado } \\
\text { Nota: } 5 \\
\text { Sugestões e observações: não há. } \\
\text { Quanto à forma de registro no MMRI } \\
\text { Nota:5 } \\
\text { Sugestões e observações: não há. }\end{array}$ & $\begin{array}{l}\text { Com relação à dareza do enunciado } \\
\text { Nota: } 5 \\
\text { Sugestões e observações: não há. } \\
\text { Quanto à forma de registro no MMRI } \\
\text { Nota: } 5 \\
\text { Sugestð̃es e observações: não há. }\end{array}$ & $\begin{array}{l}\text { Com relação à adequação do MMRI } \\
\text { Nota: } 5 \\
\text { Sugestões: Utillizar sempre e com } \\
\text { detalhes o setor observações, para o } \\
\text { MMRI atingir plenamente o seu } \\
\text { objetivo. }\end{array}$ \\
\hline
\end{tabular}

\begin{tabular}{|c|c|c|c|}
\hline $\begin{array}{l}\text { ESMERALDA } \\
\text { Nota } \\
\text { sugestððes } \\
\text { Observaçöes }\end{array}$ & $\begin{array}{l}\text { Com relação à dareza do enunciado } \\
\text { Nota: } 5 \\
\text { Sugestőes: não há. } \\
\text { Observaçōes: Por ser um assunto } \\
\text { delicado, acho que a pergunta tem } \\
\text { que ser o mais suave possivel. } \\
\text { Quanto à forma de registro no MMRI } \\
\text { Nota: } 5 \\
\text { Sugestð̃es: não há. } \\
\text { Observaçס̋es: não há. }\end{array}$ & 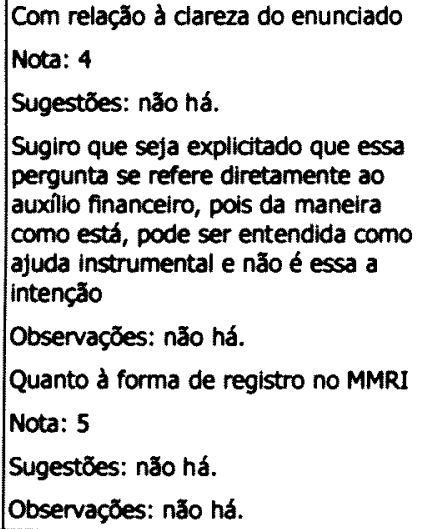 & $\begin{array}{l}\text { Com relaçăo à adequação do MMRI } \\
\text { Nota: } 5 \\
\text { Sugestôes: não há. } \\
\text { Observaçōes: Considero o MMRI um } \\
\text { instrumento de fácil visualizaç̧o, mas } \\
\text { o treinamento dos entrevistadores } \\
\text { tem que ser muito preciso, pois ele } \\
\text { exige muita atenção e traquejo. }\end{array}$ \\
\hline
\end{tabular}

\begin{tabular}{|c|c|c|c|}
\hline $\begin{array}{l}\text { JADE } \\
\text { Nota } \\
\text { sugestöes } \\
\text { Observaçōes }\end{array}$ & $\begin{array}{l}\text { Com relação à dareza do enunciado } \\
\text { Nota: } 4 \\
\text { Sugestões: Com quem o senhor pode } \\
\text { contar para os cuidados pessoa is } \\
\text { (banho...etc.), } \\
\text { pelo menos } 1 \text { vez... etc. } \\
\text { Observações: não há. } \\
\text { Quanto à forma de registro no MMRI } \\
\text { Nota: } 5 \\
\text { Sugestð̃es: não há. } \\
\text { Observações: não há. }\end{array}$ & 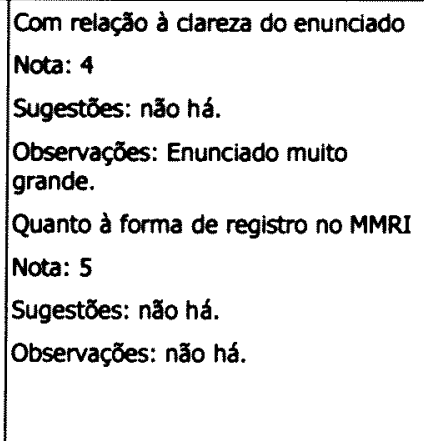 & $\begin{array}{l}\text { Com relação à adequação do MMRI } \\
\text { Nota: } 5 \\
\text { Sugestões: não há. } \\
\text { Observaçōes: não há. }\end{array}$ \\
\hline
\end{tabular}

\begin{tabular}{|c|c|c|c|}
\hline $\begin{array}{l}\text { SAFIRA } \\
\text { Nota } \\
\text { sugestães } \\
\text { Observações }\end{array}$ & $\begin{array}{l}\text { Quanto à clareza do enunciado } \\
\text { Nota: } 5 \\
\text { Sugestões: não há. } \\
\text { Observaçōes: não há. } \\
\text { Quanto à forma de registro no MMRI } \\
\text { Nota: } 5 \\
\text { Sugestões: não há. } \\
\text { Observação: não há. }\end{array}$ & $\begin{array}{l}\text { Com relação à dareza do enunciado } \\
\text { Nota: } 5 \\
\text { Sugestőes: não há. } \\
\text { Observaçâes: não há. } \\
\text { Quanto à forma de registro no MMRI } \\
\text { Nota: } 5 \\
\text { Sugestżes: não há. } \\
\text { Observações: não há. }\end{array}$ & $\begin{array}{l}\text { Com relação à adequação do MMRI } \\
\text { Nota: } 5 \\
\text { Sugestões: não há. } \\
\text { Observações: não há. }\end{array}$ \\
\hline
\end{tabular}




\begin{tabular}{|l|l|l|l|}
\hline ÓNIX & Com relação à clareza do enunciado & Com relação à clareza do enunciado & Com relação à adequação do MMRI \\
Nota & Nota: 5 & Nota: 5 & Nota: 5 \\
sugestões & Sugestões: não há. & Sugestões: não há. & Sugestões: não há. \\
Observações & Observações: não há. & Observações: não há. & \\
& Quanto à forma de registro no MMRI & Quanto à forma de registro no MMRI não há. \\
& Nota: 5 & Nota: 5 & \\
& Sugestões: não há. & Sugestões: não há. & \\
& Observações: não há. & Observações: não há. & \\
\hline
\end{tabular}

\begin{tabular}{|c|c|c|c|}
\hline $\begin{array}{l}\text { TURMALINA } \\
\text { Nota } \\
\text { sugestões } \\
\text { Observações }\end{array}$ & $\begin{array}{l}\text { Com relação à clareza do enunciado } \\
\text { Nota: } 5 \\
\text { Sugestão: não há } \\
\text { Observaçães: não há } \\
\text { Quanto à forma de registro no MMRI } \\
\text { Nota: } 5 \\
\text { Sugestão: não há. } \\
\text { Observações: não há. }\end{array}$ & $\begin{array}{l}\text { Com relação à clareza do enunciado } \\
\text { Nota: } 3 \\
\text { Sugestőes: A questão deve } \\
\text { differenclar auxilio no sentido } \\
\text { financeiro e não de serviços. } \\
\text { Observações: não há. } \\
\text { Quanto à forma de registro no MMRI } \\
\text { Nota: } 5 \\
\text { Sugestões: não há. } \\
\text { Observaçōes: não há. }\end{array}$ & $\begin{array}{l}\text { Com relação à adequação do MMRI } \\
\text { Nota: } 5 \\
\text { Sugestões: não há. } \\
\text { Observações: não há. }\end{array}$ \\
\hline
\end{tabular}

\begin{tabular}{|c|c|c|c|}
\hline $\begin{array}{l}\text { ÁGATA } \\
\text { Nota } \\
\text { sugestões } \\
\text { Observaçס̃es }\end{array}$ & $\begin{array}{l}\text { Com relação à clareza do enunciado } \\
\text { Nota: } 5 \\
\text { Quanto à forma de registro no MMRI } \\
\text { Nota: } 5 \\
\text { Sugestões: não há. } \\
\text { Observações: não há. }\end{array}$ & $\begin{array}{l}\text { Com relação à clareza do enunciado } \\
\text { Nota: } 4 \\
\text { Sugestð̃es: não há. } \\
\text { Observaçð̃es: não há. } \\
\text { Quanto à forma de registro no MMRI } \\
\text { Nota: } 5 \\
\text { Sugestões: não há. } \\
\text { Observaçð̃es: não há. }\end{array}$ & $\begin{array}{l}\text { Com relação à adequação do MMRI } \\
\text { Nota: } 5 \\
\text { Sugestões: não há. } \\
\text { Observações: não há. }\end{array}$ \\
\hline
\end{tabular}

\begin{tabular}{|l|l|l|l|}
\hline OPALA & Com relação à clareza do enunclado & Com relação à clareza do enunciado & Com relação à adequação do MMRI \\
Nota & Nota: 5 & Nota: 5 & Nota: 5 \\
sugestões & Sugestões: não há. & Sugestões: não há. & Sugestões: não há. \\
Observações & Observaç̋̃es: não há. & Observaçães: não há. \\
& Quanto à forma de registro no MMRI & Quanto à forma de registro no MMRI & \\
& Nota: 5 & Nota: 5 & \\
& Sugestões: não há. & Sugestões: não há. \\
& Observaçães: não há. & Observações: não há. & \\
\hline
\end{tabular}

\subsection{Apresentação dos dados relativos à $2^{\mathrm{a}}$ aplicação do instrumento, segundo a escala de Lickert}

Para a elaboração dessa análise as notas dadas pelos juízes para cada questão do MMRI corresponderam a um peso assim definido:

1 - discordo totalmente

2 - discordo parcialmente

3 - indeciso
4 - concordo parcialmente

5 - concordo totalmente 
1) Apresentação dos dados relativos à clareza da pergunta sobre dados de identificação, na $2^{\mathrm{a}}$ aplicação do MMRI, segundo a escala de Lickert:

\begin{tabular}{|l|c|}
\hline \multicolumn{1}{|c|}{ Nota/Conceito } & Freqüência \\
\hline 1 - Discordo totalmente & 0 \\
\hline 2 - Discordo parcialmente & 0 \\
\hline 3 - Indeciso & 0 \\
\hline 4 - Concordo parcialmente & 2 \\
\hline 5 - Concordo totalmente & 8 \\
\hline
\end{tabular}

$\mathrm{n}=10$

CONCORDÂNCIA TOTAL $=80 \%$

2) Apresentação dos dados relativos à pertinência da pergunta sobre dados de identificação, na $2^{\mathrm{a}}$ aplicação do MMRI, segundo escala de Lickert:

\begin{tabular}{|l|c|}
\hline \multicolumn{1}{|c|}{ Nota/Conceito } & Freqüência \\
\hline 1 - Discordo totalmente & 0 \\
\hline 2 - Discordo parcialmente & 0 \\
\hline 3 - Indeciso & 0 \\
\hline 4 - Concordo parcialmente & 0 \\
\hline 5 - Concordo totalmente & 10 \\
\hline
\end{tabular}

$n=10$

CONCORDÂNCIA TOLTAL $=100 \%$

3) Apresentação dos dados relativos à clareza da pergunta de $n^{\circ} 1$ - Quais as pessoas que o (a) visitam pelo menos: Uma vez por semana? Uma vez por mês? Uma vez por ano? Segundo escala de Lickert, na $2^{a}$ aplicação do MMRI.

\begin{tabular}{|l|c|}
\hline \multicolumn{1}{|c|}{ Nota/Conceito } & Freqüência \\
\hline 1 - Discordo totalmente & 0 \\
\hline 2 - Discordo parcialmente & 0 \\
\hline 3 - Indeciso & 0 \\
\hline 4 - Concordo parcialmente & 1 \\
\hline 5 - Concordo totalmente & 9 \\
\hline
\end{tabular}

$n=10$

CONCORDÂNCIA TOTAL $=90 \%$ 
4) Apresentação dos dados relativos ao registro da pergunta de $n^{\circ} 1$ - Quais as pessoas que o(a) visitam pelo menos: Uma vez por semana? Uma vez por mês? Uma vez por ano? Segundo escala de Lickert, na $2^{\text {a }}$ aplicação do MMRI.

\begin{tabular}{|l|c|}
\hline \multicolumn{1}{|c|}{ Nota/Conceito } & Freqüência \\
\hline 1 - Discordo totalmente & 0 \\
\hline 2- Discordo parcialmente & 0 \\
\hline 3 - Indeciso & 0 \\
\hline 4 - Concordo parcialmente & 1 \\
\hline 5 - Concordo totalmente & 9 \\
\hline
\end{tabular}

$n=10$

CONCORDÂNCIA TOTAL $=90 \%$

5) Apresentação dos dados relativos à clareza da pergunta de $n^{\circ} 2-A$ quem o senhor(a) recorre ou recorreria se precisar de alguém para lhe fazer companhia? Com quem acha que pode contar pelo menos: Uma vez por semana? Uma vez por mês? Uma vez por ano? Segundo escala de Lickert, na $2^{a}$ aplicação do MMRI.

\begin{tabular}{|l|c|}
\hline \multicolumn{1}{|c|}{ Nota/Conceito } & Freqüência \\
\hline 1 - Discordo totalmente & 0 \\
\hline 2 - Discordo parcialmente & 0 \\
\hline 3 - Indeciso & 0 \\
\hline 4 - Concordo parcialmente & 2 \\
\hline 5 - Concordo totalmente & 8 \\
\hline
\end{tabular}

$\mathrm{n}=10$

CONCORDÂNCIA TOTAL $=80 \%$ 
6) Apresentação dos dados relativos ao registro da pergunta de $n^{\circ} 2-$ A quem o senhor(a) recorre ou recorreria se precisar de alguém para lhe fazer companhia? Com quem acha que pode contar pelo menos: Uma vez por semana? Uma vez por mês? Uma vez por ano? Segundo escala de Lickert, na $2^{\mathrm{a}}$ aplicação do MMRI.

\begin{tabular}{|l|c|}
\hline \multicolumn{1}{|c|}{ Notas/Conceito } & Freqüência \\
\hline 1 - Discordo totalmente & 0 \\
\hline 2 - Discordo parcialmente & 0 \\
\hline 3 - Indeciso & 0 \\
\hline 4 - Concordo parcialmente & 1 \\
\hline 5 - Concordo totaimente & 9 \\
\hline$n=10$
\end{tabular}

CONCORDÂNCIA TOTAL $=90 \%$

7) Apresentação dos dados relativos à clareza da pergunta de $\mathrm{n}^{\circ} \mathbf{3}-\mathrm{A}$ quem o senhor(a) recorre ou recorreria se precisar de ajuda para cuidar das coisas da casa, como, por exemplo, arrumar, limpar, cozinhar ou fazer compras? Com quem acha que pode contar pelo menos: Uma vez por semana? Uma vez por mês? Uma vez por ano? Segundo escala de Lickert, na $2^{\mathrm{a}}$ aplicação do MMRI.

\begin{tabular}{|l|c|}
\hline \multicolumn{1}{|c|}{ Nota/Conceito } & Freqüû́ncia \\
\hline 1- Discordo totalmente & 0 \\
\hline 2 - Discordo parcialmente & 0 \\
\hline 3- Indeciso & 0 \\
\hline 4- Concordo parcialmente & 2 \\
\hline 5 - Concordo totalmente & 8 \\
\hline
\end{tabular}

$n=10$

CONCORDÂNCLA TOTAL $=80 \%$ 
8) Apresentação dos dados relativos ao registro da pergunta de $n^{\circ} 3$ - A quem o senhor(a) recorre ou recorreria se precisar de ajuda para cuidar das coisas da casa, como, por exemplo, arrumar, limpar, cozinhar ou fazer compras? Com quem acha que pode contar pelo menos: Uma vez por semana? Uma vez por mês? Uma vez por ano? Segundo escala de Lickert, na $2^{a}$ aplicação do MMRI.

\begin{tabular}{l|c|}
\hline \multicolumn{1}{|c|}{ Nota/Conceito } & Freqüência \\
\hline 1 - Discordo totalmente & 0 \\
\hline 2 - Discordo parcialmente & 0 \\
\hline 3 - Indeciso & 0 \\
\hline 4 - Concordo parcialmente & 1 \\
\hline 5 - Concordo totalmente & 9 \\
\hline$n=10$ \\
CONCORDÂNCIA TOTAL $=90 \%$
\end{tabular}

9) Apresentação dos dados relativos à clareza da pergunta de $n^{\circ} 4-A$ quem o senhor(a) recorre ou recorreria se precisar de ajuda, por exemplo, para trocar de roupa, tomar banho, comer se levantar, se deitar? Com quem acha que pode contar pelo menos: uma vez por semana? Uma vez por mês? Uma vez por ano? Segundo escala de Lickert, na $2^{\mathrm{a}}$ aplicação do MMRI.

\begin{tabular}{|l|c|}
\hline \multicolumn{1}{|c|}{ Nota/Conceito } & Freqüência \\
\hline 1 - Discordo totalmente & 0 \\
\hline 2 - Discordo parcialmente & 0 \\
\hline 3 - Indeciso & 0 \\
\hline 4 - Concordo parcialmente & 1 \\
\hline 5 - Concordo totalmente & 9 \\
\hline
\end{tabular}

CONCORDÂNCIA TOTAL $=90 \%$ 
10) Apresentação dos dados relativos ao registro da pergunta de $n^{\circ} 4$ - a quem o senhor(a) recorre ou recorreria se precisar de ajuda, por exemplo, para trocar de roupa, tomar banho, comer se levantar, se deitar? Com quem acha que pode contar pelo menos: uma vez por semana? Uma vez por mês? Uma vez por ano? Segundo escala de Lickert, na $2^{\mathrm{a}}$ aplicação do MMRI.

\begin{tabular}{|l|c|}
\hline \multicolumn{1}{|c|}{ Nota/Conceito } & Freqüência \\
\hline 1 - Discordo totalmente & 0 \\
\hline 2 - Discordo parcialmente & 0 \\
\hline 3 - Indeciso & 0 \\
\hline 4 - Concordo parcialmente & 1 \\
\hline 5 - Concordo totalmente & 9 \\
\hline
\end{tabular}

$n=10$

\section{CONCORDÂNCIA TOTAL $=90 \%$}

11) Apresentação dos dados relativos à clareza da pergunta de $n^{\circ} 5$ - a quem o senhor(a) recorre ou recorreria se precisar de auxílio para pagar uma conta, comprar um remédio ou para outras despesas, por exemplo, com alimentação, ou aluguel da sua casa? Com quem acha que pode contar pelo menos: Uma vez por semana? Uma vez por mês? Uma vez por ano? Segundo escala de Lickert, na $2^{\mathrm{a}}$ aplicação do MMRI.

\begin{tabular}{|l|c|}
\hline \multicolumn{1}{|c|}{ Nota/Conceito } & Freqüência \\
\hline 1 - Discordo totalmente & 0 \\
\hline 2 - Discordo parcialmente & 0 \\
\hline 3 - Indeciso & 1 \\
\hline 4 - Concordo parcialmente & 3 \\
\hline 5 - Concordo totalmente & 6 \\
\hline$n=10$
\end{tabular}

CONCORDÂNCIA TOTAL $=60 \%$ 
12) Apresentação dos dados relativos ao registro da pergunta de $n^{\circ} 5$ - a quem o senhor(a) recorre ou recorreria se precisar de auxílio para pagar uma conta, comprar um remédio ou para outras despesas, por exemplo, com alimentação, ou aluguel da sua casa? Com quem acha que pode contar pelo menos: Uma vez por semana? Uma vez por mês? Uma vez por ano? Segundo escala de Lickert, na $2^{\mathrm{a}}$ aplicação do MMRI.

\begin{tabular}{|l|c|}
\hline \multicolumn{1}{|c|}{ Nota/Conceito } & Freqüência \\
\hline 1 - Discordo totalmente & 0 \\
\hline 2 - Discordo parcialmente & 0 \\
\hline 3 - Indeciso & 0 \\
\hline 4 - Concordo parcialmente & 1 \\
\hline 5 - Concordo totaimente & 9 \\
\hline$n=10$
\end{tabular}

CONCORDÂNCLA TOTAL $=90 \%$

13) Apresentação dos dados relativos à adequação do MMRI em sua $2^{a}$ aplicação, segundo escala de Lickert:

\begin{tabular}{|l|c|}
\hline \multicolumn{1}{|c|}{ Nota/Conceito } & Freqüência \\
\hline 1 - Discordo parcialmente & 0 \\
\hline 2 - Discordo parcialmente & 0 \\
\hline 3 - Indeciso & 0 \\
\hline 4 - Concordo parcialmente & 1 \\
\hline 5 - Concordo totalmente & 9 \\
\hline
\end{tabular}

$\mathrm{n}=10$

CONCORDÂNCIA TOTAL $=90 \%$ 


\subsection{Apresentação dos dados relativos às notas, sugestões e observações relativas à pergunta sobre auxílio financeiro na $3^{a}$ aplicação do MMRI}

\begin{tabular}{|l|l|}
\hline JUÍzES/ & $\begin{array}{l}\text { 5) Quem ajuda ou ajudaria o senhor(a) financeiramente, se precisar de auxílio para pagar aluguel da } \\
\text { PERGUNTAS casa, pagar uma conta, comprar comida, remédio etc., pelo menos: Uma vez por semana? Uma } \\
\text { vez por mês? e Uma vez por ano? } \\
\text { Com relação à clareza do enunciado, dê uma nota de } 1 \text { a } 5: \text { (1 total discordância; } 5 \text { total concordância) }\end{array}$ \\
\hline
\end{tabular}

\begin{tabular}{|l|l|}
\hline RUBI & $\begin{array}{l}\text { Com relação à clareza do enunciado } \\
\text { Nota: } 5 \\
\text { Nota } \\
\text { Sugestões } \\
\text { Observações }\end{array}$ \\
\hline
\end{tabular}

\begin{tabular}{|l|l|}
\hline TOPÁzIo & $\begin{array}{l}\text { Com relação à clareza do enunciado } \\
\text { Nota: } 5 \\
\text { Nota }\end{array}$ \\
$\begin{array}{l}\text { Sugestões } \\
\text { Observações }\end{array}$ & Observações: não há. não há. \\
\hline
\end{tabular}

\begin{tabular}{|l|l|}
\hline ÁGUA-MARINHA & Com relação à clareza do enunciado \\
Nota & Nota: $\mathbf{5}$ \\
Sugestões & Sugestões: não há. \\
Observações & Observações: não há. \\
\hline
\end{tabular}

\begin{tabular}{|l|l|}
\hline ESMERALDA & Com relação à clareza do enunciado \\
Nota & Nota: 4 \\
Sugestões & Sugestões: não há. \\
\hline Observações & Observações: não há. \\
\hline
\end{tabular}

\begin{tabular}{|l|l|}
\hline JADE & Com relação à clareza do enunciado \\
Nota & Nota: $\mathbf{5}$ \\
Sugestões & Sugestões: não há \\
Observações & Observações: Enunciado muito grande \\
\hline
\end{tabular}

\begin{tabular}{|l|l|}
\hline SAFIRA & $\begin{array}{l}\text { Com relação à clareza do enunciado } \\
\text { Nota: } 5 \\
\text { Nota }\end{array}$ \\
$\begin{array}{l}\text { Sugestões } \\
\text { Observações }\end{array}$ & Observações: não há. não há. \\
\hline
\end{tabular}

\begin{tabular}{|l|l|}
\hline ÔNIX & Com relação à clareza do enunclado \\
Nota & Nota: 5 \\
Sugestões & Sugestőes: não há. \\
\hline Observações & Observações: não há. \\
\hline
\end{tabular}

\begin{tabular}{|l|l|}
\hline TURMALINA & Com relação à clareza do enunciado \\
Nota & Nota: 5 \\
Sugestões & Sugestões: não há. \\
Observações & Observações: não há. \\
\hline
\end{tabular}

\begin{tabular}{|l|l|}
\hline ÁGATA & Com relação à clareza do enunciado \\
Nota & Nota: $\mathbf{5}$ \\
Sugestões & Sugestões: não há. \\
Observações & Observações: não há. \\
\hline
\end{tabular}

\begin{tabular}{|l|l|}
\hline OPALA & $\begin{array}{l}\text { Com relação à clareza do enunciado } \\
\text { Nota: } 5 \\
\text { Sugestões }\end{array}$ \\
Observações & Sugestões: não há. $\quad$ Observações: não há. \\
\hline
\end{tabular}




\subsection{Apresentação dos dados relativos à $3^{a}$ aplicação da questão relativa a auxílio financeiro do instrumento, segundo a escala de Lickert}

Para a elaboração dessa análise, as notas dadas pelos juízes para cada questão do MMRI corresponderam a um peso assim definido:

1 - discordo totalmente

2 - discordo parcialmente

3 - indeciso

4 - concordo parcialmente

5- concordo totalmente

1) Apresentação dos dados relativos à clareza da pergunta de $n^{0} 5$ - Quem ajuda ou ajudaria o senhor(a) financeiramente, se precisar de auxílio para pagar aluguel da sua casa, pagar uma conta, comprar comida, remédio etc., pelo menos: Uma vez por semana? Uma vez por mês? Uma vez por ano? Segundo escala de Lickert, na $3^{\mathrm{a}}$ aplicação do MMRI.

\begin{tabular}{|l|c|}
\hline \multicolumn{1}{|c|}{ Nota/Conceito } & Freqüência \\
\hline 1 - Discordo totalmente & 0 \\
\hline 2 - Discordo parcialmente & 0 \\
\hline 3 - Indeciso & 0 \\
\hline 4 - Concordo parcialmente & 1 \\
\hline 5 - Concordo totalmente & 9 \\
\hline
\end{tabular}

$n=10$

CONCORDÂNCIA TOTAL $=100 \%$ 


\section{APRESENTAÇÃO E ANÁLISE DOS ESCORES ATRIBUÍDOS PELOS JUÍZES}

Nesta primeira parte da apresentação e análise dos resultados construímos, a partir dos dados coletados pela escala de Likert, tabelas e figuras que expressam os escores atribuídos pelos juízes nas três respostas.

Nas tabelas apresentamos as médias e medianas, mostrando as medidas de tendência central do instrumento, quanto ao seu questionário, e o desvio padrão de cada questão, caracterizando uma medida de dispersão dos escores dos juízes.

As Tabelas 1 a 6 apresentam as médias, medianas, desvios padrão e valores máximo e mínimo dos escores atribuídos às perguntas 1 a 5 na primeira resposta, 1 a 6 na segunda resposta, e 5 na terceira resposta, considerando a pertinência, clareza e forma de cada questão na ocasião em que essas características foram observadas. Vale lembrar que a última questão do instrumento se refere somente à sua apresentação gráfica, não sendo a ela atribuídos escores quanto à clareza, forma ou pertinência, e sim, quanto à sua adequação.

As perguntas 1 e 2 da segunda resposta resultaram de um desmembramento da pergunta 1 da primeira resposta e, por esta razão, os resultados referentes a essas questões são apresentados em uma mesma tabela.

Os resultados apresentados nas Tabelas 1 a 6 mostram que, na segunda resposta, e também na terceira no caso da pergunta 5 , as médias dos escores são superiores a 4 e as medianas iguais a 5 , o que significa que pelo menos $50 \%$ dos juízes atribuíram escore máximo às questões. Pelos valores observados dos desvios padrão, verifica-se que as avaliações dos juízes tornam-se mais homogêneas no decorrer das respostas (os desvios padrão diminuem da primeira resposta para a segunda e da segunda para a terceira). Particularmente, na avaliação da pertinência das questões 1 a 4 da primeira resposta, as médias dos escores foram maiores ou iguais a 4,6, sendo atribuído escore máximo (5) de forma unânime às perguntas 2 e 3 . $\mathrm{Na}$ segunda resposta, apenas a pertinência da questão relativa à identificação foi avaliada com escore 5 por parte de todos os juízes. 
Percebemos também que a média dos escores relativos à forma é maior que a dos relativos à clareza em todas as respostas e questões em que essas características foram avaliadas.

Esses resultados podem também ser visualizadas nas figuras 1 a 6 , nas quais estão representadas as médias (quadrados) e erros padrão (barras) dos escores observados em cada questão a cada resposta.

Nas figuras 7 a 10, podemos visualizar o comportamento individual dos juízes quanto aos escores por eles atribuídos nas diferentes questões e respostas. Notamos, de uma forma geral, a tendência de serem atribuídos maiores escores de uma resposta para outra. Observamos também que alguns juízes apresentaram comportamento diferente dos demais. Por exemplo, o juiz Topázio atribuiu escore 1 à clareza, forma e pertinência da questão 4 na primeira resposta, destacando-se dos demais juízes [gráficos 7(a), 8(a) e 9(a)]. Notamos também na figura 7(a), que o juiz Rubi atribuiu escores menores ou iguais a 3 a todas as perguntas na primeira resposta, destacando-se dos demais juízes.

Os dados relativos às médias encontradas no instrumento como um todo apontam para a obtenção de consenso na segunda aplicação, exceto para a pergunta de número 5 , que exigiu três envios. 
Tabela 1: Médias, medianas, desvios padrão, valores mínimos e máximos observados dos escores relativos à clareza e pertinência da apresentação dos dados de identificação, nas duas respostas

\begin{tabular}{clcc}
\hline & & Primeira resposta & Segunda resposta \\
\hline CLAREZA & Média & 4,40 & 4,80 \\
& Mediana & 5,00 & 5,00 \\
& Desvio Padrão & 0,97 & 0,42 \\
& Mínimo & 2,00 & 4,00 \\
\multirow{4}{*}{ PERTINÊNCIA } & Máximo & 5,00 & 5,00 \\
& Média & 4,60 & 5,00 \\
& Mediana & 5,00 & 5,00 \\
& Desvio Padrão & 0,70 & 0,00 \\
& Mínimo & 3,00 & 5,00 \\
& Máximo & 5,00 & 5,00 \\
\hline
\end{tabular}

Figura 1: Médias \pm erros padrão dos escores relativos à clareza e pertinência da apresentação dos dados de identificação, nas duas respostas

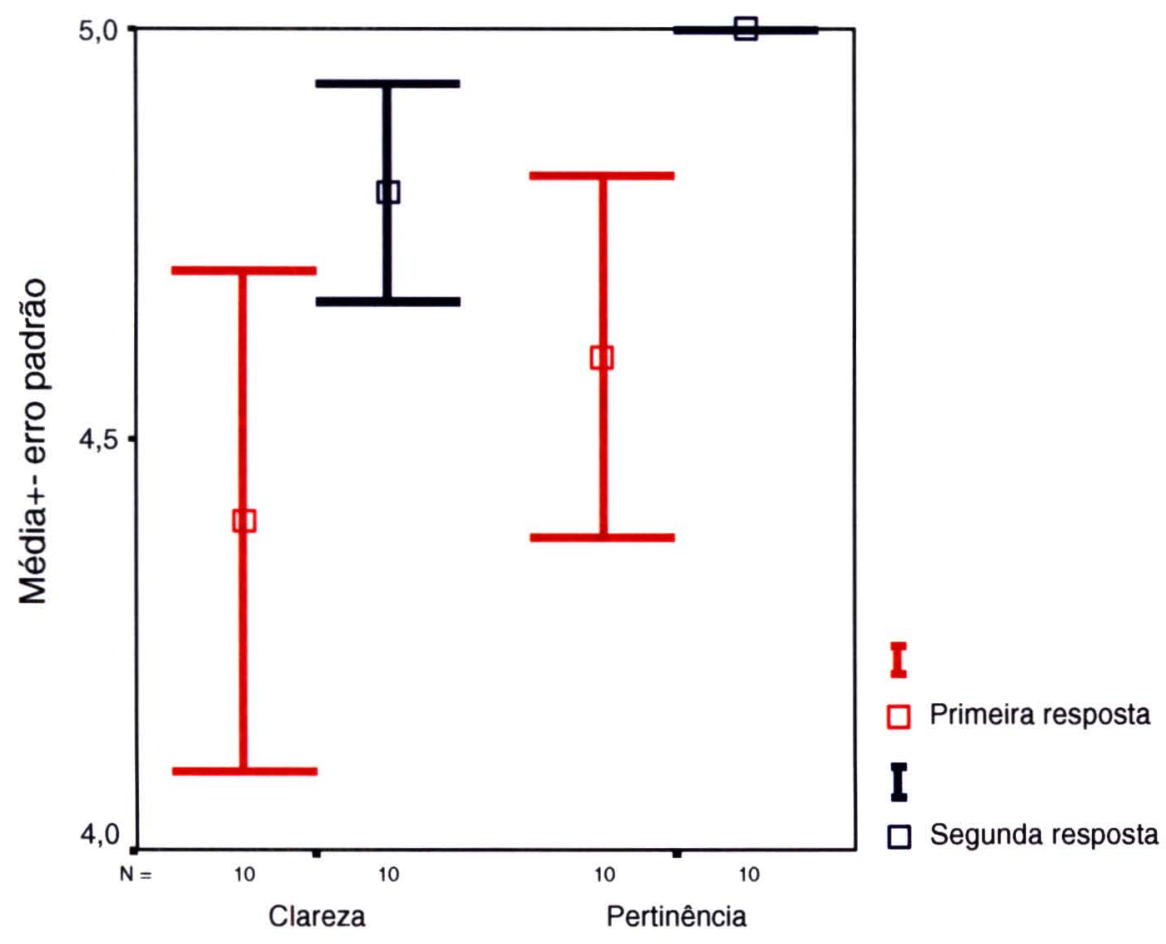

Os resultados indicaram a consistência do instrumento, verificada pela média obtida para as questões formuladas. Nota-se que para cada atributo das perguntas dos dados de identificação, clareza das perguntas e sua pertinência, a primeira aplicação tem médias inferiores que aumentaram na segunda análise dos juízes, obtendo essa questão um percentual de concordância ou um consenso bastante superior ao definido para o estudo e preconizado por SPÍNOLA $(1984,2002)$ e POLIT (1987). Já 
quanto à pertinência, observa-se pela figura acima que o consenso foi de $100 \%$ na segunda aplicação.

Tabela 2: Médias, medianas, desvios padrão, valores mínimos e máximos observados dos escores atribuídos pelos juizes à pergunta 1 na primeira resposta e perguntas 1 e 2 na segunda resposta

\begin{tabular}{llccc}
\hline & & Primeira resposta & \multicolumn{2}{c}{ Segunda resposta } \\
\cline { 2 - 5 } & & Pergunta 1 & Pergunta 1 & Pergunta 2 \\
\hline CLAREZA & Média & 3,80 & 4,90 & 4,80 \\
& Mediana & 3,50 & 5,00 & 5,00 \\
& Desvio Padrão & 0,92 & 0,32 & 0,42 \\
\multirow{5}{*}{ FORMA } & Mínimo & 3,00 & 4,00 & 4,00 \\
& Máximo & 5,00 & 5,00 & 5,00 \\
& Média & 4,40 & 4,90 & 4,90 \\
& Mediana & 4,50 & 5,00 & 5,00 \\
\multirow{5}{*}{ PERTINNENNCIA } & Mesvio Padrão & 0,70 & 0,32 & 0,32 \\
& Mínimo & 3,00 & 4,00 & 4,00 \\
& Máximo & 5,00 & 5,00 & 5,00 \\
& Mediana & 4,90 & Não foi aplicada & Não foi aplicada \\
& Desvio Padrão & 5,00 & Não foi aplicada & Não foi aplicada \\
& Mínimo & 0,32 & Não foi aplicada & Não foi aplicada \\
& Maximum & 4,00 & Não foi aplicada & Não foi aplicada \\
& & 5,00 & Não foi aplicada & Não foi aplicada \\
\hline
\end{tabular}

Figura 2: Médias \pm erros padrão dos escores atribuídos pelos juízes à pergunta 1 na primeira resposta e perguntas 1 e 2 na segunda resposta

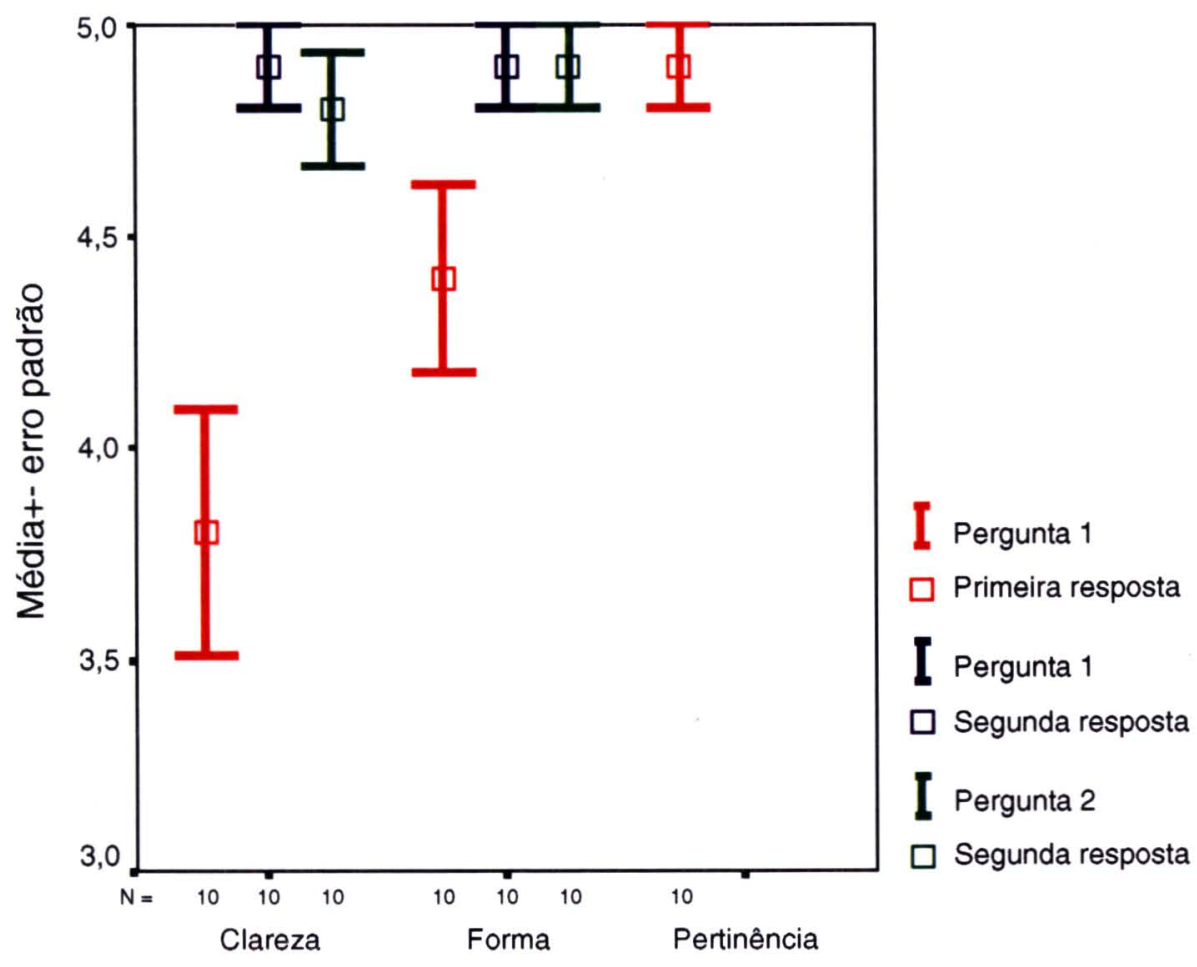


No resultado acima se verifica que a questão ficou abaixo da média preconizada para a pesquisa quanto ao item clareza da pergunta. A maioria dos especialistas julgou como pertinente a divisão da pergunta em duas, o que resultou num segundo envio com tais alterações. Na segunda aplicação, as médias, medianas e desvio padrão obtiveram um consenso superior ao definido para o estudo.

Quanto à forma de registro da questão, para aprimorar o ainda mais o instrumento, apesar de termos obtido o consenso necessário na primeira aplicação, optamos por enviá-la após a inclusão das sugestões referentes à clareza da pergunta, o que culminou numa concordância de $90 \%$ dos juízes.

O quesito referente à pertinência da pergunta, por obter consenso geral dos especialistas na primeira aplicação, não foi submetido à nova apreciação, sendo validado consensualmente em sua primeira aplicação.

Tabela 3: Médias, medianas, desvios padrão, valores mínimos e máximos observados dos escores atribuídos pelos juizes à pergunta 2 na primeira resposta e pergunta 3 na segunda resposta

\begin{tabular}{llcc}
\hline & & Primeira resposta & Segunda resposta \\
\cline { 3 - 4 } CLAREZA & Média & Pergunta 2 & Pergunta 3 \\
& Mediana & 4,20 & 4,80 \\
& Desvio Padrão & 4,50 & 5,00 \\
& Mínimo & 0,92 & 0,42 \\
\multirow{5}{*}{ FORMA } & Máximo & 3,00 & 4,00 \\
& Média & 5,00 & 5,00 \\
& Mediana & 4,70 & 4,90 \\
& Desvio Padrão & 5,00 & 5,00 \\
& Mínimo & 0,67 & 0,32 \\
PERTINÊNCIA & 3,00 & 4,00 \\
& Máximo & 5,00 & 5,00 \\
& Média & 5,00 & Não foi aplicada \\
& Mediana & 5,00 & Não foi aplicada \\
& Desvio Padrão & 0,00 & Não foi aplicada \\
& Mínimo & 5,00 & Não foi aplicada \\
& Maximum & 5,00 & Não foi aplicada \\
\hline
\end{tabular}


Figura 3: Médias \pm erros padrão dos escores atribuídos pelos juízes à pergunta 2 na primeira resposta e pergunta 3 na segunda resposta

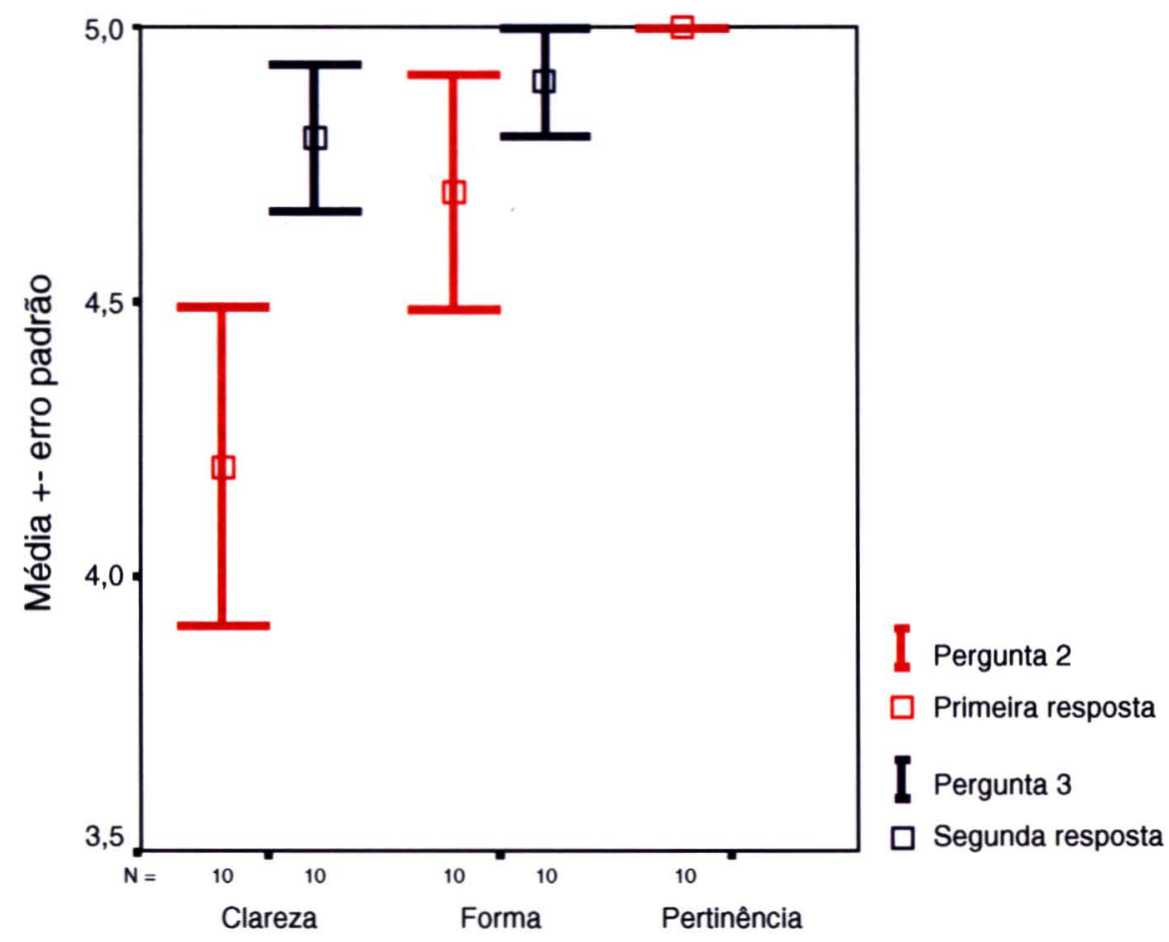

$\mathrm{Na}$ questão que avalia as atividades ou auxílios relativos aos serviços domésticos, os resultados mostram, a exemplo das perguntas anteriores, uma maior dispersão na primeira resposta quanto à clareza da pergunta. Na segunda aplicação, o percentual e consenso sobre esse quesito atinge $80 \%$, expresso pela média de 4,8 , ou seja, dos 10 juízes consultados 8 concordaram quanto à sua clareza. As notas não atingiram cifras maiores, pois, os juízes sugeriram tanto nessa questão, quanto nas demais que avaliaram funções relativas às atividades cotidianas desenvolvidas pelo idoso, exemplos de tais ações. Após a inclusão das sugestões relativas à clareza das perguntas, observamos a maior homogeneidade das notas com um percentual de concordância com esta na segunda aplicação com medianas de 5. 
Tabela 4: Médias, medianas, desvios padrão, valores mínimos e máximos observados dos escores atribuídos pelos juízes à pergunta 3 na primeira resposta e pergunta 4 na segunda resposta

\begin{tabular}{llcc}
\hline & & Primeira resposta & Segunda resposta \\
\cline { 3 - 4 } CLAREZA & Média & 3,90 & Pergunta 4 \\
& Mediana & 4,00 & 4,90 \\
& Desvio Padrão & 0,74 & 5,00 \\
\multirow{5}{*}{ FORMA } & Mínimo & 3,00 & 0,32 \\
& Máximo & 5,00 & 4,00 \\
& Média & 4,70 & 5,00 \\
& Mediana & 5,00 & 4,90 \\
\multirow{3}{*}{ PERTINÊNCIA } & 0,67 & 5,00 \\
& Desvio Padrão & 3,00 & 0,32 \\
& Mínimo & 5,00 & 4,00 \\
& Máximo & 5,00 & 5,00 \\
& Média & 5,00 & Não foi aplicada \\
& Mediana & 0,00 & Não foi aplicada \\
& Desvio Padrão & 5,00 & Não foi aplicada \\
& Mínimo & Não foi aplicada \\
& Máximo & 5,00 & Não foi aplicada \\
\hline
\end{tabular}

Figura 4: Médias \pm erros padrão dos escores atribuídos pelos juízes à pergunta 3 na primeira resposta e pergunta 4 na segunda resposta

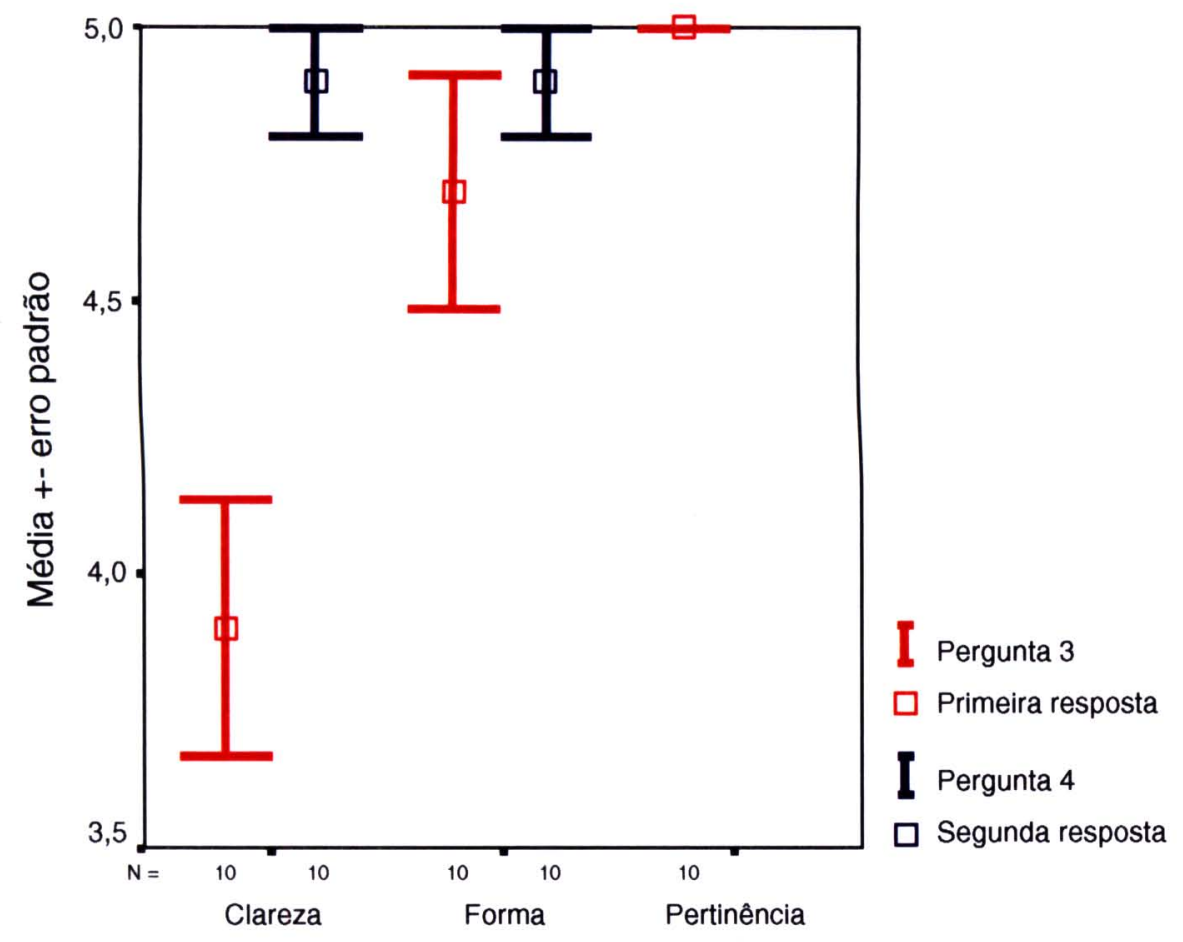

Na questão que avalia as atividades ou auxílios relativos aos cuidados pessoais, os resultados mostram, a exemplo das perguntas anteriores, uma maior 
dispersão na primeira resposta quanto à clareza da pergunta. Na segunda aplicação, o percentual de consenso sobre esse quesito atinge $80 \%$, expresso pela média de 4,9 , ou seja, dos 10 juízes consultados, 9 concordaram quanto à sua clareza. As notas não atingiram cifras maiores, por esses juizes sugerirem a inclusão de exemplos de tais ações. Após a inclusão das sugestões relativas à clareza das perguntas, observamos a maior homogeneidade das notas com um percentual de concordância com esta na segunda aplicação com medianas de 5 .

Tabela 5: Médias, medianas, desvios padrão, valores mínimos e máximos observados dos escores atribuídos pelos juizes à pergunta 4 na primeira resposta e pergunta 5 na segunda e terceira respostas.

\begin{tabular}{llccc}
\hline & & $\begin{array}{c}\text { Primeira } \\
\text { resposta }\end{array}$ & $\begin{array}{c}\text { Segunda } \\
\text { resposta }\end{array}$ & $\begin{array}{c}\text { Terceira } \\
\text { resposta }\end{array}$ \\
\hline CLAREZA & Pergunta 4 & Pergunta 5 & Pergunta 5 \\
& Média & 3,80 & 4,60 & 4,90 \\
& Mediana & 4,00 & 5,00 & 5,00 \\
& Desvio Padrão & 1,32 & 0,70 & 0,32 \\
& Mínimo & 1,00 & 3,00 & 4,00 \\
FORMA & Máximo & 5,00 & 5,00 & 5,00 \\
& Média & 4,50 & 4,90 & 5,00 \\
& Mediana & 5,00 & 5,00 & 5,00 \\
& Desvio Padrão & 1,27 & 0,32 & 0,00 \\
& Mínimo & 1,00 & 4,00 & 5,00 \\
& Máximo & 5,00 & 5,00 & 5,00 \\
& Média & 4,60 & Não foi aplicada & Não foi aplicada \\
& Mediana & 5,00 & Não foi aplicada & Não foi aplicada \\
& Desvio Padrão & 1,26 & Não foi aplicada & Não foi aplicada \\
& Mínimo & 1,00 & Não foi aplicada & Não foi aplicada \\
& Máximo & 5,00 & Não foi aplicada & Não foi aplicada \\
\hline
\end{tabular}


Figura 5: Médias \pm erros padrão dos escores atribuídos pelos juízes à pergunta 4 na primeira resposta e pergunta 5 na segunda e terceira respostas

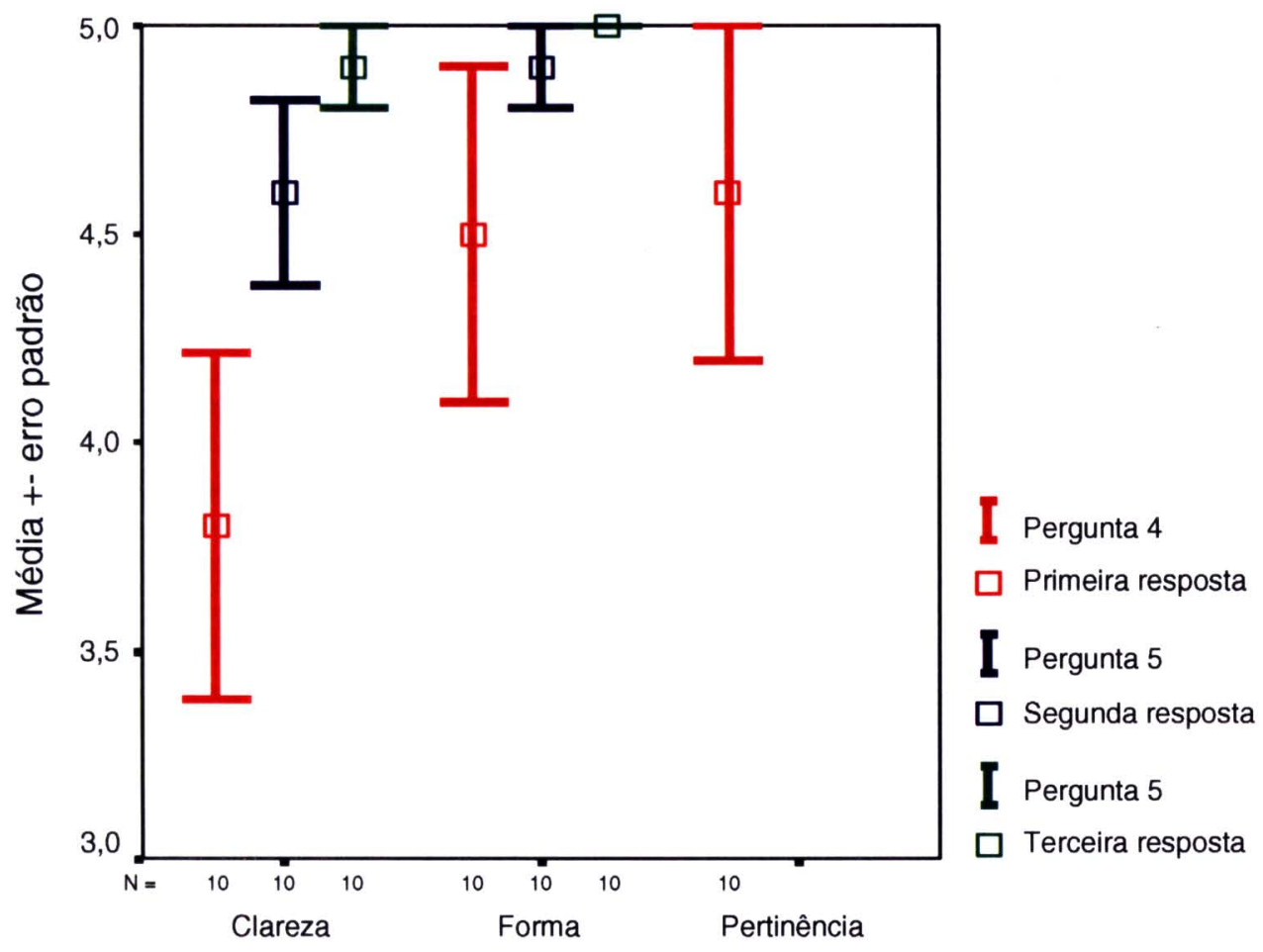

Na questão que avalia o fornecimento ou possibilidade do auxílio financeiro, os resultados também expressam, a exemplo das perguntas anteriores, uma maior dispersão na primeira resposta quanto à clareza da pergunta. Na segunda aplicação, o percentual de consenso sobre esse quesito atingiu o percentual de $60 \%$, ainda insuficiente para a validação consensual do instrumento. Dessa maneira, para essa questão foi necessária uma terceira aplicação. Após a incorporação das sugestões enviadas pelos juízes, para que se deixasse o enunciado mais claro, a questão atingiu, na sua terceira e última aplicação, praticamente $100 \%$ de concordância quanto à clareza. Ressaltamos que a terceira aplicação foi realizada apenas com o quesito de clareza da pergunta, pois os demais obtiveram opinião convergente nas aplicações anteriores. 
Tabela 6: Médias, medianas, desvios padrão, valores mínimos e máximos observados dos escores atribuidos pelos juízes à apresentação gráfica do instrumento na primeira e na segunda resposta

\begin{tabular}{lcc}
\hline & Primeira resposta & Segunda resposta \\
\hline Média & 4,70 & 4,90 \\
Mediana & 5,00 & 5,00 \\
Desvio Padrão & 0,48 & 0,32 \\
Mínimo & 4,00 & 4,00 \\
Máximo & 5,00 & 5,00 \\
\hline
\end{tabular}

Figura 6: Médias \pm erros padrão dos escores atribuidos pelos juízes à apresentação gráfica do instrumento na primeira e na segunda resposta

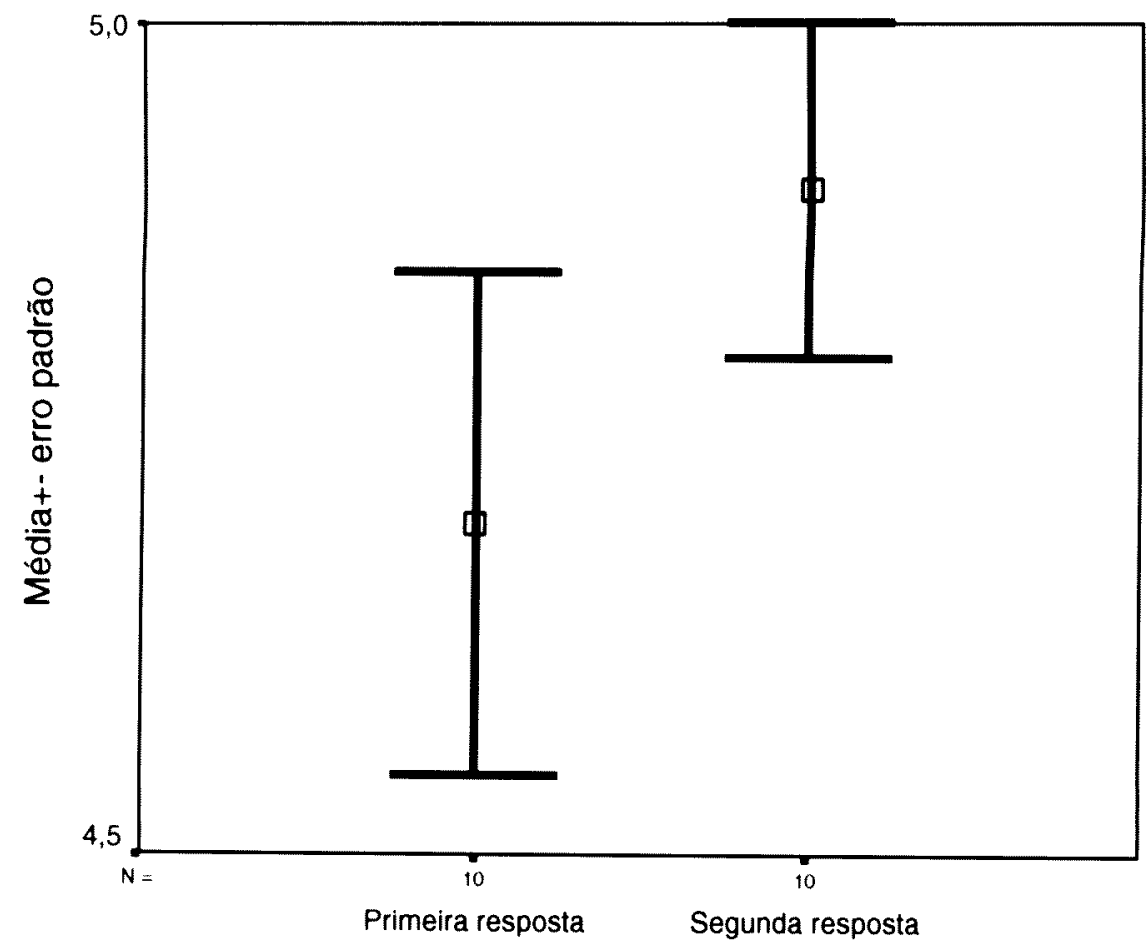

Quanto à apresentação gráfica do instrumento, já na primeira aplicação os dados apontam para $80 \%$ de convergência. Mesmo com o consenso mínimo obtido, optamos por enviar novamente a questão, uma vez que outros itens do instrumento foram ajustados. $\mathrm{Na}$ segunda aplicação, o escore obtido foi de convergência ou de aceitação da forma de registro, com $90 \%$ de congruência. 


\section{APRESENTAÇÃO E ANÁLISE DAS SUGESTÕES E OBSERVAÇÕES FORMULADAS PELOS JUÍZES}

As sugestões e observações formuladas pelos juízes quanto à clareza, pertinência e forma das perguntas, nas três respostas, foram categorizadas em: enunciado, referencial, treinamento e sem sugestões e sem observações e analisadas de forma descritiva por meio da construção de gráficos de barras (Figuras 11 a 25). A altura de cada barra representa a freqüência observada de cada categoria de sugestão e observação. Notamos nessas figuras que, de uma forma geral, o número de categorias em uma mesma questão diminui da primeira para a segunda resposta e da segunda para a terceira, ocorrendo um aumento na freqüência da categoria em que não houve sugestões e observações. A freqüência desta categoria é superior a 8 para todas as questões da segunda resposta, tanto para clareza, forma e pertinência (nas perguntas em que foi avaliada) exceto para o item clareza da pergunta 5 . Isto significa que 8 ou mais juízes não fizeram sugestões ou observações na segunda resposta em nenhuma das questões, exceto na 5 , quanto à clareza. $\mathrm{Na}$ terceira resposta, entretanto, nenhum juiz fez sugestões ou observações relativas à clareza dessa pergunta. 
Figura 7: Gráfico das freqüências observadas de cada categoria de sugestão - observação para clareza da pergunta de identificação na primeira e segunda respostas

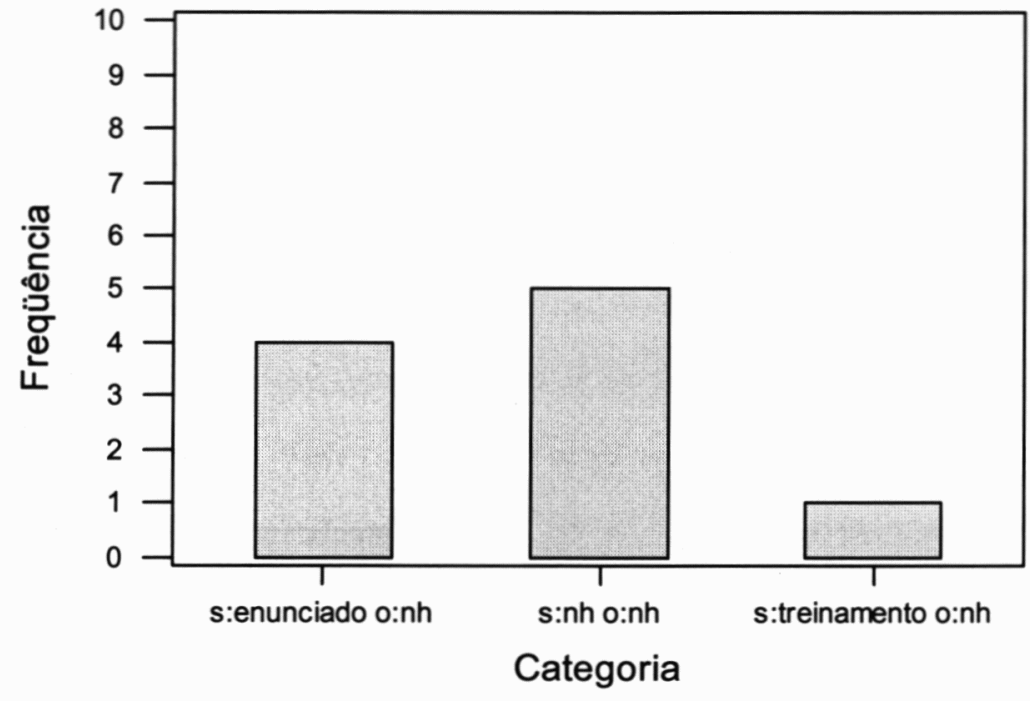

(a) Primeira resposta

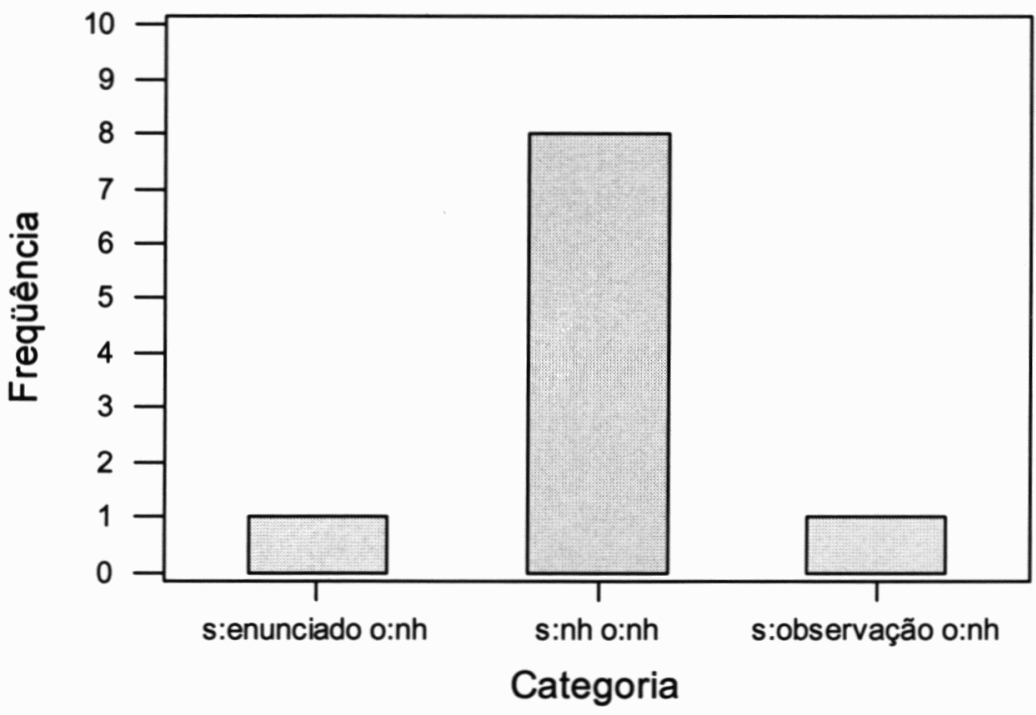

(b) Segunda resposta 
Figura 8: Gráfico das freqüências observadas de cada categoria de sugestão - observação para pertinência da pergunta de identificação na primeira e segunda respostas

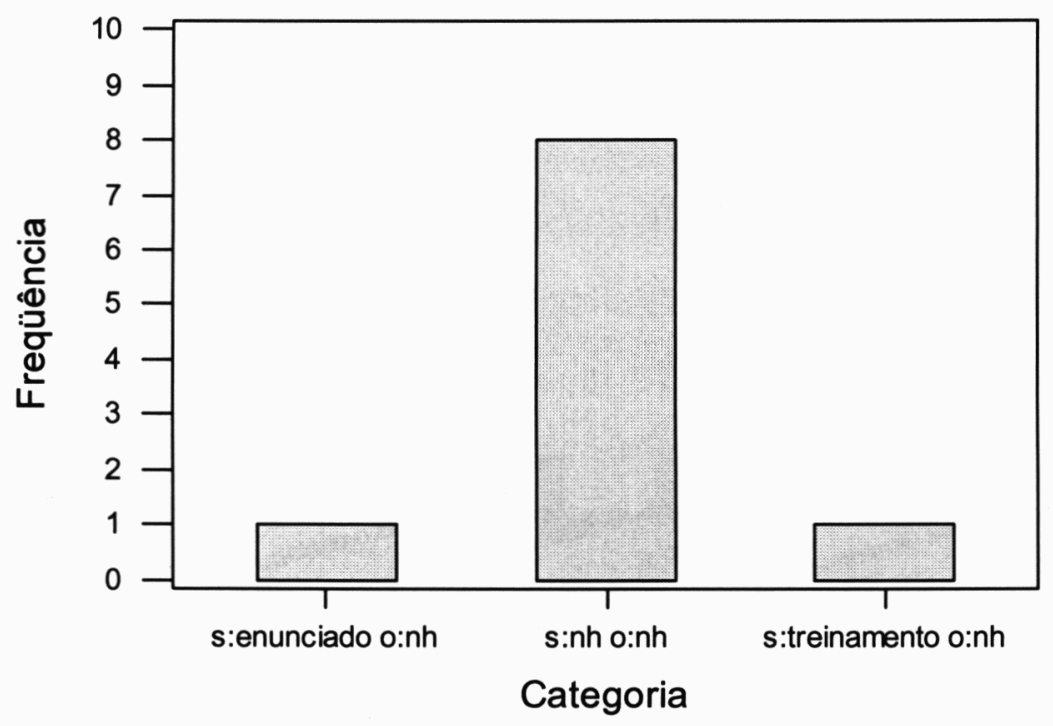

(a) Primeira resposta

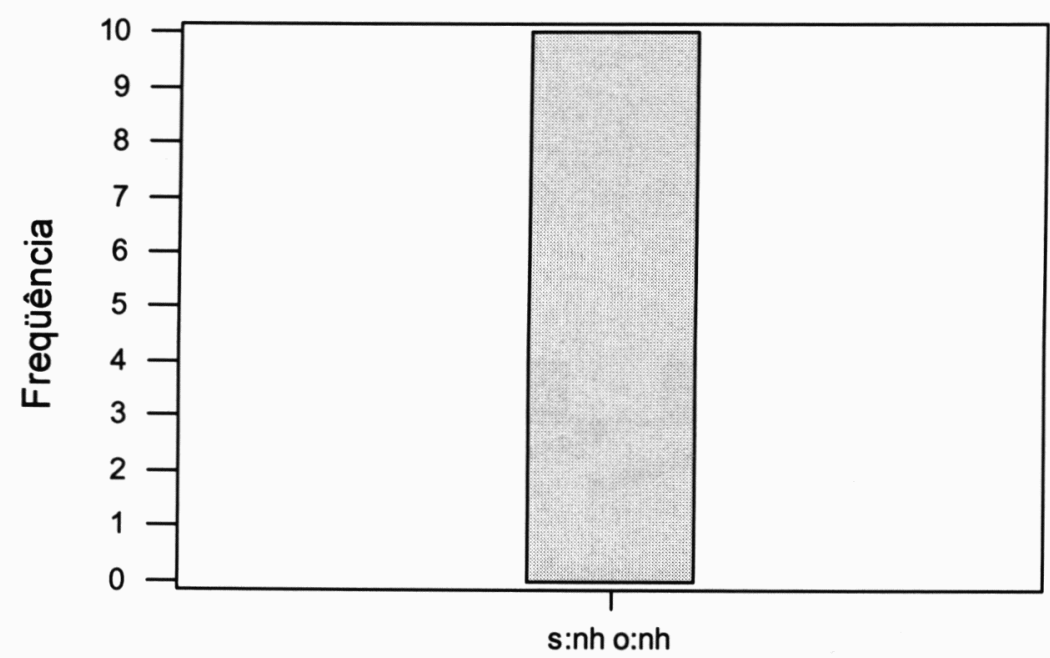

Categoria

\section{(b) Segunda resposta}


Figura 9: Gráfico das frequêêcias observadas de cada categoria de sugestão - observação para clareza da pergunta 1 na primeira e perguntas 1 e 2 na segunda resposta

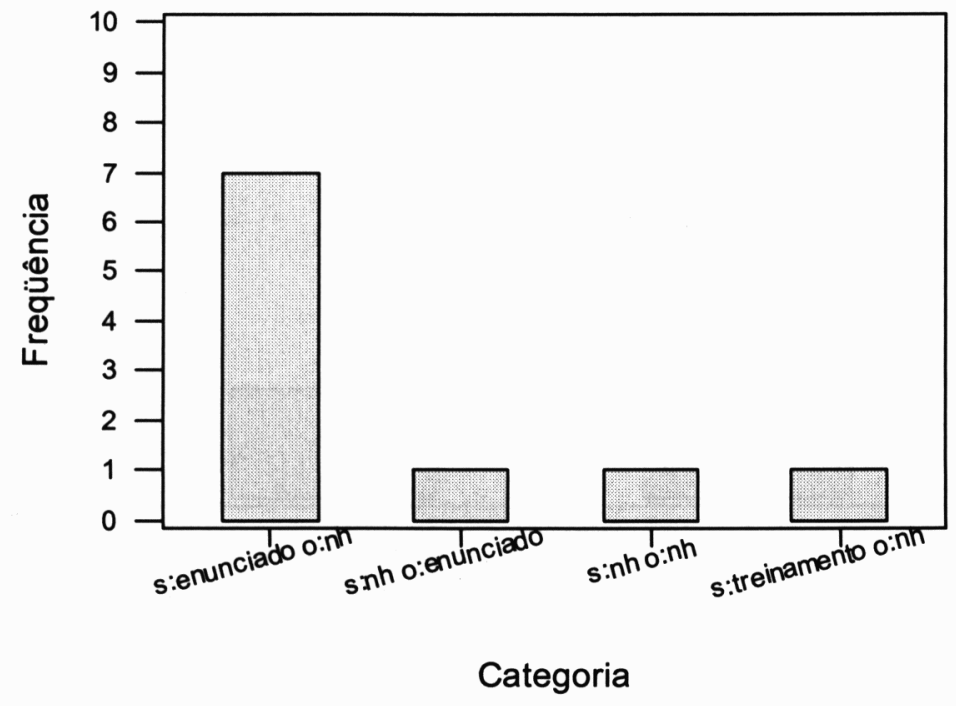

(a) Primeira resposta

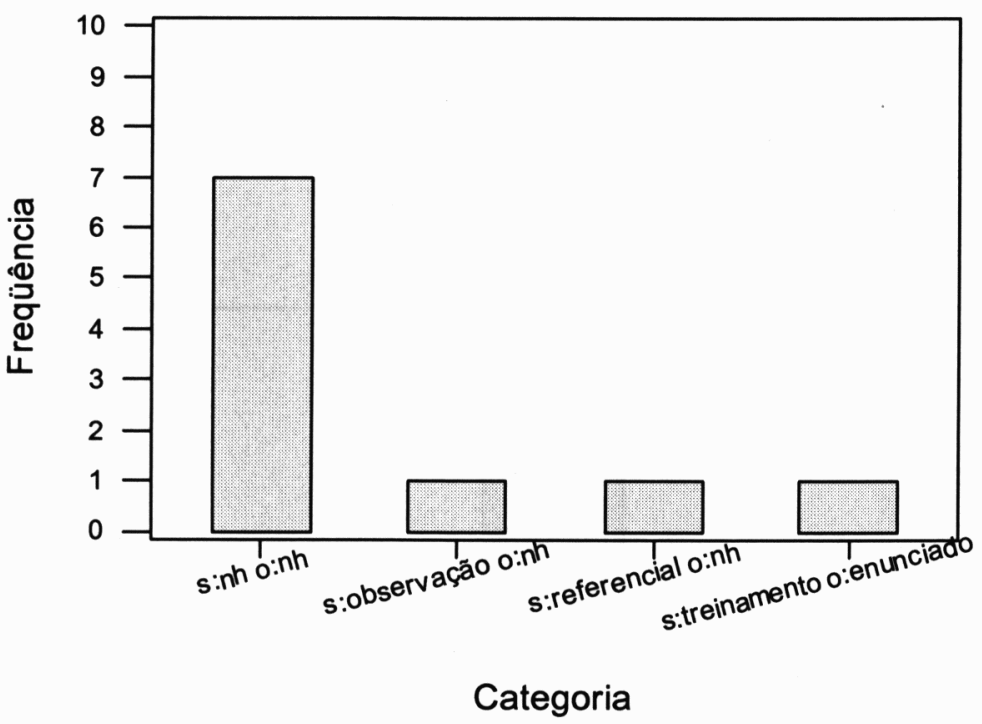

(b) Segunda resposta - Pergunta 1 


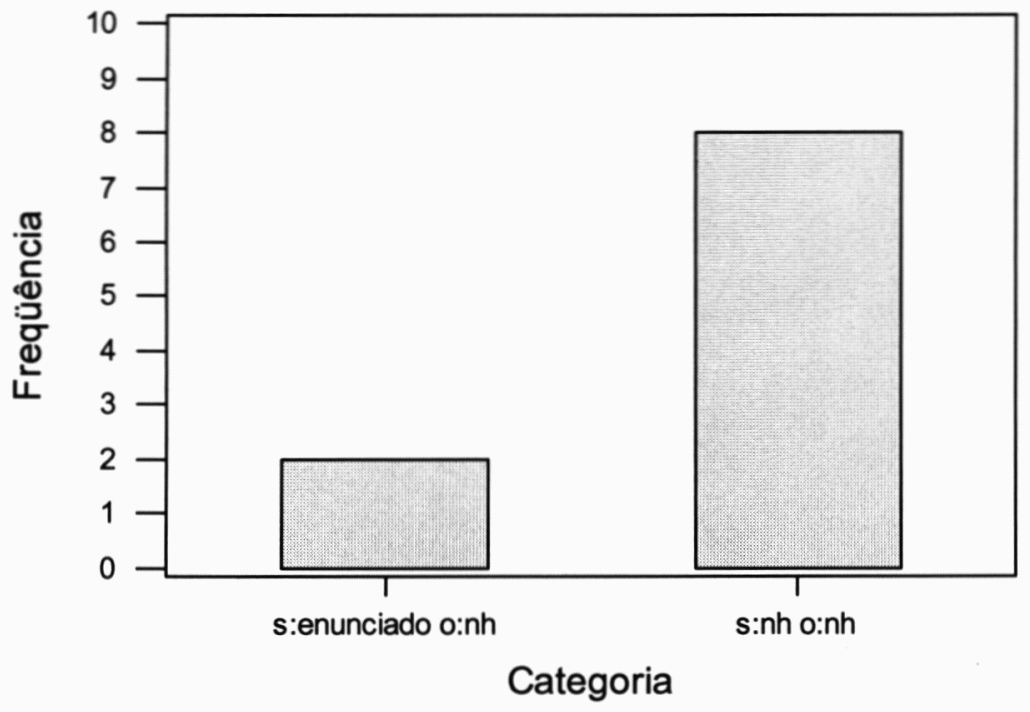

(c) Segunda resposta - Pergunta 2

Figura 10: Gráfico das frequeências observadas de cada categoria de sugestão - observação para pertinência da pergunta 1 na primeira resposta

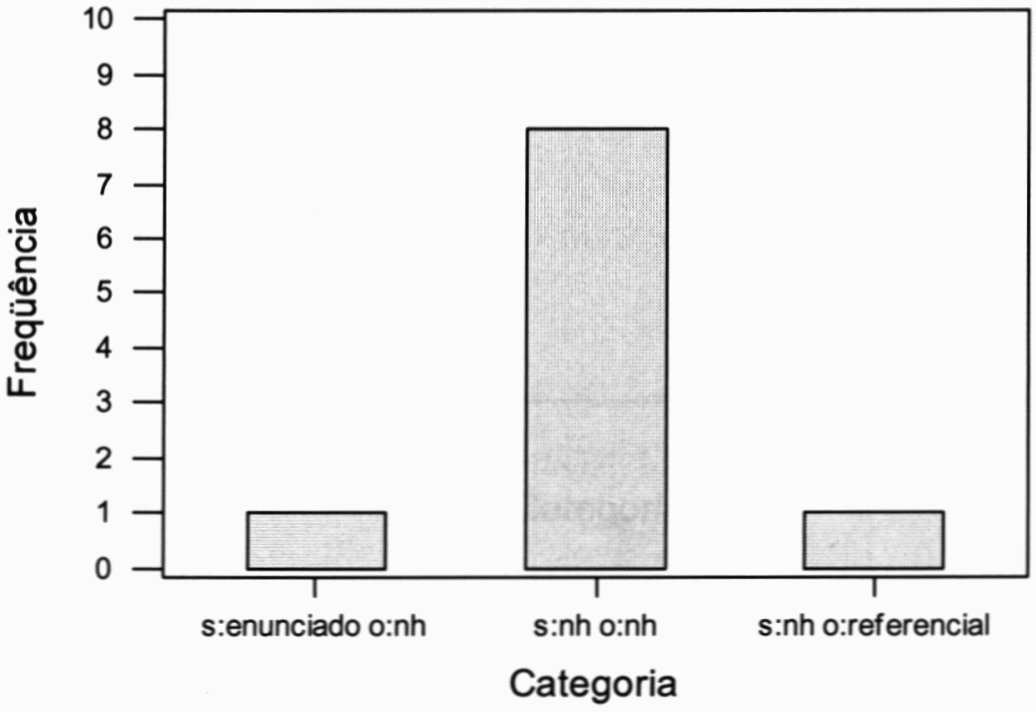


Figura 11: Gráfico das freqüências observadas de cada categoria de sugestão - observação para forma da pergunta 1 na primeira e perguntas 1 e 2 na segunda resposta

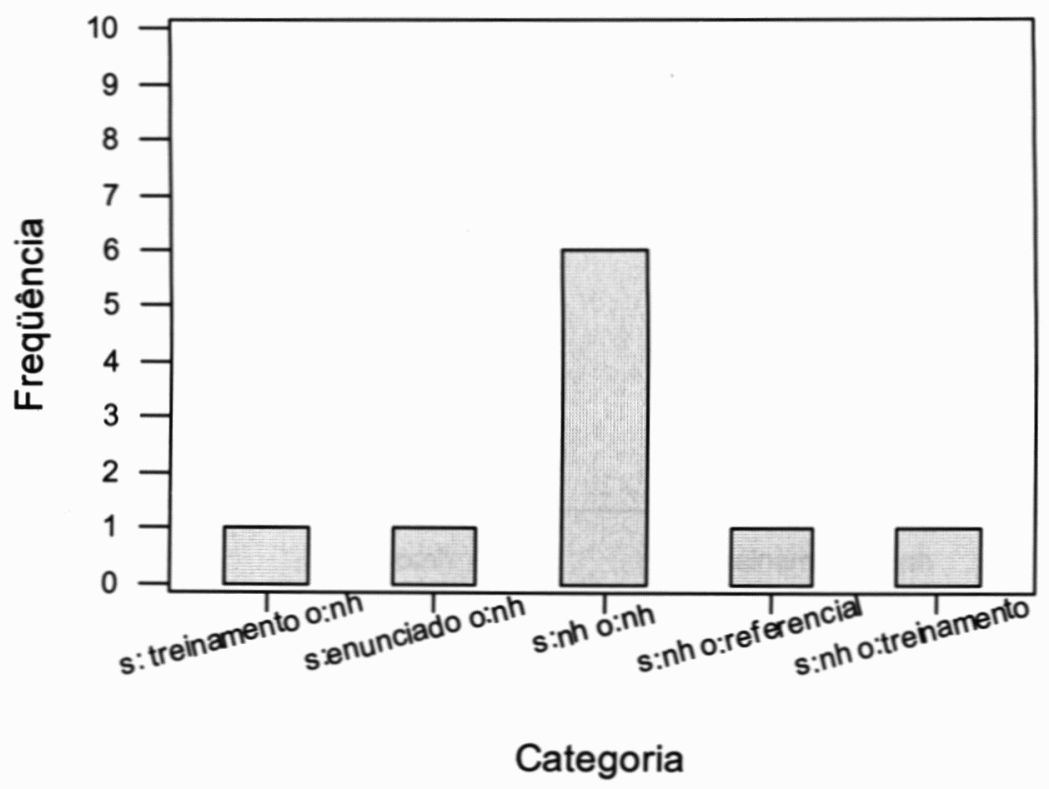

(a) Primeira resposta

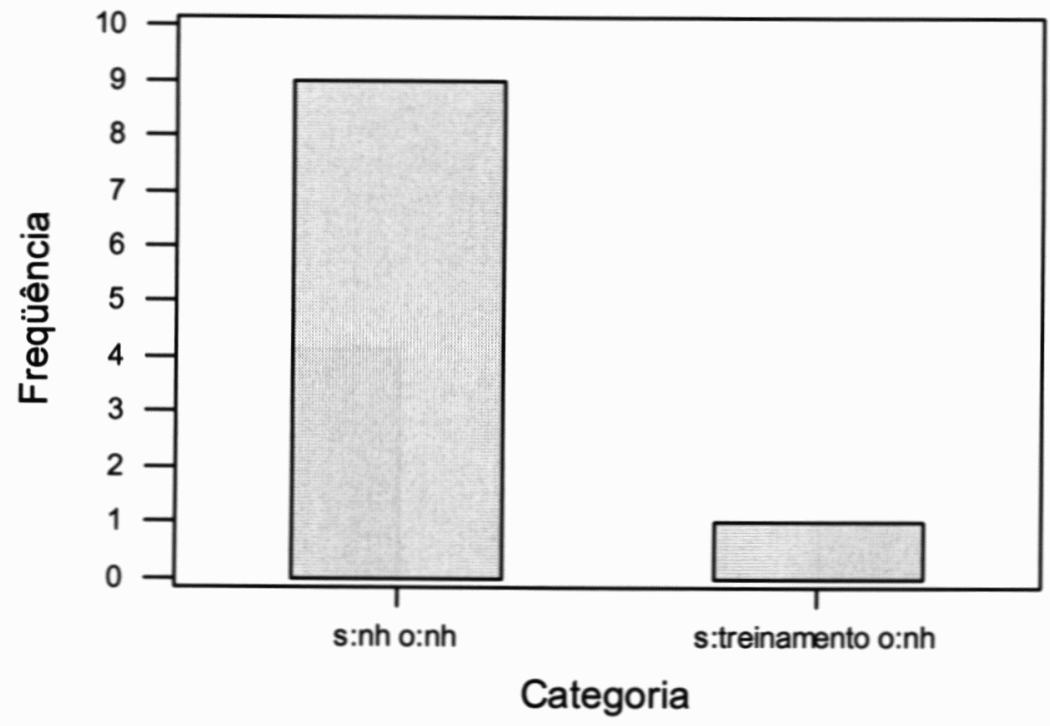

(b) Segunda resposta - Pergunta 1 


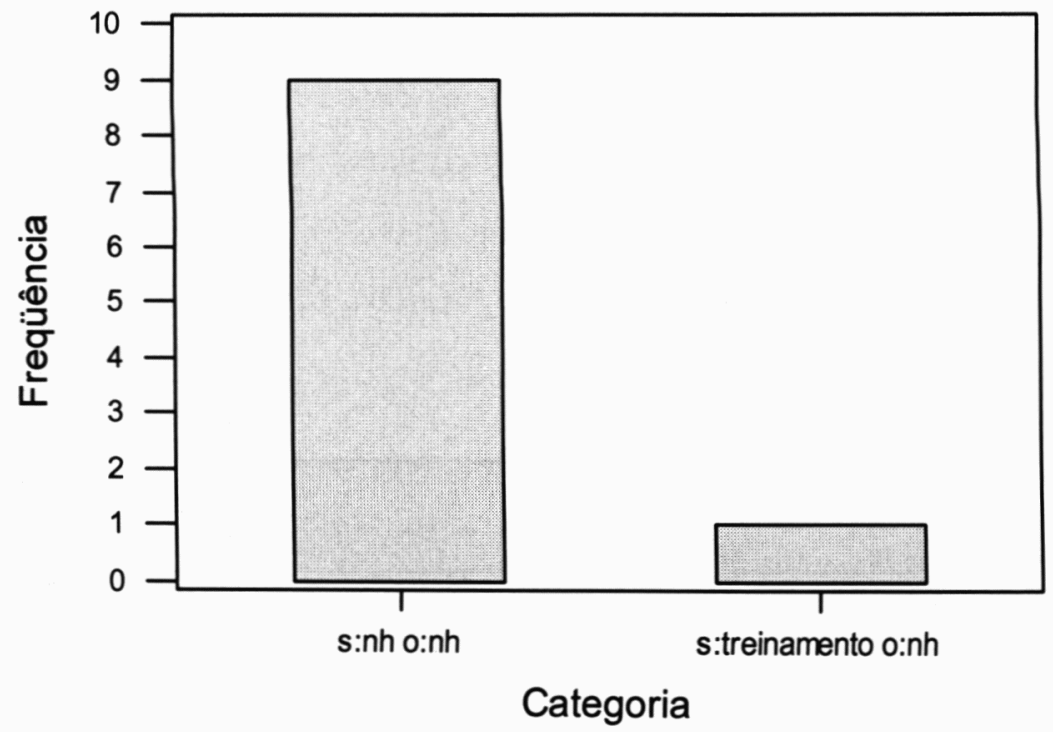

(c) Segunda resposta - Pergunta 2

Figura 12: Gráfico das freqüências observadas de cada categoria de sugestão - observação para clareza da pergunta 2 na primeira resposta e da pergunta 3 na segunda resposta

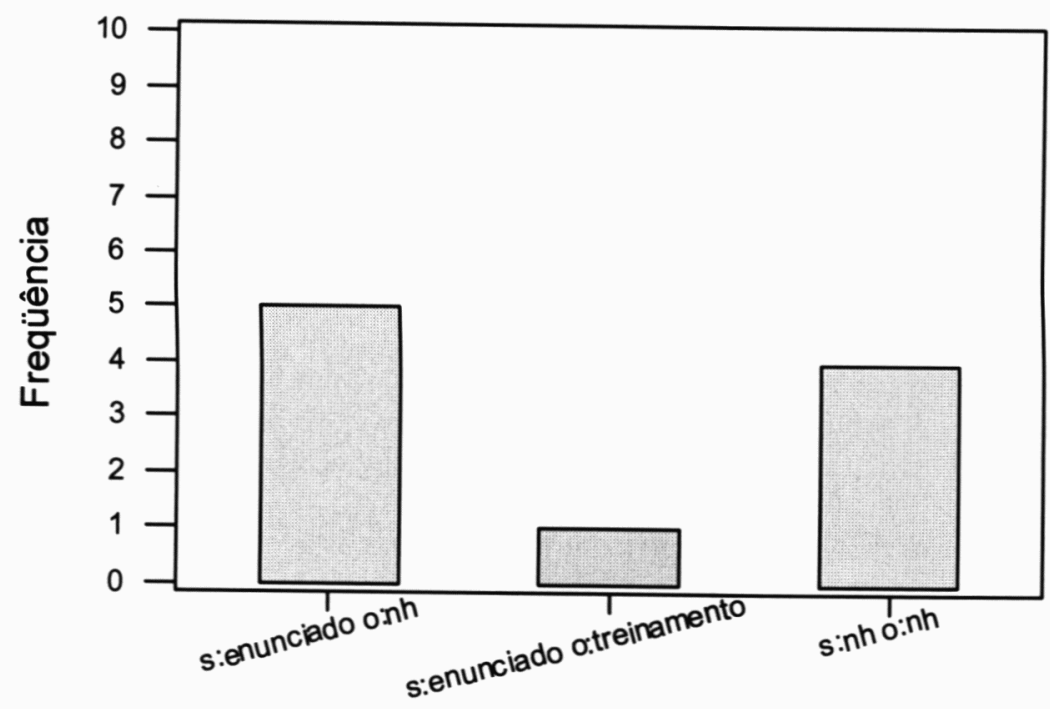

Categoria

Primeira resposta - Pergunta 2 


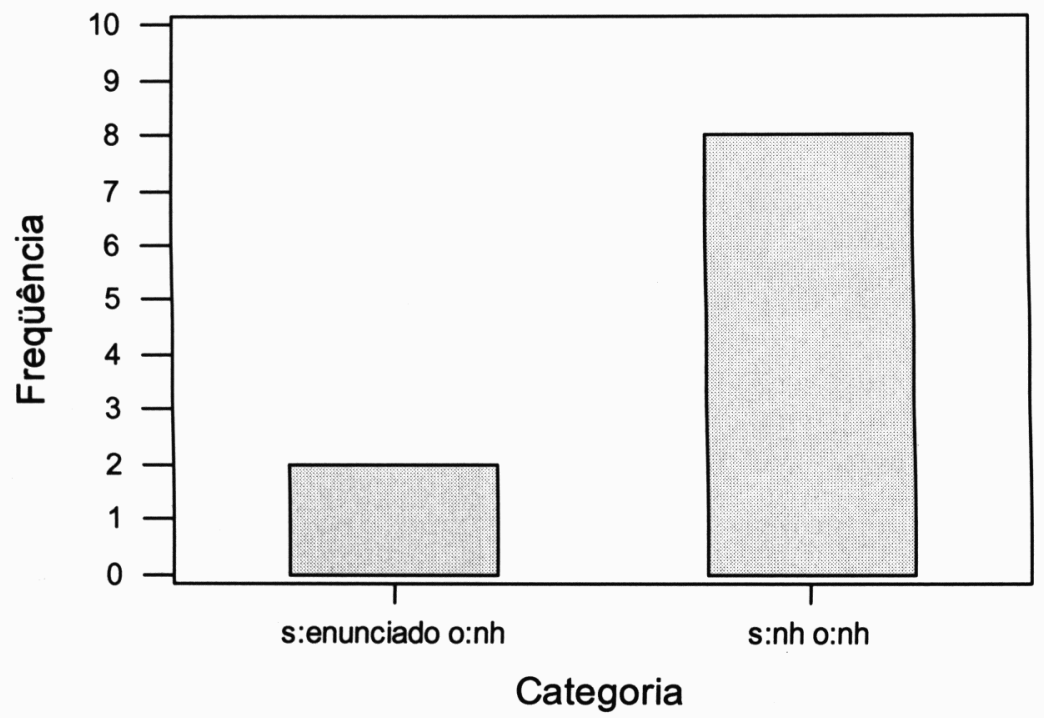

(b) Segunda resposta - Pergunta 3

Figura 13: Gráfico das freqüências observadas de cada categoria de sugestão - observação para pertinência da pergunta 2 na primeira resposta

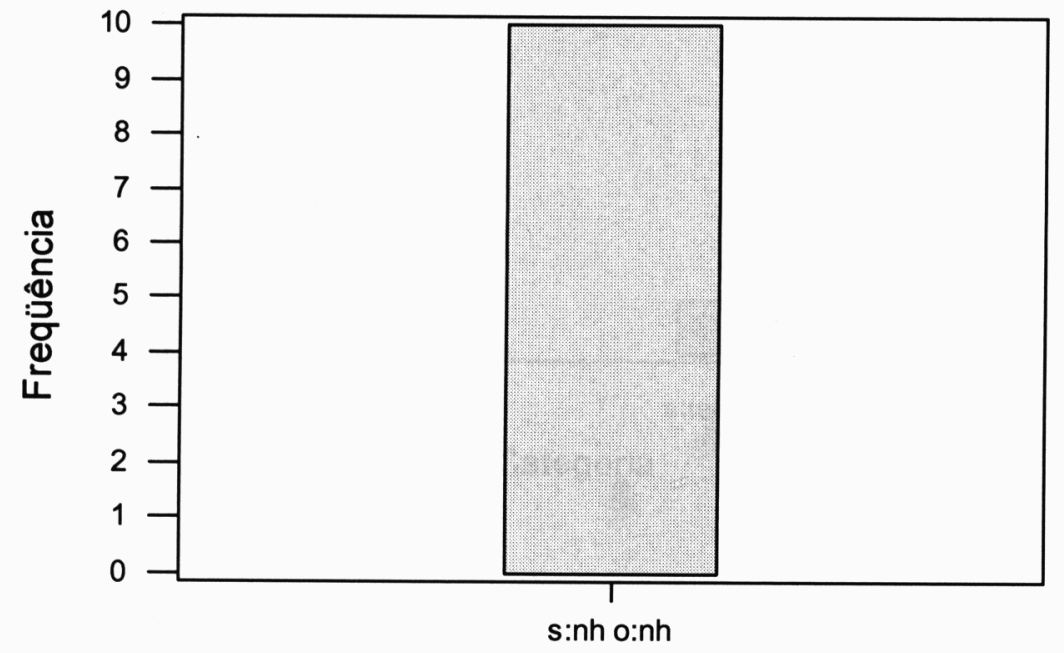

Categoria 
Figura 14: Gráfico das freqüências observadas de cada categoria de sugestão - observação para forma da pergunta 2 na primeira resposta e da pergunta 3 na segunda resposta

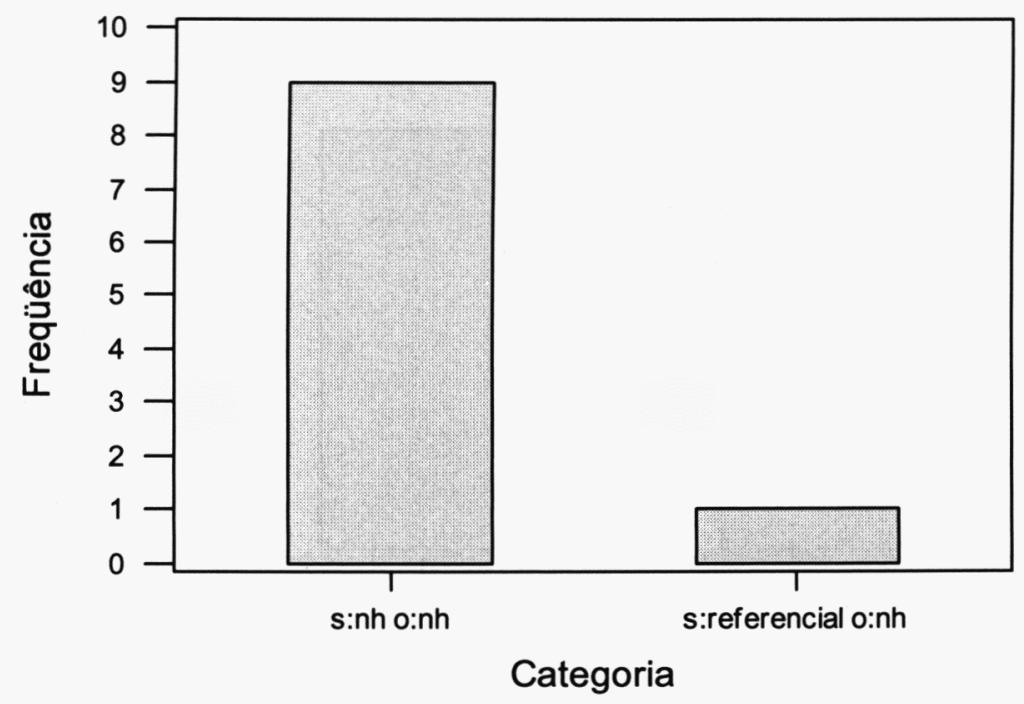

Primeira resposta - Pergunta 2

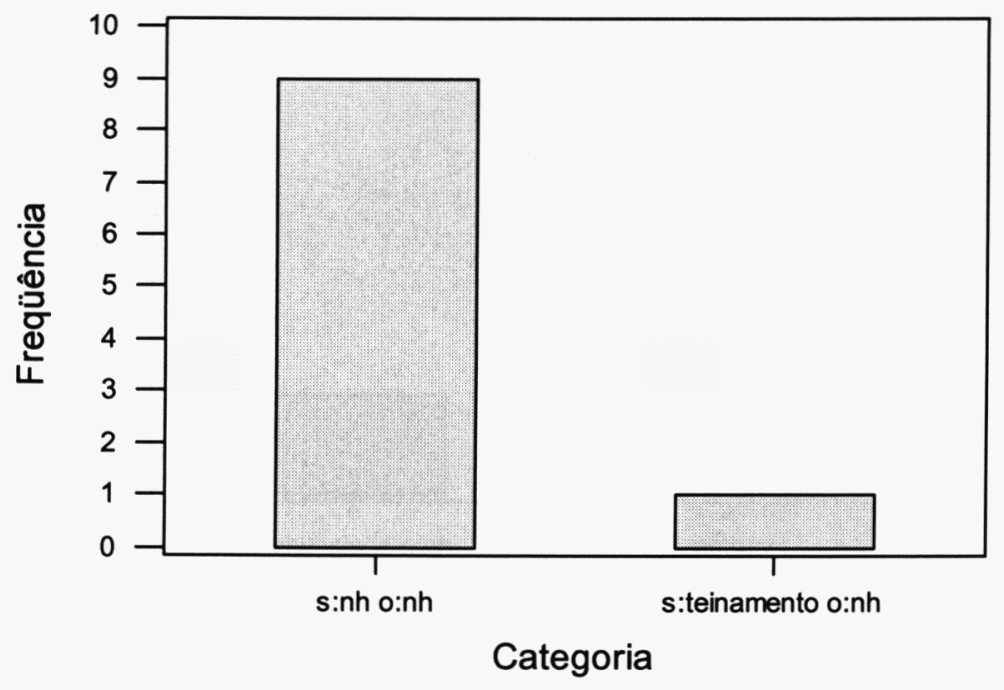

(b) Segunda resposta - Pergunta 3 
Figura 15: Gráfico das freqüências observadas de cada categoria de sugestão - observação para clareza da pergunta 3 na primeira resposta e da pergunta 4 na segunda resposta

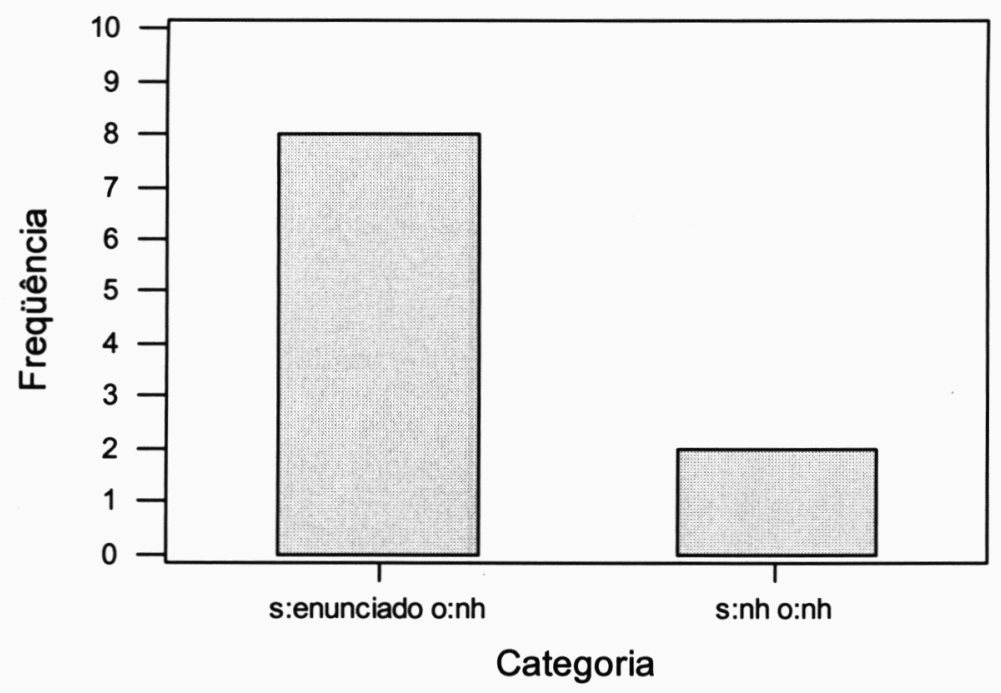

Primeira resposta - Pergunta 3

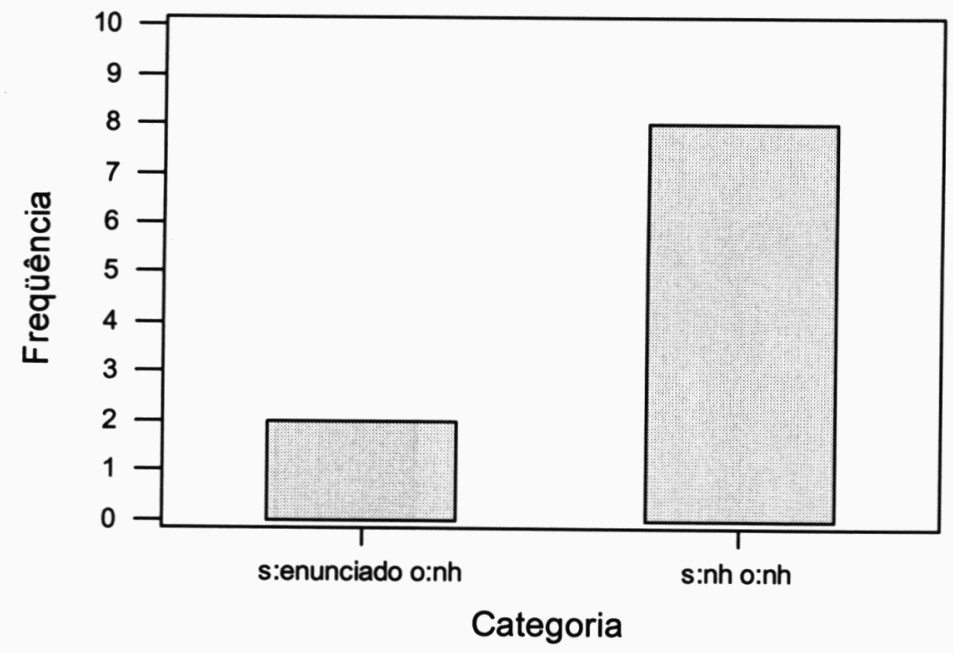

(b) Segunda resposta - Pergunta 4 
Figura 16: Gráfico das frequêencias observadas de cada categoria de sugestão - observação para pertinência da pergunta 3 na primeira resposta

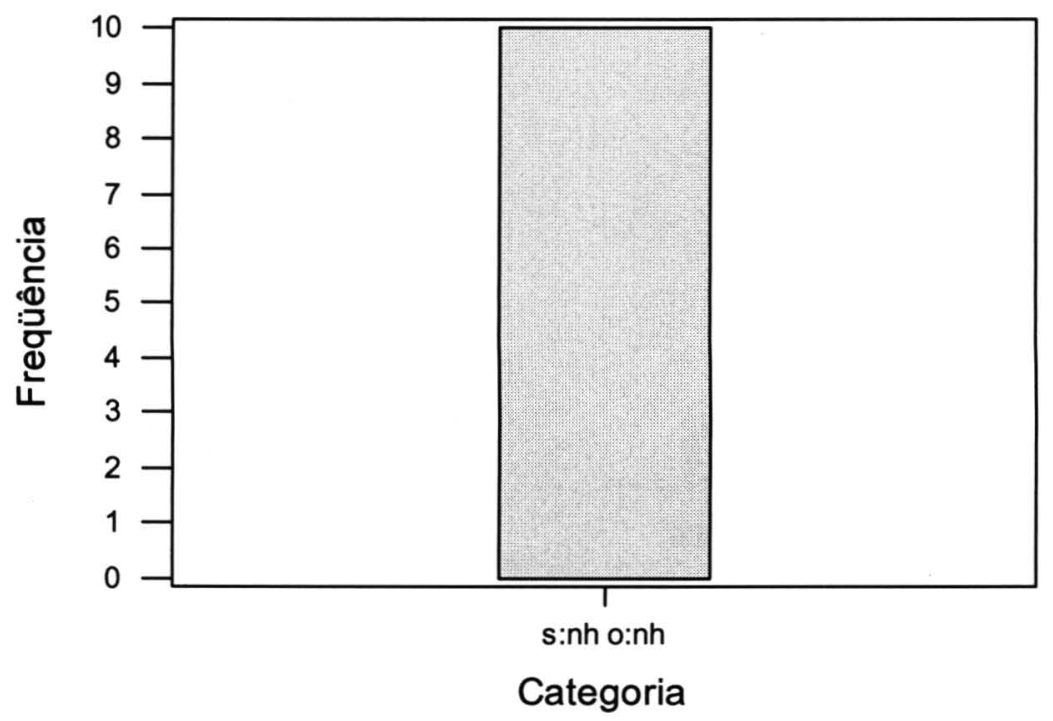

Figura 17: Gráfico das freqüências observadas de cada categoria de sugestão - observação para forma da pergunta 3 na primeira resposta e da pergunta 4 na segunda resposta

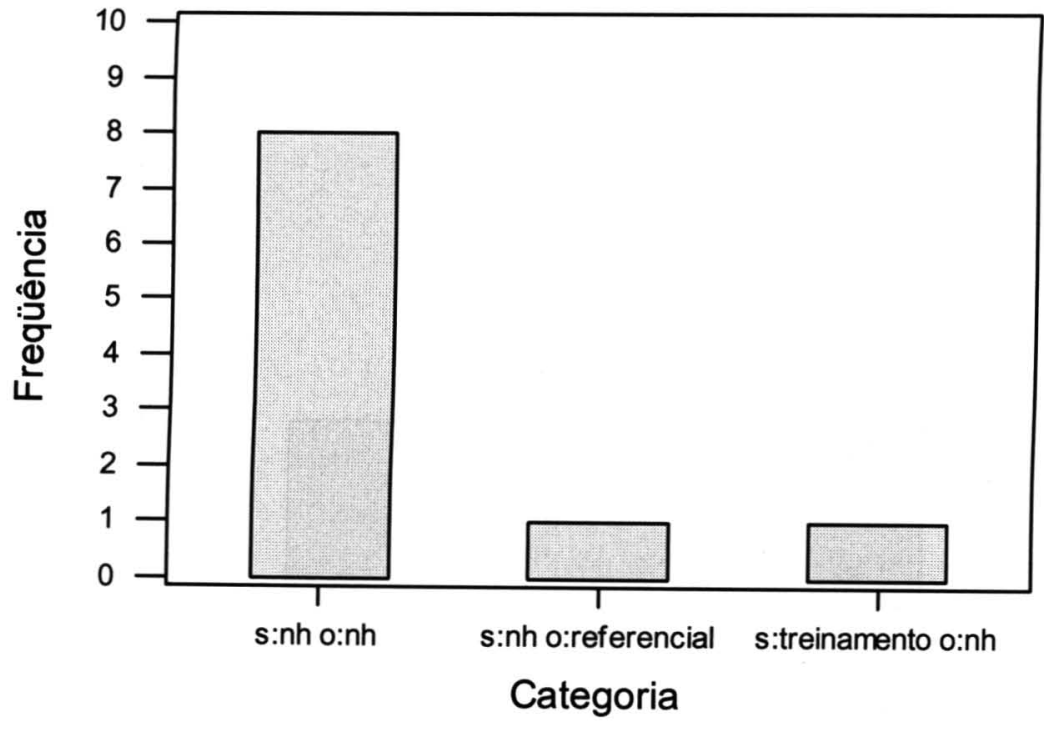

Primeira resposta - Pergunta 3 


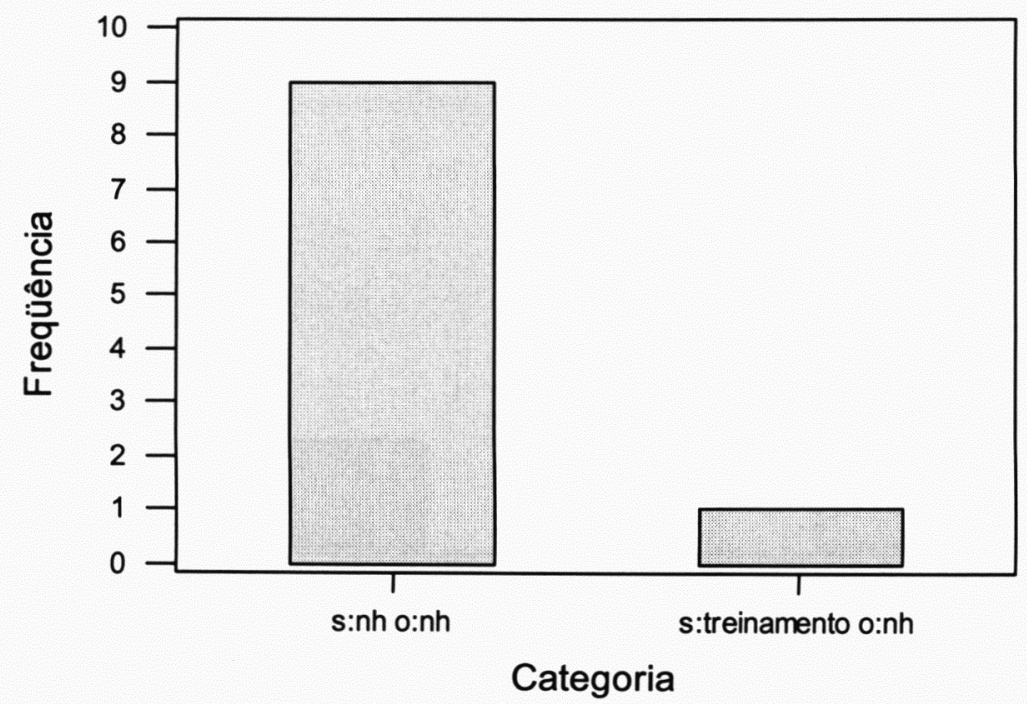

(b) Segunda resposta - Pergunta 4

Figura 18: Gráfico das freqüências observadas de cada categoria de sugestão - observação para clareza da pergunta 4 na primeira resposta e da pergunta 5 na segunda e terceira respostas

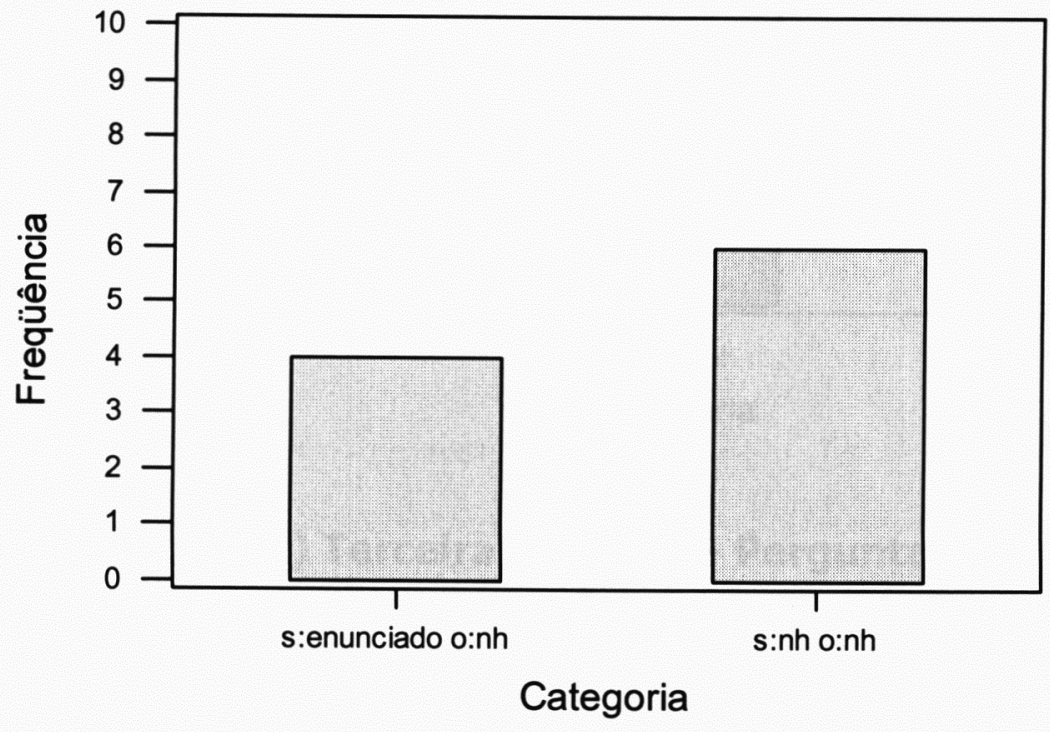

(a) Primeira resposta - Pergunta 4 


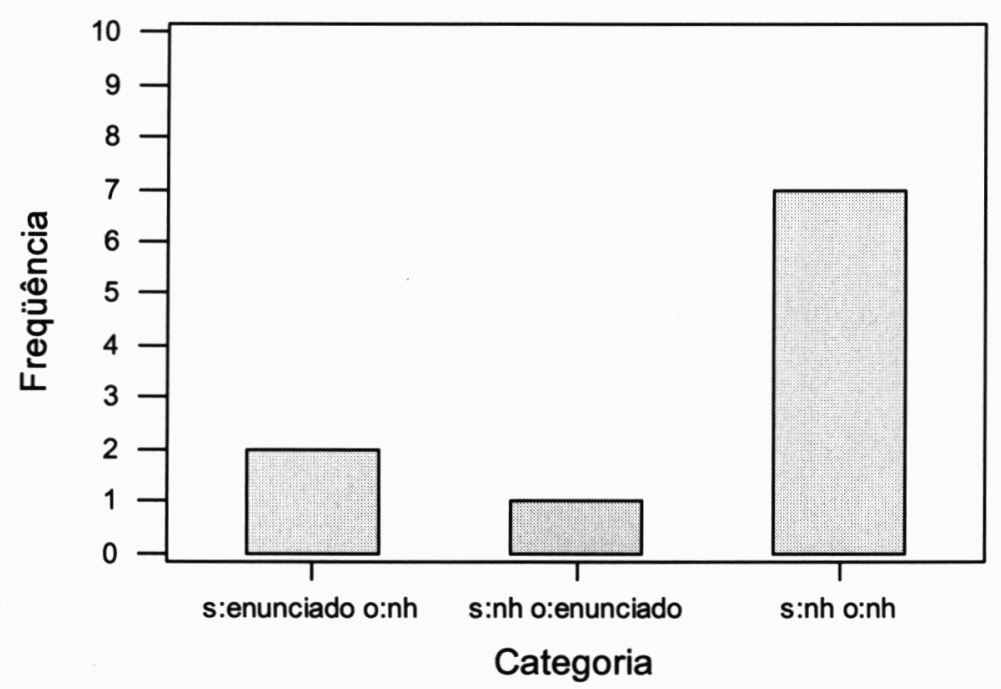

Segunda resposta - Pergunta 5

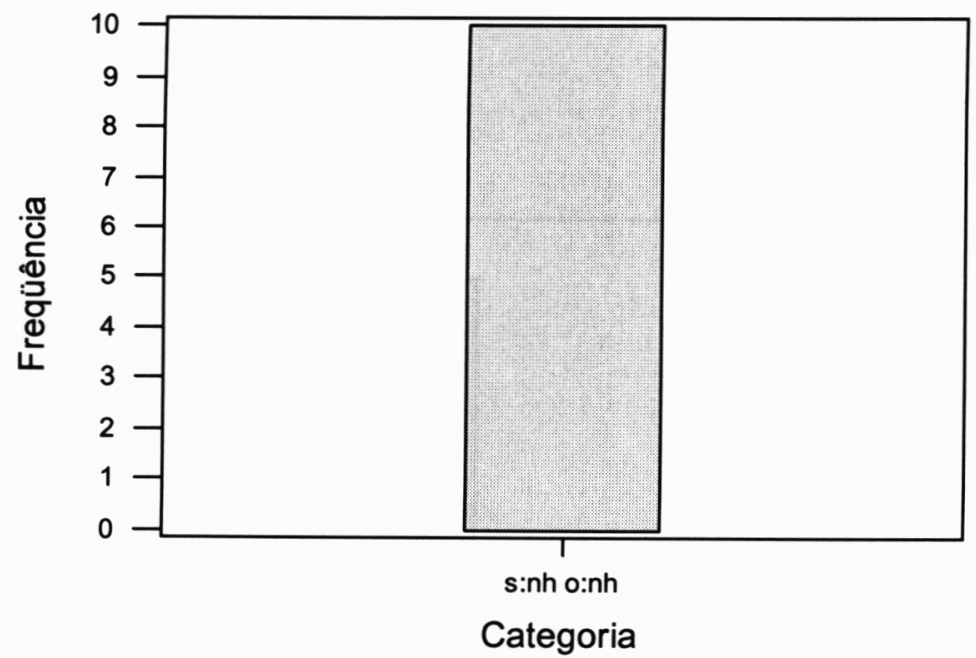

(c) Terceira resposta - Pergunta 5 
Figura 19: Gráfico das freqüências observadas de cada categoria de sugestão - observação para pertinência da pergunta 4 na primeira resposta

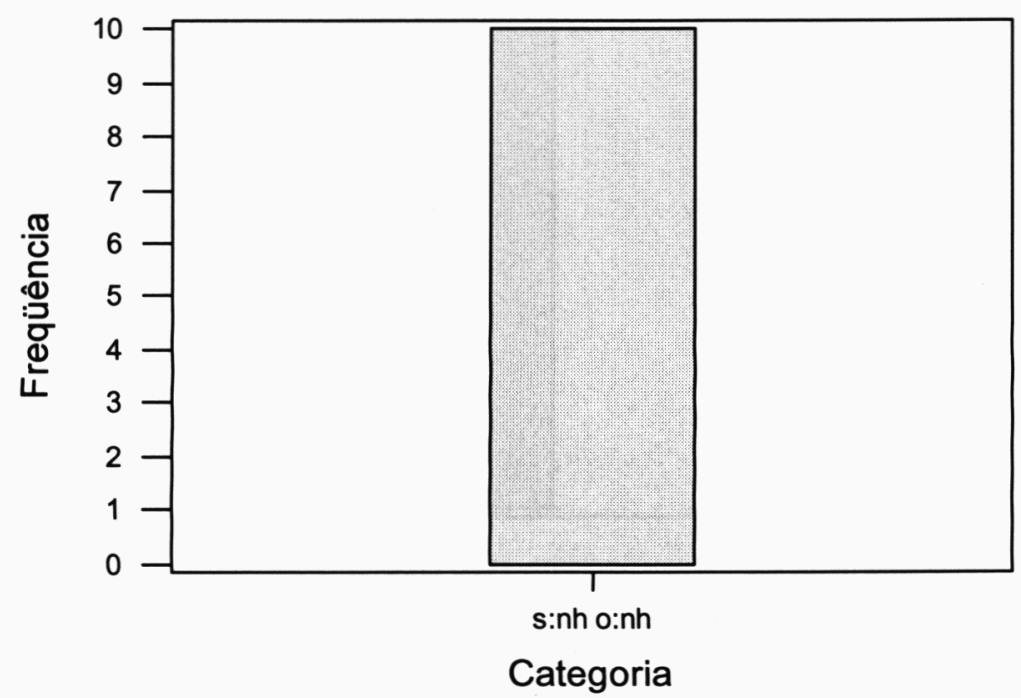

Figura 20: Gráfico das freqüências observadas de cada categoria de sugestão - observação para forma da pergunta 4 na primeira resposta e da pergunta 5 na segunda e terceira respostas

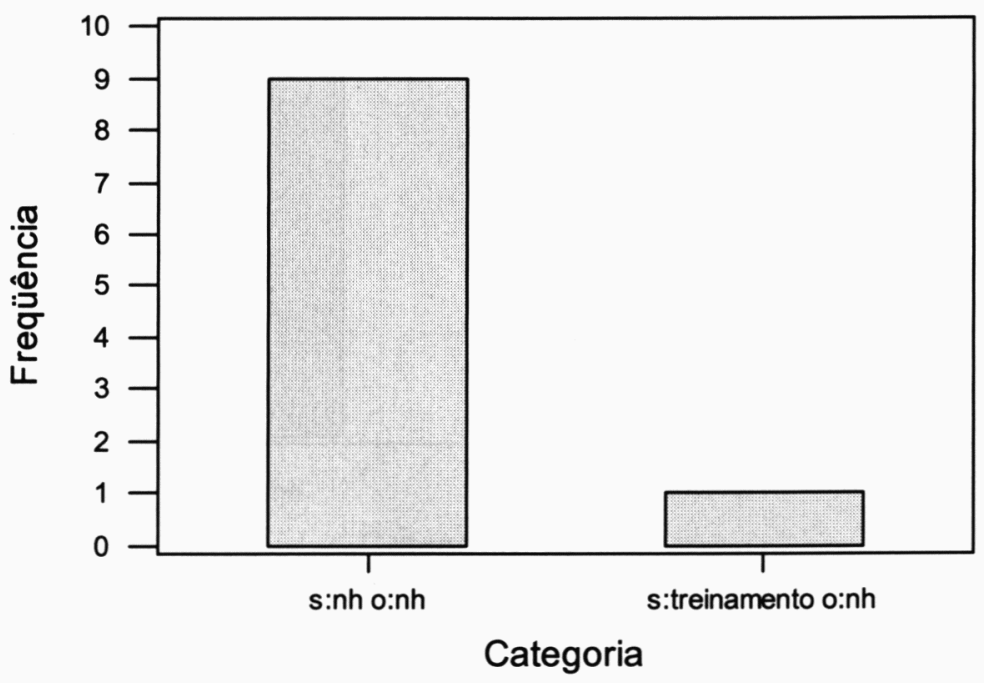

Primeira resposta - Pergunta 4 


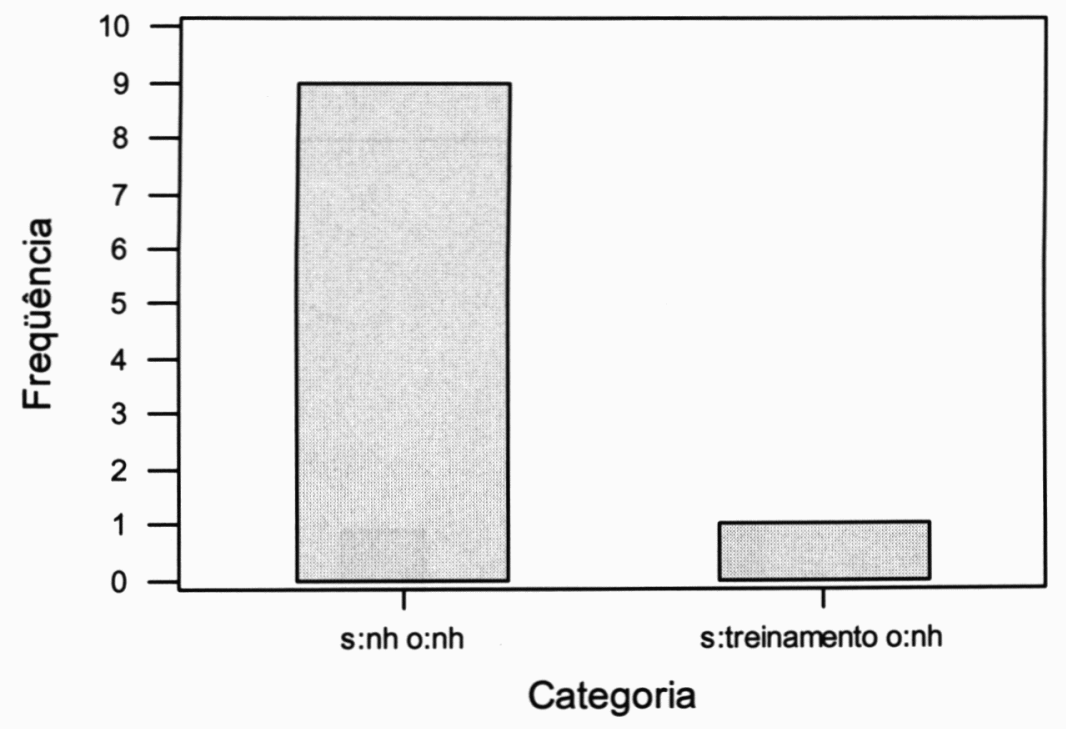

Segunda resposta - Pergunta 5

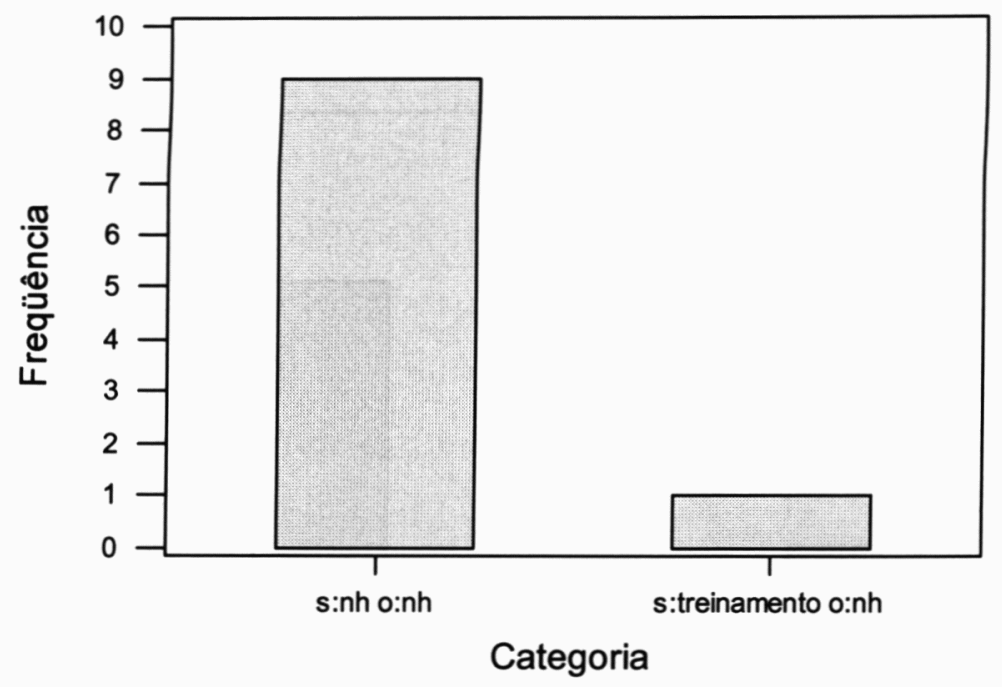

Terceira resposta - Pergunta 5 
Figura 21: Gráfico das freqüências observadas de cada categoria de sugestão - observação para a pergunta 5 da primeira resposta e pergunta 6 na segunda resposta referentes à apresentação gráfica do instrumento

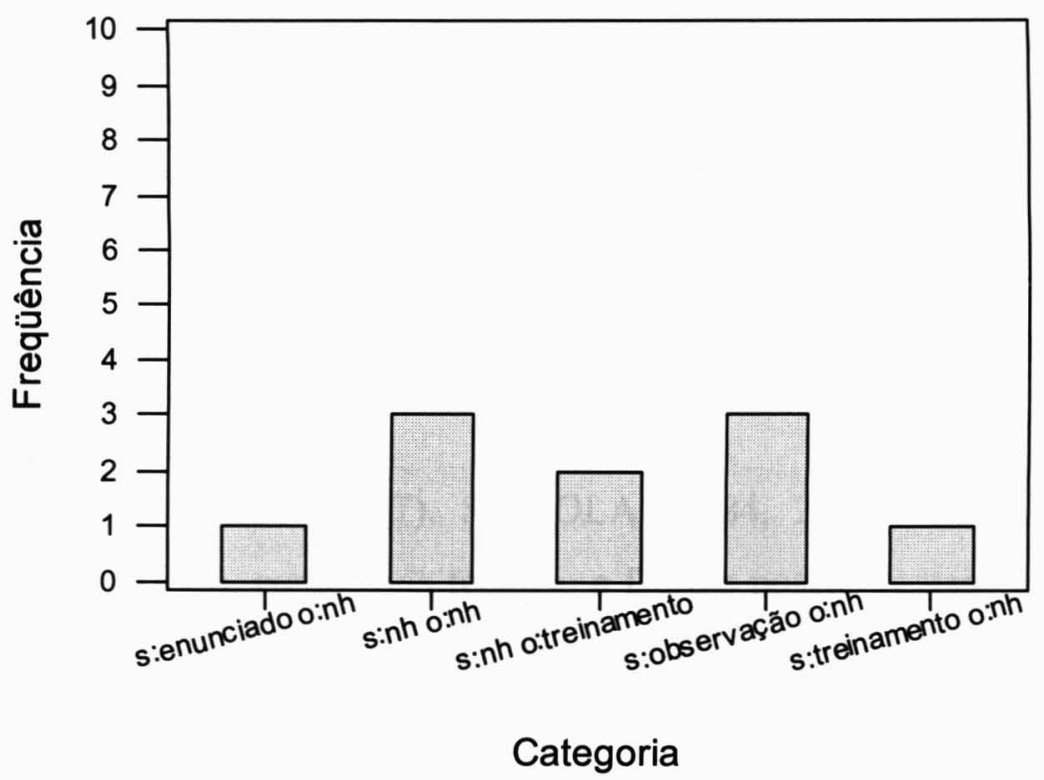

Primeira resposta - Pergunta 5

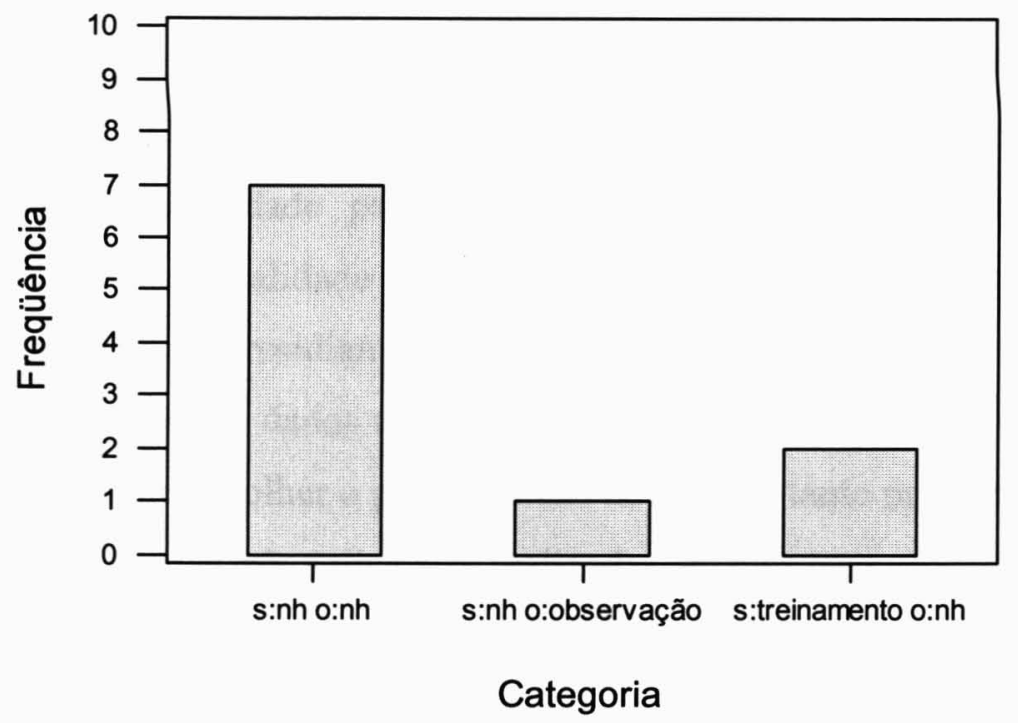

(b) Segunda resposta - Pergunta 6 


\section{DISCUSSÃO DOS RESULTADOS}

De acordo com VIEIRA (1998), a discussão dos dados deve explicar os resultados da pesquisa, sugerindo a autora que se dê resposta ao significado dos dados estatísticos apresentados. Dessa maneira, optamos por dividir este capítulo de forma a contemplá-los sob duas perspectivas: da aplicação da técnica Delfos e do consenso do MMRI.

\subsection{Discussão dos resultados, segundo a aplicação da técnica Delfos}

Segundo POLIT (1987), SPÍNOLA (1984, 2002), WILLIAMS e WEBB (1994) e GIL (1995), como toda técnica, a Delfos possui vantagens e desvantagens. Corroborando os dados da literatura, destacamos como pontos positivos em todas as fases desta pesquisa a forma de coleta de dados. SPÍNOLA (2002) destaca que a interação do grupo e a liberdade para exprimir opiniões são favorecidas por meios alternativos para sua emissão. Como essa técnica prevê uma interlocução sem a obrigatoriedade de entrevistas, ela tende a potencializar posições mais fidedignas, com uma maior reflexão sobre o tema proposto, garantindo o anonimato do juiz e deixando-o mais à vontade para que efetive seu julgamento. Além dessa vantagem, que confere maior validade ao consenso obtido, ela se torna mais ágil, barateando custos, dando liberdade para que se selecione o especialista mais adequado, independente da localidade onde este resida. No presente estudo, dos 10 juízes selecionados, 6 seis residiam em localidade diversa de onde transcorreu a pesquisa. A forma de coleta de dados utilizada foi o correio postal e eletrônico, que permitiu a cada participante escolher o período mais adequado, tanto para responder às questões do instrumento, nas três aplicações realizadas, quanto para enviá-las.

Na primeira aplicação, 6 dos 10 juízes enviaram o questionário por e-mail, à noite ou durante o final de semana. Na segunda, esse número foi superior, 7, e, finalmente, na terceira e última aplicação, novamente 6 preferiram o horário noturno para a realização desse trabalho. Percebemos por esses dados como a utilização de meios alternativos de coleta de dados são produtivos, por eles se mostrarem 
adequados às possibilidades e disponibilidades do expertise. Constatamos ainda, confirmando os dados de literatura descritos por POLIT (1987) e SPÍNOLA (1984), que a cada aplicação, após a inclusão das sugestões enviadas pelos juízes, a concordância acerca dos dados do instrumento tendia ao consenso. Tal fato é evidenciado pela análise comparativa entre a primeira, a segunda e a terceira aplicação, demonstrando o comprometimento dos juízes para com a pesquisa, o cabedal de conhecimento acerca tema e a adequação na seleção desses especialistas.

As sugestões recebidas na primeira fase de aplicação do instrumento concentraram-se mais na recomendação de se agregar questões à pergunta relativa aos dados de identificação. Quanto às relativas ao MMRI, os especialistas solicitaram que fossem formuladas de maneira mais objetiva, exemplificando as funções avaliadas em cada uma das cinco questões do instrumento.

A maior alteração efetivada no instrumento, após a aplicação da técnica Delfos, deu-se no objetivo central do MMRI. Da forma como o instrumento final foi construído, após a consolidação do consenso realizado pelas incorporações das sugestões recebidas, esse passou a identificar a freqüência dos contatos dos componentes da RSSI para com o idoso e não necessariamente a proximidade desses relacionamentos.

A diferença entre os dois conceitos reside na efetivação do contato (RAMOS M 2002). Segundo ROSENMAYR e KÖEISKEIS (1965), citados por RODRIGUES e RAUTH (2002), a "proximidade à distância" indica que pessoas distantes fisicamente podem ser consideradas presentes, próximas quanto aos aspectos afetivos do relacionamento, efetivando telefonemas ou enviando cartas, por exemplo. Já na freqüência de contatos, verificamos como essa proximidade ocorre, se efetiva. Quantificamos o aspecto presencial do contato. Dessa forma, o MMRI validado registra a freqüência de contatos, mantendo do instrumento original a associação à função desempenhada pelos seus componentes.

Constatamos, por fim, o grande interesse dos juízes na pesquisa. Não tivemos nenhuma recusa em sua participação e nenhuma desistência no transcurso das três fases de sua realização. Enfatizamos, contudo, que na terceira aplicação, nem todos os juízes enviaram a resposta no período solicitado, exigindo do pesquisador 
contatos telefônicos freqüentes. Tal fato evidencia a possível dificuldade na continuidade de um estudo em que sejam necessárias mais do que três aplicações. Concordamos, desse modo, com o expresso na literatura por SPÍNOLA e POLIT, que recomendam entre duas a três aplicações. Julgamos ser esse o número adequado, para que se evite a perda dos juízes, predispondo a um viés que comprometa a validade interna do instrumento, por se contar apenas com os juízes mais interessados (POLIT 1987; PEREIRA 1995).

Segundo POLIT (1987) e SPÍNOLA (1984, 2002), os fatores relativos à seleção dos juízes e abrangência da pesquisa, que representam aspectos de sua validade interna, e os referentes ao material analisado pelos juízes, devem ser cuidadosamente planejados e acompanhados para que não prejudiquem seu resultado, predispondo a um viés tanto relativo à validade interna do instrumento, quanto à sua validade externa.

No transcurso desta pesquisa, procuramos evitar suas desvantagens da seguinte forma:

\section{- Quanto à validade lógica}

De acordo com FLETCHER, FLETCHER e WAGNER 1989, em pesquisas com dados subjetivos, é muito comum aferir-se a validade por meio de questionários, durante uma entrevista, que se convertem em escalas de medidas. Recomendam os autores sua utilização, apesar de tal procedimento não ser tão seguro para a confirmação da validade quanto um teste clínico. Dessa forma, ressaltam não ser apropriada a utilização dos termos "válida" ou "inválida" ao nos referirmos a uma escala. Nesta mesma linha de pensamento, GIL (1996) relata que a validade lógica ou consensual é utilizada para se verificar a acurácia de instrumentos da área das ciências sociais e humanas, como, por exemplo, as escalas psicométricas. Deve, outrossim, o critério da seleção dos juízes ser bastante criterioso, para que se evite uma concordância no erro, ocasionada por um viés de seleção.

Para que tal fato não interferisse no resultado desta pesquisa, a escolha dos juízes foi sobremaneira cuidadosa, com a inclusão de especialistas das duas áreas 
envolvidas neste estudo: gerontologia e teoria sistêmica. Além disso, devido ao caráter multidisciplinar deste instrumento, característica também preponderante no âmbito da saúde pública, definimos como critério de seleção, juízes com diversas formações profissionais, conforme descrito no capítulo de metodologia.

\section{- Quanto a validade interna e externa}

Recomenda-se, segundo POLIT (1987) e SPÍNOLA (1984), para que não haja comprometimento da validade interna, o cuidado com a manutenção de todos os juízes selecionados, pois as reaplicações podem predispor os informantes a se desinteressarem pela pesquisa, fazendo com que, nas sucessivas consultas, conte-se apenas com os mais interessados. No que diz respeito à validade externa, deve-se ter o cuidado de observar se o dado encontrado pode ser generalizado ou se é válido apenas para os participantes do estudo. Procuramos evitar as desvantagens, relativas à validade interna, seguindo as recomendações das autoras acima citadas, enviando uma carta convite a cada fase das três aplicações, explicando e reiterando seu motivo e a importância da participação do especialista na pesquisa. Quanto à validade externa, essa não foi objeto do estudo, ou seja, os dados encontrados são válidos apenas para os juizes desta pesquisa. Contudo, a excelência dos especialistas que dela participaram indicam a possibilidade da generalização de seus resultados.

\section{- Quanto ao envio do material analisado pelos juizes}

Quanto ao envio do material, deve-se estar atento à possibilidade de extravio ou ser entregue de forma incompleta, dizem SPÍNOLA $(1984,2002)$, POLIT (1987) e FARO (1997). Do material expedido pelos juizes, tanto por e-mail como pelo correio postal, não se observou nenhum problema como o recebimento incompleto dos dados, sendo esta desvantagem também controlada.

\subsection{Discussão dos resultados, segundo a obtenção de consenso sobre o MMRI}

A técnica propiciou a formação de um locus de comunicação sobre um tema extremamente importante, que é o da necessidade de se dispor de técnicas capazes de 
realizar a validação de instrumentos para identificar a rede de suporte social, (MATSUKURA, MARTURANO e OISHI 2002; GRIEP, CHOR, FAERSTEIN e LOPES 2003).

A consulta a especialistas das áreas da gerontologia e da terapia sistêmica foi também bastante apropriada e adequada, pela característica do instrumento, tornando sua utilização viável em saúde pública. Quanto à participação desses especialistas, podemos dizer que a adesão de todos os juízes selecionados nas três fases de aplicação do instrumento aponta para o interesse e envolvimento desses na participação da pesquisa, corroborando o descrito por FARO (1995), que utilizou esta técnica para validar condutas de enfermagem nos indivíduos com lesão medular ALMEIDA (2003), que a utilizou para validar um instrumento para verificar a capacidade de autocuidado do idoso, e ÁVILA e SANTOS, que em 1988 a empregou numa pesquisa sobre políticas para o setor púbico. Esses autores descrevem a técnica Delfos como propícia a promover o relacionamento dos profissionais, reconhecendoos e valorizado-os por sua competência no tema proposto, estimulando a participação deles durante todo o processo.

Constatamos que a cada aplicação ocorreu um maior consenso, demonstrado por notas mais altas para cada questão, diminuindo, por conseguinte, o desvio padrão, ou seja, a dispersão das avaliações.

Quanto à questão relativa aos dados de identificação, registrada no MMRI com o número 1 , solicitamos a análise somente sobre sua clareza e pertinência, dispensando a relativa à forma de registro no MMRI, uma vez que esses dados não seriam registrados no instrumento gráfico, mas sim após cada tópico formulado.

Comparando as três aplicações, verificamos que na primeira os juízes atribuíram notas mais baixas quanto à clareza do instrumento. Na segunda, após os ajustes, esse comportamento alterou-se, com notas que culminaram em médias suficientes para a validação de todas as questões, exceto a questão de número 5 , que foi reaplicada, agregando-se as sugestões fornecidas nessa segunda aplicação.

Quanto ao item pertinência, as notas, já na primeira aplicação, mostraram-se adequadas para a obtenção do consenso, não sendo novamente aplicadas, exceto para a pergunta sobre os dados de identificação, que, apesar de já ter consenso, foi 
novamente aplicada, por havermos agregado muitos dados sugeridos pelos juízes, alterando de forma substancial a questão. Na segunda aplicação, essa questão obteve a totalidade de concordância quanto à pertinência.

Em todas as questões, na categoria de sugestões e observações, o proposto com maior freqüência referiu-se ao modo de formular as questões clareza da pergunta, categorizada como enunciado.

Para torná-las mais compreensíveis ao idoso, os juízes sugeriram a inclusão de exemplos agregados a cada questão formulada a ser registrada no MMRI. Assim sendo, após os ajustes realizados em cada uma das três aplicações, a cada pergunta que denotava uma função a ser auxiliada ou realizada pelo componente da rede de suporte social do idoso, agregaram-se exemplos, sugeridos pelos especialistas.

As outras categorias de sugestões/observações que tiveram grande expressão foram a de treinamento ao pesquisador, e necessidade de aprimorar conceitos acerca do objetivo do instrumento. As duas categorias de sugestões foram acatadas, sendo a primeira condição recomendada para que o entrevistador aplique o instrumento. Além dessa recomendação, incluímos um maior detalhamento das orientações ao entrevistador, que agregou exemplos de como as perguntas devem ser formuladas e registradas, seguido de um MMRI preenchido. Já a sugestão relativa à parte conceitual do MMRI, foi realizada tendo no arcabouço teórico desta pesquisa a conceituação de freqüência de contatos e proximidade de relacionamento, fundamento quanto aos aspectos relacionais do indivíduo, como já descrito no item 2.3.4. O conceito de proximidade de relacionamento tem uma característica eminentemente qualitativa, preponderando os aspectos afetivos que envolvem seu estabelecimento (Kahn e Antonucci, citados por NERI 2002, p. 111).

Segundo DOBROF (1997), a proximidade de relacionamento promove a intimidade à distância entre o idoso e seu círculo de relações, principalmente as familiares. Já a freqüência de contatos tem como característica primordial identificar a participação efetiva dos componentes da rede de relações, a concretização do apoio recebido (RAMOS 2002).

Quando avaliamos o comportamento dos juízes frente ao instrumento como um todo, observamos uma linearidade entre esses, com notas e sugestões 
homogêneas, apresentando pequenas discrepâncias, principalmente na primeira aplicação, fortalecendo a consistência do instrumento após as três aplicações subseqüentes, referendando, assim, as vantagens da utilização dessa técnica de validação consensual.

$\mathrm{Na}$ análise estatística, agregamos, além da média, também a mediana e o desvio padrão, procurando aprimorar o resultado da pesquisa e demonstrando suas repercussões a cada aplicação. Tal fato é ilustrado pelas figuras 7 (a) e 8 , onde a média é "puxada para baixo" por um juiz, porém, a estabilidade da questão é expressa pela sua mediana e desvio padrão.

Adotamos para essa pesquisa, portanto, o recomendado por SPÍNOLA (2002) como forma de análise dos dados, associando à estatística mais uma medida de tendência central, a mediana, e uma de dispersão, o desvio padrão, tendo, dessa maneira, um resultado mais consistente do consenso obtido.

Nossos achados, por fim, indicam que o instrumento inicial, construído com uma pergunta relativa a dados de identificação de forma sucinta e quatro perguntas concernentes à rede de suporte social do idoso a serem registradas no Mapa Mínimo de Relações, passou a conter, na sua versão final, a questão inicial de dados de identificação com informações mais detalhadas do idoso, e cinco questões a serem registradas no MMRI, decorrentes do desmembramento da pergunta de número um em duas questões.

As sugestões recebidas relativas à forma de realizar as perguntas a serem registradas no MMRI determinaram novas formas de registro das respostas, possibilitando ao instrumento identificar a freqüência de contatos, dado objetivo que possibilita o planejamento de cuidados, quando da necessidade da participação mais efetiva dos integrantes da rede de suporte social do idoso, sendo um recurso importante para aprimorar a prática dos profissionais da área da saúde e do serviço social.

A técnica foi adequadamente aplicada para que se obtivesse a validação consensual do instrumento, uma vez que para todas as questões as médias foram superiores a 3,5, ou seja, pelo menos 7 juízes deram a nota máxima de concordância (5), denotando que a convergência mínima adotada para essa pesquisa foi suplantada. 


\section{CONCLUSÕES}

O consenso entre os juízes desta pesquisa conduziu às seguintes conclusões:

- Percentual de convergência de opiniões variou entre $80 \%$ e $90 \%$ quanto à clareza, pertinência das perguntas e adequação do MMRI, sobrepujando os $70 \%$ de convergência definida para esta pesquisa.

- A associação da escala de Lickert com a apresentação de dados qualitativos possibilitou uma avaliação mais rica e aprofundada do MMRI.

- Pelo caráter multidisciplinar que permeia o MMRI, o treinamento dos profissionais é de suma importância para a sua correta aplicação, sendo um importante recurso para a prática do profissional da área social e de saúde.

- Pela competência dos juízes selecionados, o MMRI, instrumento gráfico que possibilita a identificação da rede de suporte social do idoso, pode ser considerado validado consensualmente para esses especialistas. 


\section{REFERÊNCIAS}

1. Almeida MHM. Validação do instrumento C.I.C.Ac - Classificação de idosos quanto à capacidade para o autocuidado. São Paulo; 2003. [Tese de doutorado - Faculdade de Saúde Pública da USP].

2. Ander-Egg E. Introducción al trabajo social. Buenos Aires: Lumen/Humanitas; 1996.

3. Andrade GRB, Vaitsman J. Apoio social e redes: conectando solidariedade saúde. Ciênc. Saúde Col. [on line] 2002; 7(4): 925-934. Disponível em <URL: http://www.scielo.br/scielo.php?script=sci_arttex\&pid=S1413> [2004 Jun 02]

4. Aquino FTM, Cabral BES. O idoso e a família. In: Freitas EV, Py L, NERI AL, Cançado FAX, Gorzoni ML, Rocha SM. Tratado de geriatria e gerontologia. Rio de Janeiro: Guanabara Koogan; 2002. p. 1.056-60.

5. Ávila HA, Santos MPS. A atualização e análise de políticas para o setor público. Rev Adm Publ 1988; 22(4): 17-33.

6. Ayéndez MS. El apoyo social informal. Washington (DC): Organización Panamericana de la Salud; 1994 (OPAS - Publicación Científica, 546: 360-8).

7. Brasil. Constituição da República Federativa do Brasil. São Paulo: IMESP; 1988.

8. Brasil. Estatuto do Idoso, Lei n. 10.741, de 01.10.2003. Diário Oficial da República Federativa do Brasil. Brasília; 2003.

9. Brasil. Lei n. 8.842. Dispõe sobre Política Nacional do Idoso, cria o Conselho Nacional do Idoso e dá outras providências. Diário Oficial da República Federativa do Brasil, Brasília, 3 jul 1996. Seção 1, v. 134, n. 128, p. 12.277-79.

10. Brasil. Portaria do Gabinete do Ministro de Estado da Saúde de n. 1395, de 9 de dezembro de 1999. Aprova a Política Nacional de Saúde do Idoso e dá outras providências. Diário Oficial da República Federativa do Brasil, Brasília, 13 de dez 1999. Seção 1, n. 237-E, p. 21. 
11. Brasil. Portaria do Gabinete do Ministro de Estado da Saúde, n. 702. Cria mecanismos para a organização e implantação de Redes Estaduais de Assistência à Saúde do Idoso. Diário Oficial da República Federativa do Brasil, Brasília, 12 abr. 2002-a.

12. Brasil. Portaria da Secretaria de Assistência à Saúde do Ministério da Saúde de n. 249, de 12 de abril de 2002. Aprova, na forma de Anexo I desta portaria, as normas para Cadastramento de Centros de Referência em assistência à Saúde do Idoso. Diário Oficial da República Federativa do Brasil, Brasília, 12 abr. 2002-b.

13. Bowling A. Measuring health: a review of quality of life measurements scales. Baltimore: Open University Press; 1997. Measuring social network and social support.

14. Caldas CP. Envelhecimento com dependência: responsabilidade e demandas da família. Cad Saúde Pública 2003; 19(3): 773-81.

15. Camarano AA, Ghauori E, Kanso S. Famílias com idosos: são ninhos vazios. Texto para discussão 950. Instituto de Pesquisa Econômica Aplicada [on line] 2003. Disponível em <URL: http://ssm.com/abstrat=432720>.

16. Camarano AA. Envelhecimento da população brasileira: uma contribuição demográfica In: Freitas EV, Py L, NERI AL, Cançado FAX, Gorzoni ML, Rocha SM. Tratado de geriatria e gerontologia. Rio de Janeiro: Guanabara Koogan; 2002. p. 58-70.

17. Carter B, McGoldrick M. As mudanças no ciclo de vida familiar - uma estrutura para a terapia familiar. In: Carter B, McGoldrick M, organizador. As mudanças no ciclo de vida familiar. Porto Alegre: Artes Médicas; 1995. p. 8-27.

18. Carvalho JAM, Garcia RA. O envelhecimento da população brasileira: um enfoque demográfico. Cad Saúde Pública 2003; 19(3): 725-33.

19. Carstensen LL. Motivação para o contato social ao longo da vida: uma teoria de seletividade socioemocional. In: NERI AL, organizador. Psicologia do envelhecimento. Campinas: Papirus; 1995. p. 111-44. 
20. Chaimowicz F. Os idosos brasileiros no século XXI. Belo Horizonte: Postgraduate; 1998.

21. Costa MFFL, Guerra HL, Barreto SM, Guimarães RM. Diagnóstico da situação de saúde da população idosa brasileira: um estudo da mortalidade e das internações hospitalares públicas. Inf Epidemiol SUS 2000; 9(1): 23-41.

22. Dabas EN. Red de redes: las practicas de la intervencion en redes sociales. Buenos Aires: Paidos; 1993.

23. Dabas EN, Najmanovich D. Redes, el lenguage de los vínculos. Buenos Aires: Paidos; 1995.

24. Dobrof R. Sistemas de suporte social. In: Calkins E, Ford BA, Kartz P. Geriatria prática. Porto Alegre: Revinter; 1997. p. 53-60.

25. Domingues MA. Mapa mínimo de relações: adaptação de um instrumento gráfico para a configuração da rede de suporte social do idoso. São Paulo; 2000. [Dissertação de mestrado - Faculdade de Saúde Pública da USP].

26. Duarte YA. Família: rede de suporte ou fator estressor. A ótica de idosos e cuidadores familiares. São Paulo; 2001. [Tese de doutorado - Escola de Enfermagem da USP].

27. Due P, Holstein B, Lund R, Modvig J, Avlund K. Social relations: network, support and relational strain. Soc Sci Med 1999; 48: 661-73.

28. Erbolato RMPL. Relações sociais na velhice In: Freitas EV, Py L, NERI AL, Cançado FAX, Gorzoni ML, Rocha SM. Tratado de geriatria e gerontologia. Rio de Janeiro: Guanabara Koogan; 2002. p. 957-64.

29. Faro ACM. Do diagnóstico à conduta de enfermagem: a trajetória do cuidar na reabilitação do lesado medular. São Paulo; 1997. [Tese de doutorado Escola de Enfermagem da USP].

30. Fletcher RH, Fletcher SW, Wagner EH. Epidemiologia clínica: bases científicas da conduta médica. $2^{\text {a }}$ ed. Porto Alegre: Artes Médicas; 1989.

31. Garcia Pintos CC. A família e a terceira idade: orientações psicogerontológicas. São Paulo: Paulinas; 1997. 
32. Gil AC. Métodos e técnicas de pesquisa social. São Paulo: Atlas; 1995.

33. Goldani AM. Arranjos familiares no Brasil dos anos 90: proteção e vulnerabilidade. Como vai a pop bras $1998 ; 3: 14-23$.

34. Gonzalez TBD, Espin GB, Andrade AME, Vea-Bayorre H. Caracterización de las relaciones familiares del anciano. Rev Cub Med Gen Integr 2001; 17(5): 418-22.

35. Griep RH, Dóra C, Faerstein E, Lopes C. Apoio social: confiabilidade test-retest de escala no Estudo Pró-Saúde. Rev Saúde Pública. [on line] 2003; 37(3): 379385. Disponível em <URL: http://www.scielo.br/scielo.php?script=sci_arttex \&pid=S0034> [2004 jun. 02].

36. Guttmann D. Logoterapia para profesionales: trabajo social significativo. Bilbao: Desclée Brouwer-Biblioteca de Psicologia; 1998.

37. Herr $\mathrm{J}$, Weakland $\mathrm{J}$. Terapia interaccional y tercera edad: asesorando a la familia del geronte. Buenos Aires: Nadir; 1979.

38. Jacob Filho W. Promoção da saúde do idoso: um desafio interdisciplinar In: Jacob Filho W, Carvalho Filho ET. Promoção da saúde do idoso. São Paulo: Lemos Editoriais; 1998. p. 11-8.

39. Karsch U. Idosos dependentes: famílias e cuidadores. Cad Saúde Pública 2003; 19(3): 861-66.

40. Karsch U, organizador. Envelhecimento com dependência: revelando cuidadores. São Paulo: EDUC; 1998.

41. Lemos N, Medeiros SL. Suporte social ao idoso dependente. In: Freitas EV, Py L, NERI AL, Cançado FAX, Gorzoni ML, Rocha SM. Tratado de geriatria e gerontologia. Rio de Janeiro: Guanabara Koogan; 2002. p. 892-97.

42. Lin N, Ensel WM, Simione RS, Kuo W. Social support stressful life events and illness: a model and empirical test. J Health Soc. Behav 1979; 20: 108-19.

43 Ludwig B. Predizendo o futuro: você considerou usar a metodologia de Delphi? J Ext. [on line] 1997; 35(5). Disponível em <URL:hppt:/www.joe.org/index.html> [2004 Out 22]. 
44. Martinelli ML. Pesquisa Qualitativa: um instigante desafio. São Paulo: Veras; 1999.

45. Matsukura TS, Marturano EM, Oishi J. O questionário de suporte social (SSQ): estudos da adaptação para o português. Rev Lat Am Enf. [on line] 2002; 10(5): 675-681. Disponível em <URL:http://www.scielo.br/scielo> [2004 Jun. 02].

46. McDowell I, Newell C. Measuring health: a guide to rate scales and questionnaires. Oxford: Oxford University Press; 1996.

47. Ministério da Saúde. Redes Estaduais de Atenção à Saúde do Idoso: guia operacional e portarias relacionadas. Brasília; 2002.

48. Moreno JL. Fundamentos de la sociometria. Buenos Aires: Paidos; 1967.

49. NERI AL. Palavras-chave em Gerontologia. Campinas: Alínea; 2001.

50. Neugarten BL. Dynamics of transition of middle age to old age: adaptation and life cycle. J Geriatr-psychiatry 1970; 4(1): 71-100.

51. Norbeck JS, Lindsey AM, Carrieri VL. The development of an instrument to measure social support. Nurs Res 1981; (30): 264-9.

52. Organização Mundial de Saúde. Saúde dos Idosos; Envelhecimento e Saúde: Um Novo Paradigma. In: Anais da $25^{\mathbf{a}}$ Conferência Sanitária: 50 $^{\mathbf{a}}$ Sessão do Comitê Regional; 1998 set 21-25; Washington (DC): Organização Panamericana de Saúde; 1998.

53. Organização Mundial de Saúde. Paradigmas da Atenção ao Idoso. Anais da 26$^{\text {a Conferência Sanitária: 54 }}{ }^{\mathrm{a}}$ Sessão do Comitê Regional. 2002 set; Washington (DC): Organização Pan-americana de Saúde; 2002.

54. Papaléo Neto M. O estudo da velhice no século XX: histórico, definição do campo e termos básicos. In: Freitas EV, Py L, NERI AL, Cançado FAX, Gorzoni ML, Rocha SM. Tratado de geriatria e gerontologia. Rio de Janeiro: Guanabara Koogan; 2002. p. 91-9.

55. Paschoal SMP. Epidemiologia do envelhecimento. In: Papaleo Neto M. Gerontologia. São Paulo: Atheneu; 1996. p. 313-23. 
56. Paschoal, SMP. Qualidade de vida na velhice. In: Freitas EV, Py L, NERI AL, Cançado FAX, Gorzoni ML, Rocha SM. Tratado de geriatria e gerontologia. Rio de Janeiro: Guanabara Koogan; 2002. p. 79-84.

57. Pereira, MG. Epidemiologia teoria e prática. Rio de Janeiro: Guanabara Koogan; 1995.

58 Perracini M, Najas M, Bilton T. Conceitos e princípios em reabilitação gerontológica. In: Freitas EV, Py L, NERI AL, Cançado FAX, Gorzoni ML, Rocha SM. Tratado de geriatria e gerontologia. Rio de Janeiro: Guanabara Koogan; 2002. p. 814-19.

59.Piola SF; Vianna SM; Vivas-Consuelo D. Estudo Delphi: atores sociais e tendências do sistema de saúde brasileiro. Cad Saúde Pública 2002; (18): 98115.

60. Polit DF. Nursing research: principles and methods. $3^{\mathrm{a}}$ ed. Philadelphia: JB Lippincott Company; 1987.

61. Ramos LR et al. Perfil do idoso em área metropolitana na região sudeste do Brasil: resultados de inquérito domiciliar. Rev Saúde Pública 1993; (27): 87-94.

62. Ramos LR. Epidemiologia do envelhecimento. In: Freitas EV, Py L, NERI AL, Cançado FAX, Gorzoni ML, Rocha SM. Tratado de geriatria e gerontologia. Rio de Janeiro: Guanabara Koogan; 2002. p. 72-8.

63. Ramos MP. Apoio Social e saúde entre idosos. Sociologias. [on line] 2002; (7): 156-175. Disponível em <URL: http://www.scielo.br/scielo.php?script=sciarttex\&pid=S1517> [2004 Jun 02]

64. Rapizo R. Terapia Sistêmica de Família: da instrução à construção. Rio de Janeiro: Instituto NOOS; 1998.

65. Rodrigues NC, Rauth J. Os desafios do envelhecimento no Brasil. In: Freitas EV, Py L, NERI AL, Cançado FAX, Gorzoni ML, Rocha SM. Tratado de geriatria e gerontologia. Rio de Janeiro: Guanabara Koogan; 2002. p. 106-10. 
66. Roles L, Curiel GR, Garcia LMC, Coles LC, Medrano MSG, Gonzalez MS. Redes y apoio social en ancianos enfermos de escasos recursos en Guadalajara, México. Cad Saúde Pública 2000; 16(2): 557-60.

67. Saad PM. Arranjos domiciliares e transferências de apoio informal. In: Lebrão ML, Duarte Y. O projeto sabe no município de São Paulo: uma abordagem inicial. Brasília: Organização Pan-Americana da Saúde; 2003. p. 201-24.

68. Salvarezza L. Psicogeriatria teoria y clínica. Buenos Aires: Paidos; 1996.

69. Saranson IM, Basham B, Saranson BR. Assessing social support: the social support questionaire. J Pers and Soc Psychol 1983; (44): 127-39.

70. Sayeg MA, Mesquita RAV. Políticas públicas de saúde para o envelhecimento. In: Freitas EV, Py L, NERI AL, Cançado FAX, Gorzoni ML, Rocha SM.

Tratado de geriatria e gerontologia. Rio de Janeiro: Guanabara Koogan; 2002. p. 1083-89.

71. Seixas MR. Sociodrama familiar sistêmico. $2^{a}$ ed. São Paulo: Aleph; 1992.

72. Shanas E. The family as a social support system in old age. Gerontologist 1979; (19): 169-74.

73. Sluzki CE. A rede social na prática sistêmica: alternativas Terapêuticas. São Paulo: Casa do Psicólogo; 1997.

74. Sluzki C. La rede social en la vejez: disquisiciones clínicas y conceptuales a partir de una consulta. Anais do III Congresso Brasileiro de Terapia Familiar y I Encuentro Latino Americano. Rio de Janeiro; 1998.

75. Sluzki C. The extinction of the galaxy: social networks in the erderly patient. Family Process. 2000; (39): 271-84.

76. Spínola AWP. Delphos: proposta tecnológica alternativa. São Paulo: Universidade de São Paulo. Faculdade de Saúde Pública; 1984.

77. Spínola AWP. Técnica Prospectiva Delphi: abordagem teórico-prática. São Paulo; 2002. [Apostila do Curso de Mestrado Interinstitucional - FSP-USPFAESA - Universidade de São Paulo - Faculdade de Saúde Pública]. 
78. Woundenberg, F. An evaluation of delphi tecnological. Forecasting and Social Change 1991; 40: 131-50.

79. Veras RP. País jovem com cabelos brancos: a saúde dos idosos no Brasil. $2^{\mathrm{a}}$ ed. Rio de Janeiro: Relume-Dumará; 1994.

80. Vieira S. Introdução à bioestatística. Rio de Janeiro: Campus; 1991.

81. Vieira S. Como escrever uma tese. $2^{a}$ ed. São Paulo: Pioneira; 1998.

82. Villela W, Kalckmann S, Pesoto UC. Investigar para o SUS: construindo linhas de pesquisa. Temas de Saúde Coletiva 2002; (2): 113-7.

83. Williams PL, Webb C. The Delphi tecnique: a methodological discussion. J Adv Nurs 1994; 19(1): 180-6. 
ANEXO 1

\section{AUTORIZAÇÃO DO AUTOR PARA ADAPTAÇÃO DO MAPA MÍNIMO DE RELAÇÕES}

Ilmo. Professor Carlos Sluzki

Diretor do Serviço de Psiquiatria do

Santa Barbara Cottage Hospital

Santa Barbara - Califórnia

E-mail: csluzki@sbch.org

Prezado Professor

Sou aluna do Curso de Mestrado da Faculdade de Saúde Pública da Universidade de São Paulo - Brasil. Estou pesquisando o assunto de Rede de Suporte Social e como irei desenvolver minha tese com uma população de idosos, gostaria de sua autorização para utilizar o instrumento criado pelo senhor, o Mapa Mínimo de Relações, adaptando-o a esta população.

Atenciosamente,

\section{Marisa Accioly Domingues}

$15 / 07 / 2000$

\section{Resposta:}

Date: Tue, 03 aug 1999 11:30: 11.

From: Carlos Sluzki, M.D. <csluzki@cottagehealthsystem.org>

To: marisaccioly@zipmail@.com.br

Estimada colega:

Com todo gusto le autorizo a que utilice y cite los modelos desarrolados en mi libro sobre Rede de Suporte Social.

Cordialmente,

Carlos Sluzki

P.S. Si me envia por e-mail su direccion postal, le eniare algunas ideas adicionales sobre o tema. 
ANEXO 2

PARECER DO COMITÊ DE ÉTICA EM PESQUISA DA FACULDADE DE SAÚDE PÚBLICA DA UNIVERSIDADE DE SÃO PAULO - COEP 


\section{Universidade de São Paulo \\ Faculdade de Saúde Pública \\ COMITE DE ETICA-COEP}

Av. Dr. Amaldo; 715 - CEP $01246-904$ - Săo Paulo - Brasil

Telefones: (55-11) 3066-7734 - fone/fax (55-11)3064-7314-e-mail:mdgracas@usp.br

\section{.COEP/84/03}

20 de maio de 2003

Pelo presente, informo que o Comitê de Ética em Pesquisa da cculdade de Saúde Pública da Universidade de São Paulo-COEP, analisou e rovou, em sua $4^{*} .103$, realizada em 13.05.03, de acordo com os requisitos da esolução CNS/196/96, o Protocolo de Pesquisa n. ${ }^{\circ}$ 964, intitulado: "REDEE DE UPORTE 'SOCIAL DO IDOSO: VALIDAÇÃO DE UM MAPA MÍNIMO DE ELAÇÕES", apresentado pela pesquisadora Marisa Accioly Rodrigues da Costa 'omingues.

Atenciosamente,

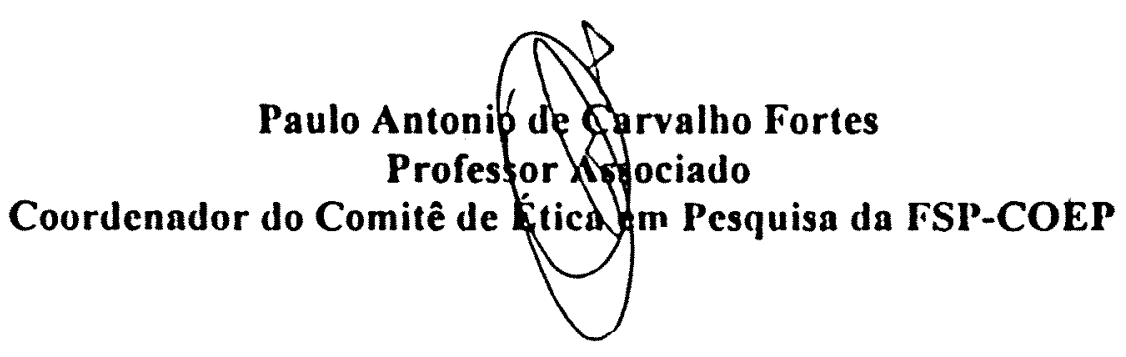




\section{ANEXO 3 \\ CARTA CONVITE PRÉ-TESTE}

Prezado (a) Colega.

A permanência do idoso na comunidade, desenvolvendo suas atividades cotidianas e exercendo sua cidadania, é a diretriz precípua da Política Nacional do Idoso. Em algumas circunstâncias, contudo, ele pode vir a requisitar o auxílio das pessoas do seu rol de relacionamentos. Segundo Néri (2001) e Sluzki (1997), este conjunto de indivíduos é denominado de Rede de Suporte Social.

A identificação dessa rede de relações é, portanto, de extrema importância para que possamos dar-lhe visibilidade, valorizando-a e mobilizando-a, efetivando dessa maneira a parceria entre o apoio informal, provindo desses relacionamentos, e o formal, constituído pelos profissionais que atuam com o idoso.

Sendo assim, gostaria de contar com a sua colaboração como um juiz para o préteste dessa pesquisa. Sua participação implica avaliar um instrumento para identificar a Rede de Suporte de Relações do Idoso que pretendo validar.

\section{Sobre o Mapa Mínimo de Relações}

O Mapa Mínimo de Relações foi formulado por Carlos Sluzki, médico psiquiatra, argentino, radicado nos Estados Unidos. Ele dirige uma instituição para doentes mentais na Califórnia e trabalha com um enfoque de teoria e terapia sistêmica, formulando esse instrumento para utilização com essa clientela. Cabe ainda esclarecer que o instrumento original não é validado no idioma em que foi concebido, o espanhol, e que sua tradução para o português deu-se por meio de um livro publicado em 1997, com a anuência do autor.

Com a permissão do Professor Sluzki, em minha dissertação de mestrado, também na Faculdade de Saúde Pública da USP, em 2000, adaptei o instrumento para a utilização com idosos.

Neste estudo pretendo validar o MMRI para a avaliação da rede de suporte social dos idosos em nosso meio sociocultural, verificando também sua confiabilidade.

\section{Sobre o método de validação a ser utilizado}

Para a validação de conteúdo do MMRI utilizarei a técnica Delfos, que busca o consenso sobre questões formuladas em um dado instrumento (Spínola 1984). Tal consenso é obtido submetendo o instrumento à análise de especialistas, denominados de "juízes".

\section{Sobre as etapas da pesquisa}

Enviarei o instrumento ao senhor(a) simultaneamente por meio eletrônico e pelo correio, com envelope já selado para a resposta, sendo o prazo para devolução em ambos os casos de 10 dias.

A partir do recebimento do instrumento com seu julgamento, elaborarei um novo questionário com as questões consensuais. Considerarei consenso o índice $70 \%$ ou mais de aprovação para cada questão.

O novo questionário produzido será então novamente enviado, e nele explicitarei as médias obtidas em cada questão e a sua posição frente a cada pergunta. 
O Instrumento que Ihe enviarei compõe-se de:

- 4 (quatro) perguntas relativas à identificação do pesquisado;

- 4 (quatro) perguntas acerca das funções desempenhadas pelos integrantes da Rede de Suporte Social do Idoso;

- 1 (uma) pergunta quanto à apresentação gráfica do instrumento;

- Mapa Mínimo de Relações, onde as respostas deverão ser registradas;

- instrutivo para o registro das respostas no MMRI.

Conto com sua participação para que tenhamos um instrumento que possa ser utilizado por profissionais da área da gerontologia, otimizando nossa avaliação e intervenção.

Antecipadamente agradeço sua valiosa colaboração, colocando-me à disposição para outros esclarecimentos que se façam necessários.

Atenciosamente,

\section{Marisa Accioly Domingues}

Aluna de Pós-Graduação, nível doutorado, da Faculdade de Saúde Pública da USP Assistente Social, CRESS N. 13.584 Fone: (0xx11) 9219-3501

(0x×11) 3022-6897 


\section{ANEXO 4 \\ INSTRUMENTO DE COLETA DE DADOS: PRÉ-TESTE \\ MAPA MÍNIMO DE RELAÇõES DO IDOSO (MMRI)}

1) DADOS DE IDENTIFICAÇÃO

Data da entrevista: .........../.......... ..........

Nome:

Idade:

Endereço:

Fone:

2) MMRI

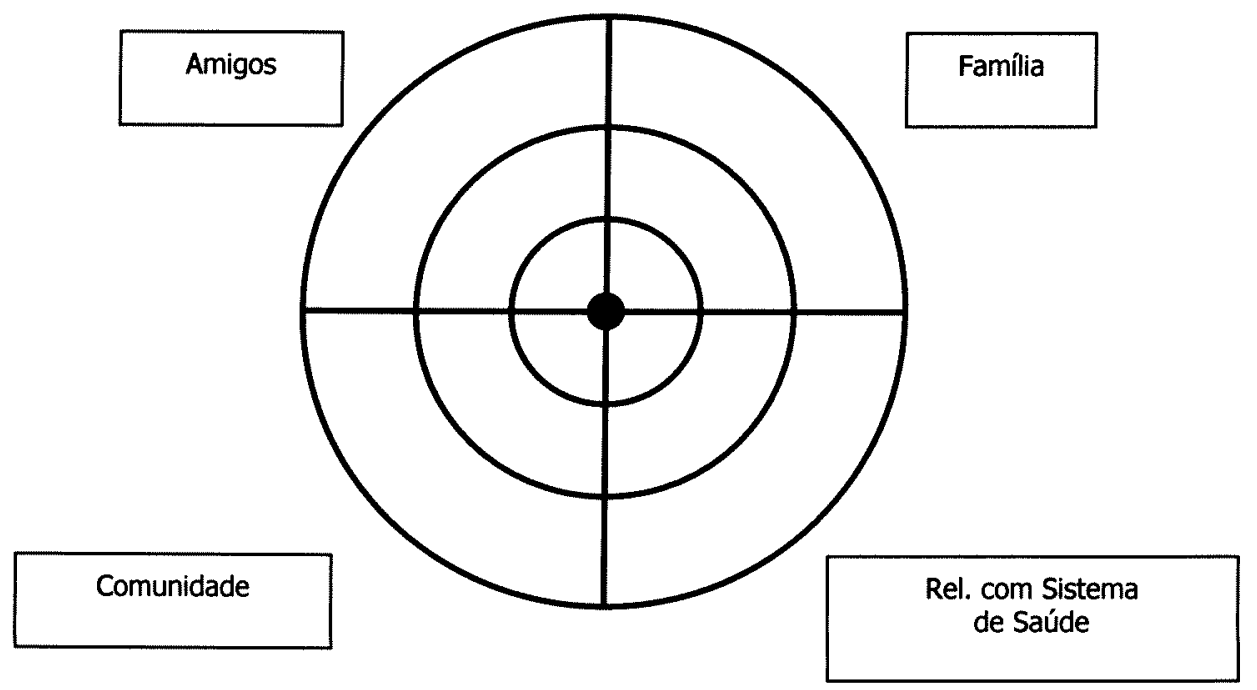




\section{INSTRUÇõES}

Formulam-se ao pesquisado, identificado pelo círculo escuro no centro no Mapa Mínimo, as seguintes perguntas:

1) Quem o(a) visita ou the faz companhia?

2) Se o(a) senhor(a) precisar de ajuda para serviços em sua casa, quem o(a) auxiliaria?

3) Se o(a) senhor(a) precisar de alguém para auxiliá-lo(a) em cuidados pessoais, quem o(a) auxiliaria?

4) Se o(a) senhor(a) precisar de auxílio financeiro, a quem o(a) senhor(a) recorreria?

Explica-se ao pesquisado, antes do início da entrevista, que cada pergunta conta com três possibilidades de respostas, correspondendo cada uma delas a uma proximidade de relacionamento. Deve-se ainda esclarecer que, se existir mais de uma pessoa com a mesma proximidade, ele deve mencioná-la agregando a conjunção "e".

O registro das respostas será realizado da seguinte forma: pelo número da pergunta formulada $\mathrm{e}$ a sigla correspondente aos quadrantes relativos à "família" e à "comunidade". Nos quadrantes relativos a amigos e relações com sistema de saúde, registra-se a resposta também pelo número da pergunta $\mathrm{e}$ um ponto • , que significa uma pessoa mencionada.

A pausa realizada entre uma pessoa citada e outra significa a inclusão da última, em um círculo mais distante. Dessa maneira, as respostas serão assim registradas:

$>$ a primeira resposta, maior proximidade de relacionamento, correspondendo ao círculo interno;

> a segunda significa relação intermediária, correspondendo ao círculo intermediário;

$>$ a terceira relação distante, sendo registrada no círculo externo.

Exemplo:

Pergunta que identifica a função de número 1) Quem Ihe faz companhia?

Resposta: minha filha e meu irmão, pausa, minha vizinha, pausa, minha amiga.

Registro no Mapa Mínimo: no primeiro círculo, registra-se o número 1 e ao lado as siglas fa $\mathrm{e}$ io (abreviação de filha e irmão).

No segundo círculo, registra-se no quadrante de relações com a comunidade o número 1 e a abreviação vi (abreviação de vizinho).

No terceiro circulo registra-se no quadrante de relações com amigos o número 1 e •

Assim procedemos com as demais perguntas.

O tamanho da Rede de suporte social corresponde, dessa maneira, ao número de registros no Mapa mínimo de relações, segundo a percepção do idoso, Além do tamanho esse instrumento nos permite conhecer a média e a amplitude dos relacionamentos por quadrante, ou seja, (composição), por círculo (proximidade de relacionamento) e por função.

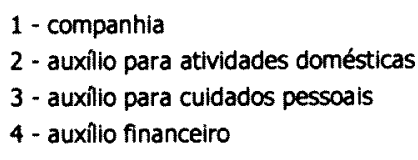

$1^{\text {a }}$ Resposta $=1^{\circ}$ Círculo $\supset$ Relacionamento Próximo

$2^{\mathrm{a}}$ Resposta $=2^{\circ}$ Círculo $\curvearrowright$ Relacionamento Intermediário

$3^{\mathrm{a}}$ Resposta $=3^{\circ}$ Círculo $\curvearrowright$ Relacionamento Distante 
REGISTRO DAS RESPOSTAS

\begin{tabular}{lll}
\hline $\begin{array}{c}\text { Amigos e Sistema } \\
\text { de Saúde }\end{array}$ & Família & Comunidade \\
\hline$\bullet$ & eo - esposo & $\mathrm{cc}$ - membros de centro de convivência \\
& ea - esposa & $\mathrm{cl}$ - membros de clubes de lazer ou serviço \\
& fa - filha & $\mathrm{gr}$ - membros de grupos religiosos \\
& fo - filho & gt - membros de grupos de terceira idade \\
& io - irmão & ps - prestadores de serviços \\
& ia - irmã & vi - vizinhos \\
& na - neta & o- outros \\
no - neto & \\
0 - outros & \\
\hline
\end{tabular}

\section{QUESTIONÁRIO DELFOS}

As perguntas relativas aos dados de identificação estão apresentadas de forma bastante sucinta.

Com relação à sua clareza, dê uma nota de 1 a 5 : (1 - total discordância; 5 - total concordância). Resposta: Nota:

Sugestões:

Observações:

Com relação à pertinência das perguntas, dê uma nota de 1 a 5: (1 - total discordância; 5 - total concordância)

Resposta: Nota:

Sugestões:

Observações: 


\section{PERGUNTAS RELATIVAS AO MMRI}

1) QUEM O(A) VISITA OU LHE FAZ COMPANHIA?

Com esta pergunta procuramos identificar as pessoas que o idoso inclui no seu círculo de relações

Com relação à clareza do enunciado, dê uma nota de 1 a 5: (1 - total discordância; 5 - total concordância)

Resposta: Nota:

Sugestões:

Observações:

Com relação à pertinência da pergunta, dê uma nota de 1 a 5 : (1 - total discordância; 5 - total concordância)

Resposta: Nota:

Sugestões:

Observações:

Com relação à forma de registro da resposta no Mapa Mínimo, dê uma nota de 1 a 5: (1 - total discordância; 5 - total concordância)

Resposta: Nota:

Sugestões: 
Observações:

2) SE O(A) SENHOR(A) PRECISAR DE AUXÍLIO PARA SERVIÇOS DOMÉSTICOS, QUEM O(A) AUXILIARIA?

Com esta pergunta procuramos identificar as pessoas que o idoso inclui no seu círculo de relações e que podem auxiliá-lo nas tarefas domésticas como: arrumar a casa, lavar a louça e até mesmo fazer as compras.

Com relação à clareza do enunciado, dê uma nota de 1 a 5 : (1 - total discordância; 5 - total concordância)

Resposta: Nota:

Sugestões:

Observações:

Com relação à pertinência da pergunta, dê uma nota de 1 a 5 : (1 - total discordância; 5 - total concordância)

Resposta: Nota:

Sugestões:

Observações:

Com relação à forma de registro da resposta no Mapa Mínimo, dê uma nota de 1 a 5: (1 - total discordância; 5 - total concordância)

Resposta: Nota: 
Sugestões:

Observações:

3) SE O(A) SENHOR(A) PRECISAR DE AUXÍLIO PARA CUIDADOS PESSOAIS, QUEM O(A) AUXILIARIA?

Com esta pergunta procuramos identificar as pessoas que o idoso inclui no seu círculo de relações, disponíveis para auxiliá-lo nos cuidados pessoais tais como: higiene, alimentação e outros.

Com relação à clareza do enunciado, dê uma nota de 1 a 5 : (1 - total discordância; 5 - total concordância)

Resposta: Nota:

Sugestões:

\section{Observações:}

Com relação à pertinência da pergunta, dê uma nota de 1 a 5: (1 - total discordância; 5 - total concordância)

Resposta: Nota:

Sugestões: 
Observações:

Com relação à forma de registro da resposta no Mapa Mínimo, dê uma nota de 1 a 5: (1 - total discordância; 5 - total concordância)

Resposta: Nota:

Sugestões:

Observações:

4) SE O(A) SENHOR(A) PRECISAR DE AUXÍLO FINANCEIRO QUEM O(A) AUXILIARIA?

Com esta pergunta procuramos identificar as pessoas do círculo de relações do idoso, que estão disponiveis e possuem condições de auxiliá-lo financeiramente.

Com relação à clareza do enunciado, dê uma nota de 1 a $5:(1$ - total discordância; 5 - total concordância)

Resposta: Nota:

Sugestões:

Observações:

Com relação à pertinência da pergunta, dê uma nota de 1 a 5: (1 - total discordância; 5 - total concordância)

Resposta: Nota:

DiDHoteCaliti 
Sugestões:

Observações:

Com relação à forma de registro da resposta no Mapa Mínimo, dê uma nota de 1 a 5: (1 - total discordância; 5 - total concordância)

Resposta: Nota:

Sugestões:

Observações:

5) QUANTO À APRESENTAÇÃO GRÁFICA DO INSTRUMENTO, DÊ UMA NOTA DE 1 A 5.

Com esta pergunta procuramos saber se o MMRI está adequado

para o registro das respostas às perguntas formuladas quanto à

rede de suporte social do idoso.

Com relação à adequação do MMRI, dê uma nota de 1 a 5: (1 - total discordância; 5 - total concordância)

Resposta: Nota:

Sugestões:

Observações: 


\section{ANEXO 5 \\ 1a CARTA CONVITE}

Prezado(a) Colega.

A permanência do idoso na comunidade, desenvolvendo suas atividades cotidianas e exercendo sua cidadania, é a diretriz precipua da Política Nacional do Idoso. Em algumas circunstâncias, contudo, ele pode vir a requisitar o auxílio das pessoas do seu rol de relacionamentos. Segundo Néri (2001) e Sluzki (1997), este conjunto de indivíduos é denominado de Rede de Suporte Social.

A identificação dessa rede de relações, portanto, é de extrema importância para que possamos dar-Ihe visibilidade, valorizando-a e mobilizando-a, efetivando, dessa maneira, a parceria entre o apoio informal, provindo desses relacionamentos, e o formal, constituído pelos profissionais que atuam com o idoso.

Sendo assim, gostaria de contar com a sua colaboração como um juiz para o pré-teste dessa pesquisa. Sua participação implica avaliar um instrumento para identificar a Rede de Suporte de Relações do Idoso, que pretendo validar.

\section{Sobre o Mapa Mínimo de Relações}

O Mapa Mínimo de Relações foi formulado por Carlos Sluzki, médico psiquiatra, argentino, radicado nos Estados Unidos. Ele dirige uma instituição para doentes mentais na Califórnia e trabalha com um enfoque de teoria e terapia sistêmica, formulando esse instrumento para utilização com essa clientela. Cabe ainda esclarecer que o instrumento original não é validado no idioma em que foi concebido, o espanhol, e que sua tradução para o português deu-se por meio de um livro publicado em 1997, com a anuência do autor.

Com a permissão do Professor Sluzki, em minha dissertação de mestrado, também na Faculdade de Saúde Pública da USP, em 2000, adaptei o instrumento para a utilização com idosos.

Neste estudo pretendo validar o MMRI para a avaliação da rede de suporte social dos idosos em nosso meio sociocultural, verificando também sua confiabilidade.

\section{Sobre o método de validação a ser utilizado}

Para a validação de conteúdo do MMRI utilizarei a técnica Delfos, que busca o consenso sobre as questões formuladas em um dado instrumento (Spínola 1984). Tal 
consenso é obtido submetendo o instrumento à análise de especialistas, denominados de "juízes".

\section{Sobre as etapas da pesquisa}

Enviarei o instrumento ao senhor(a) simultaneamente por meio eletrônico e pelo correio, com envelope já selado para a resposta, sendo o prazo para devolução em ambos os casos de 10 dias.

A partir do recebimento do instrumento com seu julgamento, elaborarei um novo questionário com as questões consensuais. Considerarei consenso o índice $70 \%$ ou mais de aprovação para cada questão.

O novo questionário produzido será então novamente enviado, e nele explicitarei as médias obtidas em cada questão e a sua posição frente a cada pergunta.

O Instrumento que the enviarei compõe-se de:

- 4 (quatro) perguntas relativas à identificação do pesquisado;

- 4 (quatro) perguntas acerca das funções desempenhadas pelos integrantes da rede de suporte social do idoso;

- 1 (uma) pergunta quanto à apresentação gráfica do instrumento;

- mapa mínimo de relações, onde as respostas deverão ser registradas;

- instrutivo para o registro das respostas no MMRI.

Conto com sua participação para que tenhamos um instrumento que possa ser utilizado por profissionais da área da gerontologia, otimizando nossa avaliação e intervenção.

Antecipadamente agradeço sua valiosa colaboração, colocando-me à disposição para outros esclarecimentos que se façam necessários.

Atenciosamente,

\section{Marisa Accioly Domingues}

Aluna de Pós-Graduação, nivel doutorado, da Faculdade de Saúde Pública da USP Assistente Social, CRESS N. 13.584

Fone: $0 \times x 11) 9219-3501$

(0xx11) 3022-6897 


\title{
ANEXO 6 \\ TERMO DE CONSENTIMENTO LIVRE E ESCLARECIDO
}

Gostaria de convidá-lo(a) para participar da pesquisa que estou realizando na Faculdade de Saúde Pública da USP, como parte das exigências para obtenção do título de Doutora em Saúde Pública.

A pesquisa que realizarei tem por objetivo validar um instrumento que avalia a Rede de Suporte Social do Idoso, utilizando um instrumento gráfico, denominado de Mapa Mínimo de Relações do Idoso (MMRI).

A técnica que utilizarei para validar o instrumento é a Técnica Delfos, que consiste em buscar o consenso sobre as questões formuladas, submetendo-o à análise de especialistas, denominados de juizes.

Sua participação consiste em responder às questões relativas ao instrumento e devolvê-lo pelo correio ou por meio eletrônico.

Tratando-se de um trabalho acadêmico, o mesmo não é confidencial sendo, porém garantido o anonimato dos integrantes do estudo.

Caso o(a) sr.(a) decida participar, peço que assine o presente termo.

Atenciosamente,

\author{
Marisa Accioly Domingues \\ Assistente Social \\ CRESS 13.584 \\ Fone: $(0 \times x 11)$ 3022-6897 \\ (0x<11) 9219-3501
}

Nome:

Assinatura:

São Paulo, 


\begin{abstract}
ANEXO 7
PRIMEIRO QUESTIONÁRIO DELFOS DO MMRI
\end{abstract}

MAPA MÍNIMO DE RELAÇõES DO IDOSO (MMRI)

1) DADOS DE IDENTIFICAÇÃO

Data da entrevista: ................................

Nome:

Idade:

Endereço:

Fone:

2) MMRI

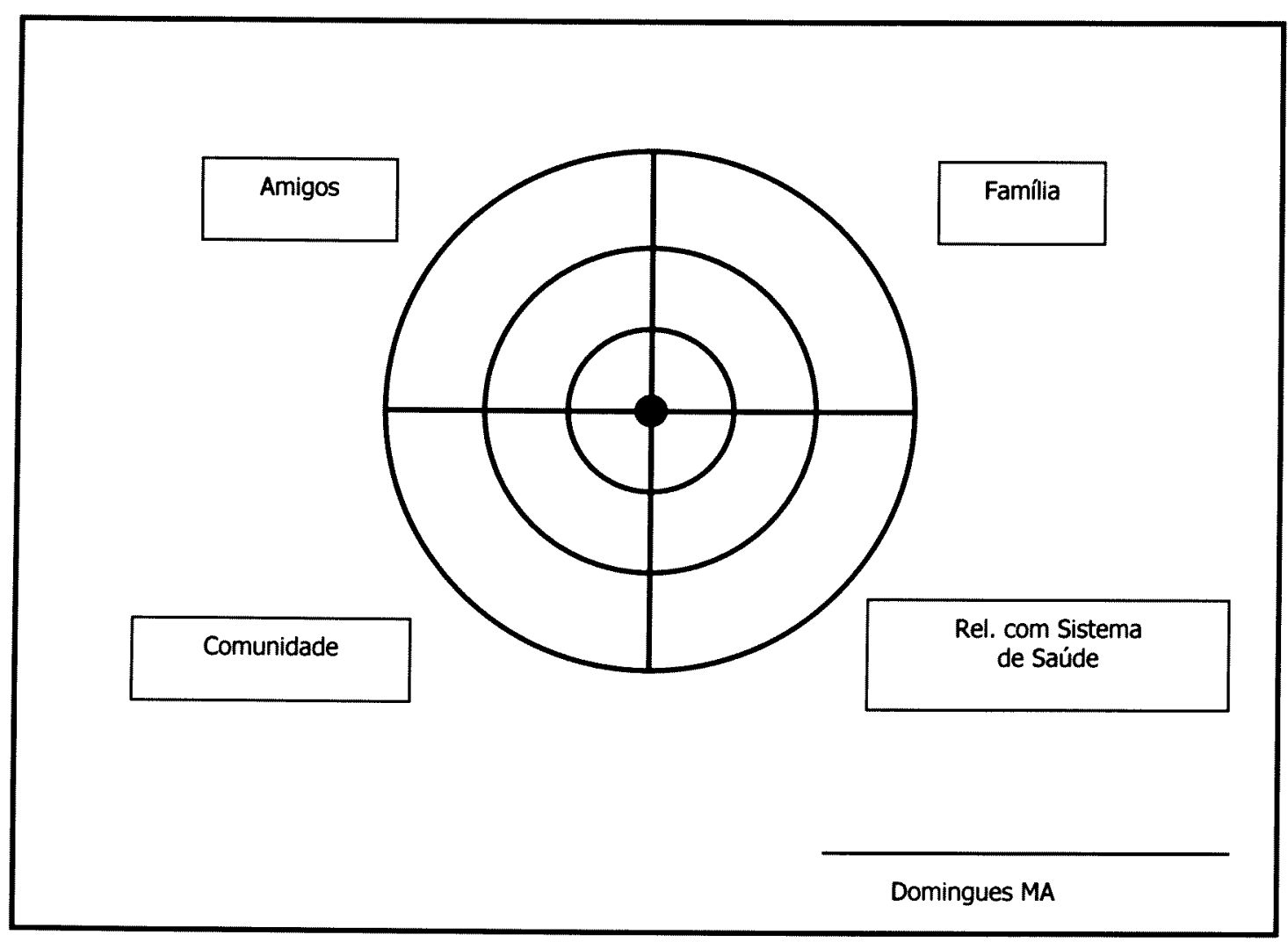




\section{INSTRUÇõES}

Formulam-se ao pesquisado, identificado pelo círculo escuro no centro no Mapa Mínimo, as seguintes perguntas:

1) Quem o(a) visita ou the faz companhia?

2) Se o(a) senhor(a) precisar de ajuda para serviços em sua casa, quem o(a) auxiliaria?

3) Se o(a) senhor(a) precisar de alguém para auxiliá-lo(a) em cuidados pessoais, quem o(a) auxiliaria?

4) Se o(a) senhor(a) precisar de auxílio financeiro, a quem o(a) senhor(a) recorreria?

Explica-se ao pesquisado, antes do início da entrevista, que cada pergunta conta com três possibilidades de respostas, correspondendo cada uma delas a uma proximidade de relacionamento. Deve-se ainda esclarecer que, se existir mais de uma pessoa, com a mesma proximidade, ele deve mencioná-la agregando a conjunção " $e$ ".

O registro das respostas será realizado da seguinte forma: pelo número da pergunta formulada $\mathrm{e}$ a sigla correspondente aos quadrantes relativos à "família" e à "comunidade". Nos quadrantes relativos a amigos e relações com sistema de saúde, registra-se a resposta também pelo número da pergunta e um ponto • , que significa uma pessoa mencionada.

A pausa realizada entre uma pessoa citada e outra significa a inclusão da última, em um círculo mais distante. Dessa maneira as respostas serão assim registradas:

$>$ a primeira resposta maior proximidade de relacionamento, correspondendo ao círculo interno;

a segunda significa relação intermediária, correspondendo ao círculo intermediário;

$>$ a terceira relação distante, sendo registrada no círculo externo.

Exemplo:

Pergunta que identifica a função de número 1 - Quem Ihe faz companhia?

Resposta: minha filha e meu irmão, pausa, minha vizinha, pausa, minha amiga.

Registro no Mapa Mínimo: no primeiro círculo, registra-se o número 1 e ao lado as siglas fa e io (abreviação de filha e irmão).

No segundo círculo, registra-se no quadrante de relações com a comunidade o número 1 e a abreviação vi (abreviação de vizinho).

No terceiro círculo registra-se no quadrante de relações com amigos o número 1 e •.

Assim procedemos com as demais perguntas.

O tamanho da Rede de suporte social corresponde, dessa maneira, ao número de registros no Mapa mínimo de relações, segundo a percepção do idoso. Além do tamanho, esse instrumento nos permite conhecer a média e a amplitude dos relacionamentos por quadrante, ou seja, pela composição, por círculo (proximidade de relacionamento) e por função (símbolo e abreviações) das relações significativas mencionadas.

1 - companhia

2 - auxillo para atividades domésticas

3 - auxilio para cuidados pessoais

4 - auxilio financeiro $1^{\text {a }}$ Resposta $=1^{\circ}$ Círculo $\supset$ Relacionamento Próximo

$2^{\mathrm{a}}$ Resposta $=2^{\circ}$ Círculo $\diamond$ Relacionamento Intermediário

$3^{\text {a }}$ Resposta $=3^{\circ}$ Círculo $\curvearrowright$ Relacionamento Distante 
REGISTRO DAS RESPOSTAS

\begin{tabular}{cll}
\hline $\begin{array}{c}\text { Amigos e Sistema } \\
\text { de Saúde }\end{array}$ & Família & Comunidade \\
\hline$\bullet$ & eo - esposo & $\mathrm{cc}$ - membros de centro de convivência \\
ea - esposa & $\mathrm{cl}$ - membros de clubes de lazer ou serviço \\
fa - filha & $\mathrm{gr}$ - membros de grupos religiosos \\
fo - filho & gt - membros de grupos de terceira idade \\
io - irmão & ps - prestadores de serviços \\
ia - irmã & vi - vizinhos \\
na - neta & \\
no - neto & \\
o- outros & 0 - outros \\
\hline
\end{tabular}

\section{QUESTIONÁRIO DELFOS}

As perguntas relativas aos dados de identificação estão apresentadas de forma bastante sucinta. Com relação à sua clareza, dê uma nota de 1 a 5: (1 - total discordância; 5 - total concordância). Resposta: Nota:

Sugestões:

Observações:

Com relação à pertinência das perguntas, dê uma nota de 1 a $5:$ ( 1 - total discordância; 5 - total concordância)

Resposta: Nota:

Sugestões:

Observações: 


\section{PERGUNTAS RELATIVAS AO MMRI}

1) QUEM O(A) VISITA OU LHE FAZ COMPANHIA?

Com esta pergunta procuramos identificar as pessoas que o idoso inclui no seu círculo de relações

Com relação à clareza do enunciado, dê uma nota de 1 a 5: (1 - total discordância; 5 - total concordância)

Resposta: Nota:

Sugestões:

Observações:

Com relação à pertinência da pergunta, dê uma nota de 1 a 5: (1 - total discordância; 5 - total concordância)

Resposta: Nota:

Sugestões:

Observações:

Com relação à forma de registro da resposta no Mapa Mínimo, dê uma nota de 1 a 5: (1- total discordância; 5 - total concordância)

Resposta: Nota:

Sugestões: 
Observações:

2) SE O(A) SENHOR(A) PRECISAR DE AUXÍLIO PARA SERVIÇOS DOMÉSTICOS, QUEM O(A) AUXILIARIA?

Com esta pergunta procuramos identificar as pessoas que o idoso inclui no seu círculo de relações e que podem auxiliá-lo nas tarefas domésticas como: arrumar a casa, lavar a louça e até mesmo fazer as compras.

Com relação à clareza do enunciado, dê uma nota de 1 a 5 : (1 - total discordância; 5 - total concordância)

Resposta: Nota:

Sugestões:

Observações:

Com relação à pertinência da pergunta, dê uma nota de 1 a $5:$ : 1 - total discordância; 5 - total concordância)

Resposta: Nota:

Sugestões:

\section{Observações:}

Com relação à forma de registro da resposta no Mapa Mínimo, dê uma nota de 1 a 5: (1 - total discordância; 5 - total concordância)

Resposta: Nota: 
Sugestões:

Observações:

3) SE O(A) SENHOR(A) PRECISAR DE AUXÍLIO PARA CUIDADOS PESSOAIS, QUEM O(A) AUXILIARIA?

Com esta pergunta procuramos identificar as pessoas que o idoso inclui no seu círculo de relações disponíveis para auxiliá-lo nos cuidados pessoais tais como: higiene, alimentação e outros.

Com relação à clareza do enunciado, dê uma nota de 1 a 5: (1 - total discordância; 5 - total concordância)

Resposta: Nota:

Sugestões:

Observações:

Com relação à pertinência da pergunta, dê uma nota de 1 a 5 : (1 - total discordância; 5 - total concordância)

Resposta: Nota:

Sugestões: 
Observações:

Com relação à forma de registro da resposta no Mapa Mínimo, dê uma nota de 1 a 5: (1 - total discordância; 5 - total concordância)

Resposta: Nota:

Sugestões:

Observações:

4) SE O(A) SENHOR(A) PRECISAR DE AUXÍLIO FINANCEIRO QUEM O(A) AUXILIARIA?

Com esta pergunta procuramos identificar as pessoas do circulo de

relações do idoso, que estão disponiveis e possuem condições de

auxiliá-lo financeiramente.

Com relação à clareza do enunciado, dê uma nota de 1 a 5: (1 - total discordância; 5 - total concordância)

Resposta: Nota:

Sugestões:

Observações:

Com relação à pertinência da pergunta, dê uma nota de 1 a 5: (1 - total discordância; 5 - total concordância)

Resposta: Nota: 
Sugestões:

Observações:

Com relação à forma de registro da resposta no Mapa Mínimo, dê uma nota de 1 a 5: (1 - total discordância; 5 - total concordância)

Resposta: Nota:

Sugestões:

Observações:

5) QUANTO À APRESENTAÇÃO GRÁFICA DO INSTRUMENTO, DÊ UMA NOTA DE 1 A 5.

Com esta pergunta procuramos saber se o MMRI está adequado para o registro das respostas às perguntas formuladas quanto à rede de suporte social do idoso.

Com relação à adequação do MMRI dê uma nota de 1 a 5 : (1 - total discordância; 5 - total concordância)

Resposta: Nota:

Sugestões:

Observações: 


\section{ANEXO 8 \\ 2a CARTA CONVITE}

São Paulo, 18 de janeiro de 2004

Caro juiz!

Envio para a sua apreciação e avaliação o $2^{\circ}$ questionário Delfos.

A elaboração do $2^{\circ}$ instrumento foi realizada após a análise dos dados do $1^{\circ}$ questionário, sendo mantidas as questões que obtiveram pelo menos $70 \%$ de concordância entre os especialistas.

Com o objetivo de compartilhar ainda mais a pesquisa entre os avaliadores, remeto a tabulação de dados referente à análise do $1^{\circ}$ instrumento, Mapa Mínimo de Relações do Idoso (MMRI), e as sugestões e observações dos demais juízes, destacando a sua posição (anexo 1).

Para preservar o sigilo, adotei, para identificá-los, o nome de pedras preciosas. Julguei ser mais interativo e afetuoso, em vez de números, cores ou letras do nosso alfabeto, por exemplo.

Você é para mim, portanto, uma preciosidade.

Continuo contando com a sua participação nesta segunda etapa de pesquisa.

Para tanto, solicito a gentileza de me enviar, por este e-mail, ou se preferir no endereço postal abaixo, o $2^{\circ}$ instrumento preenchido e analisado, no prazo de 15 dias - 29 de janeiro de 2004.

Mais uma vez agradeço sua valiosa colaboração.

Um abraço,

Marisa

\section{Marisa Accioly Domingues}

Aluna de Pós-Graduação, nivel doutorado, da Faculdade de Saúde Pública da USP.

Assistente Social - CRESS N. 13.584

Meus contatos: Fone: (11) 3022-6897 (res.) - (11) 9219-3501

End.: Rua Pio XI, 1481/31, bairro: Alto de Pinheiros

CEP: 05468-140 São Paulo/SP 
ANEXO 9

SEGUNDO QUESTIONÁRIO DELFOS DO MMRI

MAPA MÍNIMO DE RELAÇõES DO IDOSO (MMRI)

1) DADOS DE IDENTIFICAÇÃO

Data da entrevista: ...........................

Nome:

Sexo: Fem. ( )

Mas. ( )

Data de nascimento: ........../. Idade:

Endereço:.

Bairro:

Fone:

1) Estado Conjugal:

Solteiro(a) ( )

Casado(a) ( )

Separado(a) ( )

Viúvo(a) ( )

Outros:

\section{3) Há quanto tempo mora neste local:} menos de um ano ( )

de 1 a 5 anos ( )

de 6 a 10 anos ( )

de 11 a 15 anos ( )

de 16 a 19 anos ( )

mais de vinte anos ( )

5)Tipo de moradia:

Casa ( )

Apartamento ( )

Outros:
2) Quanto à convivência:

Reside sozinho(a)

$\sin ()$

não ( )

Se não, com quem reside:

Companheiro(a) ( ) Filho(a) ( ) Neto(a) ( )

Outros, quem:

\section{4) Escolaridade:}

Sem escolaridade ( )

$10 \mathrm{grau}$ incompleto ( )

$1^{\circ}$ grau completo ( )

$2^{\circ} \mathrm{grau}$ incompleto ( )

$2^{\circ}$ grau completo ( )

Superior incompleto ( )

Superior completo ( )

6) Vinculação do imóvel:

Próprio ( )

Alugado ( )

Cedido ( )

Outros: 
2) MMRI

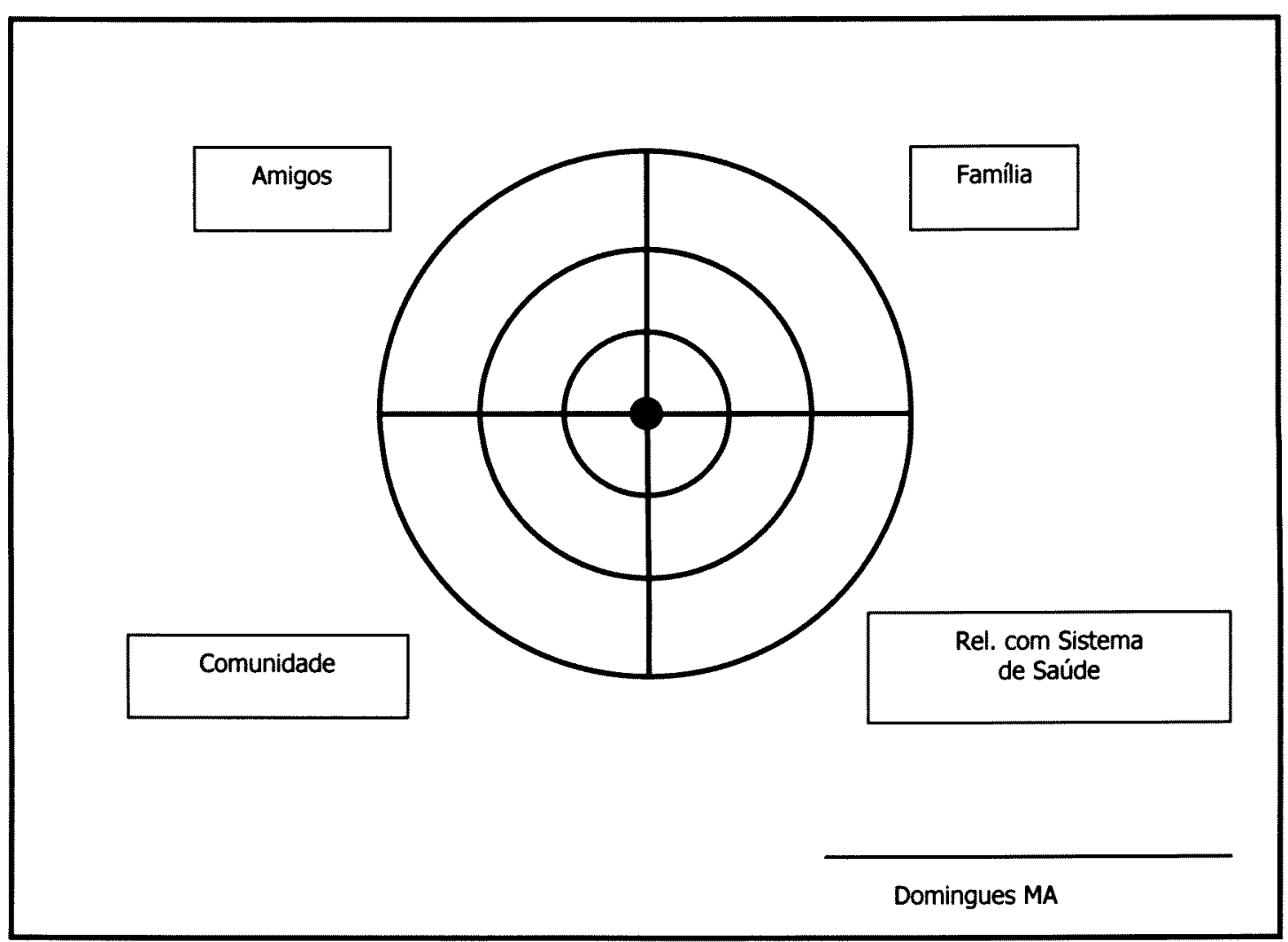

PERGUNTAS

1 - companhia

2 - auxilio para atividades domésticas

3 - auxilio para cuidados pessoals

4 - auxillo financeiro
PROXIMIDADE DE RELACIONAMENTO

PELO MENOS UMA VEZ POR SEMANA $=1^{\circ}$ Círculo $\curvearrowright$ Relacionamento Próximo PELO MENOS UMA VEZ POR MÊS $\quad=2^{\circ}$ Círculo $\curvearrowright$ Relacionamento Intermediário

PELO MENOS UMA VEZ POR ANO $=3^{\circ}$ Círculo $\curvearrowright$ Relacionamento Distante 
Abreviações/Símbolo utilizados para o registro das respostas

\begin{tabular}{cll}
\hline $\begin{array}{c}\text { Amigos e Sistema } \\
\text { de Saúde }\end{array}$ & Família & Comunidade \\
\hline$\bullet$ & eo - esposo & $\mathrm{cc}$ - membros de centro de convivência \\
& ea - esposa & $\mathrm{cl}$ - membros de clubes de lazer ou serviço \\
fa - filha & $\mathrm{gr}$ - membros de grupos religiosos \\
fo - filho & gt - membros de grupos de terceira idade \\
io - irmão & ps - prestadores de serviços \\
ia - irmã & vi - vizinhos \\
& na - neta & \\
no - neto & \\
& o- outros & o- outros \\
\hline
\end{tabular}

Observações:

\section{ESCLARECIMENTOS AO PESQUISADOR}

Antes do início da entrevista, mostra-se ao pesquisado o instrumento esclarecendo a sua localização no mapa, e como o mesmo será preenchido.

A proximidade de relacionamento, para fins do preenchimento do MMRI, é entendida segundo a percepção do idoso frente às pessoas do seu círculo de relacionamento.

O entrevistador deve estar atento para o caso de o idoso se referir à pessoa pelo nome ou apelido. Neste caso, deve perguntar: 0 que o senhor(a) é dele(a)? Após o esclarecimento do idoso(a), correlaciona-se o nome ou apelido a cada um dos quadrantes descritos no instrumento e então preenchesse o MMRI.

Para que o pesquisador não se perca no momento de registrar as respostas, recomenda-se que o faça no sentido horário iniciando pelo quadrante de relações com a família.

Foi previsto no instrumento, na página final, um espaço para observações do pesquisador, onde poderão ser registradas ou justificadas as respostas do(a) idoso(a) que forem necessárias. 


\section{INSTRUÇõES}

Formula-se ao(à) pesquisado(a), identificado(a) pelo círculo escuro no centro do MMRI, as seguintes perguntas:

1) Quais as pessoas que $o(a)$ visitam pelo menos:

- uma vez por semana?

- uma vez por mês?

- uma vez por ano?

2) A quem o senhor(a) recorre ou recorreria se precisar de alguém para Ihe fazer companhia. Com quem acha que pode contar pelo menos:

- uma vez por semana?

- uma vez por mês?

- uma vez por ano?

3) A quem o senhor(a) recorre ou recorreria se precisar de ajuda para cuidar das coisas da casa, como por exemplo: arrumar, limpar, cozinhar ou fazer compras. Com quem acha que pode contar pelo menos:

- uma vez por semana?

- uma vez por mês?

- uma vez por ano?

4) A quem o senhor (a) recorre ou recorreria se precisar de ajuda para coisas pessoais, como, por exemplo, trocar de roupa, tomar banho, comer, se levantar ou se deitar. Com quem acha que pode contar pelo menos:

- uma vez por semana?

- uma vez por mês?

- uma vez por ano?

5) A quem o senhor (a) recorre ou recorreria se precisar de auxílio para pagar uma conta, comprar um remédio ou para outras despesas da casa como com alimentação ou aluguel. Com quem acha que pode contar, pelo menos

- uma vez por semana?

- uma vez por mês?

- uma vez por ano? 
As respostas serão registradas no MMRI pelo número da pergunta formulada e as abreviações correspondentes aos quadrantes relativos à "família" e à "comunidade". Nos quadrantes relativos a amigos e relações com sistema de saúde/social, registra-se a resposta também pelo número da pergunta, e um ponto $(\bullet)$ que significa uma pessoa mencionada. 0 registro dessas respostas nos círculos, que identificam o grau de proximidade com o idoso, será realizado da seguinte forma:

Resposta do idoso: pelo menos uma vez por semana

Registro no MMRI: maior proximidade com o idoso, sendo a resposta registrada no $1^{\circ}$ círculo de proximidade

Resposta do idoso: pelo menos uma vez por mês

Registro no MMRI: proximidade intermediária com o idoso, sendo a resposta registrada no $2^{\circ}$ círculo de proximidade

Resposta do idoso: pelo menos uma vez por ano

Registro no MMRI: pouca proximidade com o idoso, sendo a resposta registrada no $3^{\circ}$ círculo de proximidade.

\section{EXEMPLO}

(Pergunta que identifica a função de número 1) Quais as pessoas que o(a) visitam pelo menos uma vez por semana?

Resposta: minha filha e meu irmão.

Registro no MMRI: o registro será realizado no primeiro círculo de proximidade com o número 1 (referente ao número da pergunta que identifica a função visita), ao lado das abreviações fa $\mathbf{e}$ io (abreviação de filha e irmão) e deverão ser registradas no quadrante de relações com a família.

Quais as pessoas que o(a) visitam pelo menos uma vez por mês?

Resposta: minha vizinha e uma amiga da minha igreja

Registro no MMRI: o registro será realizado no $2^{\circ}$ círculo de proximidade com o número 1 (referente ao número da pergunta que identifica a função visita) e a abreviação vi (vizinho) e gr (grupo religioso), no quadrante de relações com a comunidade.

Quais as pessoas que o(a) visitam pelo menos uma vez por ano?

Resposta: minha amiga, que mora em outra cidade e vem passar o natal aqui com os filhos e a irmã. 
Registro no MMRI: será no $3^{\circ}$ círculo de proximidade com o número 1 (referente ao número da pergunta que identifica a função visita) e um ponto $(\bullet)$ - símbolo de uma relação significativa no quadrante de amigos.

(Pergunta que identifica a função de número 2) Quem lhe faz companhia pelo menos uma vez por semana?

Resposta: O João, e uma moça que trabalha aqui em casa

Pergunta do pesquisador: E o João é o que seu?

Resposta do idoso(a): ele é meu marido

Registro no MMRI: 0 registro será realizado no $1^{\circ}$ ćrculo de proximidade com o número 2 (referente ao número da pergunta que identifica a função companhia) e a abreviação eo (esposo) no quadrante de família, e ps (prestador de serviço), no quadrante de relações com a comunidade.

Quem Ihe faz companhia pelo menos uma vez por mês?

Resposta: minha neta que mora em outra cidade e vem passar uns dias comigo. Sabe, eu sou irmã da mãe dela e a criei. Ela é como uma filha.

Registro no MMRI: 0 registro será realizado no $2^{\circ}$ círculo de proximidade com o número 2 (referente ao número da pergunta que identifica a função companhia) e a abreviação na (neta) no quadrante de familia.

Quem the faz companhia pelo menos uma vez por ano?

Resposta: São eles mesmos. Não tem mais ninguém, não senhora.

Registro no MMRI: Fica em branco, pois não tem nenhuma pessoa mencionada nessa categoria.

Quem the faz companhia pelo menos uma vez por mês?

Resposta: uma amiga que eu tenho há muitos anos.

No segundo círculo de proximidade registra-se o número da pergunta 2 e a abreviação (0), outros

Assim procedemos com as demais perguntas. 
O tamanho da Rede de Suporte Social corresponde, dessa maneira, ao número de registros no Mapa Mínimo de Relações, segundo a percepção do idoso. Além do tamanho, esse instrumento nos permite conhecer a média e a amplitude dos relacionamentos mencionados por quadrante, ou seja, pela composição (símbolo e abreviações), por círculo (freqüência de contatos) e por função desempenhada.

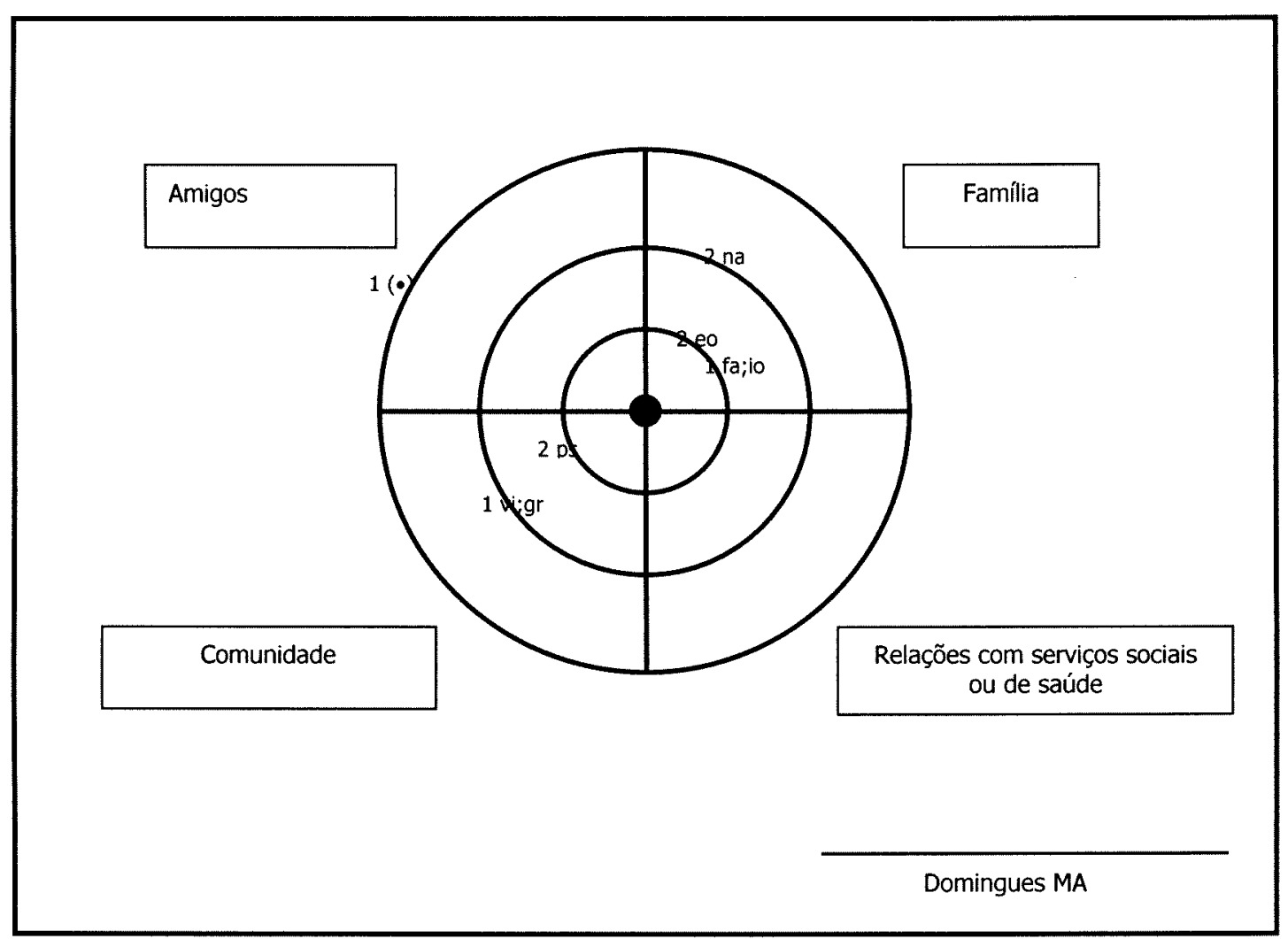




\section{SEGUNDO QUESTIONÁRIO DELFOS}

\section{PERGUNTAS RELATIVAS AOS DADOS DE IDENTIFICAÇÃO}

As perguntas relativas aos dados de identificação contemplam idade, data de nascimento, sexo, grau de instrução e outros, de modo que se possa consolidar uma base de dados sociofamiliares do(a) idoso(a).

Com relação à clareza das perguntas, dê uma nota de 1 a 5: (1 - total discordância; 5 - total concordância)

Resposta: Nota:

Sugestões:

Observações:

Com relação à pertinência das perguntas, dê uma nota de 1 a $5:$ ( 1 - total discordância; 5 - total concordância)

Resposta: Nota:

Sugestões:

\section{Observações:}




\section{PERGUNTAS RELATIVAS AO MMRI}

1) QUAIS AS PESSOAS QUE O(A) VISITAM PELO MENOS:

- uma vez por semana?

- uma vez por mês?

- e uma vez por ano?

Com esta pergunta procuramos identificar as pessoas que $o(a)$ idoso(a) inclui no seu círculo de relações, atribuindo a cada uma das alternativas, uma proximidade de relacionamento:

- pelo menos uma vez por semana: relação próxima para com o(a) idoso(a), resposta registrada no $1^{\circ}$ círculo de proximidade;

- pelo menos uma vez por mês: relação intermediária para com o (a) idoso(a), sendo a resposta registrada no ćrculo intermediário;

- pelo menos uma vez por ano: relação distante para com o(a) idoso(a), resposta registrada no $3^{\circ}$ círculo de proximidade.

Com relação à clareza do enunciado, dê uma nota de 1 a 5: (1 - total discordância; 5 - total concordância)

Resposta: Nota:

Sugestões:

Observações:

Com relação à forma de registro da resposta no Mapa Mínimo, dê uma nota de 1 a 5: (1 - total discordância; 5 - total concordância)

Resposta: Nota:

Sugestões: 
Observações:

2) A QUEM O SENHOR(A) RECORRE OU RECORRERIA SE PRECISAR DE ALGUÉM PARA LHE FAZER COMPANHIA? COM QUEM ACHA QUE PODE CONTAR PELO MENOS:

- uma vez por semana?

- uma vez por mês?

- e uma vez por ano?

Com esta pergunta procuramos identificar as pessoas que $o(a)$ idoso(a) inclui no seu círculo de relações, atribuindo a cada uma das alternativas, uma proximidade de relacionamento:

- pelo menos uma vez por semana: relação próxima para com o(a) idoso(a), resposta registrada no $1^{\circ}$ círculo de proximidade;

- pelo menos uma vez por mês: relação intermediária para com o (a) idoso(a), sendo a resposta registrada no ć́rculo intermediário;

- pelo menos uma vez por ano: relação distante para com o(a) idoso(a), resposta registrada no $3^{\circ}$ círculo de proximidade.

Com relação à clareza do enunciado, dê uma nota de 1 a 5: (1 - total discordância; 5 - total concordância)

Resposta: Nota:

Sugestões:

Observações:

Com relação à forma de registro da resposta no Mapa Mínimo, dê uma nota de 1 a 5: (1 - total discordância; 5 - total concordância)

Resposta: Nota: 
Sugestões:

Observações:

3) A QUEM O SENHOR(A) RECORRE OU RECORRERIA SE PRECISAR DE AJUDA PARA CUIDAR DAS COISAS DA CASA, COMO, POR EXEMPLO, ARRUMAR, LMPAR, COZINHAR OU FAZER COMPRAS? COM QUEM ACHA QUE PODE CONTAR, PELO MENOS:

- uma vez por semana?

- uma vez por mês?

- e uma vez por ano?

\footnotetext{
Com esta pergunta procuramos identificar as pessoas que o idoso inclui no seu círculo de relações e que podem auxiliá-lo nas tarefas domésticas como: arrumar a casa, lavar louça e até mesmo fazer comida ou compras, atribuindo, a cada uma das alternativas, uma proximidade de relacionamento:

- pelo menos uma vez por semana: relação próxima para com o(a) idoso(a), resposta registrada no $1^{\circ}$ círculo de proximidade;

- pelo menos uma vez por mês: relação intermediária para com o (a) idoso(a), sendo a resposta registrada no círculo intermediário;

- pelo menos uma vez por ano: relação distante para com o(a) idoso(a), resposta registrada no $3^{\circ}$ círculo de proximidade.
}

Com relação à clareza do enunciado, dê uma nota de 1 a 5: (1 - total discordância; 5 - total concordância)

Resposta: Nota:

Sugestões: 
Observações:

Com relação à forma de registro da resposta no Mapa Mínimo, dê uma nota de 1 a 5: (1 - total discordância; 5 - total concordância)

Resposta: Nota:

Sugestões:

Observações:

4) A QUEM O(A) SENHOR(A) RECORRE OU RECORRERIA SE PRECISAR DE AJUDA POR EXEMPLO PARA TROCAR DE ROUPA, TOMAR BANHO, COMER, SE LEVANTAR, SE DEITAR? COM QUE ACHA QUE PODE CONTAR, PELO MENOS:

- uma vez por semana?

- uma vez por mês?

- e uma vez por ano?

Com esta pergunta procuramos identificar as pessoas que o idoso inclui no seu círculo de relações disponiveis para auxiliá-lo nos cuidados pessoais tais como higiene pessoal e/ou outras atividades de autocuidado, atribuindo, a cada uma das alternativas, uma proximidade de relacionamento:

- pelo menos uma vez por semana: relação próxima para com o(a) idoso(a), resposta registrada no $1^{\circ}$ círculo de proximidade;

- pelo menos uma vez por mês: relação intermediária para com o(a) idoso(a), sendo a resposta registrada no círculo intermediário;

- pelo menos uma vez por ano: relação distante para com o(a) idoso(a), resposta registrada no $3^{\circ}$ círculo de proximidade. 
Com relação à clareza do enunciado, dê uma nota de 1 a 5: (1 - total discordância; 5 - total concordância)

Resposta: Nota:

Sugestões:

Observações:

Com relação à forma de registro da resposta no Mapa Mínimo, dê uma nota de 1 a 5: (1 - total discordância; 5 - total concordância)

Resposta: Nota:

Sugestões:

Observações:

5) A QUEM O(A) SENHOR(A) RECORRE OU RECORRERIA SE PRECISAR DE AUXÍLIO PARA PAGAR UMA CONTA, COMPRAR UM REMÉDIO OU PARA OUTRAS DESPESAS COMO, POR EXEMPLO, COM ALIMENTAÇÃO, OU ALUGUEL DA SUA CASA? COM QUEM ACHA QUE PODE CONTAR, PELO MENOS:

- uma vez por semana?

- uma vez por mês?

- e uma vez por ano? 
Com esta pergunta procuramos identificar as pessoas do círculo de relações do idoso que estão disponiveis e possuem condições de auxiliá-lo financeiramente em despesas com medicamentos ou outras, como as relativas à moradia, alimentação etc. atribuindo a cada uma das alternativas uma proximidade de relacionamento:

- pelo menos uma vez por semana: relação próxima para com o(a) idoso(a), resposta registrada no $1^{\circ}$ círculo de proximidade;

- pelo menos uma vez por mês: relação intermediária para com o(a) idoso(a), sendo a resposta registrada no círculo intermediário;

- pelo menos uma vez por ano: relação distante para com o(a) idoso(a), resposta registrada no $3^{\circ}$ círculo de proximidade.

Com relação à clareza do enunciado, dê uma nota de 1 a 5: (1 - total discordância; 5 - total concordância)

Resposta: Nota:

Sugestões:

Observações:

Com relação à forma de registro da resposta no Mapa Mínimo, dê uma nota de 1 a 5: (1 - total discordância; 5 - total concordância)

Resposta: Nota:

Sugestões:

Observações: 
6) QUANTO À APRESENTAÇÃO GRÁFICA DO INSTRUMENTO, DÊ UMA NOTA DE 1 A 5.

Com esta pergunta procuramos saber se o MMRI está adequado para o registro das respostas às perguntas formuladas quanto à rede de suporte social do idoso, contemplando a proximidade de relacionamento acordo de com as alternativas:

- pelo menos uma vez por semana: relação próxima para com o(a) idoso(a), resposta registrada no $1^{\circ}$ círculo de proximidade;

- pelo menos uma vez por mês: relação intermediária para com o(a) idoso(a), sendo a resposta registrada no círculo intermediário;

- pelo menos uma vez por ano: relação distante para com o(a) idoso(a), resposta registrada no $3^{\circ}$ círculo de proximidade.

Com relação à adequação do MMRI dê uma nota de 1 a 5 : (1 total discordância; 5 total concordância)

Resposta: Nota:

Sugestões:

Observações: 


\section{ANEXO 10}

\section{3a CARTA CONVITE}

São Paulo, 20 de março de 2004.

Caro Juiz!

Envio para a sua apreciação a pergunta de n $\mathbf{5}$ do Mapa Mínimo de Relações, que não obteve consenso total (nota 5) de 70\% dos juízes desta pesquisa.

Esta pergunta, da maneira como estava formulada, poderia dar uma conotação dúbia quanto o auxílio financeiro despendido e o auxílio instrumental para a sua execução.

Dessa maneira, reformulei a questão e a estou enviando para a sua apreciação. Nas demais questões, o consenso obtido foi superior ao estipulado e referendado por vários pesquisadores que utilizam a Técnica Delfos, que é de $70 \%$ de opiniões convergentes.

Quanto às suas sugestões de treinamento dos pesquisadores, reforçarei essa necessidade no corpo da tese.

Solicito mais uma vez sua valiosa contribuição para que eu possa concluir minha coleta de dados.

Seguem também anexas as tabulações dos dados, segundo a Escala de Lickert, e a análise do $2^{\circ}$ Instrumento - Questionário Delfos.

Assim que obtiver sua resposta, enviarei o questionário na sua versão final para a sua anuência e demais comentários.

Peço que me envie esta resposta, num prazo de quinze dias.

Mais uma vez agradeço a sua colaboração.

Um beijo carinhoso,

Marisa

Meus contatos:

Fone: (11) 3022-6897 (res.) - (11) 9219-3501

End: Rua Pio XI, 1481/31, bairro: Alto de Pinheiros

CEP: 05468-140 São Paulo/SP

e-mail: marisa_domingues@ig.com.br 


\section{TERCEIRO QUESTIONÁRIO DELFOS DO MMRI}

\section{Pergunta de nº 5 do Mapa Mínimo de Relações}

5) QUEM AJUDA OU AJUDARIA O(A) SENHOR(A) FINANCEIRAMENTE SE PRECISAR DE AUXÍLIO PARA PAGAR O ALUGUEL DA SUA CASA, PAGAR UMA CONTA, COMPRAR COMIDA, REMÉDIO ETC., PELO MENOS:

- uma vez por semana?

- uma vez por mês?

- e uma vez por ano?

Com esta pergunta procuramos identificar as pessoas do círculo de relações do idoso que estão disponíveis e possuem condições de auxiliá-lo financeiramente em despesas com medicamentos ou outros gastos, como os relativos à moradia, alimentação etc. atribuindo a cada uma das alternativas uma proximidade de relacionamento:

- pelo menos uma vez por semana: relação próxima para com o(a) idoso(a), resposta registrada no $1^{\circ}$ círculo de proximidade;

- pelo menos uma vez por mês: relação intermediária para com o(a) idoso(a), sendo a resposta registrada no círculo intermediário;

- pelo menos uma vez por ano: relação distante para com o(a) idoso(a), resposta registrada no $3^{\circ}$ círculo de proximidade.

Com relação à clareza do enunciado, dê uma nota de 1 a 5: (1 - total discordância; 5 - total concordância)

Resposta: Nota:

Sugestões:

Observações: 
Com relação à forma de registro da resposta no Mapa Mínimo, dê uma nota de 1 a 5: (1 - total discordância; 5 - total concordância)

Resposta: Nota:

Sugestões:

Observações: 


\section{CONSIDERAÇÕES E PARECER DO AUTOR DO MAPA MÍNIMO DE RELAÇÕES SOBRE O INSTRUMENTO FINAL}

Data: Tue, 27 Apr 2004 15:08:16 - 0400

De: csluzki@gmu.edū

Para: maccioly@usp.br

Assunto: MMRI instrument

Hola. colega.

Lamento el tiempo de demora en mi feedback (estuve viajando y ocupadisimo)

Sugerencias:

Pag. 1 de INSTRUMENTO DE COLECTA DE DADOS

Pon Escolaridade as \#2, ya que el resto se refiere a residencia.

En "Cedido", es suficientemente claro? Si no, talvez agregar, entre parentesis (propiedad de familiar otro).

Talvez valdria la mena de agregar otro item: (7) Nivel de confort: lugar confortable, espacio reducido, espacio minimo.

En p.3, INSTRUCOES, agregaroia, como item \#6; Con quem de todos estos o senhor(a) tiene una relacion de intimidad, como para hablar de cosas personales, de sentimientos, etc. (dejando abierta la posibilidad de que diga "con ninguno")

Espero que este comentario, que una vez mas lamento que no haya enviado antes, le sea de utilidad. El instrumento de por si es solido y util.

Un saludo cordial,

Carlos E. Sluzki, MD

Acting Dean for Health Science and Research College of Nursing and Health Science George Mason University 